\title{
ANÁLISE DAS BACIAS DA TRANSIÇÃO PROTEROZÓICO-FANEROZÓICO DO ESTADO DE SÃO PAULO E ADJACÊNCIAS
}

\author{
ANTONIO LUIZ TEIXEIRA
}

Orientador: Prof. Dr. Setembrino Petri

TESE DE DOUTORAMENTO

COMISSÃO JULGADORA

Nome

Presidente: Prof. Dr. Setembrino Petri

Examinadores: Prof. Dr. Claudio Gaucher

Prof. Dr. Claudio Riccomini

Prof. Dr. Paulo César Soares

Prof. Dr. Sidnei Pires Rostirolla

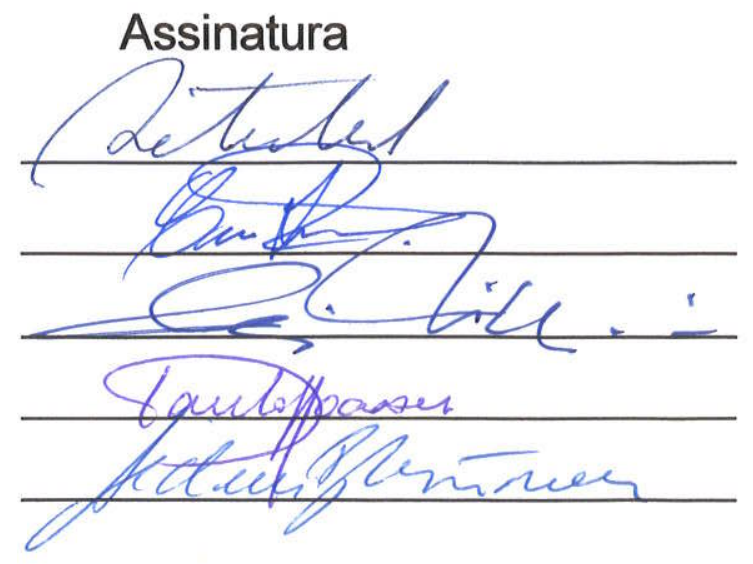

SÃO PAULO

2000 


\section{UNIVERSIDADE DE SÃO PAULO INSTITUTO DE GEOCIENCIAS}

\section{ANÁLISE DAS BACIAS DA TRANSIÇĀO PROTEROZÓICO-FANEROZÓICO DO ESTADO DE SÃO PAULO E ADJACÊNCIAS}

Antonio Luiz Teixeira

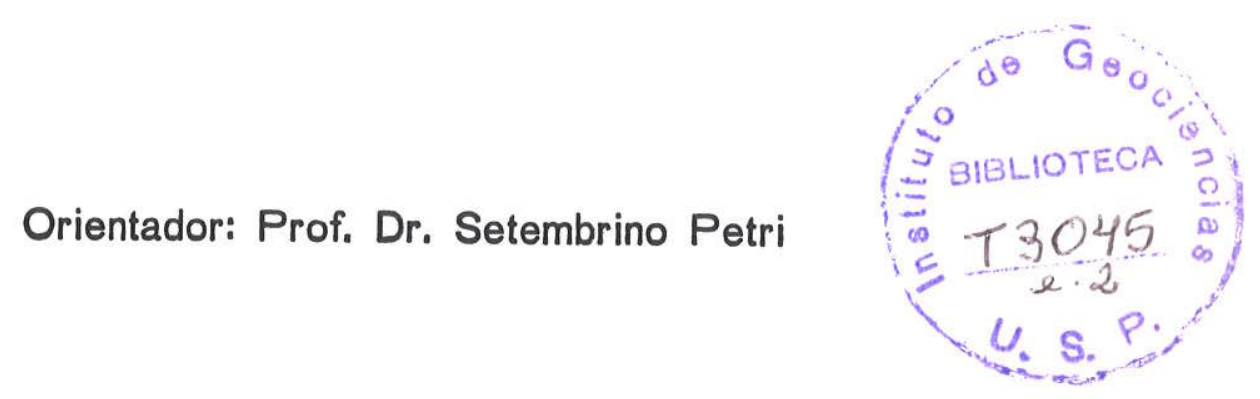

TESE DE DOUTORAMENTO

Programa de Pós-Graduação em Geologia Sedimentar

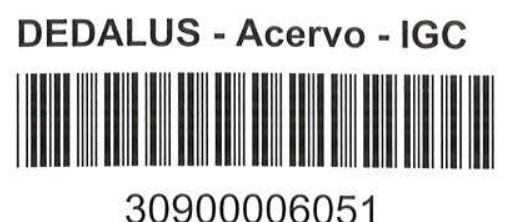

30900006051

SÃO PAULO

2000 
exas meus pais $\mathscr{Q}$

OAlos meus fithos 


\section{RESUMO}

As bacias eminentemente terrígenas situadas estratigraficamente acima dos orógenos e faixas móveis brasilianos e abaixo dos depósitos fanerozóicos da Bacia do Paraná, foram denominadas de bacias da transição Proterozóico-Fanerozóico. Ocorrem como pequenos corpos remanescentes da erosão fanerozóica, desde o sul do Estado de Minas Gerais, passando pelo Estado de São Paulo, até atingir a região metropolitana de Curitiba, capital do Estado do Paraná. Nesta ordem, são denominadas de: Bacia de Pouso Alegre (MG), bacias de Eleutério, do Pico de Itapeva, de Cajamar, do Quatis e do Samambaia (SP) e Bacia de Camarinha (PR). As suas exposições rochosas limitam-se aos domínios da Faixa de Dobramentos Ribeira, entidade geotectônica que atravessa os 3 estados com direção NE-SW, e constitui uma das principais suturas resultantes da amalgamação brasiliana do Gondwana Ocidental. Os limites atuais desses remanescentes de bacias são dados por falhamentos que constituem ramificações de zonas de cisalhamentos transcorrentes, característicos de toda a Faixa de Dobramentos Ribeira

O objetivo principal deste estudo consistiu em analisar as bacias da transição quanto às suas características litofaciológicas, estratigráficas, estruturais e tectônicas. Onde possível, isto ocorreu com o subsídio de análises geocronológicas, paleontológicas e litogeoquímicas. Os resultados obtidos apontaram a existência de grandes similaridades estratigráficas e estruturais entre elas, o que permitiu correlacioná-las e inferir que sua evolução se deu em um contexto paleogeográfico e paleotectônico comum.

A sedimentação teve início após o evento glacial Varanger (625-580 Ma), quando as condições no planeta eram de ascensão geral do nível dos oceanos e das temperaturas. A par disso, ocorria a abertura do Oceano Brazilides entre os crátons Amazônico/Pampeano e do São Francisco/Rio de la Plata/Paraná. Suas águas atingiam as porções meridionais do Bloco Paraná, penetrando nas regiões topograficamente mais baixas das faixas móveis e relativamente estabilizadas frente aos eventos orogenéticos, situadas nas porções ocidentais do Orógeno Mantiqueira. Essas águas vieram constituir o nível de base, marinho raso, para a sedimentação das bacias da transição que, geneticamente, associaram-se às movimentações laterais das zonas de cisalhamentos (strike slip basins).

A conexão entre os oceanos Brazilides e Adamastor ocorreu nas regiões entre o Bloco Paraná e o Cráton do Rio de la Plata, o que permitiu a ampla distribuição do microfóssil Cloudina riemkeae nas bacias do Nama (Namíbia), situada na borda ocidental do Cráton do 
Kalahari, do Arroyo del Soldado (Uruguai), situada na borda oriental do Cráton do Rio de la Plata, de Corumbá (MS), situada na borda oriental do Cráton Amazônico e, finalmente, nas bacias da transição em questão, situadas entre a borda oriental do Bloco Paraná e o Orógeno da Mantiqueira. Além da Cloudina, populações de acritarcas e do foraminífero Titanotheca coimbrae foram encontrados em algumas das bacias da transição e na Bacia do Arroyo del Soldado.

A inversão e encurtamento de todas essas bacias ocorreu graças ao fechamento dos oceanos Adamastor e Brazilides, iniciando a fase final de consolidação do Gondwana Ocidental. Nas bacias da transição, as assinaturas metamórficas desse fechamento estão refletidas nas idades $\mathrm{K}$-Ar de seixos riolíticos e nas idades $\mathrm{K}$-Ar de resfriamento da biotita de rochas do embasamento, correspondendo ao início da Orogenia Búzios/Cabo Frio (530-490 Ma), evento similar a outros, amplamente difundidos pelo continente sul-americano e africano. 


\section{ABSTRACT}

The eminently terrigenous basins, placed above the orogens and mobile belts of Braziliano age and below the phanerozoic deposits of the Paraná Basin, were denominated of Proterozoic-Phanerozoic Transition Basins. They happen as small remaining bodies of the erosion, from the south of the Minas Gerais State, going by the São Paulo State, until reaching the metropolitan area of Curitiba, Paraná State. In this order, they are denominated: Pouso Alegre (MG), Eleutério, Pico de Itapeva, Cajamar, Quatis and Samambaia (SP) and Camarinha (PR) basins. Their outcrops are limited to the domains of the Ribeira Folded Belt that crosses the 3 states with NE-SW direction, and it constitutes one of the main sutures resultants of the Braziliano Western Gondwana's amalgamation. The current limits of those remainders of basins are given by faults that constitute ramifications of wrench related zones, characteristic of the whole Ribeira Folded Belt.

The main purpose of this study consisted of analyzing these transition basins regarding their lithofacies, stratigraphic, structural and tectonic caracteristics. Where possible, this happened with the subsidy of isotopic, paleontological and lithochemical analyses. The obtained results have shown the existence of great stratigraphic and structural similarities among them, that allowed to correlate them and to infer that their evolution occurred in the same paleogeographic and paleotectonic context.

The sedimentation started after the glacial Varanger event $(625-580 \mathrm{Ma})$, when the conditions in the planet were of general ascension of the ocean levels and of the temperatures. At the same time, it happened the opening of the Brazilides Ocean among the Amazônico/Pampeano and São Francisco/Rio de la Plata/Paraná cratons. Its waters reached Paraná block's southern portions, penetrating in the lower areas in the mobile belt, relatively stabilized by the orogenic events, in the Mantiqueira Orogen western portions. Those waters came to constitute the shallow marine base level for the sedimentation in the transition basins, genetically associated to the lateral movements of the strike slip faults (strike slip basins).

The connection between the Brazilides and Adamastor oceans happened in the areas between the Parana block and the Rio de la Plata craton, that allowed the wide distribution of the microfossil Cloudina riemkeae in the basins of Nama (Namibia), placed in the western border of Kalahari craton; of Arroyo del Soldado (Uruguay), in the oriental border of the Rio de la Plata craton; of Corumbá (MS), oriental border of Amazônico craton; and, finally, in the 
basins of the transition in subject, located between Paraná block's oriental border and Mantiqueira Orogen. Besides Cloudina, acrytarchs populations and the Titanotheca coimbrae foraminifer were found in some of the transition basins and in the Arroyo del Soldado basin.

The inversion of all those basins happened with the closing of the Adamastor and Brazilides oceans, beginning the final phase of Western Gondwana consolidation. In the transition basins, the metamorphic signatures of that closing are reflected in the $K$-Ar ages of rhyolitic pebbles and in the $K-A r$ ages of cooling of the of basement rock's biotite, corresponding to the beginning of the Búzios/Cabo Frio Orogeny (530-490 Ma), similar event to other ones thoroughly diffused by the South American and African continent. 


\section{AGRADECIMENTOS}

Sem a contribuição das instituições e de várias pessoas esta pesquisa certamente não atingiria os resultados a que se chegou.

As instituições:

Primeiramente, agradeço o apoio do Instituto Geológico da Secretária do Meio Ambiente do Estado de São Paulo, instituição de cujos quadros funcionais faço parte, que incluiu o tema desta pesquisa em sua programação, além de ter dado todo o suporte administrativo e institucional.

A FAPESP, através dos processos 97/01013-4 e 99/12425-7, contribuiu com o apoio financeiro à pesquisa, sem o que seria inviável sua realização. Portanto, mais uma vez, à ela devemos nossos agradecimentos.

Ao Instituto de Geociências da USP, onde obtive quase toda minha formação profissional, os agradecimentos são, primeiramente, devidos ao Departamento de Geologia Sedimentar e Ambiental, no qual, junto ao Programa de Pós-Graduação em Geologia Sedimentar, este estudo foi desenvolvido. Aos demais departamentos dessa instituição, nossos agradecimentos pelo apoio formal ou informalmente prestado para a utilização de laboratórios e equipamentos.

As pessoas:

Começando pelos mais jovens, agradeço de coração a confiança depositada em mim pelo Prof. Setembrino Petri, orientando-me uma vez mais no mesmo programa pós-graduação, com aquela personalidade que lhe é peculiar: com ética profissional, espírito democrático, desprendimento e, ao mesmo tempo, com o rigor científico comparável ao mais rigoroso inverno. Professor, meu obrigado!

No Instituto Geológico vários colegas e amigos foram solidários. Devo meus agradecimentos ao pesquisador Francisco de Assis Negri com quem dividi várias das "preocupações geológicas" todo esse tempo, na mesma sala de trabalho, e pelo apoio em algumas das campanhas de campo. O colega José Maria de Azevedo Sobrinho contribuiu na descrição e interpretação de lâminas petrográficas e, evidentemente, nas cansativas revisões gramaticais e ortográficas de textos. $\mathrm{O}$ colega Hélio Shimada, exímio bateador, foi o responsável pela obtenção de concentrados de minerais pesados. Tarcísio José Montanheiro e Sílvio Takashi Hiruma, foram dois companheiros em algumas das viagens de campo, onde as discussões foram proveitosas; graças à singeleza e sinceridade desses amigos. O colega José Antônio Ferrari sempre me incentivou e, em algumas vezes, prestou seu valioso socorro nas questões de informática. Meus agradecimentos a todos esses colegas e amigos. À Sônia Aparecida Abissi Nogueira agradeço pela paciência e dedicação nos momentos mais difíceis e pela grande contribuição prestada na interpretação dos dados geoquímicos. Meus agradecimentos aos colegas do Geoprocessamento pelo suporte técnico prestado: ao Gilberto da Silva Sanchez, à Sandra das Graças Moni, à Rosângela Pereira de Carvalho e ao Paulo César de Lima Padilha. E, finalmente, agradeço aos colegas motoristas do IG, Márcio Félix Dionísio e José Roberto de Araújo, que participaram dedicadamente de, praticamente, todas as viagens ao campo.

No Instituto de Geociências da USP pude contar com o apoio de vários professores, colegas de pós-graduação e técnicos de laboratório.

Ao saudoso amigo e professor Armando Márcio Coimbra deveria agradecer pelo apoio e incentivo constantemente prestados.

Meus agradecimentos ao amigo e professor, Cláudio Riccomini, pelas várias oportunidades de discussões e reflexões sobre o tema desta tese. 
Do mesmo modo, meus agradecimentos ao amigo e professor Jorge Hachiro, pelo companheirismo e aguçada crítica emprestados durante o desenvolvimento desta pesquisa.

Em várias ocasiões tive o privilégio de contar com a atenção dos professores Sílvio Roberto Farias Vlach e Valdecir de Assis Janasi nas questões relacionadas com a geoquímica de rocha e seus métodos analíticos. O Prof. Gergely A. J. Szabó prestou imenso apoio para que fossem viabilizadas as análises de catodoluminescência em amostras de rochas carbonáticas. $\mathrm{O}$ amigo e professor Oswaldo Siga Jr. foi sempre colaborou na busca de alternativas de métodos de datações absolutas de metassedimentos. Sem o apoio do Prof. Umberto Gieuseppe Cordani as análises U/Pb, SHRIMP, de monocristais de zircão não teriam sido realizadas. O Prof. Mário da Costa Campos Neto contribuiu direta e indiretamente nas discussões e reflexões a respeito das modelagens paleotectônicas e paleogeográficas. A todos, meus sinceros agradecimentos.

O suporte laboratorial foi imprescindível. Meus agradecimentos ao Técnico José Paulo Sertek do Laboratório de Preparação de Amostras, pelos subsídios prestados na preparação de amostras para as análises geoquímicas. Do mesmo modo, o Técnico Flávio Machado de Souza Carvalho prestou inestimável auxílio na análise e interpretação de difratogramas de raios-X. As seções delgadas de amostras de rocha foram executadas com presteza e competência sob a responsabilidade do Técnico Claudio Hopp. Por sua vez, as análises com o microscópio eletrônico de varredura (MEV) só foram possíveis graças ao acompanhamento do Técnico Isaac Sayeg. A todos sou muito grato.

Ao amigo e pós-doutorando Victor Velásquez Fernandez agradeço pela contribuição nas discussões de campo e nas análises dos dados laboratoriais, que foram imprescindíveis para a caracterização de cinzas vulcânicas e para a interpretação de dados geoquímicos.

Aos colegas de pós-graduação Gélson Luís Fambrini e Renata de Paula Xavier Moro meus agradecimentos pelas discussões durante as viagens de campo e pelo incentivo.

E, finalmente, deixo aqui expressos meus agradecimentos aos profs. Claudio Gaucher e Peter Sprechmann, da Universidad de la República de Montevidéo, pelas análises micropaleontológicas realizadas e pelas discussões de campo. Além destes, meus sinceros agradecimentos ao amigo e ex-colega de pós-graduação, Prof. Paulo César Boggiani, da Universidade Federal do Mato Grosso do Sul, pelo apoio, incentivo e solidariedade dispensados.

Como se vê, o maior aprendizado foi, talvez, o de que o próprio aprendizado ocorre no bojo de um processo eminentemente coletivo, mesmo que, às vezes, sintamo-nos profundamente solitários. 


\section{SUMÁRIO}

DEDICATÓRIA. $i$

RESUMO ii

ABSTRACT iv

AGRADECIMENTOS $v i$

SUMÁRIO viii

1. INTRODUÇÃO. 1

1.1. Área dos Estudos. 2

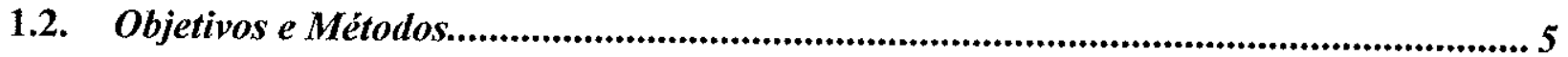

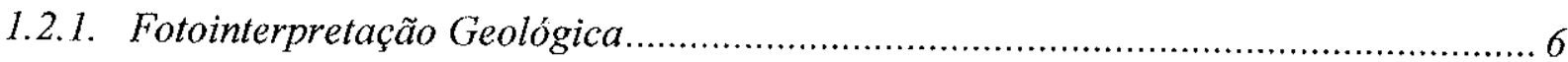

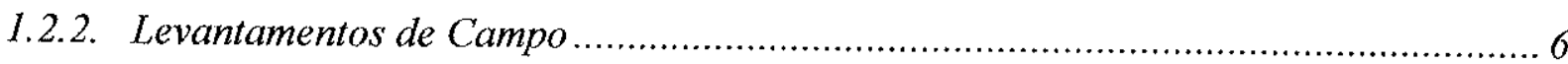

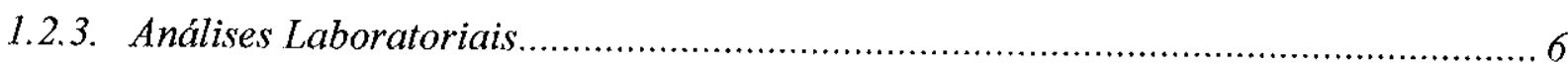

2. SÍNTESE DOS CONHECIMENTOS ANTERIORES.................................................

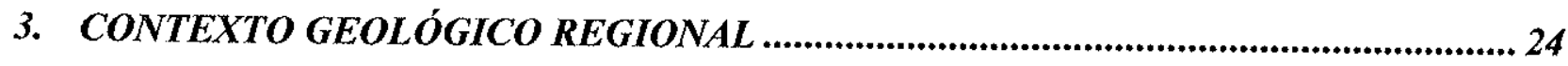

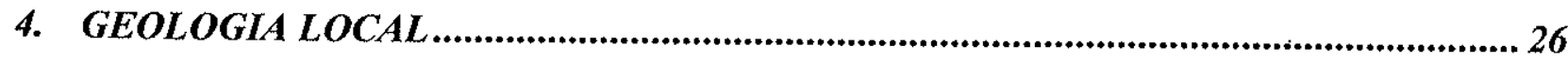

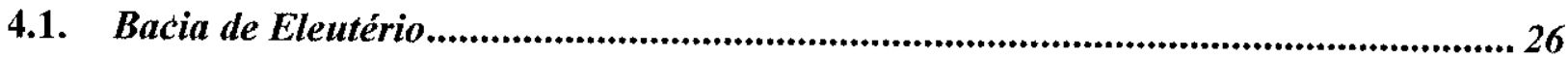

4.1.1. Associações de fácies da planície aluvial noroeste (A) ....................................... 28

4.1.1.1. Associação de fácies $A_{l}$ : metarenitos conglomeráticos arcoseanos ............... 28

4.1.1.2. Associação de fácies $A_{2}$ : metarenitos arcoseanos com base conglomerática 30

4.1.1.3. Associação de fácies $A_{3}$ : metarenitos arcoseanos com intercalações metapelíticas (transicionais a ambiente marinho raso) ............................................. 31

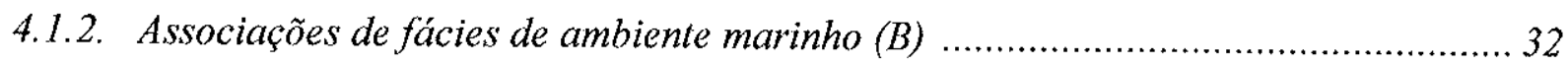

4.1.2.1. Associação de fácies $B_{1}$ : metarritmitos areno-silto-argilosos ........................ 32

4.1.2.2. Associação de fácies $B_{2}$ : metalaminitos silto-argilosos ............................... 32

4.1.3. Associações de fácies tectonicamente imbricadas ao longo da borda sudeste (C) ... 37

4.1.4. Associações de fácies do sistema de leques aluviais da borda sudeste (D) ............. 38

4.1.5. Associações de fácies em ocorrências isoladas (I) .............................................. 39

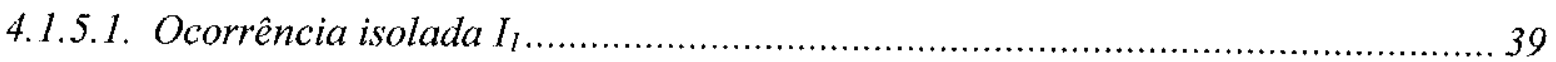




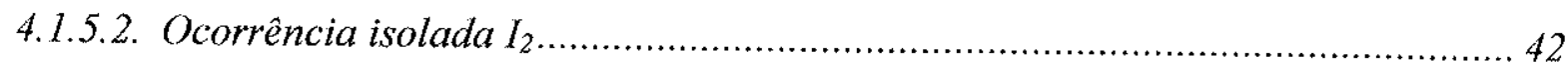

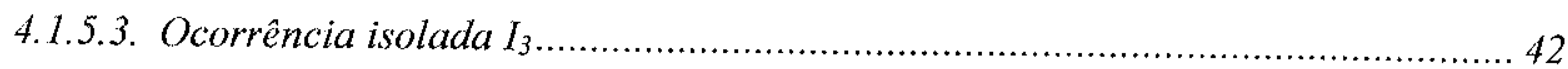

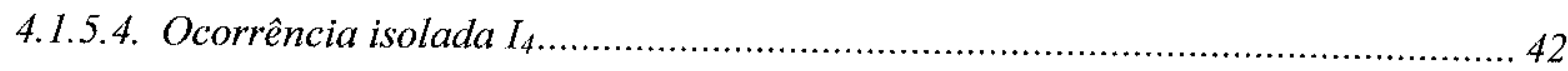

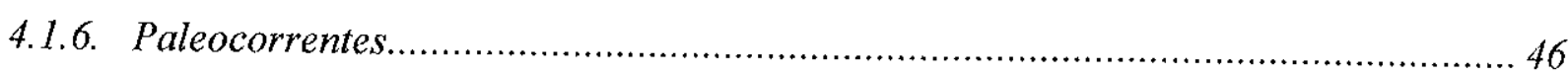

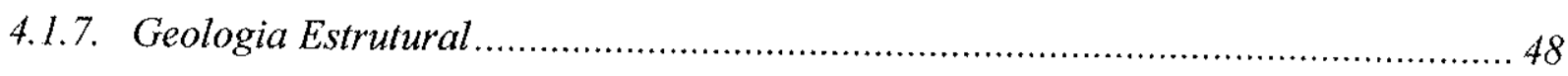

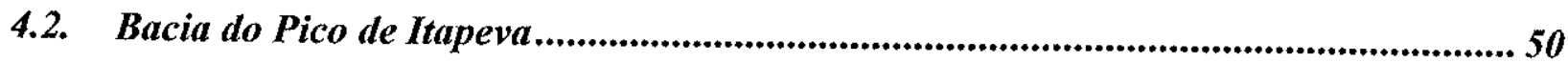

4.2.1. Metarritmitos com metaconglomerados e metarenitos intercalados ........................ 50

4.2.2. Metarenitos feldspáticos e arcosianos com predomínio de estratificação

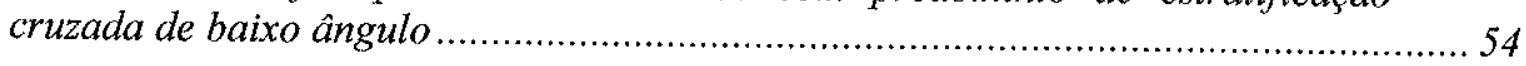

4.2.3. Metaconglomerados finos polimíticos.............................................................. 55

4.2.4. Metaconglomerados grossos polimíticos............................................................ 57

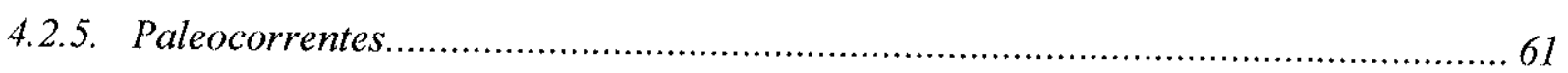

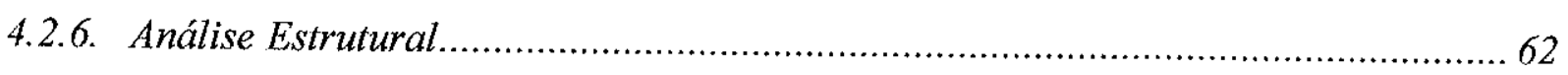

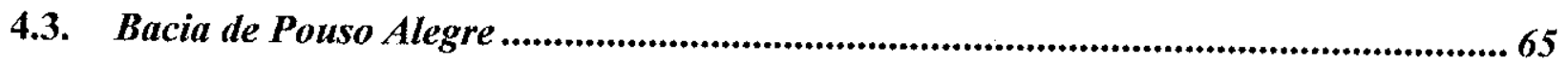

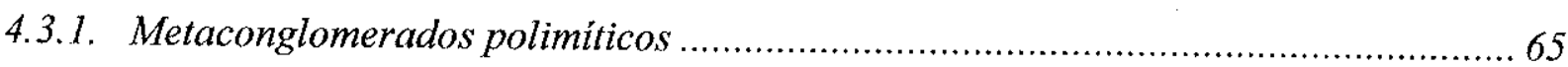

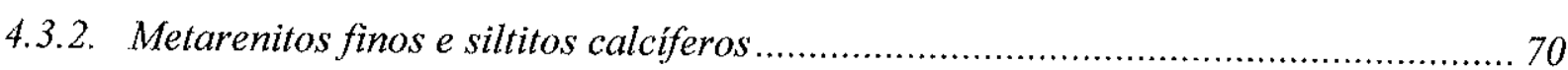

4.3.3. Metarenitos feldspáticos e arcoseanos com intercalações de conglomerados.......... 73

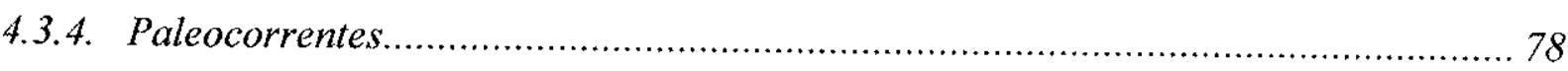

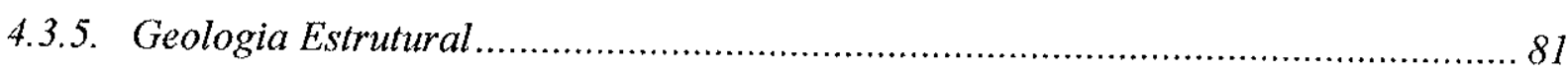

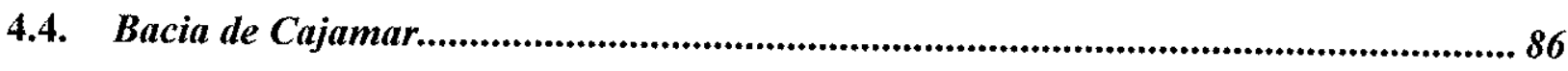

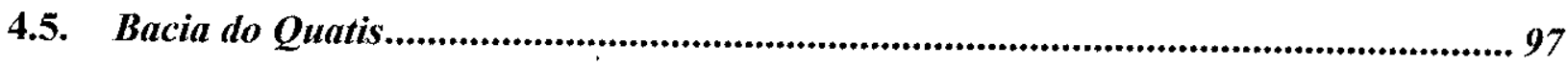

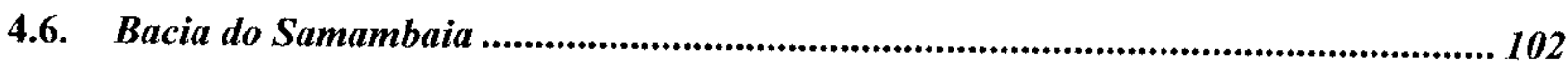

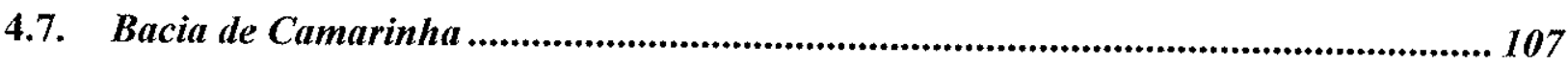

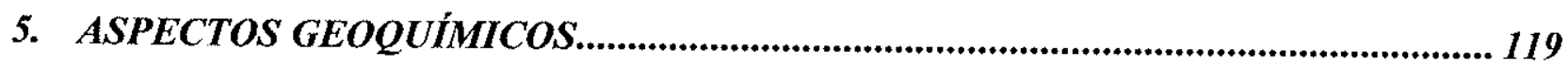

6. CORRELAÇÕES ENTRE AS BACIA DA TRANSIÇÃO ........................................... 135

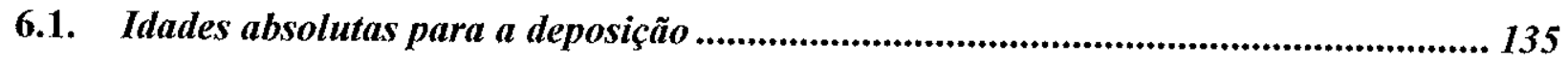

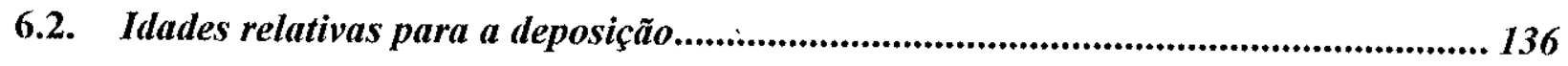

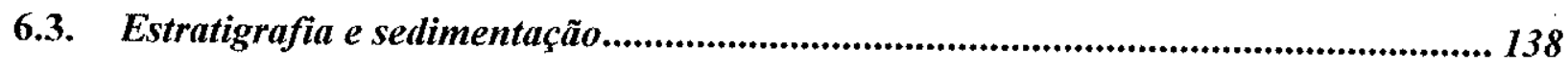

6.4. Evolução das bacias da transição no contexto do Gondwana Ocidental.................... 141

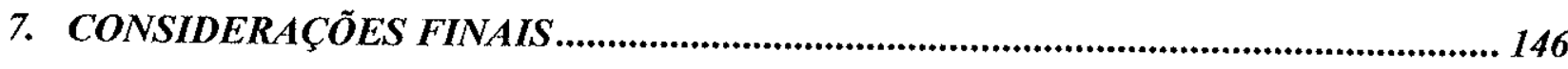


8. REFERÊNCIAS BIBLIOGRÁFICAS. 


\section{ÍNDICE DAS FIGURAS}

Figura 1.1.1 - Localização das bacias da transição Proterozóico-Fanerozóico do Estado de São Paulo e adjacências

Figura 3.l - Contexto geológico regional das bacias da transição ProterozóicoFanerozóico do Estado de São Paulo e adjacências.

Figura 4.1.1 - Mapa de associações de fácies e de traçados estruturais da Bacia de Eleutério.

Figura 4.1.2 - Metarenitos arcoseanos conglomeráticos e metarenitos grossos a finos (fácies $A_{1}$ )......

Figura 4.1.3 - Metarenito arcoseano de granulação média a grossa com intraclastos (Fácies $A_{2}$, flanco noroeste da Serra dos Machados, norte de Sapucaí)

Figura 4.1.4 - Seqüências gradacionais de metarenitos médios a grossos arcoseanos e metassiltitos (Fácies $A_{3}$, noroeste de Eleutério)

Figura 4.1.5 - Metarritmitos areno-silto-argilosos com ondulações cavalgantes (Fácies $B_{\text {, }}$ noroeste de Eleutério)

Figura 4.1.6 - Fotomicrografia: Gradação normal em laminito (fácies $B_{2}$, margem esquerda do Rio Eleutério), com foliação metamórfica incipiente

Figura 4.1.7 Amostra serrada de metalaminito da associação de fácies $B_{2}$, mostrando pseudo-concreções ferruginosas que se tratam de microfósseis Cloudina riemkeae. Ao fundo: detalhe microscópico do microfóssil.

Figura 4.1.8 - Seção colunar entre os pontos ET-50 e ET-52 das unidades $A_{3}$ e $B_{2}$ da Bacia de Eleutério

Figura 4.1 .9 - Grão de quartzo do tipo sprinter, presente em intercalações de cinzas vulcânicas em laminitos do ponto ET-50 (nivel $118 \mathrm{~m}$ do Perfil A, Figura 4.1.8)

Figura 4.1.10 - Cristal de zircão equigranular de intercalações laminadas em metalaminitos do ponto ET-50, nível $118 \mathrm{~m}$ do Perfil A, da Figura 4.1.8.

Figura 4.1.11 - Metalaminitos com intercalações de metarenitos grossos $e$ conglomeráticos com seixos de quartzitos milonitizados francamente angulosos (Fácies C, flanco noroeste da Serra dos Machados, norte do Bairro Sapucaí.

Figura 4.1.12 - Metaconglomerado polimítico clasto-sustentado com seixos e calhaus predominantemente de quartzitos milonitizados, tenuemente imbricados (fácies Dl, leste do Morro da Picura).

Figura 4.1.13 - Metaconglomerados com predomínio de seixos quartzo-feldspáticos milonitizados intercalados por metarenitos finos e metapelitos (Ocorrência $I_{l}$, margem esquerda do Rio Mogi-Guaçu, nordeste do Bairro São Luís)

Figura 4.1.14 - Metaconglomerado clasto-sustentado, constituído de cascalhos arredondados a subarredondados de riólitos (1), quartzitos róseos (2), metabasitos (3), leucogranitos (4), etc. (Ocorrência isolada $I_{4}$ )

Figura 4.1.15 - Fotomicrografia: Estrutura fluidal em seixo de rocha riolitica (Ocorrência isolada I4, próxima à Mogi Guaçu) 
Figura 4.1.16 - Resultados analiticos e diagrama concórdia U/Pb, obtidos pelo método SHRIMP em monocristais de zircão de seixo riolítico de metaconglomerado da Bacia de Eleutério

Figura 4.1.17-Paleocorrentes da Bacia de Eleutério.

Figura 4.1 .18 - Estereograma das atitudes do acamamento reliquiar $\left(S_{l}\right)$ e da clivagem ardosiana (So) obtidos a partir de medidas na Bacia de Eleutério

Figura 4.2.1 - Mapa litofaciológico da Bacia do Pico de Itapeva.

Figura 4.2.2 - Ritmitos de planície de marés ou de ambiente estuarino: pares sucessivos de siltitos argilosos cinza-escuro com arenitos muito finos cinza-claro, entremeados por arenitos mal selecionados marrom amarelados...

Figura 4.2 .3 - Passagem dos ritmitos para arenitos médios a finos com estratificações plano-horizontais e cruzadas de baixo ângulo, com estrutura de corte-epreenchimento na base destes envolvendo fragmentos de ritmitos.

Figura 4.2.4 - Metarenitos de granulação média a fina com estratificações cruzadas de baixo ângulo, prováveis estratificações cruzadas do tipo swaley e, talvez, hummockies

Figura 4.2.5 - Metaconglomerados finos polimiticos com estratificação cruzada planar de pequeno porte, com clastos (seixos) de granitóides ao longo dos foresets

Figura 4.2.6 - Metaconglomerado polimítico clasto-sustentado. Aspecto geral da rocha mostrando relações entre os clastos subarredondados, matacão de granitoide e foliação de cisalhamento predominantemente destrogiro, subvertical.

Figura 4.2.7 - Fotomicrografia: Detalhe da matriz do metaconglomerado do Pico de Itapeva

Figura 4.2.8 - Metaconglomerado clasto-sustentado com clasto de rocha metabásica intemperizado e com vazio ressaltando estrutura em forma de " $S$ ", compatível com deformação associada a binário destrogiro. (Ponto 01)

Figura 4.2.9- Coluna estratigráfica esquemática da Bacia do Pico de Itapeva

Figura 4.2.10-Diagrama de igual área para medidas do acamamento reliquiar $\left(S_{0}\right)$ e da foliação metamórfica $\left(S_{1}\right)$ da Bacia do Pico de Itapeva.

Figura 4.2.11 - Fotomicrografia: Matriz do metaconglomerado clasto-sustentado apresentando deformação destrogira em grão de K-feldspato

Figura 4.2.12 - Fotomicrografia: Corte vertical da mesma amostra da figura anterior, com observador a NE, onde se verifica a movimentação horária conferida pelas feições deformacionais dos feldspatos

Figura 4.3.1 - Mapa da distribuição das litofácies da Bacia de Pouso Alegre ......................... 66

Figura 4.3.2 - Detalhe dos metaconglomerados polimíticos clasto-sustentados

Figura 4.3.3 - Metaconglomerado polimítico clasto-sustentado organizado em tapetes de tração (traction carpets), com espessuras métrica a decimétrica

Figura 4.3.4 - Estrutura amendoada em metarenitos finos siltosos laminados, com $0,7 \mathrm{~m}$ de diametro, relacionada a ondas de tempestades (hummocky cross stratification.

Figura 4.3.5 - Metarenitos muito finos, com estratificação cruzada de pequeno porte, gradacionais ao topo para metassiltitos cinza e metargilitos cinza-escuro. 
Figura 4.3.6 - Fotomicrografia: Soldadophycus major GAUCHER 2000. Colônia de esferulitos poligonizados pela compressão mútua, com desenvolvimento de individuos filamentosos cilindricos.

Figura 4.3.7 - Fotomicrografia: Symplassosphaeridium sp. com colônia de esferóides poligonizados pela compressão mútua.

Figura 4.3.8 - Metarenitos médios a finos laminados com estratificação plano-horizontal a cruzada de baixo ângulo, associados a ambiente litorâneo de praia

Figura 4.3.9 - Metarenitos médios a finos laminados com estratificação plano-horizontal e cruzadas de baixíssimo ângulo, com lances (comprimento de onda) superiores aos $30 \mathrm{~m}$

Figura 4.3.10 - Metarenitos médios a finos, de dunas barcanóides, cinzelados por metaconglomerado polimítico clasto-sustentado, onde predominam clastos de milonitos.

Figura 4.3.11 - Metarenitos médios a finos laminados com estratificações cruzadas acanaladas de médio a grande portes, definindo dunas do tipo barcanóide

Figura 4.3.12 - Metaconglomerado polimitico com bloco de até $1 \mathrm{~m}$ de gnaisse bandado milonitico e outros da mesma rocha na granulometria calhaus e seixos.

Figura 4.3.13 - Truncamento com ângulo aparente de $45^{\circ}$ entre estratos de duna barcanóide

Figura 4.3.14 - Base de estrato de duna barcanóide, em bloco rolado e com topo invertido, com moldes de marcas onduladas assimétricas com cristas

Figura 4.3.15 -- Coluna estratigráfica esquemática da Bacia de Pouso Alegre

Figura 4.3.16-Análise das paleocorrentes obtidas para a Bacia de Pouso Alegre

Figura 4.3.17 - Diagrama de igual área para as projeções polares do acamamento $\left(S_{0}\right) e$ da clivagem ardosiana $\left(S_{l}\right)$ medidos na Bacia de Pouso Alegre.

Figura 4.3.18 - Metaconglomerados polimíticos com intercalações de metarenitos $e$ metassiltitos avermelhados cortados por planos escalonados de cisalhamento rúptil-dúctil com mergulhos para NW (Ponto 52)

Figura 4.3.19 - Fotomicrografia: Metassiltito arenoso calcífero apresentando feiçôes deformacionais que caracterizam movimentação anti-horária ao longo de planos de microfraturas (Ponto 15)

Figura 4.4.1 - Contexto geológico regional da Bacia de Cajamar (segundo Santoro et al. 1988)

Figura 4.4.2 - Geologia do sítio urbano de Cajamar e áreas de entorno(segundo Santoro et al. 1988)

Figura 4.4.3 - Perfil geológico entre os bairros Lavrinhas e Vila Santa Branca de Cajamar, segundo Hachiro \& Santoro (inédito)

Figura 4.4.4 - Diagrama de variações $\delta^{18} O_{S M O W} x \delta^{13} C_{P D B}$ (segundo Borscthevsky et al. 1981, apud Zahang 1988), com dados plotados de Frascá (1992) e deste projeto.

Figura 4.4.5 - Composição isotópica média de carbonatos marinhos e de água doce, tendo-se em conta as variações de $\delta^{13} C_{P D B}$ e $\delta^{18} O_{P D B}$ em função das idades geológicas (Keith \& Weber 1964). 
Figura 4.4.6 - Histogramas de variações $\delta^{13} C_{P D B}$ e $\delta^{18} O$ PDB para rochas carbonáticas versus a idade geológica, resultante da compilação de dados mundiais de Veizer \& Hoefs (1976)

Figura 4.4.7 - Fotomicrografia: Titanotheca coimbrae GAUCHER \& SPRECHMANN 1999 em metassiltito arenoso da Bacia de Cajamar. Amostra CJ-06

Figura 4.4.8 - Fotomicrografia: Titanotheca coimbrae GAUCHER \& SPRECHMANN 1999. Individuo jovem com forma mais esférica, apresentando, também, abertura silicosa substituida por silica microcristalina. Amostra CJ-06

Figura 4.5.1 - Contexto geológico regional das bacias do Samambaia, Quatis e Camarinha (segundo Campanha \& Sadowski 1999)

Figura 4.5.2 - Mapa litofaciológico da Bacia do Quatis, modificado de Campanha et al. (1985).

Figura 4.6.1 - Esboço geológico dos depósitos da Bacia do Samambaia (compilado e modificado de Campanha et al. 1988).

Figura 4.6.2 - Fotomicrografia: Detalhe da matriz de metaconglomerado polimítico da Bacia do Samambaia, ocupando apenas os interstícios entre grânulos de feldspatos, quartzo e intraclastos de metassiltitos.

Figura 4.7.1 - Esboço geológico da Bacia de Camarinha e seção geológica esquemática entre o Alto do Purunã e Taquaralzinho (compilado e modificado de Muratori et al. 1967)

Figura 4.7.2 - Metarenitos conglomeráticos com estratificação cruzada de pequeno porte. Ao longo dos foresets orientam-se seixos de granitóides $e$ de metassedimentos, além de intraclastos de siltitos argilosos marrom escuros. Ponto CA-OI.

Figura 4.7.3 - Marcas onduladas assimétricas com cristas sub-retilíneas a sublingüiformes geradas por processos de interferência de ondas, desenvolvidos sobre arenitos muito finos silto-argilosos. Ponto CA-OI

Figura 4.7.4 - Fotomicrografia: Matriz de conglomerado polimítico da Bacia de Camarinha predominantemente arenosa e mal selecionada, com grânulos intraclásticos de siltitos cimentados por óxidos/hidróxidos de $\mathrm{Fe} e$ extaclásticos. Amostra do ponto CA-07.

Figura 4.7.5 - Intercalação de arenitos mal selecionados e siltitos argilosos com estratificação cruzada planar de pequeno porte em conglomerados finos polimíticos clasto-sustentados. Ponto CA-06.

Figura 4.7.6 - Metaconglomerado polimítico clasto-sustentado com sucessivos "tapetes" com gradação normal, nos quais se destacam a imbricação de clastos e calhaus de rochas metabasiticas e de calciossilicatadas Ponto CA-02....

Figura 4.7.7 - Ritmitos areno-silto-argilosos com intercalações delgadas de arenitos conglomeráticos, nas quais se destacam grânulos e seixos de K-feldspatos esbranquiçados. Ponto CA-11

Figura 4.7.8 - Extremo noroeste da bacia, na região do Rio dos Motas com vista panoramica de escarpamento formado pelos arenitos e conglomerados da Formação Furnas que repousam, erosivamente, sobre os depósitos da Bacia de Camarinha 


\section{ÍNDICE DAS TABELAS}

Tabela 4.4.1 -. Relação das amostras analisadas neste projeto, com a sua localização e classificação petrográfica.

Tabela 4.4.2 - Resultados analíticos de isótopos estáveis de C e O para as amostras analisadas da Bacia de Cajamar e do Subgrupo Lageado, região do PETAR ........ 91

\section{ANEXO 1}

Tabela 1 - Resultados analíticos de elementos maiores das amostras de seixos de riólitos, de metalaminitos com cinzas vulcânicas e de metassiltitos e metarenitos.

Tabela 2 - Resultados analíticos para elementos traços, de amostras de seixos de riólitos, de metalaminitos com cinzas vulcânicas e de metassiltitos e metarenitos. 


\section{INTRODUÇÃO}

O tema proposto para estudos, "bacias da transição", vem instigando vários autores, entre eles Almeida (1967 e 1969), Ebert (1968 e 1971), Wernick \& Penalva (1974), Hasui et al. (1982) e Cordani et al. (1984), preocupados em identificar os processos que teriam ocorrido no intervalo entre a última orogenia brasiliana e a instalação da sinéclise do Paraná no interior da Plataforma Sul-Americana. Quase sempre, a abordagem ocorreu dentro de uma perspectiva da teoria geossinclinal, onde tais depósitos seriam representativos de "molassas" ou "molassóides". Com o advento da teoria das placas tectônicas, que no Brasil viria tornar-se mais difundido apenas na década de 80 , e com o interesse crescente dos pesquisadores em todo o mundo em definir melhor a passagem Proterozóico-Fanerozóico, seja quanto aos processos biológicos e tectônicos envolvidos como quanto à melhor precisão de tal limite, até então tido como ocorrido aos 575 $\mathrm{Ma}$, é que tais bacias das regiões sul e sudeste, principalmente, começaram a ganhar um novo aporte de investigações.

E como seria de se esperar, não faltaram ensaios de modelagens que implicaram, de acordo com o modelo tectônico proposto, em classificá-las em várias categorias, tais como bacias de foreland, piggy-back, pull-apart, aulacógenos tardios, rifts continentais, intermontanas, etc. Acreditamos, portanto, que só a partir da década de 90 é que, verdadeiramente, foram dados os principais passos para a sua caracterização, à medida em que o conteúdo sedimentar, paleontológico e das feições estruturais e tectônicas das bacias da transição começaram a ser melhor investigados, utilizando-se de estudos específicos.

O que hoje pode ser vislumbrado é uma íntima associação cronológica e, possivelmente, estratigráfica de tais depósitos com aqueles considerados como coberturas cratônicas plataformais, como o Grupo Corumbá e, talvez, Alto Paraguai, além de outros ainda pouco estudados no Brasil. Do mesmo modo, parecem existir similaridades maiores, estratigráficas e paleontológicas, com os depósitos do Grupo Arroyo del Soldado (Gaucher et al. 1996), situado no Uruguai, cujas descrições estão sintetizadas em Gaucher et al. (1998) e Gaucher (2000).

Desse modo, em que pese a forte tendência atual de se classificar tais bacias como sendo de afastamento (pull-apart), num contexto de zonas de cisalhamentos com movimentações laterais (strike-slip) ocorridas durante os processos finais de amalgamação do Gondwana Ocidental, as características dos depósitos, à luz dos novos dados obtidos, parecem contradizê-la, pelo menos em parte. 
No presente trabalho, estão descritas as atividades desenvolvidas durante o projeto de pesquisa "Análise das bacias da transição Proterozóico-Fanerozóico do Estado de São Paulo e adjacências" e analisados os resultados obtidos. As atividades desenvolvidas no decorrer da pesquisa compreenderam levantamentos bibliográficos, cartográficos e de campo, análises laboratoriais e atividades de escritório, envolvendo a interpretação e integração dos dados obtidos.

Manteve-se aqui a denominação de "bacias da transição Proterozóico-Fanerozóico", em decorrência da precariedade, ainda, de dados geocronológicos e/ou paleontológicos que pudessem melhor situá-las cronoestratigraficamente. Como será visto adiante, os dados obtidos apontam sedimentação extensiva até o final do Neoproterozóico (Neoproterozóico III), não se descartando, desse modo, a possibilidade de ter atingido o início do Cambriano, o que poderá ser testado em trabalhos futuros, quando os estudos paleontológicos forem melhor aprofundados.

\section{1. Área dos Estudos}

A área dos estudos se estende desde o sul de Minas Gerais até o nordeste do Estado do Paraná, percorrendo o Estado de São Paulo, segundo direção NE-SW, que grosso modo acompanha a Faixa de Dobramentos Ribeira (Hasui et al. 1975). Entretanto, as exposições rochosas não são contínuas, restringindo-se a corpos isolados preservados da erosão e embutidos entre falhas que constituem ramificações de importantes zonas de cisalhamentos, que modelam o arcabouço estrutural da região sudeste.

Desse modo, como pode ser visto na Figura 1.1.1, ocorrem nos limites dos estados de São Paulo e Minas Gerais as bacias de Eleutério, do Pico de Itapeva e a de Pouso Alegre, esta última totalmente no Estado de Minas Gerais. Nas proximidades da Grande São Paulo ocorreriam os corpos das bacias de Salto de Pirapora, de Pirapora do Bom Jesus e, em subsuperficie, a Bacia de Cajamar. Na região sul do Estado de São Paulo estão localizadas as bacias do Samambaia e do Quatis e, finalmente, a Bacia de Camarinha, situada na região da Grande Curitiba. 


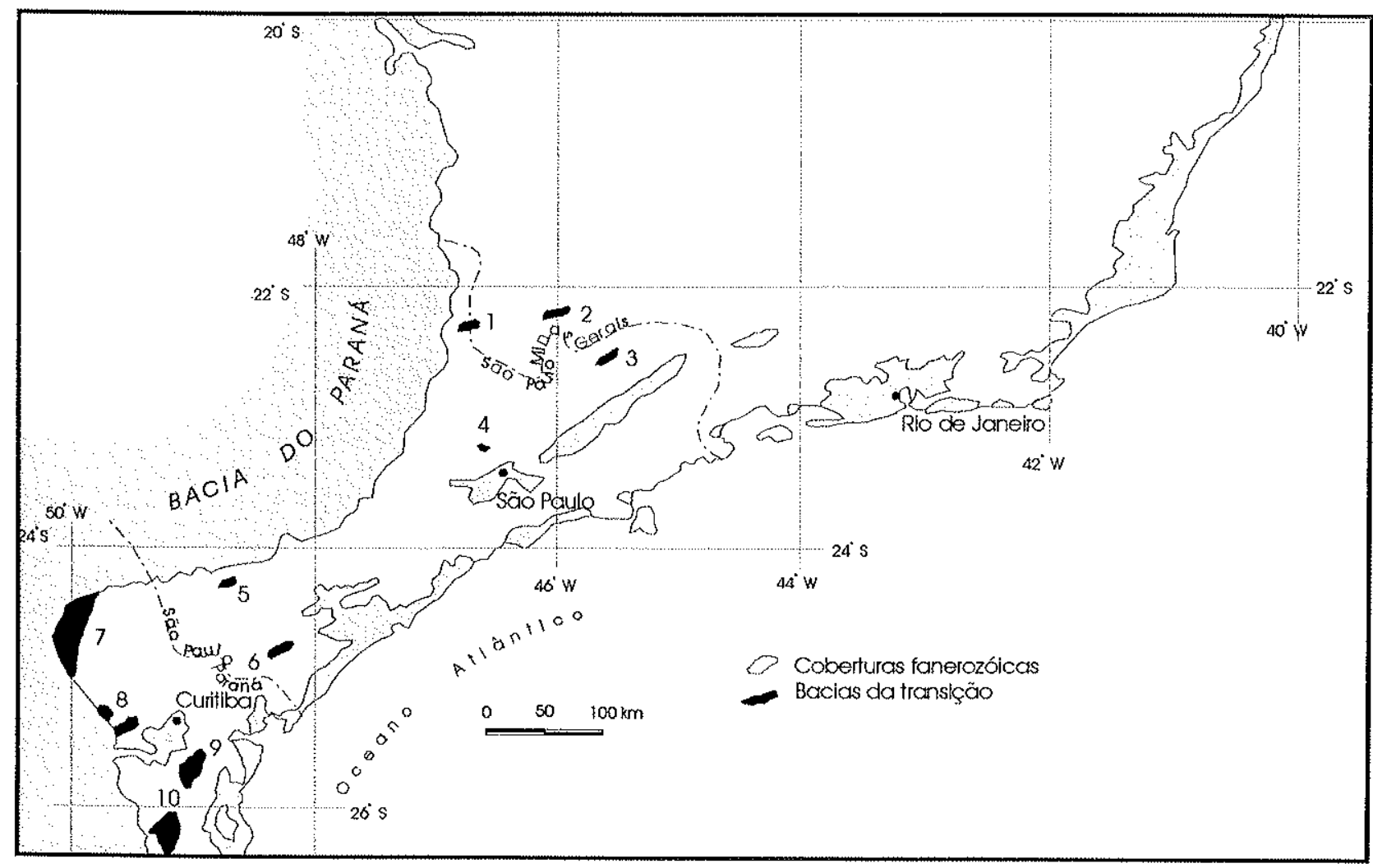

Figura 1.1.1 - Localização das bacias da transição Proterozóico-Fanerozóico do Estado de São Paulo e adjacências: 1. Eleutério, 2. Pouso Alegre, 3. Pico de Itapeva, 4. Cajamar, 5. Samambaia, 6. Quatis, 7. Castro, 8. Camarinha, 9. Guaratubinha, e 10. Campo Alegre.

As rochas da Bacia de Eleutério expõem-se desde WSW da localidade de Eleutério (Município de Itapira, SP), encosta norte do Morro de Picura, até o norte de Jacutinga (MG), onde atinge o Rio Mogi-Guaçu, descrevendo estreita faixa alongada com direção ENE-WSW, com cerca de $16 \mathrm{~km}$ de comprimento e largura variável de 0,3 a 1,3 km. Está compreendida entre os paralelos $22^{\circ} 15^{\prime}$ e $22^{\circ} 20^{\prime}$ de latitude sul e meridianos $46^{\circ} 38^{\prime}$ e $46^{\circ} 46^{\prime}$ de longitude oeste. Alguns restos destas rochas, isolados do corpo principal, ocorrem até cerca de $5 \mathrm{~km}$ a oeste de Mogi-Guaçu e a $2,5 \mathrm{~km}$ a norte de Jacutinga. $\mathrm{O}$ acesso até à área se faz através de Itapira (SP), que dista $180 \mathrm{~km}$ da capital, e daí dirigindo-se até Eleutério distante $16 \mathrm{~km}$, daquela comarca, de onde, em direção noroeste, percorrendo-se 1,5 km em direção à Fazenda Salto, intercepta-se a unidade. De Itapira (SP) passando-se por Eleutério, através da SP-352/MG-162 até atingir Jacutinga (MG), após $36 \mathrm{~km}$, atinge-se o extremo NE da área, no Bairro de São Luís, a 3,5 km deste último município.

Os depósitos do Pico de Itapeva, por sua vez, ocorrem a cerca de $10 \mathrm{~km}$ a sudeste da cidade de Campos do Jordão, situada a cerca de $180 \mathrm{~km}$ da capital do Estado, aproximadamente entre os paralelos $22^{\circ} 43^{\prime}$ e $22^{\circ} 47^{\prime}$ de latitude sul e meridianos $45^{\circ} 25^{\prime}$ e $45^{\circ} 35^{\prime}$ de longitude oeste. $\mathrm{O}$ acesso até Campos do Jordão é feito através da Rodovia SP-123, que se conecta ao sistema Rodovia Presidente Dutra na altura de Taubaté. Em Campos do Jordão, toma-se estrada vicinal 
pavimentada no Bairro do Capivari, que se dirige até a borda do planalto com mesmo nome da cidade, onde se expõem os metassedimentos da bacia que sustentam o principal mirante turístico da região do Pico de Itapeva.

A Bacia de Pouso Alegre dista cerca de $210 \mathrm{~km}$ de São Paulo, capital, e localiza-se entre os paralelos $22^{\circ} 11^{\prime}$ e $22^{\circ} 14^{\prime}$ de latitude sul e meridianos $45^{\circ} 57^{\prime}$ e $46^{\circ} 00^{\prime}$ de longitude oeste. $\mathrm{O}$ acesso é feito pela Rodovia Fernão Dias (BR-381), que liga essa capital a Belo Horizonte e que passa pelo município de Pouso Alegre. Desta cidade, tomando-se o destino para Poços de Caldas (MG-65), após cerca de $5 \mathrm{~km}$ os primeiros depósitos estarão expostos em corte da rodovia, quando esta atravessa a Serra de Santo Antônio.

As ocorrências relacionadas com as bacias de Salto de Pirapora e de Pirapora do Bom Jesus estariam, respectivamente, nos municípios homônimos. Entretanto, os mapas de localizações e as descrições sobre as ocorrências disponíveis na literatura mostraram-se insuficientes para certificar as suas existências. No caso específico da Bacia de Salto de Pirapora, cujos depósitos estariam expostos quase dentro da área urbana, o que se verificou foi a presença de depósitos conglomeráticos (polimíticos arenosos) atribuíveis ao Subgrupo Itararé, sobrepostos por pelitos da mesma unidade e, estratigraficamente, sobre calcários do Grupo São Roque, nas proximidades da mineração MINERCAL.

Os depósitos da Bacia de Cajamar localizam-se na cidade homônima, na Região Metropolitana de São Paulo, a cerca de $20 \mathrm{~km}$ da capital, aproximadamente onde cruzam o paralelo $23^{\circ} 21^{\prime} 30^{\prime \prime} \mathrm{S}$ e o meridiano $46^{\circ} 52^{\prime} 30^{\prime \prime} \mathrm{W}$.

Os depósitos da Bacia do Samambaia situam-se na região sudeste do Estado de São Paulo, entre as cidades de Guapiara e Ribeirão Branco, às margens do Ribeirão de mesmo nome, e entre os paralelos $24^{\circ} 15^{\prime}$ e $24^{\circ} 19^{\prime}$ de latitude sul e meridianos $48^{\circ} 39^{\prime}$ e $48^{\circ} 44^{\prime}$ de longitude oeste. Distam cerca de $300 \mathrm{~km}$ da capital do Estado, fazendo-se o acesso pela Rodovia Castelo Branco até a altura de Tatuí, quando se toma a rodovia SP-127 até Capão Bonito e daí até Guapiara, rodovia SP-250. De Guapiara o acesso se faz a partir de estrada municipal secundária até às margens do Ribeirão Samambaia, que distam cerca de $5 \mathrm{~km}$ desta cidade.

A Bacia do Quatis ocorre nas cimeiras da Serra da Boa Vista, remanescentes do Planalto Guapiara, que avançam até oeste de Cajati, no sul do Estado, entre os paralelos $24^{\circ} 42^{\prime}$ e $24^{\circ} 44^{\prime}$ de latitude sul e meridianos $48^{\circ} 14^{\prime} \mathrm{e} 48^{\circ} 18^{\prime}$ de longitude oeste. Distam cerca de $240 \mathrm{~km}$ da capital do Estado, fazendo-se o acesso pela BR-116, Rodovia Régis Bittencourt, até a altura de Jacupiranga, quando se toma a direção de Iporanga. Na altura da localidade de Barra do Batatal, toma-se a estrada secundária em direção ao Bairro dos Porcos, de onde, ainda com veículo, 
pode-se atingir o sopé da Serra da Boa Vista. O trajeto seguinte é feito a pé, em região de mata primária e secundária, com desnível total superior aos $500 \mathrm{~m}$, quando nas cabeceiras do Ribeirão dos Porcos poderão ser encontradas as primeiras ocorrências dos depósitos. As condições ínvias impediram a realização de qualquer campanha de campo nesta unidade, ficando as descrições neste relatório subordinadas àquelas da literatura.

E, finalmente, os depósitos da Bacia de Camarinha situam-se a cerca de $35 \mathrm{~km}$ de Curitiba, no município de Campo Largo, Grande Curitiba, entre os paralelos $25^{\circ} 18^{\prime}$ e $25^{\circ} 28^{\prime}$ de latitude sul e meridianos $49^{\circ} 30^{\prime}$ e $49^{\circ} 50^{\prime}$ de longitude oeste. O acesso de São Paulo é feito pela BR-116, Rodovia Régis Bittencourt, até Curitiba e, desta capital, pela BR-277 (Curitiba-Ponta Grossa), quando entre Campo Largo e a localidade de São Luís do Purunã estão expostos, em vários cortes da rodovia, as rochas da Bacia de Camarinha.

\subsection{Objetivos e Métodos}

O objetivo da pesquisa foi o reconhecimento e análise das feições sedimentares e tectônicas presentes nas bacias em questão, buscando-se estabelecer correlações entre elas que permitissem, ou não, traçar um quadro evolutivo comum para as mesmas, no contexto da evolução Proterozóico-Fanerozóico do Gondwana Ocidental e, em particular, ao longo da Faixa de Dobramentos Ribeira, entre os estados de Minas Gerais e Paraná.

De acordo com o proposto, os métodos utilizados compreenderam:

a) compilação e análise do acervo bibliográfico e cartográfico disponível sobre cada uma das bacias envolvidas;

b) análise de produtos de sensores remotos, principalmente fotografias aéreas na escala 1:25.000, como suporte para reinterpretações geológicas;

c) levantamentos de campo, acompanhados da descrição de afloramentos de rocha e suas estruturas, coleta de amostras, documentação fotográfica e confecção de perfis geológicos;

d) análises laboratoriais de amostras selecionadas, previamente coletadas no campo, e integração dos dados obtidos; e

e) redação da Qualificação e Tese.

As atividades desenvolvidas, para se alcançar os objetivos propostos, consistiram em: 


\subsubsection{Fotointerpretação Geológica}

As atividades de fotointerpretação geológica, além da fotointerpretação preliminar, destinada principalmente ao planejamento dos trabalhos de campo, foram constantemente requeridas, à medida que se avançavam nos levantamentos de campo, quando novos dados de superfície eram agregados à cartografia.

\subsubsection{Levantamentos de Campo}

Os levantamentos de campo foram sempre precedidos da compilação bibliográfica e cartográfica e da fotointerpretação preliminar, que subsidiaram as campanhas de campo propriamente ditas. Inicialmente, e quase sempre, procedia-se a um reconhecimento geral de cada unidade, acompanhado da descrição de afloramentos ou de perfis destes e da coleta de amostras e da documentação fotográfica. Num segundo momento, procedeu-se ao levantamento mais sistemático dos pontos de afloramento, buscando-se, assim, adensar as informações geológicas e cartográficas. Entre as campanhas de campo, as análises laboratoriais foram executadas de acordo com o problema a ser resolvido e com os métodos propostos.

\subsubsection{Análises Laboratoriais}

As análises laboratoriais foram as seguintes:

a) Análise de dados de paleocorrentes - A análise das estruturas direcionais planares e lineares obtidas em estratificações e laminações cruzadas nortearam-se pelos conceitos expressos em Ramsay (1961), Graham (1988) e Collinson \& Thompson (1989), entre outros, adaptados em Teixeira (1996). A análise estatística dos dados recebeu tratamento computacional complementar, utilizando-se dos softwares Rockware Utilities, versão 2.0, da RockWare, Inc. (EUA) e Stereo Nett, versão 2.40, criado por Johannes P. Duyster, do Institut für Geologie, da Ruhr-Universitärt-Bochum, Alemanha, com os quais, também, se obteve a representação gráfica dos resultados.

b) Análises petrográficas - em todas as amostras de rochas procedeu-se a descrição petrográfica, buscando identificar os minerais constituintes, a classificação dos metassedimentos, os processos de recristalização e neoformação de minerais e os aspectos microtectônicos envolvidos. Além disso, auxiliou no direcionamento da seleção de amostras para os diferentes tipos de análises químicas, geocronológicas e de isótopos estáveis. 
c) Análises litogeoquímicas - Inicialmente foram realizadas análises litogeoquímicas em 9 seixos de riólitos de metaconglomerados polimíticos do ponto ET-54 (Ocorrência isolada $\mathrm{I}_{4}$, na Bacia de Eleutério) e em uma única amostra de possível dique riolítico obtido no Poço 2-PN-1-SP (Paranapanema), realizado pelo Consórcio PAULIPETRO, à profundidade de $1,68 \mathrm{~km}$ aproximadamente. Essas análises foram realizadas no Laboratório do Departamento de Mineralogia e Geotectônica do IG-USP, compreendendo elementos maiores e traços, através da Fluorescência de Raios-X e ICP (Inductively Coupled Plasma Emission Spectometry).

Posteriormente, foi selecionado um total de 30 amostras de rocha das bacias Eleutério, principalmente, Cajamar, Camarinha e Pouso Alegre, que foram encaminhadas para análises litogeoquímicas (elementos maiores, traços e terras raras) no Activation Laboratories (ACTLABS), do Canadá, e realizadas de acordo com o código 4LITHO, pelos métodos de ICP-MS, para elementos traços, e ICP com fusão de metaborato/tetraborato de lítio, para elementos maiores.

d) Análises geocronológicas - nas mesmas amostras de riólitos acima relacionadas foram concentrados minerais pesados para a separação de cristais de zircão, para datações radiométricas, pelo método $\mathrm{U} / \mathrm{Pb}$ monocristal, no laboratório da Australian National University, situada em Canberra, Austrália, com a utilização do SHRIMP (Sensitive High Resolution Micro-Probe). Em função de sua representatividade e melhor cristalinidade e pureza dos grãos, uma destas amostras (ET-54-11) teve 4 cristais de zircão analisados.

Foram, também, selecionadas amostras de seixos de riólitos, de metalaminitos com cinzas vulcânicas intercaladas e de metassiltitos das bacias Eleutério, para datações $\mathrm{Sm}-\mathrm{Nd}$ e Rb-Sr, encaminhadas para o Centro de Pesquisas Geocronológicas do Instituto de Geociências da USP - CEPEGEO, objetivando obter idades modelos das rochas, trajetórias evolutivas das fontes e subsidiar interpretações paleotectônicas.

Os resultados parciais obtidos até o momento não oferecem, em seu conjunto, subsídios para análises mais apuradas. Considerando-se, ainda, que esses resultados ficaram disponíveis apenas quando se fechava este texto final, deverão ser contemplados em trabalhos futuros. 
e) Análises de microscopia eletrônica de varredura (MEV) - foram dirigidas especificamente para os metalaminitos do ponto ET-50 (Bacia de Eleutério), onde se buscou caracterizar a composição e cristalinidade dos grãos de quartzo (bipiramidados, glass shard etc.), além de outros minerais indicativos das condições genéticas da intercalação, como o zircão.

f) Catodoluminescência em rochas carbonáticas - foram realizadas análises em 6 seções delgadas de carbonatos da Bacia de Cajamar, onde se buscou localizar "pontos/regiões" não luminescentes que pudessem fornecer material isento de contaminações de $\mathrm{Mn}$ e Fe, para a análise de isótopos estáveis de C e O.

g) Difração de raios-X - foram realizadas em metalaminitos do ponto ET-50, da Bacia de Eleutério, e em rochas carbonáticas da Bacia de Cajamar. No primeiro caso, objetivaram subsidiar análises composicionais e petrográficas para o exame de potenciais cinzas vulcânicas intercaladas em metassiltitos argilosos. No segundo caso, subsidiar procedimentos laboratoriais para análises de isótopos estáveis de $\mathrm{C}$ e $\mathrm{O}$.

h) Análise de isótopos estáveis de $\mathrm{C}$ e $\mathrm{O}$ - foram realizadas em 5 amostras da Bacia de Cajamar e em 2 amostras de mármores calcíticos do Grupo Açungui, utilizadas como parâmetro para comparações. Foram executadas pelo Laboratório de Isótopos Estáveis - LABISE da Universidade Federal de Pernambuco.

\section{SÍNTESE DOS CONHECIMENTOS ANTERIORES}

As primeiras referências aos depósitos da transição Proterozóico-Fanerozóico do Estado de São Paulo devem-se a Almeida (1964), que identificou "nos quartzitos que sustentam a borda sudeste do planalto (de Campos do Jordão), onde se ergue o pico de Itapeva, (...) intercalações de metaconglomerados com seixos muito deformados de granito, gnaisse e quartzo, não sendo improvável que representem seqüência basal de um grupo de sedimentos". Mais tarde, (e.g., Cavalcante et al. 1979 e Juliani et al. 1990) estes depósitos foram correlacionados aos eventos da transição.

Ao discorrer sobre a Origem e Evolução da Plataforma Brasileira, Almeida (1967) considerou que "(...) os grandes ciclos tecto-orogênicos são seguidos de períodos geocráticos em que generalizado recuo dos mares expõe vastas extensões continentais aos processos gliptogênicos". Na América do Sul, segundo o autor, o Ciclo Baicaliano deve ter conduzido às 
mesmas conseqüências, situando no Cambro-Ordoviciano o período com caráter geocrático, em uma fase paraplataformal. Associados a esta fase Almeida (1967) identificou, espalhados pela imensa área paraplataformal, “(...) numerosas formações e grupos que manifestam certas características em comum, que os distingui (sic.) dos sedimentos paleozóicos mais novos". Chamou a atenção do autor o fato de estes depósitos ocuparem, “(...) freqüentemente áreas restritas, no que muito contrastam com a vastidão, pôsto ( $\mathrm{sic}$ ) que de espessura geralmente modesta, das formações eopaleozóicas mais novas"; as “(...) condições de fixação relacionadas com tectonismo epeirogênico local"; suas relações com as grandes falhas; a ausência de metamorfismo ou de grau muito fraco; a sedimentação predominantemente continental, cujo caráter imaturo reflete-se na abundância de arcóseos, grauvacas e conglomerados; e, ainda, o fato de "(...) diversas dessas formações apresentarem intercalações de produtos de vulcanismo ácido a intermediário, menos freqüentemente básico".

Almeida (1967) ressaltou as dificuldades em se analisar a história tectônica da paraplataforma brasileira, tendo em vista a esterilidade em fósseis de seus depósitos correlatos e a conseqüente impossibilidade para se estabelecer uma bioestratigrafia, o que poderia ser compensado, no futuro, com o avanço da geotectônica e da geocronologia. Ressaltou, também, a existência de outras formações com as mesmas características descritas acima, mas de idades duvidosas, que por se situarem fora das áreas dobradas baicalianas (brasilianas), poderiam remontar até ao Arqueano.

Os depósitos da Bacia de Camarinha (PR) foram referenciados, primeiramente, em trabalhos de levantamentos sistemáticos por Fuck (1966) e Muratori (1966) e Muratori et al. (1967), que os situaram sobrepostos às rochas metamórficas do Grupo Açungui e sotopostos aos sedimentos devonianos da Formação Furnas, a oeste de Curitiba. Muratori et al. (1967) identificaram siltitos e conglomerados intercalados, deformados e dobrados por falhamentos póssedimentação. Associaram esses depósitos com aqueles da Formação Maricá do Rio Grande do Sul, em função das similaridades litológicas e estruturais e, com menor ênfase, com aqueles das bacias vulcano-sedimentares de Castro e Guaratubinha, no Paraná. É constituída de conglomerados polimíticos e siltitos argilosos a conglomeráticos que se intercalam de noroeste para sudeste, verificando-se maior predomínio de pelitos neste último sentido. Muratori et al. (1967) verificaram que as camadas dispõem-se com mergulhos médios de $45^{\circ}$ para noroeste encontrando-se dobradas com ápices voltados para nordeste, entretanto os autores não concluíram sobre as características da grande estruturação e suas relações com a fase de inversão e com os falhamentos presentes. Quanto aos aspectos sedimentológicos concluíram pela 
imaturidade mineralógica e textural dos depósitos, caracterizando intemperismo físico predominante na fonte e transporte rápido de detritos de áreas próximas. Os autores destacaram a presença constante de estruturas gradacionais nos termos pelíticos e psefíticos e a presença de intraclastos pelíticos nos termos psamíticos a psefíticos. Associaram as estruturas gradacionais a uma deposição de fluxos densos originados por correntes de turbidez, "originadas por corridas de lama, adentrando um ambiente marinho tectônicamente instável". Por outro lado, atribuíram uma idade para a bacia com intervalo inferior situado em $600 \mathrm{Ma}$ (último metamorfismo no Grupo Açungui) e superior entre 450-500 Ma (idade das efusivas ácidas do Brasil Meridional).

Ebert (1968) reconheceu na Zona de Falha Itapira-Jacutinga-Ipuiúna, especificamente no seu trecho entre Itapira (SP) e Jacutinga (MG) que inflete a direção de NNE-SSW para ENEWSW, o embutimento de sedimentos muito pouco metamórficos e aparentemente mais jovens que os paragnaisses e granitos milonitizados encaixantes. Considerou que tal embutimento de sedimentos mais jovens teria sido possível a partir de um rejuvenescimento da falha em época posterior à tectônica do geossinclíneo "Paraíba", ou pós-assíntica.

Novamente, Almeida (1969) em seu outro célebre trabalho "Diferenciação Tectônica da Plataforma Brasileira", estabeleceu os pilares fundamentais para o estudo e compreensão das bacias brasileiras da transição, inabaláveis até hoje, mesmo com o advento da teoria da tectônica de placas, que gradualmente reformulou os conceitos e interpretações acerca da evolução plataformal. Como expoente máximo da teoria geossinclinal no país, o autor enfeixou as referidas bacias dentro do "estádio de transição" da plataforma, situado entre a etapa geossinclinal e a ortoplataformal (de estabilização). Estas bacias seriam reflexos diretos deste estádio de transição, iniciado com a inversão geossinclinal, geradas sobre as faixas dobradas e nas imediações das bordas cratônicas, em condições tipicamente paraplataformais. Baseando-se no conceito de seqüências estratigráficas de Sloss (1963), o autor distinguiu seis seqüências cronoestratigráficas relacionadas aos eventos da diferenciação plataformal, denominadas de I a VI. A seqüência I (Cambro-Ordoviciano) correspondente ao estádio de transição, foi por ele definida e as demais modificadas (de Mesner \& Wooldridge 1964 e Gomes 1968, apud Almeida 1969), correspondendo as seqüências II e III (Siluriano Inferior ao Triássico) ao estádio de estabilização e as seqüências IV, V e VI (Jurássico Superior ao Pós-Eoceno) ao estádio de reativação. Na seqüência Cambro-Ordoviciana (I) estariam os depósitos continentais molássicos ou molassóides imaturos, de coloração avermelhada, afossilíferos e condicionados em bacias intermontanas e de antefossas, posteriormente deformadas. 
Referenciando-se principalmente nas bacias da região central do Rio Grande do Sul, Almeida (1969) definiu três fases sucessivas, correspondentes a uma evolução estrutural, para as referidas bacias: 1) sedimentação não molássica, anterior ao vulcanismo subseqüente, quando a mobilidade da faixa era suficientemente grande para gerar dobramentos por compressão (Formação Maricá, inferior); 2) fase molássica, com predomínio de falhamentos ativos sobre dobramentos em área relativamente consolidada e com vulcanismo associado (Grupo Bom Jardim e Formação Santa Bárbara) e; 3) fase superior, que reflete o final do vulcanismo e a calmaria tectônica (formações Guaritas e Coxilha). A partir destas considerações, Almeida (1969), correlacionou as bacias semelhantes de Santa Catarina, Paraná, Mato Grosso, Sergipe, Bahia, Ceará, além daquelas situadas no Uruguai e Paraguai.

Como se pode depreender do exposto, Almeida (1969) não mencionou a ocorrência de qualquer bacia da transição no Estado de São Paulo que pudesse ser correlacionada com as demais.

Petri \& Suguio (1969), ao analisarem os metassedimentos do Grupo Açungui (Marini et al. 1967) no extremo sul do Estado, identificaram às margens do Ribeirão Samambaia, a cerca de $8 \mathrm{~km}$ a sudoeste de Guapiara, uma sucessão de sedimentos imaturos textural e mineralogicamente, constituída de metaconglomerados, metarenitos conglomeráticos e metarenitos intercalados. Atribuíram uma deposição rápida para os depósitos a partir de áreasfonte próximas, onde predominavam rochas graníticas sujeitas à erosão intensa, o que não permitiu o desenvolvimento de manto de intemperismo, a julgar pela abundância de grãos de feldspatos angulosos, matriz arcosiana e cimentação pouco desenvolvida. Verificaram que estes depósitos apresentavam características bem distintas dos metassedimentos do Grupo Açungui, mas semelhanças com as "molassas" pós-orogênicas, o que levou os autores a atribuir-lhes uma idade pós- Açungui e pós-intrusão granítica.

Ebert (1971) retomou sucinta descrição dos depósitos situados próximos à localidade de Eleutério, município de Itapira, associados à Zona de Falha Itapira-Jacutinga-Ipuiúna, propondoIhes a denominação informal de Grupo Eleutério, constituído de folhelhos, siltitos e arcóseos (às vezes conglomeráticos) e "isentos de metamorfismo" (sic.). Supôs que esta seqüência deveria ser mais jovem que os metassedimentos do Grupo Itapira (Ebert 1971), porém mais antiga "do que os últimos fortes movimentos ao longo da falha Itapira-Ipuiúna-Dourado do Espírito Santo" e da mesma idade das rochas do Grupo Itajaí, em Santa Catarina. Considerou, ainda, que a seqüência talvez representasse restos de uma ligação pretérita entre as rochas do referido grupo e aquelas das porções inferiores do Grupo Bambuí (Braun 1968), ao norte. 
Ebert (1984, in memoriam) descreveu os depósitos da Bacia de Eleutério como "quase não metamórficos", dispostos em concordância (estrutural) com os micaxistos do Grupo Itapira e com as falhas principais. Reconheceu nos limites ocidentais do corpo lentiforme: folhelhos, siltitos arcoseanos e arcóseos (fração areia) portadores dos feldspatos típicos (oligoclásio, microclina e mirmequita) dos granitos Pinhal, situados a noroeste. Uma vez que não verificara a presença de fragmentos de rochas milonitizadas nas litologias descritas, Ebert (1984, op.cit.) interpretou que os depósitos da Bacia de Eleutério não poderiam ser mais jovens que os falhamentos regionais e a milonitização acompanhante. Tentou elucidar tal "contradição" (sic.) com a hipótese de que esses depósitos pertenceriam a um horizonte estratigráfico e tectônico situado acima do Pré-Cambriano Superior e que a sua posição primária na superfície permitiralhes escapar dos processos de milonitização ocorridos em profundidade. A reativação dessas falhas antigas teria permitido, nesse lugar, o embutimento parcial daquele horizonte entre duas falhas e a sua conseqüente preservação dos processos erosivos que afetaram toda a região.

À mesma época, Leonardos Júnior et al. (1971) descreveram, a cerca de $10 \mathrm{~km}$ a noroeste de Pouso Alegre (MG), sedimentos pouco metamorfizados englobando metaconglomerados polimíticos, metarenitos feldspáticos, metarcóseos, metassiltitos e metamargas, os quais denominaram de Formação Pouso Alegre, destacando-os das rochas do embasamento constituído de micaxistos e gnaisses de grau metamórfico mais alto. A exemplo das demais bacias da transição, o condicionamento desta por falhamentos é nítido, assim como as características dos depósitos que evidenciam condições enérgicas para a deposição, com provável tectônica sinsedimentar. Essas características e o fato de estar situada dentro do Cinturão de Cisalhamento Ouro Fino (Cavalcante et al. 1979), juntamente com a Bacia de Eleutério, faz supor que estiveram ligadas preteritamente, constituindo uma mesma bacia. Reforça esta hipótese o registro de uma série de pequenas ocorrências isoladas existentes entre ambas, descritas e a elas correlacionadas por Soares (1976) e Vasconcellos (1988).

Wernick \& Penalva (1974) descreveram os limites tectônicos da Bacia de Eleutério, em sua porção ocidental, com os granitos Pinhal, através da Falha de Jacutinga e, ao sul, com o Grupo Itapira, através da "Brecha (tectônica) dos Machados". Distinguiram na bacia: a) arenitos arcoseanos e arcóseos mal selecionados e freqüentemente maciços, ora com estratificações cruzadas, estruturas gradacionais e de corte e preenchimento e com clay ball, intercalados por siltitos e conglomerados; b) siltitos compactos com fratura conchoidal na forma de seixos intraclásticos, como intercalações ou alternados aos arcóseos e com camadas espessas e maciças; e c) brechas conglomeráticas. Os autores invocaram para os depósitos uma sedimentação em 
regime torrencial evoluindo para depósitos de águas mais calmas, situando-os como representativos de fase molássica do Grupo Itapira, equivalentes aos depósitos cambroordovicianos associados ao Ciclo Brasiliano (Almeida 1969).

Ebert (1974) apontou três diferenças básicas entre as rochas do que denominou novamente de Grupo Eleutério e os metassedimentos adjacentes (do Grupo Itapira): a) quanto ao ambiente de sedimentação; b) quanto ao grau metamórfico e diferentes profundidades do sítio de metamorfismo; e c) quanto às feições deformacionais, de vez que a milonitização não se manifesta nos anquimetamorfitos. Como propriedade comum, teriam a mesma disposição espacial, o que levou o autor a concluir que apenas os últimos processos tectônicos afetaram a ambos.

Os depósitos da Bacia de Eleutério foram referenciados por diversos autores em trabalhos de sínteses geológicas regionais ou temáticas, como Wernick et al.(1976), Rodrigues (1976), Soares (1976), Hama \& Cunha (1977), Fiori et al. (1978 e 1981), Artur (1980) e Wernick \& Penalva (1980).

Wernick et al. (1976) associaram os depósitos Eleutério aos metassedimentos do Grupo Itapira e correlacionaram ambos à Formação Pouso Alegre (Leonardos Júnior et al. 1971) e a outras formações molassóides cambro-ordovicianas associadas ao Ciclo Brasiliano.

Soares (1976) identificou na região de Santa Rita de Caldas e Ipuiúna (MG) pequena ocorrência de folhelhos sílticos vermelhos e arcoseanos, mal selecionados e, às vezes, conglomeráticos, associados à Falha do Cervo, a qual constitue extensão local da Falha de Jacutinga, com caráter transcorrente dextral. Correlacionou-os aos depósitos do Grupo Eleutério (Ebert 1971).

Rodrigues (1976) ao descrever o Falhamento Transcorrente de Jacutinga, identificou na "Brecha Tectônica dos Machados", que limita orientalmente esses depósitos com o embasamento, fragmentos angulosos de rochas gnaissicas, graníticas e básicas e considerou a sua origem associada com o falhamento em questão.

Hama \& Cunha (1977) correlacionaram os metassedimentos Eleutério com aqueles da Bacia de Pouso Alegre, para os quais obtiveram idade mínima de $524 \pm 20 \mathrm{Ma}$, pelo método $\mathrm{K} / \mathrm{Ar}$, em amostra de sericita-calco-xisto e de $485 \pm 15 \mathrm{Ma}$, pelo mesmo método, em biotita+sericita separadas da mesma amostra. Consideraram a biotita como produto neoformado durante o metamorfismo do pacote sedimentar, no que foram contestados por Choudhuri et al. 
(1978), que consideraram a biotita detrítica, provavelmente oriunda de áreas-fonte transamazônicas e rejuvenescida isotopicamente.

Fiori et al. (1978) situaram os depósitos Eleutério e Pouso Alegre como resultantes das manifestações finais do Ciclo Brasiliano, condicionados em bacias tectônicas e com sedimentação em ambientes com energia altamente variável, como planície de inundação, deltáico e fluvial.

Hasui et al. (1978) englobaram os metassedimentos da Bacia do Pico de Itapeva no Grupo Açungui (Marini et al. 1967), estendido até o leste paulista pelos autores. Descreveram ali conglomerados polimíticos, com seixos e calhaus bem arredondados de migmatitos, xistos e granitóides, imersos em matriz quartzosa recristalizada para quartzo-muscovita xisto e pouco migmatizada, que passam para quartzitos e filitos. Os clastos, achatados, estariam alinhados com a foliação da matriz e com as rochas adjacentes na direção N60 E. Reconheceram, porém, as dificuldades em se posicionar com segurança o seu significado estratigráfico.

Cavalcante et al. (1979) ao descreverem os metassedimentos do Pico de Itapeva, denominaram-nos informalmente de Formação Pico do Itapeva, por entenderem que seu caráter epimetamórfico se diferenciava das demais unidades circundantes. Descreveram passagens gradacionais dos metaconglomerados para metarenitos feldspáticos e, destes, para metassiltitos com estruturas sedimentares preservadas. Identificaram nos metaconglomerados seixos e blocos de leuco-granodioritos e, subordinadamente, quartzo, gnaisses e turmalina-quartzo xistos. Estando a base destes afetada por intensa cataclase, os autores reconheceram que poderiam ser confundidos com os migmatitos heterogêneos, também deformados, que apresentam estruturas pseudo-conglomeráticas. Além de descreverem e denominarem informalmente os depósitos da Bacia do Pico de Itapeva, Cavalcante et al. (1979) descreveram e cartografaram também os depósitos das bacias Eleutério e Pouso Alegre, com as quais a correlacionaram.

Entretanto, Almeida et al. (1981) e Bistrichi et al. (1981), considerando a definição de "Formação" atribuída por Cavalcante et al. (1979), preferiram manter os metassedimentos aflorantes no Pico de Itapeva dentro do Grupo Açungui. Ao mesmo tempo, os autores consideraram os depósitos da Bacia de Eleutério como os únicos representantes molassóides relacionados à fase de transição plataformal (Almeida 1969) no Estado de São Paulo e correlacionáveis com aqueles da Bacia de Pouso Alegre, em Minas Gerais. E, apesar de discriminarem cartograficamente os conglomerados descritos por Petri \& Suguio (1969) nas 
cabeceiras do Ribeirão Samambaia, no sul do Estado, optaram por inclú́-los no Grupo Açungui (Marini et al. 1967).

Hama et al. (1979) atribuíram um intervalo de $40 \mathrm{Ma}$ (entre 530-490 Ma) para o estágio de acomodação de tensões da crosta siálica brasiliana, quando então esta se estabilizou, baseando-se em datações $\mathrm{Rb} / \mathrm{Sr}$ em tectonitos e em remobilizados transamazônicos. Compararam esses valores com aqueles obtidos $(485 \pm 15 \mathrm{Ma}$ e $524 \pm 20 \mathrm{Ma})$ em datações $\mathrm{K}-\mathrm{Ar}$ nos metassedimentos Pouso Alegre (Hama \& Cunha 1977) e concluíram que existe uma coerência entre eles que, provavelmente, aponta para um significado real para os mesmos. A idade $485 \pm$ $15 \mathrm{Ma}$ (ordoviciana) para as biotitas e sericitas datadas, seria o registro do último deslocamento e aquecimento-resfriamento sofrido pela unidade, considerando-se a facilidade de liberação de argônio destes minerais.

Campanha et al. (1982) situaram os depósitos da Bacia de Eleutério no compartimento litoestrutural que denominaram Bloco Jacutinga, ao mapearem as áreas compreendidas no Estado de São Paulo da quadrícula Águas de Lindóia. Distinguiram três associações litológicas presentes: a) brechas e conglomerados polimíticos; b) siltitos, argilitos e folhelhos; e c) arenitos arcoseanos e arcóseos. Os autores afastaram a hipótese de um caráter molássico para os depósitos, em função da ausência de materiais vulcânicos associados. Atribuíram uma deposição rápida dos sedimentos, a partir de áreas-fonte muito próximas, em uma bacia tafrogênica associada ao Falhamento de Jacutinga. Observaram que as estruturas sedimentares, mesmo ao nível microscópico, encontram-se praticamente intactas e que tênue clivagem ardosiana, caracterizada pela orientação de cristais de sericita finamente cristalizados, intercepta obliquamente o acamamento. Esta, segundo os autores, poderia estar relacionada à deformação cisalhante que afetou inclusive o embasamento, ou então, a uma foliação plano-axial de dobramento aberto, não observado. Correlacionaram esses depósitos aos da Bacia de Pouso Alegre.

Hasui et al. (1982) identificaram na região de Pirapora do Bom Jesus uma pequena ocorrência de conglomerado polimítico, embutida por falhas, nos metassedimentos do Grupo São Roque e, a leste de Salto de Pirapora, também embutida por falhas no Grupo São Roque, identificaram uma outra ocorrência de conglomerados polimíticos, arenitos arcoseanos e arenitos finos. Associaram essas ocorrências aos depósitos da transição, como das bacias Eleutério e Pouso Alegre. 
Fúlfaro et al. (1982) consideraram que a implantação da Bacia do Paraná no Devoniano ocorreu sobre uma plataforma consolidada no Cambro-Ordoviciano, a partir de zonas de fraquezas com direção NW-SE, herdadas de aulacógenos tardios à cratonização. Os autores imputaram-lhes uma sedimentação de alta energia, compatível com a dos depósitos molássicos, e com caráter eminentemente continental. No entanto, prosseguem, esses sedimentos diferenciamse daqueles depositados em bacias intermontanas da fase final de consolidação plataformal, por serem estes levemente metamorfisados, dobrados e com vulcanismo de caráter ácido a intermediário associado.

Cordani et al. (1984) realizaram datações radiométricas em amostras de poços perfurados pela PETROBRÁS e PAULIPETRO na Bacia do Paraná. A partir destas e dos dados geofísicos e bioestratigráficos disponíveis, advogaram a existência de uma região estável, possivelmente um núcleo cratônico, sotoposta aos sedimentos da Bacia, em sua porção norte. Destacaram que os grandes traços estruturais e as faixas dobradas, teriam continuidade física sob os sedimentos da Bacia do Paraná, assim como os crátons Rio da Prata e Luiz Alves, os grupos Brusque e Porongos e um certo prolongamento da parte ocidental do Maciço de Guaxupé. Identificaram arenitos e siltitos com idades compatíveis com os depósitos de transição, ao redor de $500 \mathrm{Ma}$ Atribuíram para a instalação das sinéclises paleozóicas do Parnaíba e Paraná um condicionamento dado pela contração litosférica, que sucedeu a expansão térmica provocada pela orogênese brasiliana. Com uma grande probabilidade, segundo os autores, as sinéclises foram precedidas por grandes rifts e/ou aulacógenos preenchidos por seqüências sedimentares, como aqui enfocadas.

Hasui \& Oliveira (1984) propuseram unificar os anquimetamorfitos das bacias Eleutério e Pouso Alegre sob a denominação única de "Formação Pouso Alegre", em respeito ao princípio da prioridade. Tal proposição, ao que parece, não teve aceitação, uma vez que em trabalhos subseqüentes vários autores não a adotaram (e.g. Zanardo 1987, Artur 1988, Zanardo et al. 1988 e Zanardo \& Oliveira 1990).

Artur (1980 e 1988), ao analisar a possível proveniência dos detritos da Bacia de Eleutério, apontou diminuição geral da granulometria dos metassedimentos da porção oriental para a ocidental, sugerindo áreas-fonte situadas a leste. Descreveu nesses metassedimentos seixos e fragmentos de muscovita quartzitos e de gnaisses típicos do Bloco Jundiaí e constatou a ausência de seixos de migmatitos e granitóides do Grupo Pinhal, situado imediatamente a oeste. Atribuiu para a justaposição atual desses blocos com os metassedimentos Eleutério os efeitos de movimentações verticais ocorridas no Fanerozóico. Artur (1988) obteve idades em torno de 490 
Ma para a fase de cisalhamento rúptil da Zona Transcorrente Ouro Fino, o que, segundo o autor, coincide cronologicamente com a intrusão das fases pós-tectônicas equigranulares epizonais que cortam os batólitos calco-alcalinos porfiróides mesozonais e, ainda, coincide com a implantação das bacias pull-apart.

Schobbenhaus \& Campos (1984) e Hasui et al. (1984) incluíram entre os depósitos tardi a pós-tectônicos, relacionados ao final do Ciclo Brasiliano, no Estado de São Paulo, apenas aqueles da Bacia de Eleutério. Hasui et al. (1984) correlacionaram estes aos depósitos da Bacia de Pouso Alegre, situados a ENE, em Minas Gerais.

Campanha et al. (1985) e Campanha \& Teixeira (1986) descreveram uma nova ocorrência de sedimentos imaturos e pouco metamorfizados no sul do Estado, a qual denominaram informalmente de Formação Quatis. Situada a cerca de $15 \mathrm{~km}$ a oeste de Cajati, ocupa as porções cimeiras da Serra da Boa Vista, aflorando entre as cotas de 600 e $860 \mathrm{~m}$, a partir das cabeceiras do rio que the empresta o nome, em área de Mata Atlântica de acesso muito dificil. Descreveram, na unidade, metaconglomerados polimíticos, metarenitos arcoseanos ou não, metassiltitos e metargilitos, dispostos em intercalações centimétricas a métricas, com acamamento reliquiar bem definido e interceptado obliquamente por clivagem ardosiana incipiente, limitados tectonicamente, na porção meridional, pela Falha do Braço Grande, com direção NE, e, setentrionalmente, pelas bordas escarpadas da Serra da Boa Vista. Assentam-se em discordância erosiva sobre xistos da Seqüência Turvo-Areado e migmatitos do Complexo Pré-Setuva. Correlacionaram-na aos depósitos da transição Proterozóico-Fanerozóico do Estado do Paraná, como os das bacias Camarinha e Castro.

Soares (1987) atribuiu à sobrecarga litosférica, devido ao empilhamento tectônico de blocos crustais cavalgados, uma subsidência gerada em região de retro-arco, que propiciou o sítio deposicional das seqüências Camarinha-Antinha, com áreas-fonte no arco orogênico, que preencheram em ambientes continentais a marinhos a bacia de antepaís de retro-arco.

Soares (1988) correlacionou os depósitos da Bacia de Eleutério à associação litológica metamórfica 4 (tilitos-carbonatos-pelitos-arenitos vermelhos) que refletiu os eventos seqüenciados de sedimentação glacial, transgressão marinha e regressão com deposição continental, ocorridos numa fase colisional entre o bloco continental Paraná, submerso à bacia de mesmo nome (como proposto por Cordani et al. 1984), e os blocos microcontinentais (Luiz Alves, Pelotas e Espírito Santo) e continentais (Bolívia, Amazonas, Parnaíba, São Francisco, Kalahari, Nilo e Neokasai), entre 750 e 550 Ma aproximadamente. O autor denominou de 
"Seqüência Seara" várias ocorrências de sedimentos arcoseanos avermelhados, envolvendo conglomerados, arenitos e siltitos, identificadas em poços, desde o Rio Grande do Sul até São Paulo, que correlacionou com a associação litológica metamórfica 4. Segundo o autor, estes depósitos, com até $300 \mathrm{~m}$ de espessura, estariam condicionados à margem leste do Bloco Paraná, subductante aos microcontinentes Pelotas, Luiz Alves/Espírito Santo.

Campanha et al. (1988) retomaram as descrições sobre os metassedimentos "Samambaia", reconhecidos por Petri \& Suguio (1969) na porção sul do Estado. Além de situálos no contexto da Faixa de Dobramentos Apiaí, atribuíram-lhes uma deposição em bacia molássica, correlacionável com os depósitos da Formação Quatis (Campanha et al. 1985) situados próximos da cidade de Cajati.

Vasconcellos (1988) cartografou pequenas ocorrências correlacionáveis aos metassedimentos Eleutério/Pouso Alegre na região de Ouro Fino, compreendendo metarcóseos e metarenitos arcoseanos, magnetita-quartzo-sericita filitos, clorita-quartzo-sericita filitos e metarenitos conglomeráticos. Correlacionou a foliação metamórfica $\left(\mathrm{S}_{1}\right)$ desses metassedimentos, gerada na fase de dobramento D1, com a fase D3 regional do Grupo Andrelândia. Sugeriu que a sedimentação molassóide deve ter ocorrido durante os processos de cavalgamentos e falhamentos inversos tardios, relacionados a uma subducção do tipo A, que "jogou" sobre os terrenos proterozóicos médios da Faixa Alto Rio Grande (Hasui \& Oliveira, 1984) os alóctones brasilianos da Nappe de Empurrão Socorro-Guaxupé.

Zanardo (1987), Zanardo et al. (1988) e Zanardo \& Oliveira (1990) além de descreverem os aspectos texturais e petrográficos dos metarcóseos, metassiltitos, metargilitos siltosos e metaconglomerados e metabrechas da Bacia de Eleutério, realizaram minuciosa análise microestrutural destes metassedimentos. Concluíram pelo grau metamórfico baixo dessas rochas, atingindo temperaturas da ordem de $290^{\circ} \mathrm{C}$, com reações de transformação de argilominerais nos filossilicatos finos (illitas, sericita, hidromuscovita, clorita interestratificada com muscovita, etc) ao lado de processos de dissolução (pression solution); crescimento de quartzo em zonas de menor pressão, desenvolvimento de extinção ondulante e/ou lamelas de deformação nos pontos de maior pressão, rotação mecânica dos minerais, circulação de fluídos e transformação dos feldspatos em filossilicatos. A esses processos tectono-metamórficos atribuiram a geração de uma clivagem ardosiana nas rochas metapelíticas (mica beards), clivagem reticular nas metapsamíticas e clivagem de fratura nas metapsefíticas. Em certas regiões, processos de formação de biotita verde e/ou epídoto ocorreram, aparentemente mais intensos nos metapsefitos, onde as temperaturas, supostamente, atingiram valores mais elevados. A ausência 
de dobras e o relacionamento com a foliação milonítica da zona de falha, permitiram aos autores supor que o elemento motriz gerador da foliação metamórfica tenha sido o cisalhamento simples com possíveis componentes de cisalhamento puro, resultantes de movimentações ao longo da falha de Jacutinga. Os autores sugeriram que a sedimentação processou-se em ambiente continental de águas rasas, com rápidas variações de energia, possivelmente em leques aluviais, com áreas-fonte múltiplas localizadas predominantemente a sudeste, tendo em vista a presença de fragmentos líticos de granitos sub-vulcânicos, granófiros e milonitos de quartzitos. Corresponderia a uma bacia do tipo pull-apart gerada em locais de regimes transtensionais no contexto de uma movimentação transcorrente.

Juliani et al. (1990) reincorporaram para os depósitos do Pico de Itapeva, a sudeste de Campos de Jordão, a denominação de "Formação" atribuída por Cavalcante et al. (1979). Identificaram em uma estruturação sinclinal isoclinal, com superfície axial mergulhando para $\mathrm{SE}$, três unidades litológicas constituídas de metaconglomerados polimíticos na base, com mais de $700 \mathrm{~m}$ de espessura, metarcóseos com intercalações de metarenitos e metassiltitos arcoseanos na porção intermediária, com espessuras entre 200 a mais de $500 \mathrm{~m}$, com passagens gradacionais e interdigitadas com as unidades basal e do topo, constituída esta de cerca de $150 \mathrm{~m}$ de metarenitos finos arcoseanos e metassiltitos, com lentes de metapelitos, apresentando estruturas do tipo hummocky centimétricas a decimétricas. Os autores cartografaram esses depósitos em uma área alongada de $3 \mathrm{~km}$ de extensão por cerca de $1,5 \mathrm{~km}$ de largura, com eixo maior na direção nordeste. Descreveram seus contatos, a noroeste, com granada-biotita-muscovita xistos, localmente feldspáticos, e rochas metabásicas deformadas e intrudidas por granitos porfiríticos e, a sudeste, com rochas gnaissicas, através de uma falha de empurrão com movimentação transcorrente associada, que deformou de tal modo os metapsefitos que se torna difícil a distinção entre estes e os gnaisses locais. Atribuíram aos metapsefitos basais uma deposição provavelmente associada a fluxos de detritos subaéreos, originados de áreas-fonte vizinhas, e retrabalhados em um ambiente costeiro dominado por ondas, incluindo, provavelmente, ondas de tempestade.

Campos Neto (1991) ao analisar a evolução tectônica da porção ocidental da Faixa Alto Rio Grande (Hasui \& Oliveira, 1984) identificou um Cinturão Transpressional exposto entre os segmentos setentrional e meridional da Nappe de Empurrão Socorro-Guaxupé, com caráter transcorrente dextral, que determinou domínios de compressão e de tração, ativos entre 750-600 Ma. A existência de domínios transtracionais, associados a inflexões das faixas de cisalhamento para a direita do sentido do movimento, teriam propiciado a abertura de bacias do tipo pull-apart 
de pequenas dimensões e pouco subsidentes, tardiamente ao evento transpressional principal, que acolheram os sedimentos Eleutério e Pouso Alegre. Considerando, segundo o autor, que estes depósitos ocorrem exclusivamente no domínio da Faixa Alto Rio Grande e que não possuem clastos dos terrenos da Nappe e sim daquela faixa, a abertura das pequenas bacias tectônicas teria precedido a estruturação regional em megantiformes e sinformes e à chegada da Nappe. A estruturação em bacias, para Campos Neto (1991), deve ter ocorrido no período de máximo soerguimento da Faixa, no final da Orogênese Brasiliana, há cerca de $600 \mathrm{Ma}$ e a clivagem ardosiana foi gerada durante a Orogênese Rio Doce (580-490 Ma), quando a Nappe cavalgou sobre os terrenos da Faixa até atingir a borda sudoeste do Craton de São Francisco, com transporte (e compressão) para noroeste, quase ortogonalmente à direção de transporte das zonas de cisalhamento da Faixa. Posteriormente esforços compressivos orientados de E-W a NE teriam causado deformações dúcteis e rúpteis do empilhamento tectônico, gerando amplos dobramentos $\mathrm{N}-\mathrm{S}$, conformando estruturas em domos e bacias e reativações verticais com caráter rúptil nas zonas transcorrentes que rebaixaram o bloco norte em relação ao sul, justapondo ao mesmo nível os terrenos da Nappe e da Faixa.

Fúlfaro et al. (1992) ao abordarem o Paleozóico Inferior do Brasil situaram, em conformidade com Almeida (1967 e 1969), o "estádio de transição" (Cambro-Ordoviciano) como o de esmaecimento dos dobramentos com o predomínio dos falhamentos geradores das bacias intermontanas e magmatismo associado. Destacaram a continentalidade do preenchimento destas bacias, em função da esterilidade fossilifera, mas ressaltaram que tal assertiva poderia ser provisória, uma vez que Ciguel (inf. verbal, apud Fúlfaro et al. 1992) identificara, nos estados de Santa Catarina e Paraná, a presença de icnofósseis em depósitos molássicos. Corroborando com isto, Netto et al. (1992) registraram nas bacias de Camaquã e Santa Bárbara, no Rio Grande do Sul, a presença dos icnogêneros Conchlichnus, Didymaulichnus, Diplocraterion?, Gyrolithes, Intrites, Planolites, Rusophycus, Skolithos e, possivelmente, Cruziana que, segundo os autores, sugerem a existência de ambiente marinho raso para a sedimentação situada entre o Vendiano Superior e o Cambriano. Fúlfaro et al. (1992) aventaram a hipótese de que na borda ocidental da plataforma, instalaram-se aulacógenos preenchidos por sedimentos clásticos continentais associados com depósitos de ingressões marinhas alimentadas pelo oceano proto-andino, como ocorrido na Bacia do Solimões. Possivelmente, segundo os autores, o mesmo ocorrera nas bacias do Alto Tapajós, Parecis e nas bordas W e NW da Bacia do Paraná. Entre o final do estádio de transição da plataforma e o início do estádio de estabilização, estas bacias aulacogênicas foram mutiladas pela erosão que precedeu a instalação e preenchimento das sinéclises paleozóicas. 
Para Basei \& Brito Neves (1992) o Ciclo Tectono-Magmático Brasiliano assumiu características de uma ampla colagem de faixas móveis diversificadas no Neoproterozóico. Do ponto de vista dos autores, o Cambro-Ordoviciano representou o epílogo destes processos tectônicos, magmáticos e sedimentares para toda a Plataforma Sul-Americana (extra-andina), diferenciando-a, neste tempo, dos continentes setentrionais e da faixa andina, que se caracterizaram por um limite brusco Proterozóico-Fanerozóico. A sedimentação eopaleozóica processou-se em bordas cratônicas, às quais associaram-se antefossas molássicas condicionadas por subsidência flexural; sobre placas neoproterozóicas reativadas, às quais associaram-se bacias molássicas vulcano-sedimentares e; em zonas de cisalhamentos, às quais associaram-se bacias do tipo pull-apart, condicionadas por regimes transtracionais. Segundo Basei \& Brito Neves (1992), à medida em que cessaram os processos colisionais dos blocos crustais neoproterozóicos, durante o cambro-ordoviciano a rede de lineamentos atuou como atenuadora (escape) dos movimentos de convergência e, em regiões com predomínio de esforços trativos, foram condicionadas calhas deposicionais, vulcanismo e magmatismo granítico. Como exemplo de bacias pull-apart (associadas às regiões de esforços trativos) os autores apontaram as de Camarinha e Antinha, no Paraná, e, com certas dúvidas, as bacias de Eleutério e Pouso Alegre.

Baldis (1992) considerou que as bacias da transição estiveram diretamente relacionadas com a mobilidade dos grandes lineamentos e aos deslocamentos transcorrentes dos cinturões móveis associados. Sobre o modelo aulacogênico proposto por Fúlfaro et al. (1982) para explicar as origens da implantação da Bacia do Paraná, Baldis (1992) considerou-o perfeitamente coerente com a geração de rifts intracratônicos num contexto de geração de bacias transtracionais relacionadas com o megafraturamento transgondwânico. $\mathrm{O}$ autor invocou para a gênese da sinéclise do Paraná um mecanismo transtracional similar, para o qual na porção norte da Bacia e sobre o Lineamento Transbrasiliano um evento tracional provocou a subsidência do núcleo cratônico (tal como proposto por Cordani et al. 1984), que posteriormente foi recoberto pelos depósitos de transição e paleozóicos.

Riccomini (1993) abordou a origem, evolução e inversão da Bacia do Pico do Itapeva, situada na região leste do Estado. Reafirmou os contatos tectônicos da bacia com as rochas do embasamento proterozóico, através de falhamentos ora de empurrão ora transcorrentes, evolutivos de um a outro, cujas feições estruturais reconstituídas, indicaram embaciamento a partir de um deslocamento sinistral ao longo da Zona de Cisalhamento de Jundiuvira, conformando bacia em forma de "S", do tipo pull-apart. A sedimentação foi contemplada com espessos pacotes, que superam $1350 \mathrm{~m}$ de espessura total, constituídos de metaconglomerados 
polimíticos, metarcóseos, metarenitos e metapelitos, cujas distribuições predominam de sulsudoeste (fácies proximais) para nordeste (fácies distais). Associou os termos rudáceos a fluxos de detritos oriundos de áreas tectonicamente emersas (debris apron) rumo às porções costeiras submersas, envolvendo ambientes de condições litorâneas, de planície de maré e subaquosos sob ação de ondas de tempestades e, mais distalmente, sob ação de correntes de turbidez. A fase de fechamento e inversão da bacia ocorreu como resposta a esforços compressivos, relacionados com atividade tectônica convergente oblíqua correspondente à movimentação lateral direita ao longo da Zona de Cisalhamento de Jundiuvira. Riccomini (1993) atribuiu origem similar para pequena mancha de metassedimentos situada a $4 \mathrm{~km}$ a nordeste do Pico de Itapeva.

Teixeira \& Petri (1993) e Teixeira (1995 e 1996) propuseram para a Bacia de Eleutério uma origem, provavelmente no Eopaleozóico, a partir de movimentação sinistral ao longo da Zona Transcorrente Jacutinga, que em locais de inflexão da sua direção, de ENE-WSW para NE$\mathrm{SW}$, resultou em esforços tracionais e embaciamentos do tipo pull-apart. Os autores concluíram que o preenchimento da bacia ocorreu primeiramente com detritos transportados de NNW para SSE, a partir de leques aluviais coalescentes instalados na borda tectonicamente escarpada noroeste e, num segundo momento, com detritos oriundos de S-SE, associados com borda similar de sudeste. Identificaram nos metassedimentos as fácies sedimentares características das porções proximais de leques aluviais (fluxos de detritos), das porções medianas e distais da planície aluvial (sistema fluvial entrelaçado com retrabalhamento eólico) e fácies lacustres (metapelitos turbidíticos). A bacia foi encurtada a partir da inversão do deslocamento ao longo da zona de cisalhamento de sinistral para dextral, originando então incipiente clivagem ardosiana, basculamento das camadas para NW, fatiamento tectônico de blocos com rotações locais e exposição aos processos erosivos subseqüentes. A imaturidade textural e mineralógica dos sedimentos associada à característica predominantemente episódica da sedimentação, levaram os autores a concluir por condições de clima árido com chuvas torrenciais esporádicas no sítio deposicional, concorrente ou até determinado por uma tectônica sinsedimentar. Teixeira (1995 e 1996) apontou a existência de similaridades litofaciológicas e de mesmas condições paleoclimáticas, e provavelmente paleotectônicas, para a origem e evolução das bacias da transição do Estado e adjacências. Coadjuvou, segundo o autor, com o desenvolvimento destas ao longo da Faixa Ribeira, ingressão marinha do tipo golfo advinda do oceano Proto-Pacífico que avançou, pelo menos, até o Estado de Minas Gerais.

Teixeira (1996) obteve junto ao CPGEO-IG-USP, pelo método K-Ar em rocha total, idade de $530,5 \pm 14,5 \mathrm{Ma}$ para seixo de riólito presente em metaconglomerado polimítico da 
Bacia de Eleutério. O riólito analisado tem matriz fina constituída essencialmente de quartzo e feldspato potássico, com texturas esferulíticas e estruturas fluidais intactas e com fenocristais idiomórficos de quartzo e feldspatos potássicos. Suas características são em muito semelhantes àquelas descritas por Fuck et al. (1967) para os riólitos intercalados aos sedimentos da Bacia Guaratubinha, leste do Paraná. No riólito dos metaconglomerados Eleutério o metamorfismo incipiente caracteriza-se principalmente pela corrosão sobre grãos de feldspatos onde teve lugar a recristalização de sericita e clorita, metamorfismo este totalmente compatível com o da matriz do conglomerado e, de certo modo, com o de toda a bacia. O resultado obtido é coerente com aquele obtido por Hama \& Cunha (1977) em metapelito da Bacia de Pouso Alegre, marcando provavelmente a fase de encurtamento e inversão dessas bacias

Hachiro \& Santoro (1996), a partir da análise de testemunhos de sondagens realizadas pelo IPT na cidade de Cajamar, Grande São Paulo, identificaram em subsuperfície uma seqüência terrígeno-carbonática constituída de calcarenitos, dololutitos róseos (pink dolomites), conglomerados polimíticos com clastos fosfáticos e dolorruditos com clastos de dololutitos que, por ser quase não deformada e anquimetamórfica, distinguia-se das rochas do Grupo São Roque, provavelmente tratando-se de uma unidade do Neoproterozóico-Eopaleozóico. Atribuíram-lhe um desenvolvimento em ambiente plataformal raso, ou de planícies de marés, com águas relativamente agitadas.

Riccomini \& Coimbra (1996), ao reexaminarem as unidades deposicionais da Bacia do Pico de Itapeva, identificaram na unidade intermediária, quatro seqüências deposicionais interpretadas como de ambiente dominado por marés, apresentando estruturas sedimentares heterolíticas (tidal-bundles) separadas por camadas arenosas com estruturas típicas de tempestitos. Esta unidade estaria parcialmente recoberta por conglomerados polimíticos. Com estes novos dados os autores sugeriram que a bacia evoluiu até um embaiamento alongado segundo NE, que permaneceu em condições tectônicas estáveis durante o desenvolvimento da unidade intermediária, sugestiva de freqüentes flutuações do nível do mar, representada por parasseqüências de um grande ciclo transgressivo/regressivo num ambiente dominado por marés e periodicamente interrompido por tempestades. Tal situação permanecera até o início da inversão da bacia, quando os influxos conglomeráticos progradaram sobre a unidade intermediária, provocando o fechamento oceânico, provavelmente no Cambriano. 


\section{CONTEXTO GEOLÓGICO REGIONAL}

O contexto geológico regional em que se inserem as bacias da transição ProterozóicoFanerozóico é totalmente dependente da evolução da Faixa de Dobramentos Ribeira (Hasui $e t$ al. 1975), que teve evolução policíclica remontando, pelo menos, ao Paleoproterozóico. Mas, seriam os eventos relacionados com a amalgamação e consolidação do Megacontinente do Gondwana, ocorridos durante os ciclos geotectônicos Brasiliano-Panafricano (Neoproterozóico-Cambriano), que deixariam suas assinaturas marcantes quanto a rejuvenescimentos isotópicos, metamórficos e deformacionais que seriam, ao final, controladores da arquitetura do arcabouço de um embasamento pretérito, que viria acolher tais depósitos e constituindo, ao mesmo tempo, em suas múltiplas áreas-fonte.

Para tanto, concorreram áreas estáveis cratonizadas e blocos crustais alóctones que se agregavam (docagem) às áreas estáveis do Gondwana, trazendo consigo nesse processo de colagem tectônica restos de bacias oceânicas que se fechavam, a par de processos tectônicos tangenciais, e ora laterais, e de granitogêneses múltiplas (e.g. Campos Neto 1991 e Brito-Neves et al. 1999), caracterizando a Faixa de Dobramentos Ribeira como uma complexa trama de blocos justapostos com variadas assinaturas evolutivas.

Como pode ser visto na Figura 3.1, compilada e modificada de Campos Neto \& Figueiredo (1995) e Campanha \& Sadowski (1999), as bacias da transição ProterozóicoFanerozóico aqui analisadas transgridem sobre terrenos variados que se agregaram diacronicamente ao que viria se constituir o Gondwana Ocidental. Desse modo, as bacias de Eleutério e de Pouso Alegre assentam-se sobre rochas do Cinturão de Dobramentos Alto Rio Grande, cavalgado pelos terrenos alóctones da Nappe de Empurrão Socorro-Guaxupé. As bacias do Pico de Itapeva, de Camarinha, de Cajamar e do Samambaia assentam-se sobre terrenos do Cinturão de Dobramentos Apiaí, situando-se as duas primeiras, respectivamente, nos limites com os terrenos da Nappe de Empurrão Socorro-Guaxupé e da Microplaca Curitiba. A Bacia do Quatis, por sua vez, situa-se sobre paragnaisses da Microplaca Curitiba. As demais bacias, de Castro, Campo Alegre e Guaratubinha, discriminadas na Figura 3.1, também transgridem vários terrenos mas, devido à sua natureza vulcano-sedimentar não foram objeto destes estudos. 


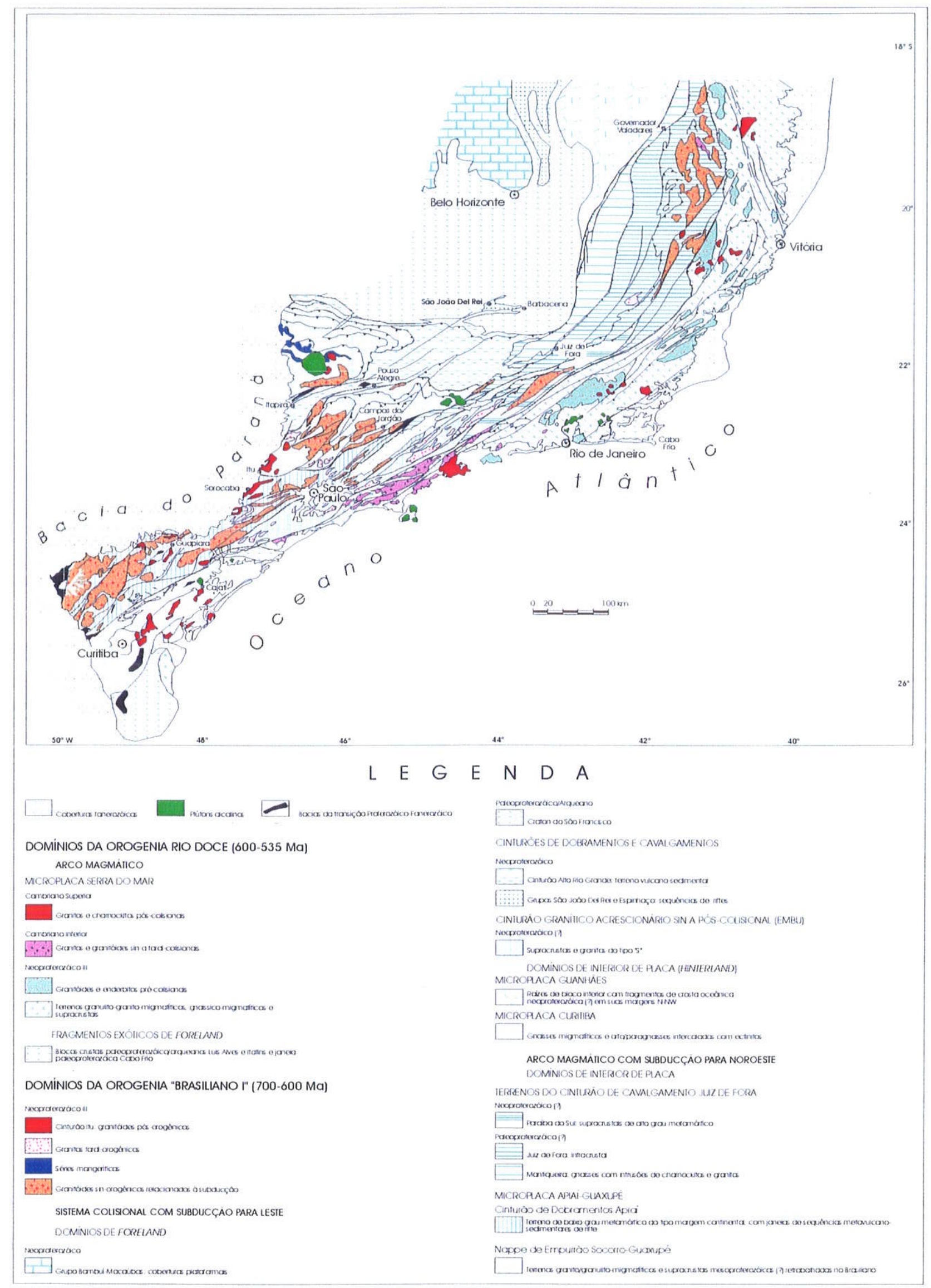

Figura 3.1 - Contexto geológico regional das bacias da transição Proterozóico-Fanerozóico do Estado de São Paulo e adjacências 


\section{GEOLOGIA LOCAL}

\subsection{Bacia de Eleutério}

As primeiras tentativas de empilhamento estratigráfico dos depósitos Eleutério deveramse a Zanardo (1987), que posicionou na base destes os metaconglomerados polimíticos, situados na porção leste da bacia, os quais seriam sobrepostos, rumo a oeste, por metarcóseos e metapelitos, caracterizando-se assim uma diminuição granulométrica geral dos termos de leste para oeste, conforme já apontado por Artur (1980). Em Zanardo et al. (1988) e Zanardo \& Oliveira (1990) a mesma suposição foi sustentada e, ainda, baseando-se na constituição dos extraclastos presentes, como de granitos sub-vulcânicos, granófiros e milonitos de quartzitos, supuseram, também, áreas-fonte localizadas predominantemente a sudeste.

Além da faixa principal de ocorrência dos sedimentos da bacia, com cerca de $16 \mathrm{~km}$ de extensão, orientada para $\mathrm{N} 60^{\circ} \mathrm{E}$, foram analisadas quatro outras ocorrências isoladas de sedimentos. Uma delas situa-se a NE da faixa principal, às margens do rio Mogi-Guaçu. As outras três situam-se, eqüidistantemente, a SW da faixa principal, localizando-se a última destas à margem direita do mesmo rio, já próximo à cidade de Mogi-Guaçu (Figura 4.1.1). Destas ocorrências isoladas, as duas situadas mais a $\mathrm{SW}$ foram cartografadas por Campanha et al. (1982).

A análise faciológica permitiu distinguir associações de fácies que englobam fácies sedimentares com características próprias, não cartografáveis isoladamente por estarem em estreita relação com outras. Estas associações de fácies interrelacionáveis no tempo, espaço e a processos comuns vieram definir partes ou setores de sistemas deposicionais, em parte justapostos, devidos a falhamentos ocorridos em fases pós-inversão da bacia.

Teixeira \& Petri (1993 e 1995) e Teixeira (1995 e 1996) apontaram para o preenchimento da bacia a contribuição de áreas-fonte situadas a noroeste e sudeste, com base nos dados estruturais, estratigráficos e de paleocorrentes. Nesta concepção, os detritos que a preencheram provieram, num primeiro momento, predominantemente de áreas-fonte associadas à borda noroeste, soerguida tectonicamente, e, num segundo momento, de áreas-fonte associadas à borda sudeste da bacia, que iniciou tardiamente atividade ascencional, o que resultou numa progradação de seus depósitos associados sobre aqueles relacionados com as áreas-fonte opostas. 


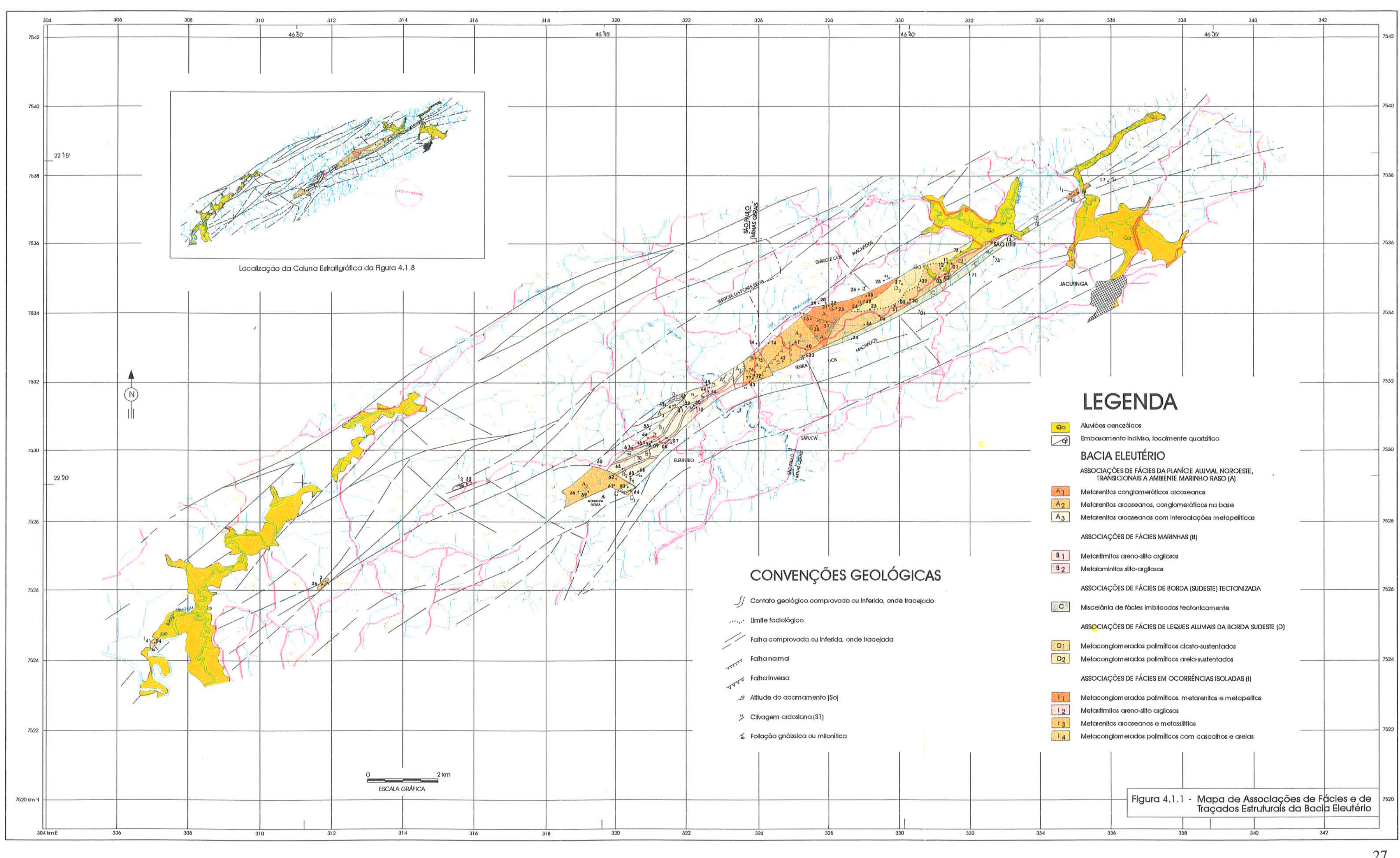


4.1.1. Associações de fácies da planície aluvial noroeste (A)

Associadas à borda noroeste da bacia foram identificadas associações de fácies que compõem sistema de leques aluviais coalescentes, dos quais foram preservados da tectônica póssedimentar restos das porções medianas $\left(A_{1}\right.$ e $\left.A_{2}\right)$ e distais $\left(A_{3}\right)$ da planície aluvial jusante, os quais se justapõem através de falhas. Estas associações ocupam a maior parte da bacia, desde as suas porções nordeste e central, até o extremo sudoeste.

\subsubsection{Associação de fácies $\mathrm{A}_{1}$ : metarenitos conglomeráticos arcoseanos}

É constituída de metarenitos médios a grossos imaturos e conglomeráticos, intercalados com metarenitos médios a grossos e metarenitos médios a finos. Os metarenitos médios a grossos conglomeráticos predominam sobre as demais fácies desta associação. São constituídos de grãos de quartzo e feldspatos subangulosos a subarredondados, com clastos facetados (ventifactos) e com arestas arredondadas de quartzo, quartzitos, milonitos quartzosos, mais raramente de granitóides e, ainda, de intraclastos metapelíticos subangulosos ou arredondados. Estão dispostos em camadas com espessuras de 0,3 a $0,7 \mathrm{~m}$, onde desenvolvem-se estratificações cruzadas acanaladas e planares, tangenciais na base e secantes no topo, de pequeno a médio porte, com seixos dispostos ao longo das lâminas frontais ou concentrados na base dos estratos, geralmente imbricados e com gradação normal. Esta gradação pode evoluir em direção ao topo para metarenitos médios a grossos, feldspáticos, com raros seixos e com estratificações predominantemente planares, e para metarenitos finos a médios, por vezes silto-argilosos e com estratificações e laminações cruzadas. Interrupções nesta seqüência, devidas às bruscas variações de fluxo, desenvolvem estruturas de corte e preenchimento que justapõem, constantemente, as fácies na vertical (Figura 4.1.2).

Localmente intercalam-se nessas fácies pacotes tabulares de até $0,5 \mathrm{~m}$ de espessura constituídos de metarenitos relativamente bem selecionados, com laminação plano-paralela determinada pela alternância de lâminas marrons de metarenitos médios e de lâminas marrom arroxeadas de metarenitos finos, que foram interpretados como lençóis de areia de agradação eólica.

Estruturas de deslizamentos (slumps) são comuns nos metarenitos médios a grossos e poderiam estar relacionadas com eventos sísmicos associados à tectônica sin-sedimentar. 
Figura 4.1.2 - Metarenitos arcoseanos conglomeráticos e metarenitos grossos a finos com estratificações cruzadas de médio porte intercalados, com estruturas de corte e preenchimento (fácies $\mathrm{A}_{1}$, em leito de estrada). A feição oblíqua ao acamamento é devida à ação de motoniveladora.

Figura 4.1.3 - Metarenito arcoseano de granulação média a grossa com intraclastos (destaque) de metapelitos encurvados nas bordas (curled mudflakes). (Fácies $\mathrm{A}_{2}$, flanco noroeste da Serra dos Machados, norte de Sapucai).

Figura 4.1.4 - Seqüências gradacionais de metarenitos médios a grossos arcoseanos a metarenitos finos e metassiltitos com laminações plano-paralelas e cruzadas, interrompidas, com cortes e preenchimentos, por metarenitos grossos conglomeráticos com estratificaçôes cruzadas de médio porte (Fácies $A_{3}$, noroeste de Eleutério). 

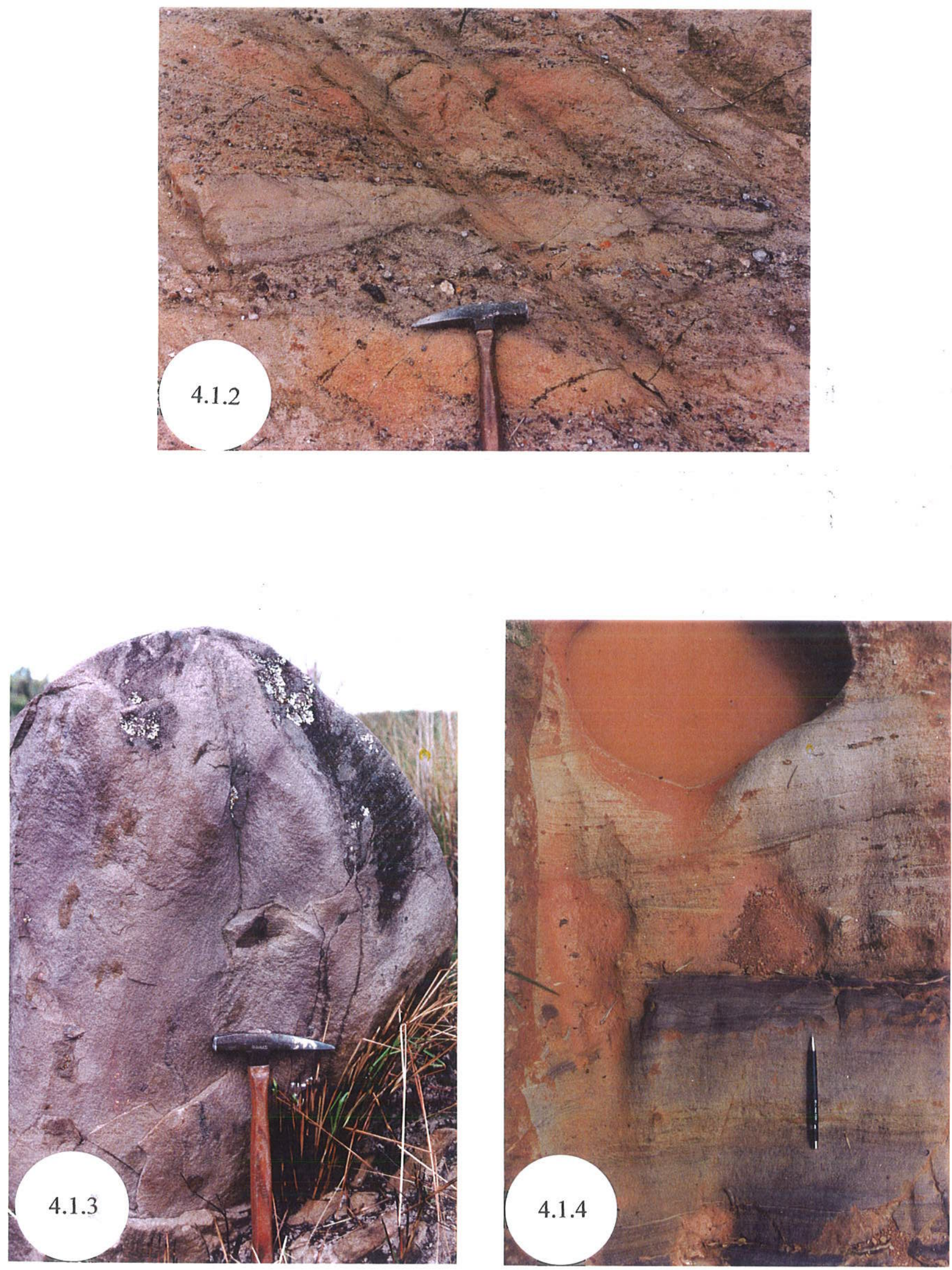
As características gerais da associação de fácies medianas da planície aluvial apontam para o predomínio de depósitos de baixa viscosidade, com fluxos canalizados preponderantes sobre aqueles em lençol, com a atuação concomitante do retrabalhamento eólico.

\subsubsection{Associação de fácies $\mathrm{A}_{2}$ : metarenitos arcoseanos com base conglomerática}

As fácies $\mathrm{A}_{2}$ da planície aluvial, relativamente mais distais que as fácies $A_{I}$, estão representadas por metarenitos médios a grossos arcoseanos com intercalações de metarenitos finos a muito finos arcoseanos silto-argilosos. Assim como ocorre nas fácies $\mathrm{A}_{1}$, localmente pode ser verificada passagem gradual, da base para o topo, dos metarenitos grossos até aqueles muito finos. Em geral predominam truncamentos dos termos grossos a médios sobre os demais, através de estruturas de corte e preenchimento. Estes têm a base conglomerática constituída de seixos quartzo-feldspáticos, quartzíticos, quartzosos e de gnaisses milonitizados, com tamanho médio de 3-4 cm, facetados a 4 faces e com arestas arredondadas (ventifactos). Ocorrem também nesta base conglomerática fragmentos intraclásticos de metapelitos marrom escuros (curled mudflakes) subangulosos centimétricos e com extremidades ligeiramente encurvadas (Figura 4.1.3). Tanto os extraclastos quanto os intraclastos, podem também se distribuir ao longo das lâminas frontais dos estratos cruzados. As camadas de metarenitos grossos a médios variam de 0,5 a $1,5 \mathrm{~m}$ de espessura, com estratificações cruzadas acanaladas e planares de médio a pequeno portes. Aquelas de metarenitos finos silto-argilosos variam entre 0,2 a $0,5 \mathrm{~m}$ de espessura, desenvolvendo ondulações cavalgantes assimétricas com comprimentos de onda até decimétrico e com amplitudes máximas de $2 \mathrm{~cm}$. Estruturas de deslizamentos (slumps) também são comuns nessas fácies.

Entre elas, também localmente, intercalam-se pacotes de areias, interpretadas como de deposição eólica, com até $5 \mathrm{~m}$ de espessura, constituídos de metarenitos relativamente bem selecionados, onde camadas de 1-3 cm de espessura de metarenitos médios, marrom claro, alternam-se com lentes sub-centimétricas de metarenitos finos, marrom arroxeado escuro, que definem estratificações plano-paralela ou cruzada de muito baixo ângulo.

As características gerais das fácies refletem a participação de um sistema fluvial entrelaçado (braided) que se estabeleceu tardiamente aos fluxos de enxurradas (sheetfloods), retrabalhando-os nos estágios finais de predomínio das grandes chuvas, a partir das porções intermediárias da planície aluvial até as suas porções mais distais. Coadjuvou com esses processos a atividade eólica, principalmente nos intervalos entre as grandes inundações, nos períodos de estiagens. A ação do vento retrabalhou os depósitos preexistentes expostos durante 
os períodos de estiagem e os seus depósitos eólicos, nos períodos de retorno das grandes inundações, tiveram poucas chances de serem preservados.

4.1.1.3. Associação de fácies $\mathrm{A}_{3}$ : metarenitos arcoseanos com intercalações metapelíticas (transicionais a ambiente marinho raso)

Nas fácies distais $\left(A_{3}\right)$ da planície aluvial estão representados metarenitos grossos a médios arcoseanos, esbranquiçados a bege, que gradam para metarenitos finos a muito finos silto-argilosos e para metargilitos silto-arenosos. Na base da seqüência os metarenitos grossos a médios têm grânulos angulosos de quartzo e feldspatos e seixos de $1-2 \mathrm{~cm}$ de quartzitos, milonitos quartzosos e raros de granitóides/gnaisses, facetados e arredondados, além de fragmentos intraclásticos de metapelitos marrom escuros, subangulosos e placóides, com 5-10 cm de tamanho e extremidades encurvadas. Os grânulos, seixos e intraclastos podem também se distribuir ao longo das lâminas frontais dos estratos cruzados, acanalados ou planares de médio a pequeno portes, secantes no topo e tangenciais na base e, mais raramente, sigmóides. Este aspecto marca uma gradação normal de uma lâmina à outra subseqüente, além de marcá-la também da base para o topo das camadas com 0,2 a $1,0 \mathrm{~m}$ de espessura. Estas camadas são freqüentemente intercaladas por outras de metarenitos finos silto-argilosos marrom arroxeados de 0,1 a $0,4 \mathrm{~m}$ de espessura, com estratificações cruzadas acanaladas ou planares de médio a pequeno portes, que passam para o topo, gradacional ou abruptamente, a metarenitos muito finos silto-argilosos e para metargilitos silto-arenosos, marrom escuro a arroxeado, com laminações plano-paralelas e cruzadas (Figura 4.1.4).

Os pacotes com predomínio dos metarenitos médios a grossos podem atingir até $20 \mathrm{~m}$ de espessura, com o limite de corte e preenchimento entre cada camada marcado por uma linha de fragmentos intraclásticos de metapelitos. Por outro lado, pacotes com predomínio de termos mais finos podem atingir até $5 \mathrm{~m}$ de espessura, onde o topo de cada sequiência é constituído de metargilito silto-arenoso que, através de estrutura erosiva, às vezes com corte e preenchimento, é sobreposto pelos metarenitos finos silto-argilosos. Além da gradação normal nas camadas, tanto dos termos mais grossos quanto dos mais finos, verifica-se em todo o pacote o desenvolvimento de seqüências com granodecrescência ascendente (fining upward) acompanhadas do espessamento progressivo (thickening) dos termos mais finos intercalados aos mais grossos. Seqüências inversas também ocorrem, onde ao aumento progressivo da granulometria em direção ao topo corresponde o adelgaçamento das camadas dos termos mais finos $\mathrm{e}$ espessamento daquelas de termos mais grossos (thinning e coarsening upward). 
Os registros da atividade eólica nas fácies distais restringem-se à presença de seixos facetados que ocorrem na base conglomerática dos metarenitos grossos, evidenciando que os depósitos eólicos foram transportados até estes sítios, já retrabalhados.

\subsubsection{Associações de fácies de ambiente marinho (B)}

Às fácies marinhas, correspondem metarritmitos areno-silto-argilosos $\left(\mathrm{B}_{1}\right)$ e metalaminitos rítmicos silto-argilosos $\left(\mathrm{B}_{2}\right)$. Ocorrem como pacotes de até $50 \mathrm{~m}$ de espessura entremeados nas fácies distais da planície aluvial descritas acima, com as quais estabelecem passagens gradacionais ou abruptas, quando então de natureza tectônica. Representam depósitos subaqüosos onde predominou a decantação sobre a tração, situados na porção inferior do nível de ondas normais, ou até abaixo deste.

\subsubsection{Associação de fácies $\mathrm{B}_{1}$ : metarritmitos areno-silto-argilosos}

Os metarritmitos areno-silto-argilosos (fácies $\mathrm{B}_{1}$ ) dispõem-se em camadas superpostas, ritmicamente, de $1-10 \mathrm{~cm}$ de espessura, constituídas de areias quartzosas muito finas, silte e argila, marrom amareladas claras, que gradam para o topo para silte areno-argilosos sobrepostos por lâmina sub-milimétrica de material argilo-siltoso marrom escuro. As camadas tabulares apresentam estratificação plano-paralela, ondulações plano-paralelas, ondulações truncantes e cavalgantes (Figura 4.1.5), às quais correspondem leitos com marcas onduladas assimétricas, com cristas retilíneas e, localmente, marcas onduladas lingüiformes.

Mais para a base do pacote, ondulações plano-paralelas e aparentemente cruzadas de baixo ângulo sugerem a participação de ondas de tempestades. É comum entre uma camada e outra estruturas de sobrecarga (chama) e laminações convolutas. Para o topo, gradacionam para laminitos que atingem espessura de cerca de $8 \mathrm{~m}$, semelhantes aos descritos a seguir.

\subsubsection{Associação de fácies $\mathrm{B}_{2}$ : metalaminitos silto-argilosos}

Os metalaminitos constituem monótona seqüência rítmica de lâminas sub-milimétricas a até 5 milímetros de espessura, que da base para o topo evidenciam sutil gradação normal de material silto-argiloso com pequenas frações de areia muito fina para material argilo-siltoso sempre recoberto por película argilosa de coloração marrom mais escuro que a lâmina inferior (Figura 4.1.6). 
Figura 4.1.5 - Metarritmitos areno-silto-argilosos com ondulações cavalgantes. Topo para o alto e paleocorrentes da esquerda para a direita da foto (Fácies $\mathrm{B}_{1}$, noroeste de Eleutério).

Figura 4.1.6 - Gradação normal em laminito (fácies $\mathrm{B}_{2}$, margem esquerda do Rio Eleutério), com foliação metamórfica incipiente oblíqua à laminação, conferida pela orientação de filossilicatos neoformados. No topo de cada lâmina são recorrentes filmes de material muito fino oxidado (porções mais escuras). Nicóis cruzados.

Figura 4.1.7 - No canto superior esquerdo: amostra serrada de metalaminito da associação de fácies $B_{2}$, mostrando microestruturas de sobrecarga, sutil gradação normal (sentido do topo indicado pela seta) e pseudo-concreç̃̃es ferruginosas (circunscritas), tratando-se estas de microfósseis Cloudina riemkeae GERMS 1972 (nível 100m do perfil A da Figura 4.3.15). Ao fundo: na mesma seqüência (Ponto 46), a fotomicrografia exibe um indivíduo em estado de repouso, podendo-se notar a duplicação da parede (indicada pelas setas) para a reprodução assexuada. 

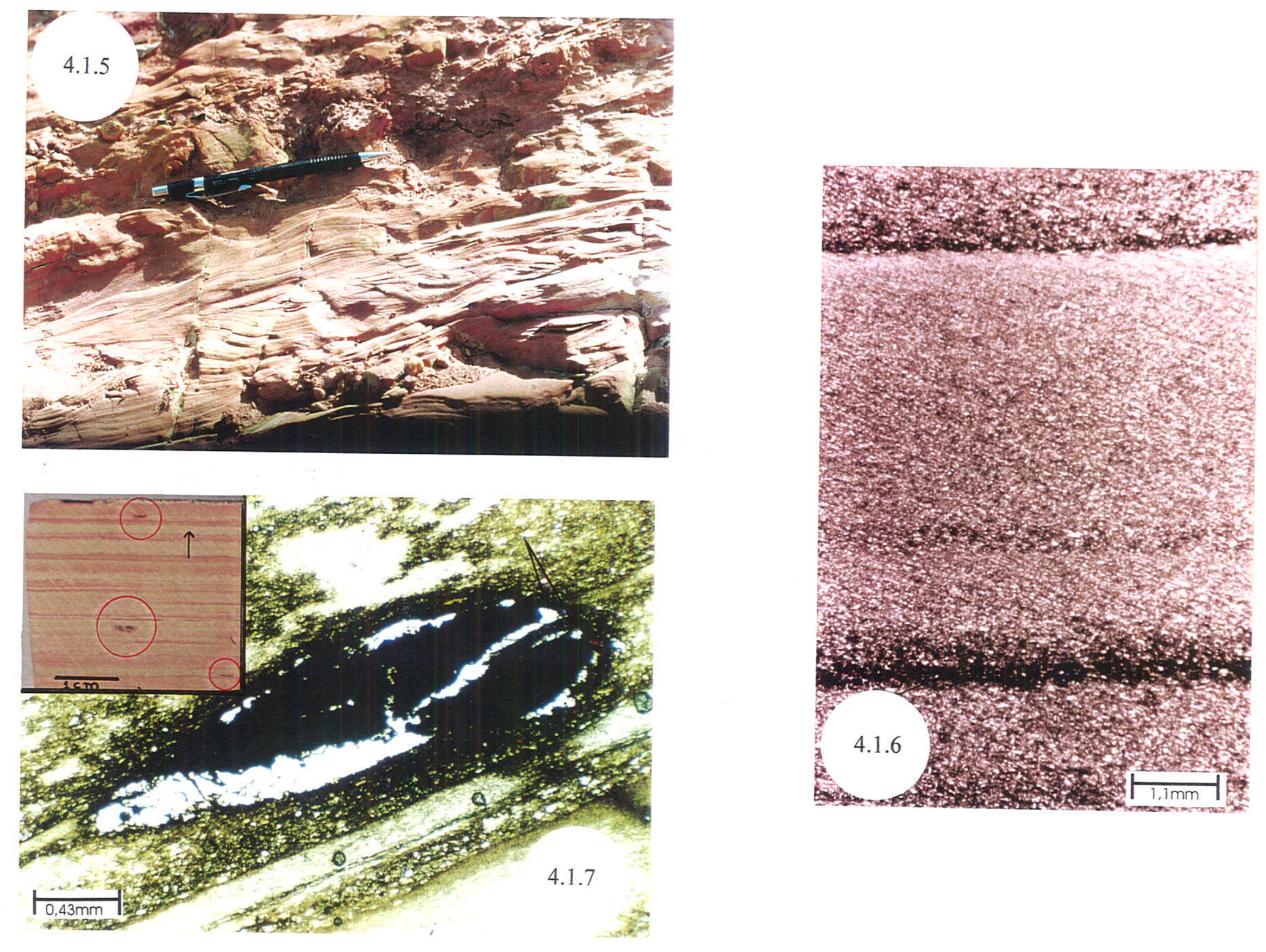
Em determinados níveis dos pacotes que podem atingir até $50 \mathrm{~m}$ de espessura, ocorrem concreções milimétricas com formatos regulares de bastões encurvados (ou "vírgulas") (Figura 4.1.7) achatados segundo a laminação (Teixeira 1996), identificados por Claudio Gaucher e Peter Sprechmann (comun. verbal) como microfósseis pertencentes à espécie Cloudina riemkeae GERMS 1972, também encontrados no Grupo Arroyo del Soldado (Gaucher \& Sprechmann 1999) e no Grupo Corumbá (Zaine \& Fairchild 1985 e Boggiani 1998).

De acordo com Gaucher \& Sprechmann (1999) a ocorrência de Cloudina é condicionada pela boa oxigenação das águas e, conseqüentemente, seu habitat restringia-se a águas marinhas rasas, pobres em matéria orgânica e bem oxigenadas. Apenas localmente e em um nível restrito, foram encontrados pseudomorfos cúbicos de pirita, com 2 a 4 milímetros de aresta, totalmente substituídos por hidróxidos de ferro amorfos, conforme análise por difração de raios- $X$, sugestivos de que também houve condições favoráveis a ambiente redutor durante a deposição ou diagênese.

Várias amostras foram coletadas nesta unidade, com o acompanhamento do Prof. Claudio Gaucher, e encontram-se no Uruguai para processamento paleontológico, incluindo amostras de níveis mais ricos em matéria orgânica para análise de palinomorfos. No perfil do ponto ET-50 (Figura 4.1.8) os metalaminitos têm na porção de topo (últimos $7 \mathrm{~m}$ ) intercalações rítmicas de lâminas de material cinza-esbranquiçado, cujas características mineralógicas e morfológicas dos grãos minerais apontam-nas como provenientes de atividades vulcânicas explosivas ocorridas penecontemporaneamente à sedimentação, correspondendo tais intercalações a cinzas vulcânicas. Foram realizadas baterias de análises com microscópio eletrônico de varredura $(\mathrm{MEV})$ em amostras coletadas neste intervalo. Foram identificados quartzo do tipo sprinter (Figura 4.1.9) que consiste no vidro vulcânico estilhaçado pelo rápido resfriamento, grãos de zircão prismáticos e com facetamento preservado (sem transporte) e grãos de zircão eqüidimensionais (Figura 4.1.10) típicos de magmas resfriados rapidamente (Bohor \& Triplehorn 1993), além de cristais de anfibólios sem feições de retrabalhamento. 


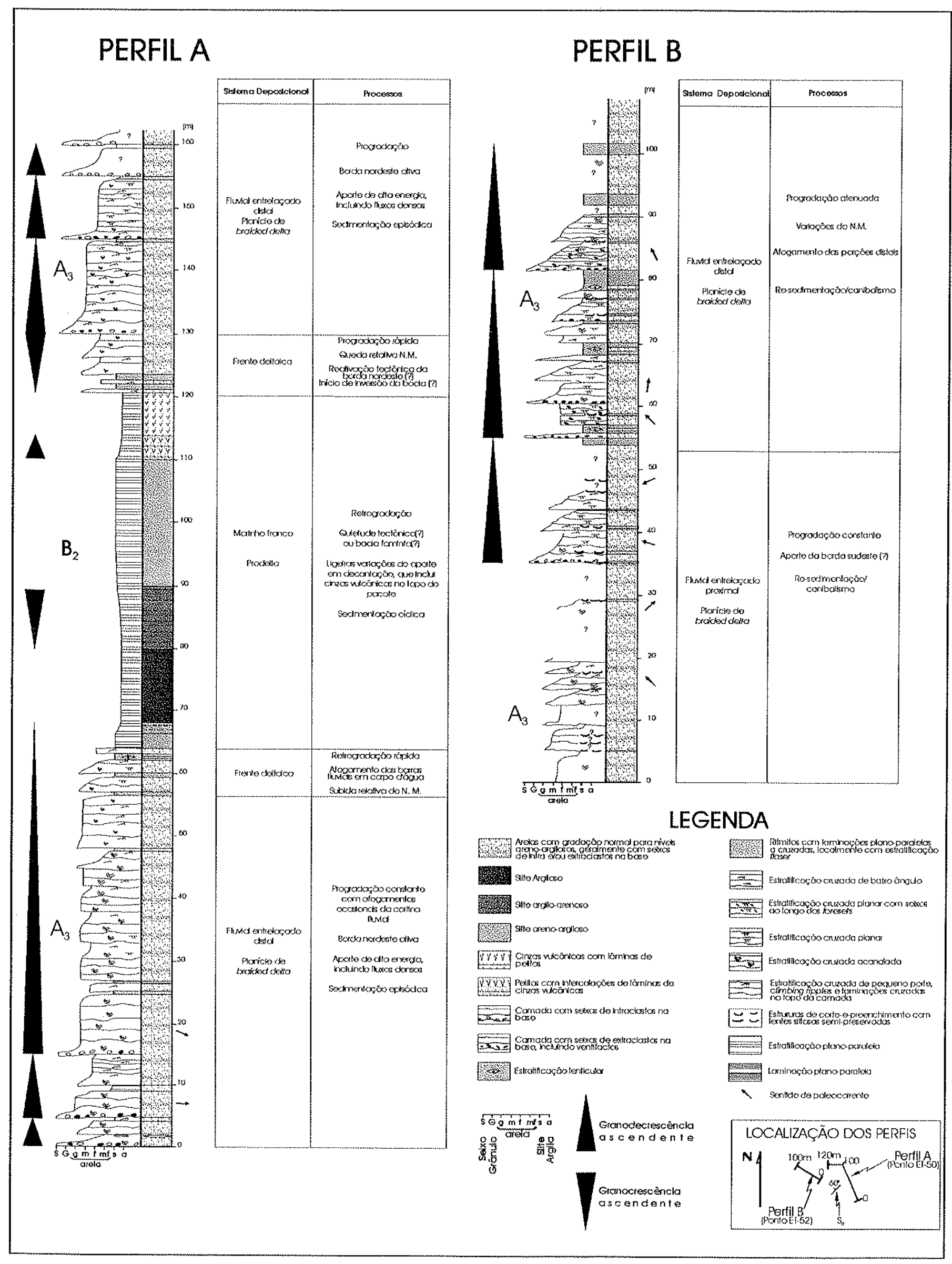

Figura 4.1.8 - Seção colunar entre os pontos ET-50 e ET-52 das unidades $\mathrm{A}_{3} \mathrm{eB}_{2}$ da Bacia Eleutério. 
Figura 4.1.9 - Grão de quartzo do tipo sprinter, associado a resfriamento rápido de magma, presente em intercalações de cinzas vulcânicas em laminitos do ponto ET-50 (nível $118 \mathrm{~m}$ do Perfil A, Figura 4.1.8).

Figura 4.1.10 - Cristal de zircão equigranular de intercalaçôes laminadas em metalaminitos do ponto ET-50, nível $118 \mathrm{~m}$ do Perfil A, da Figura 4.1.8.

Figura 4.1.11 - Metalaminitos com intercalações de metarenitos grossos e conglomeráticos com seixos de quartzitos milonitizados francamente angulosos, semelhantes ao embasamento próximo (Fácies C, flanco noroeste da Serra dos Machados, norte do Bairro Sapucaí). 

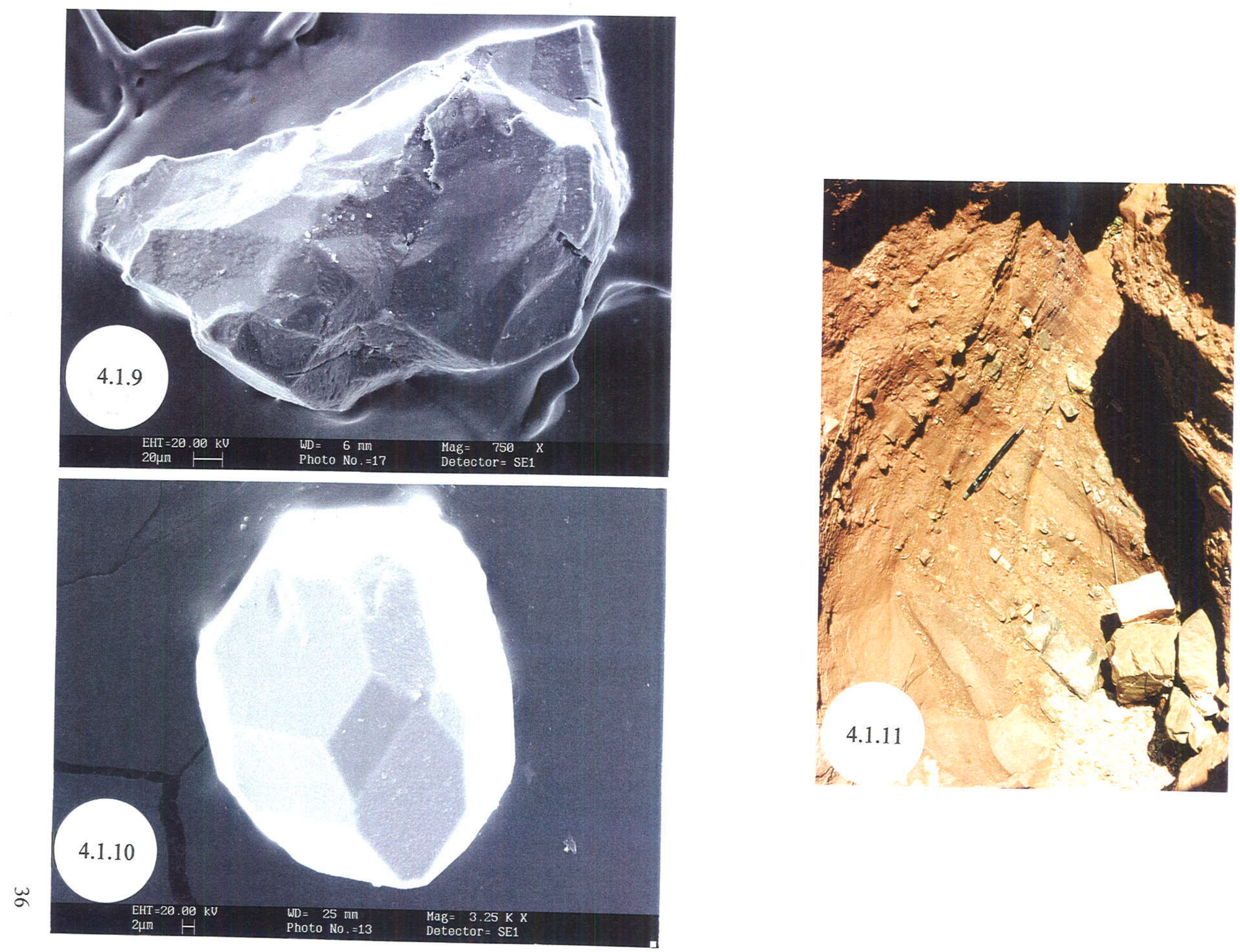


\subsubsection{Associações de fácies tectonicamente imbricadas ao longo da borda sudeste (C)}

Esta associação faciológica ocorre intrinsecamente associada com as bordas da bacia, acompanhando os contatos tectônicos com o embasamento. Ressalta-se que as exposições ao longo dos contatos tectônicos de bordas da bacia não foram verificadas em toda a extensão destas.

Na porção nordeste da bacia, ao longo de sua borda sudeste, após o contato tectônico com o embasamento (predominantemente constituído de quartzitos milonitizados e secundariamente de paragnaisses milonitizados) ocorrem, seqüencialmente (como na entrada do Bairro São Luís), metarenitos arcoseanos com grânulos e seixos que passam, tectonicamente, para metarenitos grossos a médios arcoseanos. Novamente retoma, com contato tectônico, uma faixa de quartzitos (embasamento) com poucas dezenas de metros e, após estes, iniciam-se, provavelmente, os metaconglomerados polimíticos da associação faciológica $\mathrm{D}$. Ao longo da mesma zona de falha, cerca de $2 \mathrm{~km}$ para WSW, a seqüência inicia-se com metarritmitos e metalaminitos, semelhantes aos das associações faciológicas B, situadas quase no outro extremo da bacia. Passam, sem contato observado, para metarenitos médios a grossos, semelhantes aos da associação faciológica $\mathrm{A}_{2}$.

Mais para WSW ainda, esta associação está representada por uma seqüência de metarritmitos silto-argilosos com laminação plano-paralela, com intercalações rítmicas ou não de metarenitos muito finos silto-argilosos com camadas de 1 a $3 \mathrm{~cm}$ de espessura. Pode haver predomínio de um tipo sobre o outro quando as intercalações não são rítmicas. Os metarritmitos silto-argilosos exibem, em determinados níveis, laminações convolutas e, em especial, estruturas provavelmente relacionadas com o escape de fluídos e/ou sobrecarga, que consistem no encurvamento e interrupção de lâminas com concavidades voltadas para o topo, com $3-5 \mathrm{~cm}$ de tamanho. Intercalam-se a estes à medida em que se avança para $\mathrm{N}$, interior da bacia, com ritmicidade não bem definida, camadas centimétricas a decimétricas de metarenitos mal selecionados até conglomeráticos, com seixos e calhaus de quartzitos milonitizados, francamente angulosos, com eixo maior e plano de foliação pretérita paralelizados ou ligeiramente oblíquos ao plano de acamamento sedimentar (Figura 4.1.11). Estes quartzitos milonitizados são idênticos àqueles do embasamento, que dista $50 \mathrm{~m}$ a sul do início destas intercalações. Avançando-se ainda mais para $\mathrm{N}$ volta a ocorrer o predomínio dos metarritmitos sobre os metarenitos com seixos angulosos, até que a seqüência desparece em trecho sem exposição rochosa. Mais à frente, expõem-se intercalações rítmicas de termos metareníticos finos silto-argilosos com outros 
francamente siltomargilosos descrevendo nítida seqüência de coarsening e thickening-upward, até que se estabelecem os metarenitos arcoseanos médios a grossos, semelhantes aos da associação de fácies $\mathrm{A}_{2}$.

Já na zona de falha que limita a borda noroeste da bacia as espessuras dessas "transições"são bem menores. Geralmente ocorre uma faixa de $1,5 \mathrm{~m}$ de material com estrutura de fluxo cataclástico conferida por material fino (fração silte-argila) que envolve porfiroclastos com natureza e granulometria variadas (grânulos a seixos do embasamento e bacia), definindo protomilonitos e milonitos (no conceito de Higgins 1971) que, em seguida, dão lugar aos metarenitos ou metarritmitos das associações faciológicas A e B.

\subsubsection{Associações de fácies do sistema de leques aluviais da borda sudeste (D)}

Associados à atividade tectônica ascencional da borda sudeste, Teixeira \& Petri (1993) e Teixeira (1996) reconheceram como fácies predominantes as de metaconglomerados polimíticos, clasto e areia-sustentados (seguindo classificação proposta por Coimbra et al. 1992). Estas litofácies correspondem às "brechas conglomeráticas com extraclastos", aos "metaconglomerados e metabrechas", às "brechas tectônicas" e "conglomerados brechóides", descritos por Wernick \& Penalva (1974), Artur (1980), Zanardo (1987) e Zanardo et al. (1988) e aos "metaconglomerados brechóides ou não" de Zanardo \& Oliveira (1990). Corresponderiam também à Brecha (tectônica) dos Machados de Wernick \& Penalva (1974) e Rodrigues (1976) que, segundo os autores, limitaria orientalmente os sedimentos da bacia das rochas do Grupo Itapira.

Os metaconglomerados polimíticos têm o arcabouço bimodalmente constitúdo, de um lado, por seixos, calhaus e blocos, estes com até $3 \mathrm{~m}$ de diâmetro, e, de outro lado, por grânulos a até seixos, cuja matriz areno-arcoseana e mal selecionada varia em volume, ora ocupando apenas os interstícios entre os clastos, ora sustentando-os, definindo, respectivamente, aqueles clastosustentados e areia-sustentados (fácies $\mathrm{D}_{1}$ e $\mathrm{D}_{2}$, Figura 4.1.1). Entre os clastos do arcabouço ocorrem fragmentos extrabacinais de gnaisses blastomiloníticos, leucogranitos de granulação grossa, anfibólio gnaisses bandados, quartzitos milonitizados, quartzo de veio, metassilexitos laminados, anfibolitos, granitóides milonitizados, em geral, subarredondados a subangulosos. Como clastos intrabacinais verifica-se no arcabouço fragmentos angulosos e placóides, raramente arredondados, de metassiltitos e metargilitos marrom arroxeados. A matriz é constituída de areia fina a muito grossa, com grãos de quartzo, feldspatos, metapelitos, biotitas, 
muscovitas, epídoto, granada, anfibólios, apatita, titanita e zircão. As camadas, ou fluxos, têm espessuras variáveis entre pouco mais de metro a alguns decímetros, cujas extensões não foram possíveis de ser estimadas. As estruturas sedimentares são de difícil observação, em função das exposições serem, em geral, de dimensões reduzidas. No entanto, foram observadas localmente (Figura 4.1.12) nos termos clasto-sustentados imbricações de seixos e calhaus, gradações normais e inversas, isorientação de clastos na base ou topo de cada camada ou fluxo. Os metaconglomerados areia-sustentados geralmente não exibem organização do arcabouço, salvo gradações normais, observadas localmente. Representam variações laterais ou distais dos conglomerados clasto-sustentados.

Os metaconglomerados polimíticos dispõem-se como dois corpos lenticularizados, segundo direção ENE-WSW, ao longo da porção ocidental da bacia, situando os termos areiasustentados à frente, mais setentrionalmente, dos clasto-sustentados. Representam depósitos de fluxos gravitacionais subaéreos de alta densidade (fluxo de detritos), associados ao sistema de leques aluviais coalescentes instalado ao longo da borda escarpada de sudeste da bacia. A disposição dos fluxos mais fluidos (proximais) à sudeste daqueles mais viscosos (distais) permite inferir paleocorrentes ou fluxos direcionados de SE para NW, baseando-se em Bull (1963). Localmente, apresentam intercalações de lentes arenosas de granulação grossa a fina, com poucos centímetros de espessura, com estratificaçôes cruzadas de pequeno porte e imbricações de clastos que, às vezes, dispõem-se ao longo da lâmina frontal dos estratos cruzados, confirmando o sentido inferido para os fluxos densos.

\subsubsection{Associações de fácies em ocorrências isoladas ( I )}

Além das duas ocorrências isoladas anteriormente descritas por Campanha et al. (1982), duas outras foram identificadas por Teixeira (1996). Uma destas situa-se às margens do Rio MogiGuaçu, a NE do Bairro São Luís (Figura 4.1.1). A outra, situa-se a WNW do morro da Picura, a cerca de $2,5 \mathrm{~km}$ do corpo principal da bacia. A partir desta, a 4,5 $\mathrm{km}$ para $\mathrm{SW}$ ocorrem as duas outras, anteriormente descritas por Campanha et al. (1982), distando entre si de $4,5 \mathrm{~km}$.

\subsubsection{Ocorrência isolada $I_{1}$}

Na ocorrência situada a NE do Bairro São Luís predominam metaconglomerados polimíticos e metarenitos conglomeráticos sobre metarenitos finos e metassiltitos bandados que se lhes intercalam, em cerca de $100 \mathrm{~m}$ de exposição. A SSE fazem contato com quartzitos 
feldspáticos e micáceos milonitizados, fortemente deformados e fraturados. $\mathrm{O}$ acamamento dos epimetamorfitos tem atitude $\mathrm{N} 50^{\circ} \mathrm{E} 65^{\circ} \mathrm{NW}$ e topo para NW.

Os metaconglomerados, que fazem contato diretamente com as rochas do embasamento, podem ser clasto a areia-sustentados com passagens gradacionais para metarenitos seixosos ou conglomeráticos. Seixos de quartzitos milonitizados arredondados a subarredondados, geralmente oblatos, predominam no arcabouço dos metaconglomerados, sobre outros de granitóides milonitizados e de feldspatos. Além destes ocorrem, mais raramente, intraclastos de dimensões variadas de metassiltitos argilosos com grânulos de feldspatos angulosos e de quartzo. Os seixos de milonitos tem em média $2-3 \mathrm{~cm}$ de tamanho, podendo atingir até $8 \mathrm{~cm}$. Os de feldspatos variam de 1 a $4 \mathrm{~cm}$ e são, geralmente, angulosos.

Nos termos clasto-sustentados existe nítido imbricamento entre os seixos, com a matriz arenosa grossa com grânulos de quartzo e feldspatos ocupando os interstícios entre estes. Naqueles areia-sustentados a matriz é idêntica e os seixos dispõem-se com seus eixos maiores razoavelmente alinhados obliquamente ao acamamento, definindo estratificações cruzadas de baixo ângulo. Localmente definem estratificações sigmóides com $0,6 \mathrm{~m}$ de comprimento e $0,1 \mathrm{~m}$ de espessura (Figura 4.1.13). As passagens de uns para outros podem se dar na lateral e vertical, com o aumento da relação de volume matriz/arcabouço, quando se estabelecem os termos areiasustentados. As gradações normais podem alcançar até termos arenosos grossos arcoseanos com grânulos e seixos.

Intercalam-se nestes termos conglomeráticos, metarenitos finos a médios siltosos com grânulos e seixos. Os metarenitos organizam-se em camadas de 2 a $5 \mathrm{~cm}$ de espessura, com estratificações plano-paralelas e cruzadas de pequeno porte, que definem leitos com marcas onduladas assimétricas com comprimentos de ondas de até $20 \mathrm{~cm}$, ou como ondas truncantes. Os metassiltitos argilosos, ocorrem sempre diretamente associados com os metarenitos, como intercalações, com passagens relativamente bruscas, apresentando laminações plano-paralelas, cruzadas ou ondulações cavalgantes. No topo destes termos mais finos é comum a presença de estruturas de sobrecarga, como "chama", quando sobrepostos principalmente pelos metaconglomerados.

Após cerca de $40 \mathrm{~m}$, rumo ao topo, desde as rochas do embasamento, a seqüência de intercalações com predomínio dos metaconglomerados, paulatinamente ganha intercalações mais espessas de metarenitos e metassiltitos até que estes predominam no decorrer de algumas dezenas de metros, estabelecendo-se uma sucessão rítmica de metassiltitos com metarenitos 
Figura 4.1.12 - Metaconglomerado polimítico clasto-sustentado com seixos e calhaus predominantemente de quartzitos milonitizados, tenuemente imbricados ao longo das camadas decimétricas, com sutil gradação normal (para à esquerda), determinando paleocorrentes do alto para baixo da foto (fácies $D_{1}$, leste do Morro da Picura). A base da foto tem aproximadamente 1,5 metros.

Figura 4.1.13 - Metaconglomerados com predomínio de seixos quartzo-feldspáticos milonitizados intercalados por metarenitos finos e metapelitos. Em destaque o desenvolvimento de estratificações sigmóides de médio porte nos metarenitos finos (canto direito inferior) e nos metaconglomerados (sob a escala) (Ocorrência $\mathrm{I}_{1}$, margem esquerda do Rio Mogi-Guaçu, nordeste do Bairro São Luís).

Figura 4.1.14 - Metaconglomerado clasto-sustentado, constituído de cascalhos arredondados a subarredondados de riólitos (1), quartzitos róseos (2), metabasitos (3), leucogranitos (4), etc. (Ocorrência isolada $\mathrm{I}_{4}$ ). 

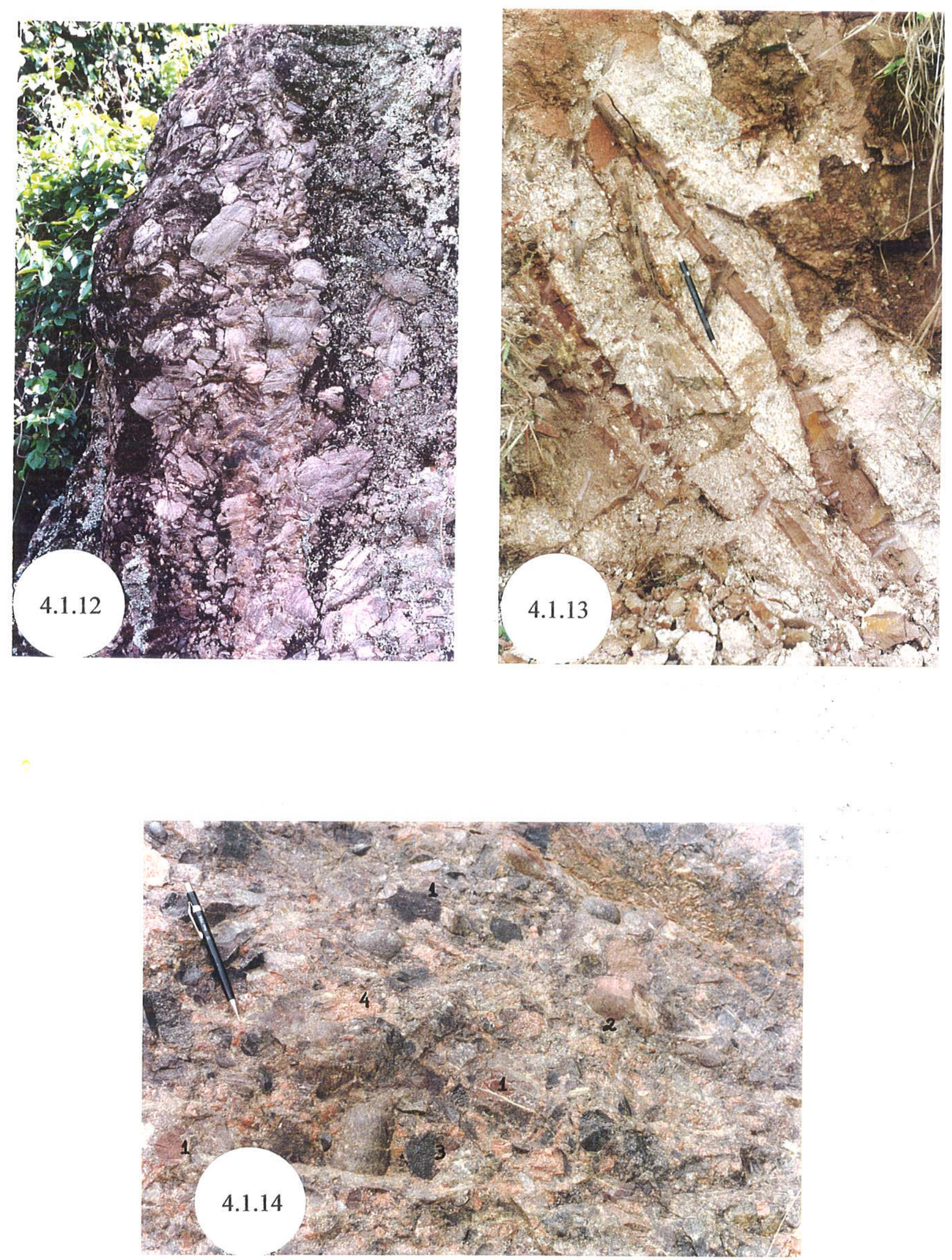
finos com exposições muito precárias à observação detalhada. Nitidamente, ocorre uma seqüência de fining e thinning-upward.

As paleocorrentes medidas nestas fácies indicam fluxos de SE para NW, indicando sua associação com áreas-fonte de sudeste.

\subsubsection{Ocorrência isolada $\mathrm{I}_{2}$}

A outra ocorrência isolada, identificada neste trabalho, situa-se a cerca de $2,5 \mathrm{~km}$ a sudoeste do corpo principal da bacia, teve observação restrita ao leito de pequena estrada vicinal. Constitui-se de metarenitos muito finos silto argilosos, com laminação plano-paralela, definindo lâminas milimétricas alternadas ritmicamente de cores marrom, bege e cinza. $O$ acamamento tem atitude N60E 60SE, sem definição de topo e base.

\subsubsection{Ocorrência isolada $I_{3}$}

A ocorrência imediatamente a $4,5 \mathrm{~km}$ a sudoeste da anterior foi identificada por Campanha et al. (1982). Exibe metassiltitos marrom arroxeados e metarenitos de granulação grossa a média, arcoseanos, embutidos tectonicamente entre gnaisses de composição granítica e quartzitos, ambos milonitizados e intensamente fraturados a brechados. O acamamento está paralelizado à foliação milonítica com atitude N45E 76SE, sem a definição de topo e base nesta lente.

\subsubsection{Ocorrência isolada $\mathrm{I}_{4}$}

Esta última ocorrência isolada está situada no extremo $\mathrm{SW}$, margem direita do rio MogiGuaçu, constitui-se de cerca de $50 \mathrm{~m}$ de exposição de rocha pouco alterada a sã, destacada pelo corte da estrada vicinal que liga Itapira a Mogi-Guaçu. Campanha et al. (1982) haviam identificado esta ocorrência a partir de blocos às margens do Rio Mogi-Guaçu.

Constituem-na metaconglomerados polimíticos clasto a areia suportados, com raras intercalações arenosas delgadas. $\mathrm{O}$ arcabouço dos metaconglomerados é constituído de seixos com tamanho médio de $3-5 \mathrm{~cm}$ e, em menor proporção, de calhaus que podem atingir até $15 \mathrm{~cm}$, com $10 \mathrm{~cm}$ em média. Os clastos são constituídos por quartzitos róseos, quartzitos de veios, anfibolitos, granitos róseos de granulação média a fina, anfibólio granitos cinza-escuro de granulação fina, leuco-granitos róseos de granulação grossa, muscovita granitos cinza-escuro de granulação média, metacherts laminados (jaspelitos), rochas riolíticas afaníticas com fenocristais 
sub-centimétricos de feldspatos potássicos e de quartzo, milimétricos, arredondados, de coloração marrom tijolo a marrom escuro e seixos de feldspatos róseos, além de seixos intraclásticos de metassiltitos e de metarenitos marrons com grânulos. Os seixos são arredondados a bem arredondados, excetuando-se aqueles jaspelíticos laminados e de feldspatos, que são subarredondados a angulosos. É muito comum a presença de seixos facetados (com 4 faces), mas predomina tendência à esfericidade (Figura 4.1.14).

A matriz é arenosa grossa com grânulos de natureza variada, feldspática a arcoseana e geralmente ocupa os interstícios entre os clastos, perfazendo por volta de $5 \%$ do volume da rocha. Esta proporção pode ser aumentada para até cerca de $20 \%$, definindo porções delgadas $(10-15 \mathrm{~cm})$ de areia (matriz) suportadas, correspondendo a uma seqüuência com gradação normal. Localmente esta gradação pode evoluir bruscamente, ou ser truncada, por lentes arenosas grossas com grânulos e seixos, com 10 a $20 \mathrm{~cm}$ de espessura, que, às vezes, desenvolve estratificações cruzadas de pequeno porte destacadas por minerais pesados dispostos nas lâminas frontais dos estratos. De outro modo podem se apresentar como lentes maciças. O acamamento, definido pela intercalação arenosa tem atitude $\mathrm{N} 32^{\circ} \mathrm{W} 80^{\circ} \mathrm{SW}$, com topo para NE.

Um dos seixos de riólito presente nesses metaconglomerados foi analisado junto ao CPGEO-IG-USP, pelo método K-Ar em rocha total, fornecendo idade de $530,5 \pm 14,5 \mathrm{Ma}$ (Teixeira 1995). O riólito analisado tem matriz fina constituída essencialmente de quartzo e feldspato potássico, com texturas esferulíticas e estruturas fluidais intactas e com fenocristais idiomórficos de quartzo e de feldspatos potássicos (Figura 4.1.15). A idade obtida marca, provavelmente, o resfriamento pós-pico metamórfico-deformacional relacionado com a inversão e encurtamento da Bacia de Eleutério.

Teixeira et al. (1999) realizaram datação U/Pb monocristal, pelo método SHRIMP, na Australian National University, em 4 cristais de zircão selecionados de concentrado da amostra ET-54-11, seixo riolítico escolhido entre vários de metaconglomerado desta ocorrência isolada. Os resultados analíticos e o diagrama concórdia $\mathrm{U} / \mathrm{Pb}$ podem ser vistos na Figura 4.1.16. Obtevese idade média de $617 \pm 13 \mathrm{Ma}$ (critério $2 \sigma$ ), com máxima em $635 \pm 14$ Ma e mínima em $606 \pm$ 13Ma. Esta última, considerando a confiabilidade do método e contaminação de encaixantes (micro-encraves) verificada no exame de seções delgadas, é a mais plausível de marcar idade máxima para o início da sedimentação.

Poder-se-ia, assim, estabelecer, a partir das idades radiométricas obtidas nos seixos rióliticos do metaconglomerado da ocorrência isolada $I_{4}$, um limite inferior de aproximadamente 
606 Ma para o início da sedimentação na Bacia de Eleutério e um limite superior para o final da deposição ao redor de $530 \mathrm{Ma}$, quando ocorreu a inversão e encurtamento da bacia.

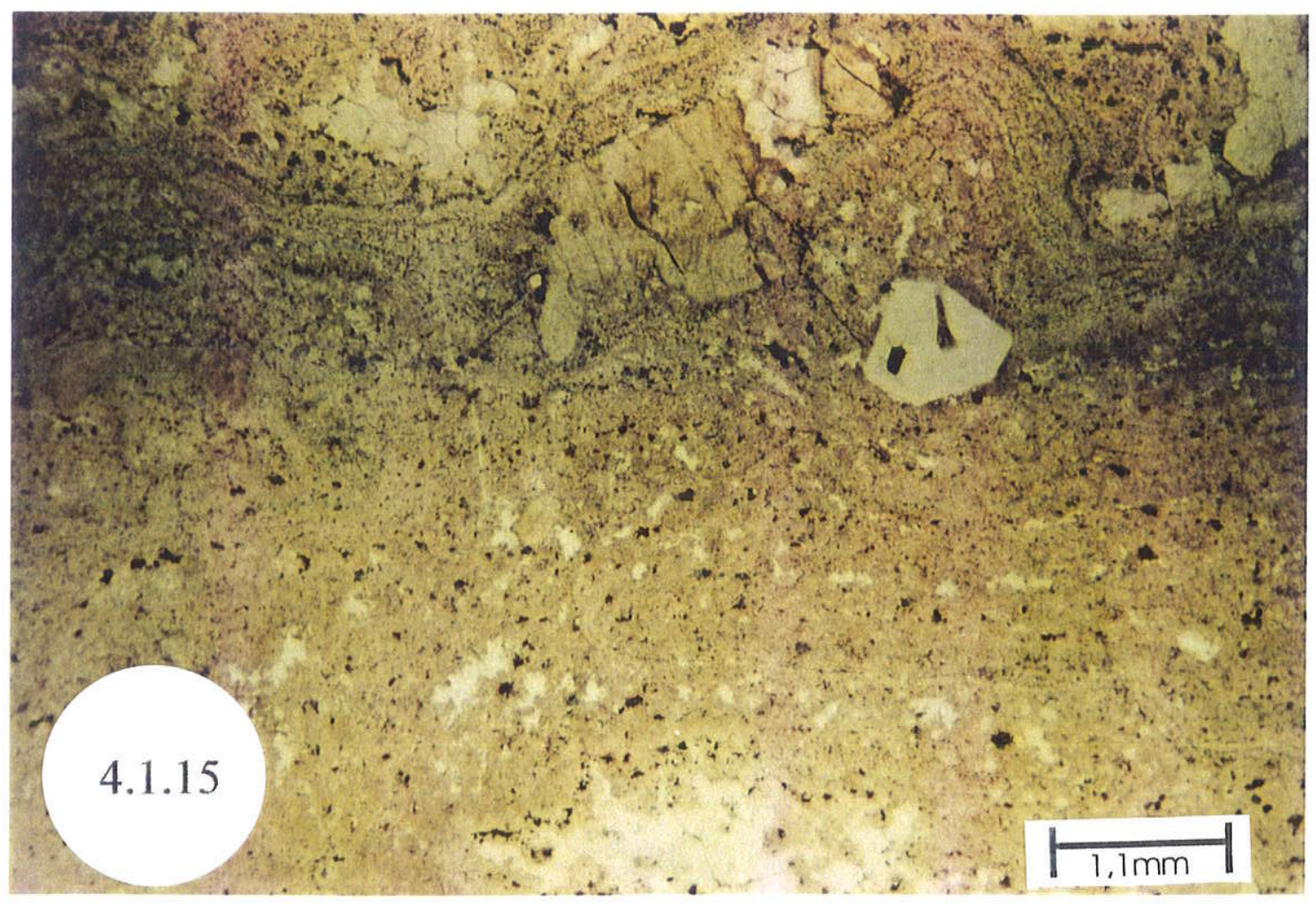

Figura 4.1.15 - Estrutura fluidal em seixo de rocha riolítica, onde se destacam fenocristais de feldspatos potássicos e de quartzo euhedrais com embainhamentos, em meio à matriz afanítica essencialmente quartzo-feldspática, (Ocorrência isolada $\mathrm{I}_{4}$, próxima à Mogi-Guaçu). Nicóis descruzados. 


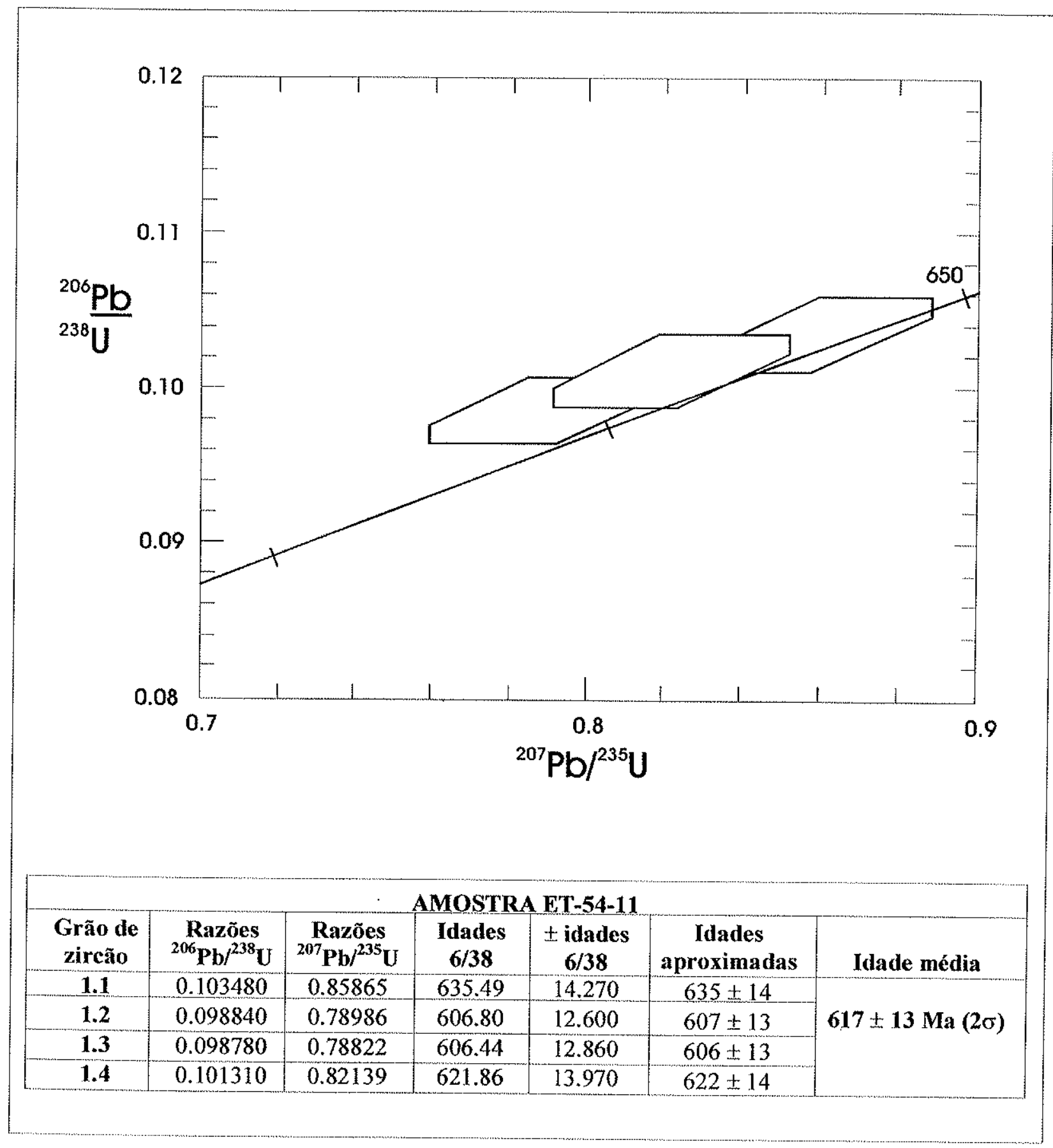

Figura 4.1.16 - Resultados analíticos e diagrama concórdia U/Pb, obtidos pelo método SHRIMP em monocristais de zircão de seixo riólítico de metaconglomerado da Bacia Eleutério. 


\subsubsection{Paleocorrentes}

A Figura 4.1.17 mostra os dados de paleocorrentes obtidos por Teixeira (1995), reinterpretados. Verifica-se que nas associações de fácies $A_{1}$ e $A_{2}$ (fácies medianas de leques aluviais) os fluxos predominantes são de NW para SE, com dispersões mais acentuadas na associação $A_{2}$ (relativamente mais distal que $A_{1}$ ), provavelmente devidas às influências do nível de base (variações do nível do mar) que proporcionaram maior sinuosidade aos canais dos rios entrelaçados. Em $\mathrm{A}_{3}$, apesar dos dados serem mais escassos em cada afloramento, nota-se a maior dispersão dos fluxos, quando não até a inversão do sentido destes (pontos 50 e 52), o que sugerindo nas porções de afogamento (braided delta) a participação de correntes de marés.

Nas associações conglomeráticas (D) os fluxos foram predominantemente inferidos a partir das características dos depósitos, situando-se os metaconglomerados matriz-sustentados à jusante (NW) dos clastos-sustentados (SE). Adicionalmente, nos pontos 16 (ocorrência isolada $I_{1}$ ) e 64 (associação faciológica $D_{1}$ ) estratificações cruzadas de pequeno e médios portes confirmam fluxos de SE para NW. No ponto 16 (ocorrência isolada $I_{1}$ ), cristas assimétricas indicaram fluxos concordantes aos dos arenitos e conglomerados.

$\mathrm{Na}$ associação B1 (metarritmitos) as assimetrias em marcas onduladas com cristas retilineas a sub-retilíneas indicam fluxos de NNW para SSE nos pontos 52 e 48 e fluxos de SE para NW no ponto 78 , evidenciando em porções de foreshore a participação de correntes de marés (com tempestades?) em regiões de barra de desembocadura.

Desse modo, os dados de paleocorrentes, associados às demais feições estratigráficas, indicam que o preenchimento da Bacia de Eleutério ocorreu com a participação de áreas-fonte situadas a NW, num primeiro momento, e com áreas-fonte situadas a SE, num segundo momento, talvez já no início da inversão da bacia. 


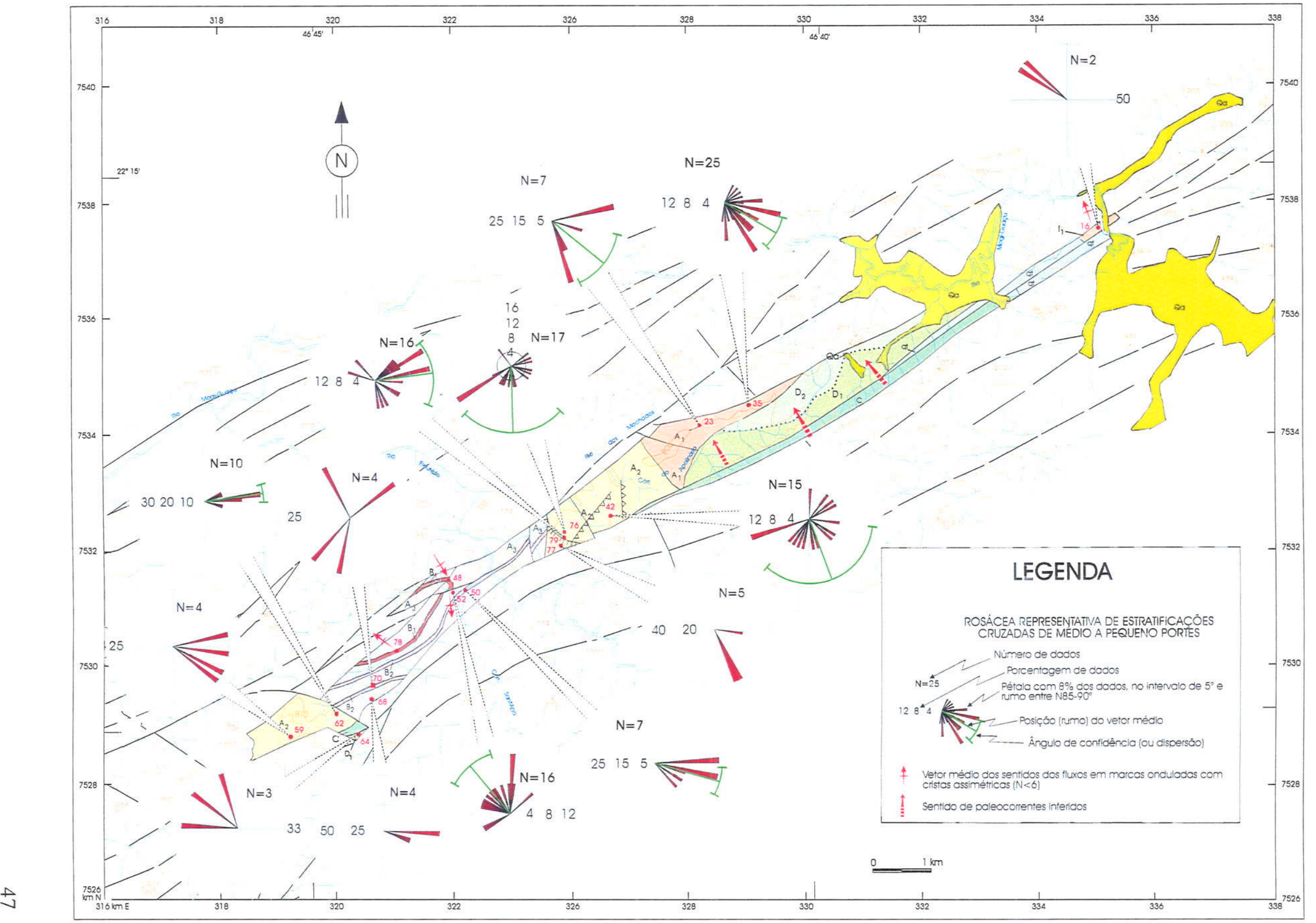

Figura 4.1.17 - Paleocorrentes da Bacia de Eleutério 


\subsubsection{Geologia Estrutural}

$\mathrm{O}$ acamamento reliquiar $\left(\mathrm{S}_{0}\right)$, grosso modo, é concordante com o trend da Zona de Cisalhamento de Jacutinga, que, também, intercepta o embasamento na qual circunscreve-se a Bacia de Eleutério. O acamamento, com mergulho médio de $65^{\circ}$ para $\mathrm{NW}$, é cortado por uma clivagem ardosiana incipiente $\left(\mathrm{S}_{1}\right)$ com mergulhos médios sub-verticais para sul e com direções sub-concordantes com $\mathrm{S}_{0}$, variáveis de até cerca de $10^{\circ}$ para NE ou SE (Figura 4.1.18). As relações de $S_{0}$ com $S_{1}$ indicam vergência para sul, entretanto inexistem dobramentos cilíndricos associados. Dobras mesoscópicas locais associam-se a padrões cônicos originados em eventos pós-inversão da bacia (Teixeira 1995). Este autor sugeriu que a clivagem ardosiana foi gerada durante a inversão e encurtamento, a partir de um cisalhamento rúptil-dúctil associado à movimentação lateral direita (destrógira) da ZC Jacutinga, quando ocorreu a neoformação de filossilicatos (sericita, clorita, illita, etc) dentro de processo de dissolução por pressão, que os isorientou (mica beards) ao longo das fraturas Y, R (de Riedel) e P (de Tchalencko \& Ambraseys 1970).

Tardiamente à inversão da bacia, reativações da zona de cisalhamento impuseram 2 outras movimentações laterais, com componentes verticais, originando numa primeira fase movimentação lateral esquerda (sinistrogira) com vetores máximos compressivos orientados segundo NE-SW e, numa segunda fase, movimentação lateral direita, com vetores máximos compressivos orientados segundo NNW-SSE. 


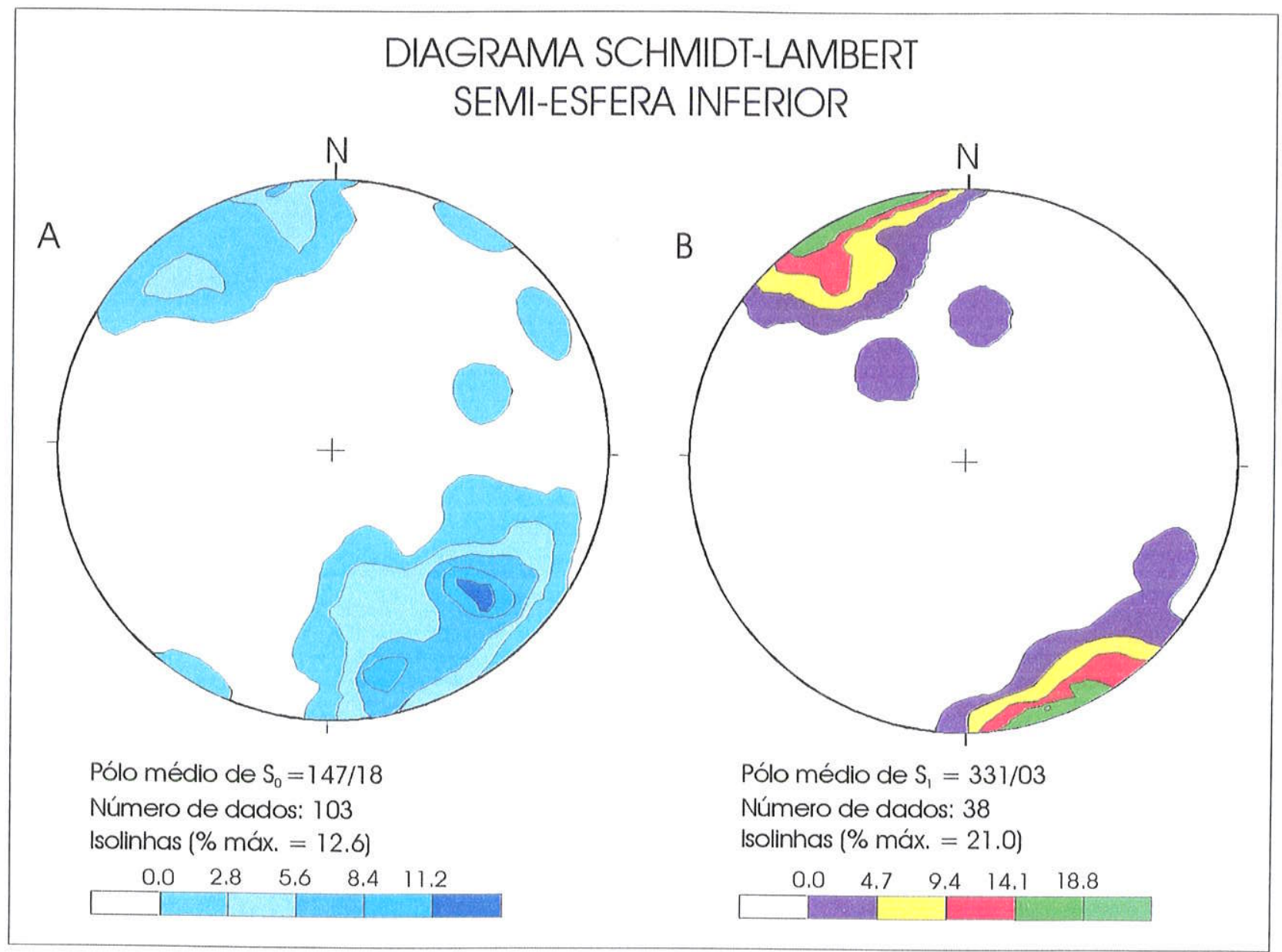

Figura 4.1.18 - Estereograma das atitudes do acamamento reliquiar $\left(\mathrm{S}_{0}\right)$ e da clivagem ardosiana $\left(\mathrm{S}_{1}\right)$ obtidos a partir de medidas na Bacia de Eleutério. 


\subsection{Bacia do Pico de Itapeva}

Os depósitos da Bacia do Pico de Itapeva ocorrem nos limites escarpados do Planalto de Campos do Jordão, a sudeste da cidade de mesmo nome, no Estado de São Paulo. A bacia remanescente tem formato lenticular com cerca de $14 \mathrm{~km}$ de comprimento ao longo do eixo maior, com orientação NE-SW, e 1,7 km do eixo menor, orientado segundo NW-SE. Os seus limites são controlados por falhas, ramificações das zonas de cisalhamentos de Jundiuvira e Buquira, as quais convergem entre si na região e se caracterizam por zonas com planos de falhas empinados, cuja evolução policíclica alcançou o Cenozóico (Riccomini 1989 e Hiruma 1999).

Em quase sua totalidade os depósitos guardam as estruturas singenéticas bem preservadas e, invariavelmente, as camadas têm polaridade estratigráfica normal, ou seja, com topo para SE e base para NW. Desse modo, a estruturação em sinclinal isoclinal com plano axial mergulhante para sudeste, como sugerida por Juliani et al. (1990) e Riccomini (1993), não se confirmou. Conseqüentemente, as unidades de base são aquelas situadas na borda noroeste da bacia, onde predominam depósitos metapelíticos, e não aquelas da borda oposta sudeste, constituídas por metaconglomerados polimíticos, como sugeriram os autores.

Nesta bacia foram identificadas 4 unidades litoestratigráficas, que correspondem, cada uma delas, a uma associação de fácies sedimentares, as quais, em conjunto, permitiram identificar ambientes, sistemas deposicionais e/ou partes destes.

Os depósitos preservados somam espessura aproximada de $1720 \mathrm{~m}$. Os metarritmitos, situados na base da bacia, perfazem cerca de $130 \mathrm{~m}$ de espessura. Estes são sobrepostos de modo erosivo por metarenitos com estratificações cruzadas de baixo ângulo com espessura ao redor de $690 \mathrm{~m}$. Para o topo, de modo transicional, os metarenitos são sucedidos por pacote de metaconglomerados polimíticos finos com espessura aproximada de $450 \mathrm{~m}$ que, gradativamente, dão lugar a metaconglomerados polimíticos grossos cujo pacote atinge espessura de cerca de 450 m, quando se encerra a seqüência. A seguir, da base para o topo, essas unidades serão descritas:

\subsubsection{Metarritmitos com metaconglomerados e metarenitos intercalados}

Ocorrem como delgada lente na borda noroeste da bacia, em sua porção central (Figura 4.2.1). Limitam-se tectonicamente com o embasamento constituído por granitos do tipo Bragança Paulista, Suíte Serra Preta (Morais 1999 e Santoro 1998). 


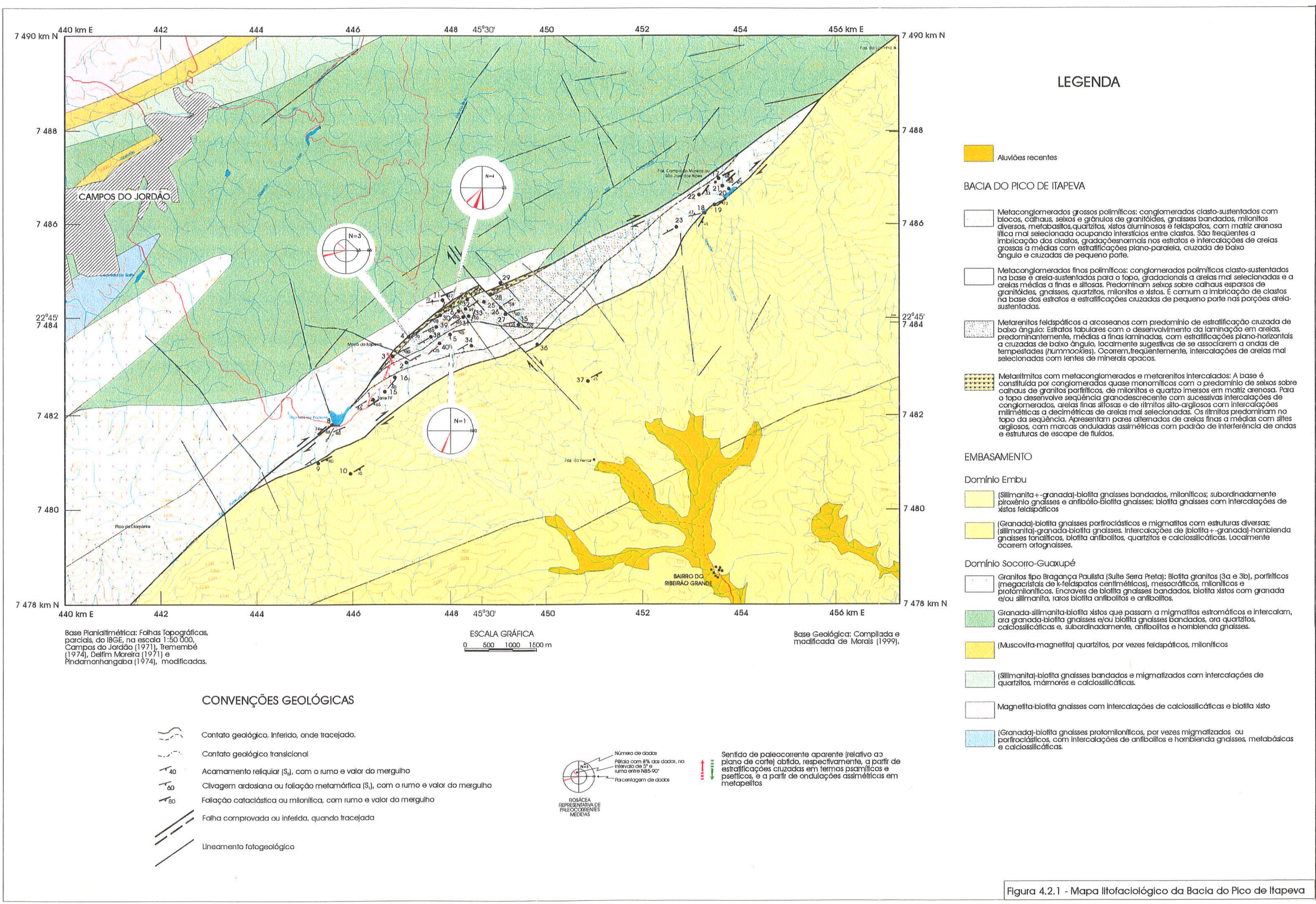


$\mathrm{Na}$ base ocorrem, em cerca de $8-10 \mathrm{~m}$, conglomerados quase monomíticos, onde predominam seixos (raros calhaus) arredondados de granitos porfiríticos (com megacristais de feldspatos em matriz rica em biotita e anfibólios). Seixos de milonitos quartzosos e de quartzo ocorrem, subordinadamente, em meio à matriz arenosa. Em direção ao topo (SE) intercalam-se areias finas com espessuras de até $5 \mathrm{~cm}$ que, gradativamente, dão passagem a areias finas siltosas e, finalmente, a ritmitos silto-argilosos. Estes ritmitos caracterizam-se por alternâncias (pares) de siltitos argilosos acinzentados com arenitos finos a médios ou até finos siltosos amarelados a bege, laminados (1 a $5 \mathrm{~mm}$ ). Intercalações conglomeráticas podem ser também recorrentes nos ritmitos, gradacionais ao topo para areias finas a médias. Esta seqüência atinge cerca de $65 \mathrm{~m}$ de extensão, em planta, quando está sobreposta por outra de $40 \mathrm{~m}$ constituída por areias finas a muito finas, com estratificação/laminação aparentemente plano-horizontal e, às vezes, aparentam ser maciças, com cores marrom avermelhado a bege esbranquiçado, marcada por níveis lentiformes ricos em opacos. $\mathrm{Na}$ base, ocorre tênue nível conglomerático que, gradualmente, dá lugar às areias.

O pacote é sucedido por conglomerados, areias e ritmitos, sempre nessa seqüência rítmica por cerca de $10 \mathrm{~m}$, encerrando com ritmitos no topo. No ponto PI-03, está bem exposto o final desta seqüência que fecha a unidade litoestratigráfica (Figura 4.2.2).

Nos ritmitos são comuns estruturas de escape de fluidos que, freqüentemente, interceptam vários pares previamente depositados, ocasionando encurvamentos nas lâminas pelíticas, rompidas em várias direções. Muito comuns também são pequenas dobras ocasionadas por deslizamentos (slumps) que complicam ainda mais o entendimento dos processos sinssedimentares. Na base de uma seqüência exposta em corte, verificou-se um padrão aproximado de "cogumelo" para a distribuição dos condutos de escape de fluidos e para pequenas dobras. Concluiu-se que, durante a sedimentação em provável ambiente de planície de marés, as interferências de ondas resultaram em um leito bastante complexo, ao qual foi adicionado ainda o escape de fluidos. Assim sendo, uma razão tectônica pós-sedimentação foi descartada como a principal responsável por tais feições.

Nos ritmitos desta unidade foram identificados, a exemplo da Bacia Eleutério, vários níveis fossilíferos. Em amostras previamente analisadas identificou-se microfósseis de Cloudina riemkeae e Titanotheca coimbrae. Em novas amostras recentemente coletadas para análises paleontológicas sistemáticas, poderão se obter, provavelmente, melhores subsídios. 
Figura 4.2.2 - Ritmitos de planície de marés ou de ambiente estuarino: pares sucessivos de siltitos argilosos cinza-escuro com arenitos muito finos cinza-claro, entremeados por arenitos mal selecionados marrom amarelados. Padrão de interferência de ondas e estruturas de escape de fluídos tornaram a estruturação final complexa. Topo para o alto da foto.

Figura 4.2.3 - Passagem dos ritmitos para arenitos médios a finos com estratificações plano-horizontais e cruzadas de baixo ângulo, com estrutura de corte-e-preenchimento na base destes envolvendo fragmentos de ritmitos. Topo para a direita da foto (SE).

Figura 4.2.4 - Metarenitos de granulação média a fina com estratificações cruzadas de baixo ângulo, prováveis estratificações cruzadas do tipo swaley (concavidade dos estratos para o topo, SE) e, talvez, hummockies (concavidade e convexidade para o topo). Nota-se a ocorrência de fluxos reversos, característicos da zona de espraiamento (swash-backswash). 

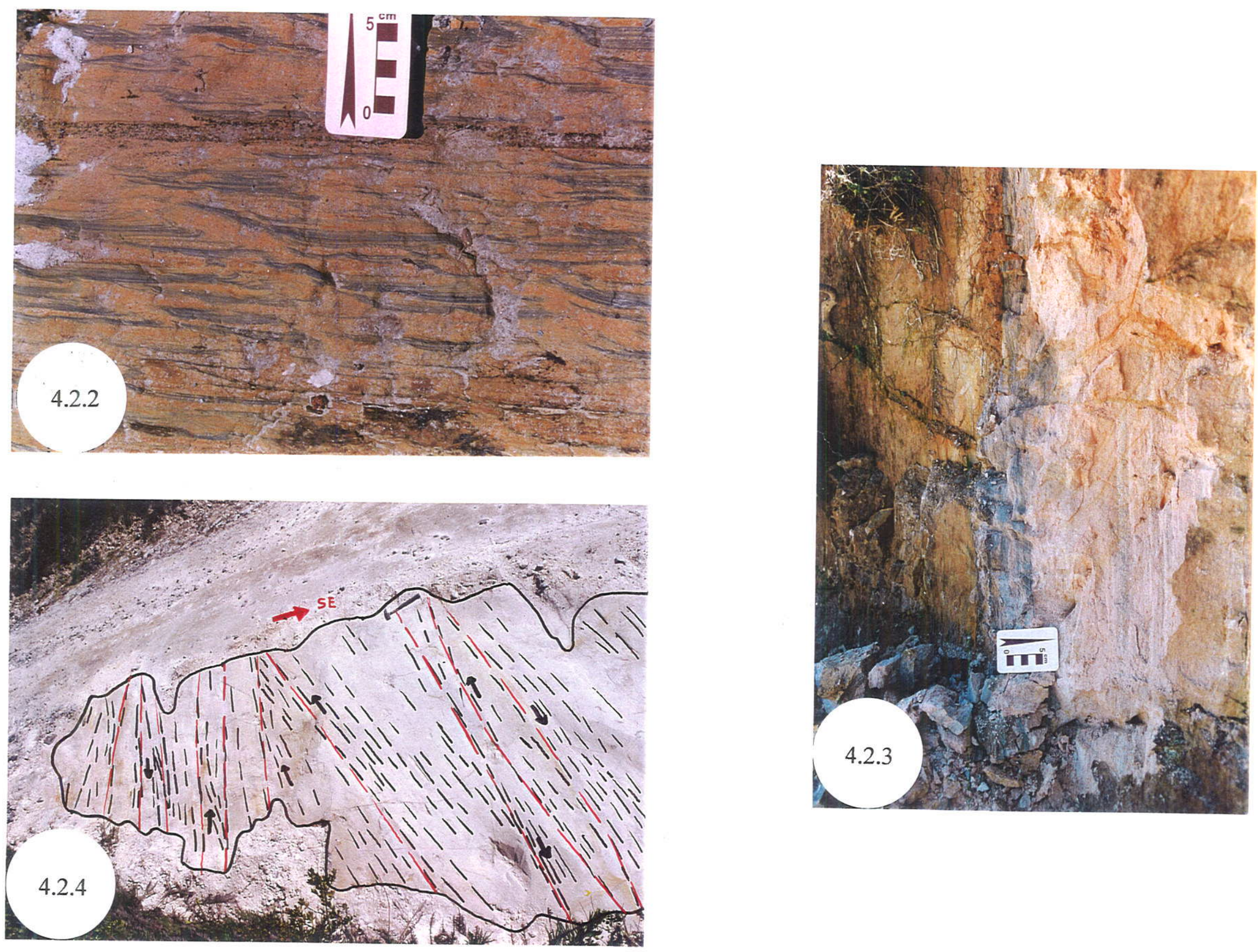
Esta unidade litoestratigráfica caracteriza-se por uma seqüência transgressiva (ritmitos de ambiente estuarino ou de planície de marés) com pulsos regressivos momentâneos (intercalações conglomeráticas), provavelmente relacionados aos intervalos entre tempestades ou a pulsações do nível do mar/subsidência da bacia, ou mesmo, a variações do aporte terrígeno continental.

4.2.2. Metarenitos feldspáticos e arcosianos com predomínio de estratificação cruzada de baixo ângulo.

Na porção central da bacia os metarenitos ultrapassam, em planta, a largura dos $1,2 \mathrm{~km}$ e daí, para nordeste e sudoeste, adelgaçam-se entre os metarritmitos com conglomerados e os metaconglomerados finos.

Os metarenitos feldspáticos a arcosianos repousam erosivamente (diastema) sobre os metarritmitos de planície de marés (Figura 4.2.3, ponto PI-03), estabelecendo uma sutil estrutura de corte e preenchimento com raros intraclastos de ritmitos "flutuantes" em areias médias a finas cinza-claro a bege esbranquiçado, quando alteradas, e com estratificação cruzada de baixo ângulo com lances decimétricos, desenvolvidos por cerca de $0,30 \mathrm{~m}$ de espessura. Após esta seqüência, em direção ao topo (SE), sucedem areias finas a médias, esbranquiçadas a bege, com estratificações cruzadas de baixo ângulo em lances métricos, marcadas pela laminação constante nos estratos dada pela alternância de termos médios e finos.

Entre um estrato e outro podem ocorrer intraclastos argilosos esbranquiçados, discóides achatados, com alguns centímetros de tamanho, que marcam os processos de reativação de fluxos. Intercalam-se freqüentemente outros estratos, também laminados e com níveis escuros de concentração de opacos, onde predominam areias grossas a médias sobre areias finas.

Localmente, esses estratos podem desenvolver, no topo, delgada seqüência com gradação normal, de areias médias ou grossas até areias finas siltosas a argilosas marrom a bege escuro. Gradações inversas, de areias finas a médias até grossas, não são raras. Notadamente, destaca-se por toda a área de exposição desta unidade a flagrante tabularidade das camadas, a continuidade lateral, a laminação interna dos estratos, a estratificação cruzada de baixo ângulo e os níveis de opacos associados às areias mais grossas. Localmente, "arqueamentos" suaves, côncavos e convexos para cima, dos estratos chegam a sugerir a presença de ondas de tempestades (hummockies) mas, as exposições descontínuas foram insuficientes para certificá-las (Figura 4.2.4). Entretanto, a presença de arqueamentos côncavos para cima, com base truncando os estratos inferiores com estratificações cruzadas de baixo ângulo, que no caso são muito 
freqüentes, seriam suficientes para se caracterizar a presença de estratificações cruzadas do tipo swaley (swaley cross stratification - SCS), estrutura sedimentar definida por Leckie \& Walker (1982). Segundo os autores tal estrutura ocorre acima do nível de base de ondas normais, atingindo até a região de espraiamento, e estaria associada a tempestades mais brandas, ou seja, não necessariamente associar-se-ia a um furacão. Quando presentes as estruturas do tipo hummockies, as estratificações swaley ocorreriam acima destas e, estas últimas, por sua vez poderiam estar sobrepostas pelos depósitos de praia (Leckie \& Walker 1982). Desse modo, as características acima listadas seriam suficientes para caracterizar um ambiente litorâneo, extensivo até a zona de espraiamento (swash zone), sob influência de ondas de tempestades, como, outrora, proposto por Riccomini (1993) e Riccomini \& Coimbra (1996).

Para o topo (SE), essas areias começam a ser intercaladas por areias conglomeráticas e conglomerados arenosos, até darem lugar aos metaconglomerados finos, da próxima unidade descrita a seguir, marcando tal passagem franca regressão marinha acompanhada da progradação de depósitos continentais.

\subsubsection{Metaconglomerados finos polimíticos}

Ocorrem como uma lente adelgaçada com direção NE-SW na porção média a ocidental da bacia, entre os metarenitos feldspáticos, que os limita a noroeste, e os metaconglomerados polimíticos grossos, a sudeste.

Caracterizam-se por estratos tabulares com espessuras decimétricas que, na base, apresentam conglomerados polimíticos com seixos e calhaus esparsos de granitóides, gnaisses, quartzitos, milonitos e xistos, às vezes com nítida imbricação dos clastos. Esses conglomerados são clasto-sustentados na base e gradacionam, para o topo, a conglomerados areia-sustentados e, finalmente, para arenitos mal selecionados. Estes arenitos, por sua vez, podem gradacionar a outros médios a finos e, não raro, até a arenitos finos siltosos. Não raro, também, podem ocorrer gradações inversas nos níveis de arenitos mal selecionados. Nas porções areia-sustentadas é comum o desenvolvimento de estratificações cruzadas planares (Figura 4.2.5) com clastos (seixos prolatos) em posição de repouso sobre as lâminas frontais (foresets). Ocasionalmente podem estar intercalados estratos decimétricos de arenitos mal selecionados, com estratificação plano-horizontal a cruzada de baixo ângulo, supostamente depositados por correntes marinhas litorâneas. 
Figura 4.2.5 - Metaconglomerados finos polimíticos com estratificação cruzada planar de pequeno porte, com clastos (seixos) de granitóides ao longo dos foresets, na altura da escala (com $8 \mathrm{~cm}$ de comprimento). Topo para a direita (SSE) e fluxo de baixo para o alto da foto.

Figura 4.2.6 - Metaconglomerado polimítico clasto-sustentado. Aspecto geral da rocha mostrando relações entre os clastos subarredondados, aparentemente com sutis imbricações na porção central (feição tectônica apenas?), e matacão de granitóide na porção direita inferior da foto. Notar foliação de cisalhamento predominantemente destrogiro, subvertical à foto, e que provoca deformações em planos preferenciais.

Figura 4.2.7 - Detalhe da matriz do metaconglomerado do Pico de Itapeva. A rocha encontra-se foliada, com grãos de quartzo conferindo textura granoblástica poligonizada, presença de clasto de feldspato potássico deformado (porção centroinferior da foto) e plaquetas de biotita verde acastanhada e agregados de sericita e quartzo muito fino marcando a foliação. 

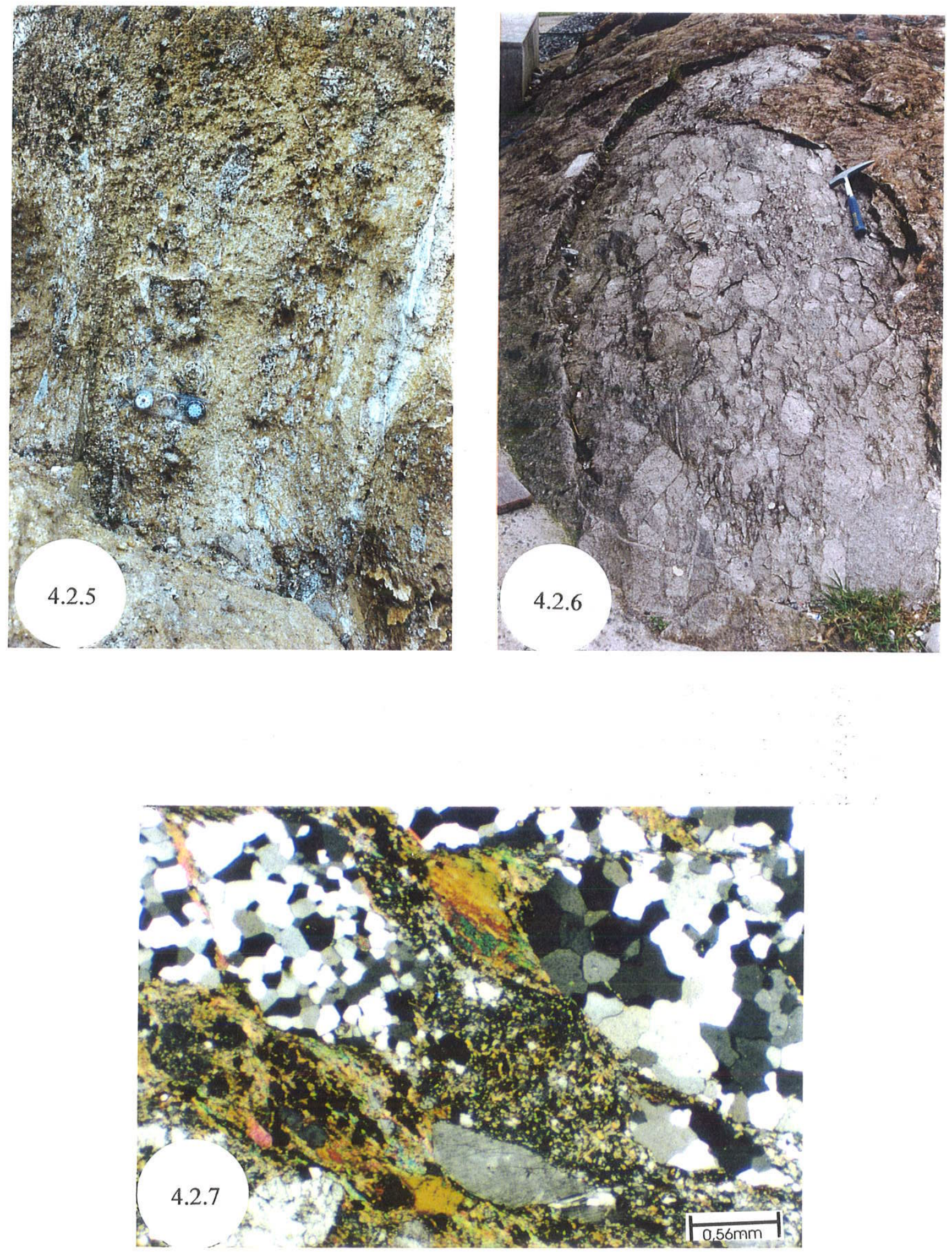
Para o topo transicionam para metaconglomerados polimíticos grossos, quando é marcado o predomínio de processos deposicionais subaéreos, em decorrência da continuada regressão marinha.

\subsubsection{Metaconglomerados grossos polimíticos}

Esta unidade ocupa toda a extensão da bacia remanescente, desde seu extremo SW ao extremo $\mathrm{NE}$, limitando-se tectonicamente a SE com o embasamento gnaissico atribuído ao Domínio Embu (Morais 1999), nos limites da escarpa do Planalto de Campos do Jordão ou em setores de sua transição para relevos inferiores.

Como já visto, esta unidade transiciona dos metaconglomerados finos conglomeráticos, de NW para SE, em direção ao topo da seqüência.

Em seu topo, a passagem para o embasamento ocorre através de imbricação tectônica, provocada pela reativação de ramificação de falha do Sistema Jundiuvira/Buquira. Como observado na região de São José dos Alpes, extremo NE da bacia, nessas passagens torna-se difícil discriminar, na maioria das exposições, os gnaisses do embasamento dos conglomerados, tendo-se em conta a brechação tectônica sobre ambos e as similaridades composicionais dos clastos conglomeráticos com o próprio embasamento. Tal dificuldade já havia sido relatada por Cavalcante et al. (1979) e Riccomini (1993).

Na região de São José dos Alpes, na descida para o reservatório da Represa Isabel, da Eletropaulo S/A, ocorrem várias intercalações (imbricações) de uns com outros, chegando atingir as "lascas" do embasamento espessuras de mais de $30 \mathrm{~m}$. Na escala utilizada para a representação cartográfica (Figura 4.2.1) tais "lascas" não foram discriminadas dos conglomerados.

Os metaconglomerados polimíticos apresentam-se em camadas de 0,5 a $1,0 \mathrm{~m}$ de espessura em média, conformando verdadeiros tapetes de tração (traction carpets) no sentido de Todd (1989). A base de cada camada é relativamente plana, o que confere tabularidade constante à seqüência. Caracterizam-se por conglomerados clasto-sustentados com blocos de até $1 \mathrm{~m}$ de tamanho, calhaus, seixos e grânulos de granitóides, gnaisses bandados, milonitos diversos, metabasitos, quartzitos, xistos aluminosos e feldspatos (Figura 4.2.6). A matriz arenosa lítica cinza-esverdeado ocupa apenas os interstícios interclásticos. É constituída também por feldspato, anfibólio, quartzo, biotita, muscovita, turmalina e opacos. A clorita, illita e sericita neoformadas 
desenvolvem-se principalmente nos interstícios intergranulares, em trilhas direcionadas pela dissolução por pressão. $O$ epídoto é comum e encontra-se amplamente disseminado ao longo de micro-fraturas, nas quais, às vezes, ocorre crescimento de calcita sintaxial. Em regiões de bordas mais tectonizadas observa-se o desenvolvimento de biotita neoformada, verde pardacenta (Figura 4.2.7). A imbricação de clastos é comumente observada, em que pese a deformação superposta. Gradações normais desenvolvem-se em espaços centimétricos a decimétricos, caracterizando para o topo metaconglomerados finos, seixosos, que podem ou não, gradar até areias mal selecionadas. Gradações inversas, também, podem ser mais raramente observadas em espaços decimétricos a centimétricos, quando são retomadas gradações normais.

Freqüentemente uma seqüência destas é recoberta erosivamente por areias grossas a médias com estratificação plano-paralela ou com ondulações plano-paralelas e, mais raramente, com estratificações cruzadas de pequeno porte ou cruzadas de baixo ângulo. A espessura dos recobrimentos arenosos atingem entre 0,2 a $0,4 \mathrm{~m}$, onde são interrompidas e sobrepostas por novo fluxo de tração. Localmente, no Mirante da Torre de TV, a estratificação cruzada desenvolveu-se sobre intercalações conglomeráticas mais finas (seixosas), ocupando os seixos os planos das lâminas frontais (foresets).

Nesta unidade, entre o Mirante da Torre de TV e as encostas da Torre da PM, mais a NE, estão expostas as melhores evidências de indicadores cinemáticos associados com o encurtamento e inversão da bacia, que apontam movimentação lateral direita (destrogira) durante esse evento. Tratam-se de seixos rotacionados com "rabichos" de sombra de pressão e de vazios em forma de "S" deixados por clastos intemperizados, principalmente de metabasitos, que foram condicionados a um binário destrogiro de esforços (Figura 4.2.8).

As intercalações arenosas que recobrem os tapetes de tração seriam, de acordo com Todd (1989), explicadas pelo "congelamento", com o fim das tensões dispersivas, do fluxo turbulento arenoso (aquoso) que acompanha, como uma cauda remontante, e sucede cada fluxo de alta densidade, logo quando este último se "congela", com o fim das tensões cisalhantes. Tais processos são comuns em ambientes de leques aluviais subaéreos ou em ambientes subaquosos de regiões de taludes. Neste último caso, outros processos coadjuvariam associados a outras fácies de águas profundas, o que não ocorre na Bacia do Pico do Itapeva.

A Figura 4.2.9 ilustra as relações entre os pacotes e, também, sugere uma interpretação dos processos atuantes durante a sedimentação, bem como dos ambientes deposicionais. Como pode ser visto, na base da seqüência reside o máximo transgressivo com depósitos relacionados a 
Figura 4.2.8 - Metaconglomerado clasto-sustentado com clasto de rocha metabásica intemperizado e com vazio (preenchido por fragmentos de rocha carreados em processos atuais) ressaltando estrutura em forma de " $\mathrm{S}$ ", compatível com deformação associada a binário destrogiro. (Ponto $01)$.

Figura 4.2.11 - Matriz do metaconglomerado clasto-sustentado apresentando deformação destrogira em grão de K-feldspato. O plano principal de cisalhamento orienta-se para $\mathrm{N} 50^{\circ} \mathrm{E}$ (corte em planta). Nota-se que o rompimento do grão ocorreu ao longo de fraturas antitéticas com deslocamento sinistrogiro. No fragmento central, observa-se que suas terminações exibem pequenas sombras de pressão onde ocorre a neoformação de filossilicatos e a recristalização do quartzo. (Nicóis cruzados)

Figura 4.2.12 - Em corte vertical da mesma amostra da figura anterior, com observador a NE, verifica-se que a movimentação horária conferida pelas feições deformacionais dos feldspatos, traduziria em uma componente inversa (o plano de cisalhamento mergulha para SE) para a deformação principal (destrogira). Nicóis cruzados + placa de gipso. 

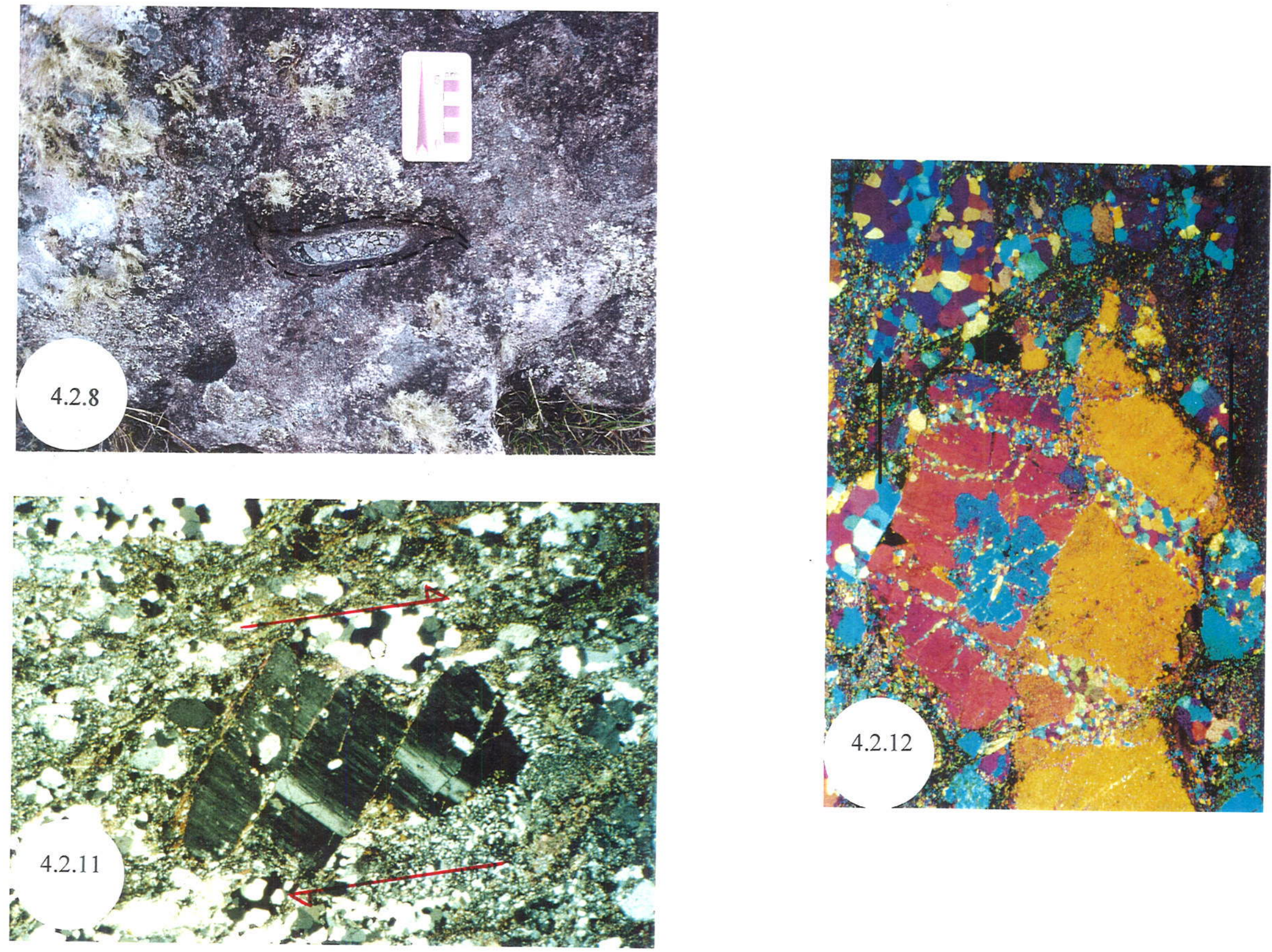


\section{COLUNA ESTRATIGRÁFICA DA BACIA DO PICO DE ITAPEVA}

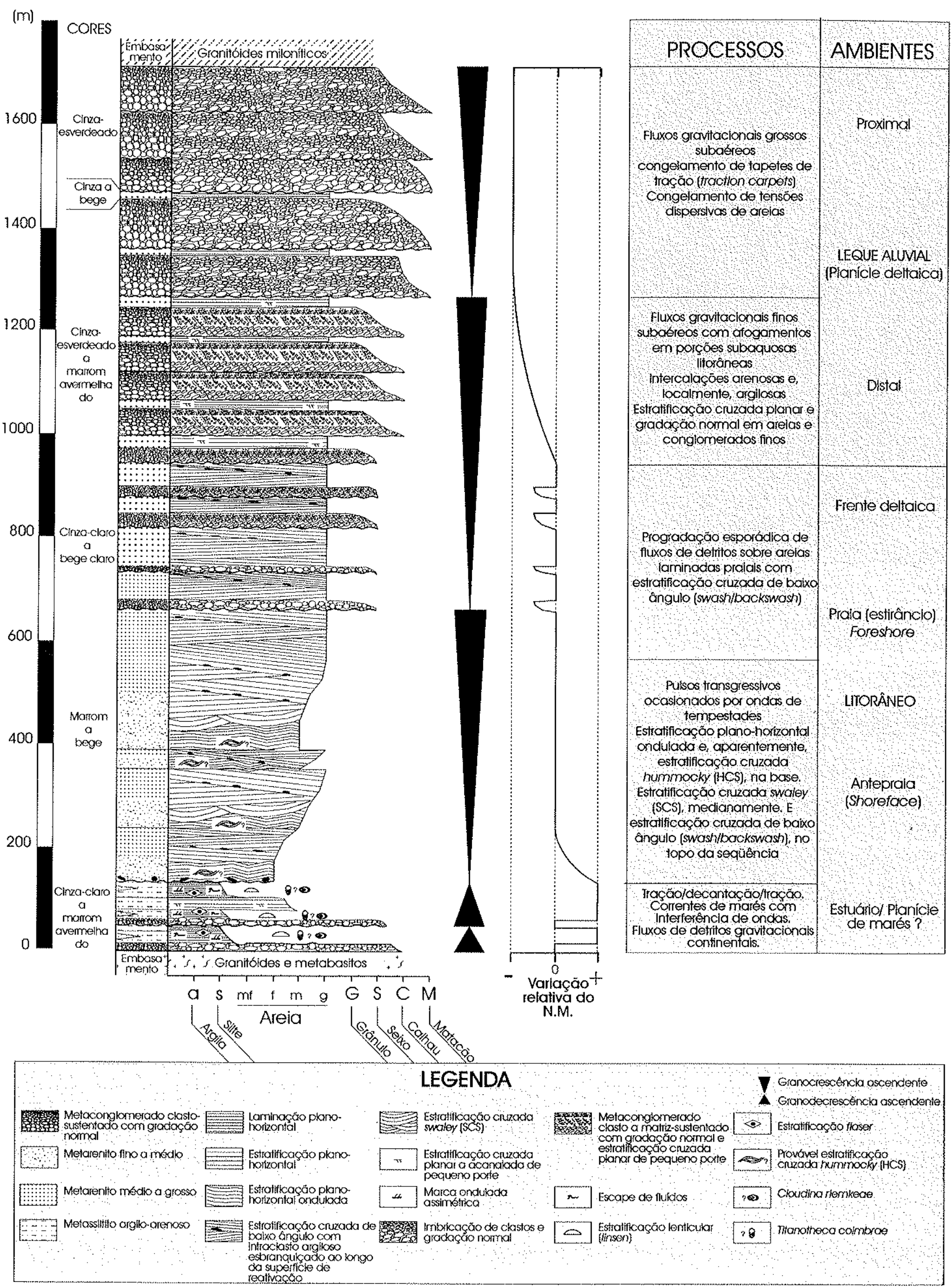

Figura 4.2 .9 - Coluna estratigráfica esquemática da Bacia do Pico de Itapeva 
ambientes estuarinos e/ou de planície de marés, interrompidos por termos conglomeráticos intercalados, os quais marcariam recuos relativos do nível do mar. Transicionalmente, entre a região de antepraia e a praia, inicia-se regressão marinha acompanhada por pulsos transgressivos, provavelmente ocasionados por tempestades esporádicas, até que se estabelecem as areias eminentemente de praia. O continuar da regressão é flagrante, com a progradação de termos conglomeráticos sobre os metarenitos praiais, a partir de sucessivas intercalações que, para o topo, darão lugar ao predomínio de metaconglomerados polimíticos finos, depositados nas porções distais da planície deltaica ou do leque aluvial progradante. E estes, finalmente, são sucedidos pelos metaconglomerados polimíticos grossos das porções proximais do sistema aluvial, quando é marcado o máximo regressivo.

Os depósitos, preservados, da Bacia do Pico de Itapeva, como se depreende do exposto, caracterizam regressão marinha predominante com o total entulhamento das águas marinhas rasas (litorâneas) por depósitos continentais de áreas-fonte próximas, o que poderia sugerir, a princípio, condições tectônicas e/ou variações climáticas enérgicas em sua evolução.

\subsubsection{Paleocorrentes}

Na Bacia do Pico de Itapeva as informações obtidas sobre o sentido das paleocorrentes foram escassas. As dificuldades encontradas para a caracterização destas estiveram associadas à precariedade das exposições rochosas, como a dimensão dos afloramentos e grau de alteração intempérica nos metapelitos, o predomínio de estratificações cruzadas de muito baixo ângulo nos metarenitos e, por último, as poucas evidências de imbricação de clastos nos metaconglomerados polimíticos, quase sempre obliteradas por planos de cisalhamentos associados aos processos de inversão e encurtamento da bacia.

Nos metarritmitos da base da bacia, situados no extremo NW desta, foram obtidas apenas 3 medidas absolutas no ponto 04 (Figura 4.2.1) que indicaram fluxos em ondulações cavalgantes de ENE para WSW e um outro de SE para NW, o que situaria o rumo do vetor médio próximo de W. No ponto 07 , ainda nesta mesma unidade, medidas aparentes (corte em planta) indicaram fluxos de E para W, também em ondulações cavalgantes. Em areias mal selecionadas a conglomeráticas intercaladas nos metapelitos (ponto 07) medidas absolutas de estratificações cruzadas de pequeno porte indicaram fluxos de NE para SW, sugerindo estar a NE as áreas-fonte continentais. 
Nos metaconglomerados finos obteve-se apenas uma medida absoluta no ponto 05 (estratificação cruzada de médio porte) indicativa de fluxo de NNE para SSW. No ponto 03, próximo já do ponto 01, medida aparente de paleocorrente (corte vertical, orientado segundo NNW-SSE) em estratificação cruzada de pequeno porte (Figura 4.2.5) indicou fluxo de SSW para NNE, concordante, portanto, com o da medida absoluta do ponto 05 .

$\mathrm{Na}$ unidade dos metarenitos as informações sobre o sentido dos fluxos também foram escassas. No ponto 03, quando os metarenitos se sobrepõem aos metarritmitos da planície de marés (Figura 4.2.4), os truncamentos de baixo ângulo entre os estratos indicam fluxos predominantemente para NW (corte em planta) e, subordinadamente, para SE. Em truncamentos de estruturações dômicas, provavelmente associadas a ondas de tempestades, os fluxos também rumam para NW. Considerando-se que a sedimentação ocorreu na região de espraiamento de ondas (swash-backswash) sob a influência esporádica de ondas de tempestades, infere-se que o continente estava situado a NW, sentido predominante dos truncamentos (swash).

Considerando-se a passagem gradativa dos metarenitos para os metaconglomerados finos e destes para os metaconglomerados polimíticos grossos, infere-se que os metaconglomerados progradaram sobre os metarenitos praiais, supridos por fluxos gravitacionais oriundos de áreasfonte situadas a N/NW.

\subsubsection{Análise Estrutural}

$\mathrm{O}$ acamamento reliquiar $\left(\mathrm{S}_{0}\right)$ dos depósitos da Bacia do Pico de Itapeva apresenta concordância estrutural com o trend da Zona de Cisalhamento de Jundiuvira, que intercepta o embasamento e é responsável pelo seu arranjo estrutural regional. O acamamento tem atitude média $\mathrm{N}^{\circ} 8^{\circ} \mathrm{E} 65^{\circ} \mathrm{SE}$ (Figura 4.2.10), apresentando quase nenhuma variação significativa de mergulhos para SE; apenas duas exceções ocorrem em zonas de extrema cataclase, na região de São José dos Alpes, extremo NE da bacia.

Contando com escassas medidas, a clivagem ardosiana $\left(S_{1}\right)$, que corta o acamamento, apresenta direção sub-paralela a este último, mas com mergulhos mais acentuados $\left(75-80^{\circ}\right)$ para sul. Esta relação seria indicativa de vergência para NW, entretanto, como ocorre na Bacia de Eleutério, inexistem dobramentos associados, cilíndricos ou cônicos, que possam caracterizar $\mathrm{S}_{1}$ como foliação plano-axial de dobras. É plausível associar sua gênese a um cisalhamento (rúptildúctil), imposto durante a fase de encurtamento e inversão da bacia, sob a égide de movimentação lateral direita da ZC de Jundiuvira. Como visto na Figura 4.2.7, a foliação $S_{1}$ está 
associada à neoformação de filossilicatos, como illita, sericita, clorita, epídoto e, destacadamente, a biotita verde acastanhada, que se desenvolveram em trilhas (micro-fraturas) direcionadas pela dissolução por pressão. Santoro (1998) associou a sua geração à conjugação das foliações "Sc" e "Ss" de Berthé et al. (1979), ocorrida durante a fase de dobramentos Dt (dobramentos tardios cambro-ordovicianos) que afetaram toda a região, inclusive os metassedimentos da Bacia do Pico de Itapeva, onde "Sc" constituíam planos de cisalhamentos com movimentação destrogira.

Santoro (1998) e Santoro \& Silva (1999) reportaram que as análises isotópicas K-Ar de biotita em granitóides da Suíte Serra Preta e de biotita xistos do Complexo Embu, na região de Campos de Jordão, assinalaram resfriamentos regionais ocorridos no Cambriano (530 Ma) e no Ordoviciano (497-470 Ma). A geração de $S_{1}$ provavelmente estaria associada à primeira etapa cambriana (530 Ma), marcando soerguimento regional (com inversão da bacia), o que concordaria com dados obtidos por Teixeira (1995) e Hama \& Cunha (1977), respectivamente, nas bacias de Eleutério e de Pouso Alegre.

Quanto ao elemento motriz, Riccomini (1993) já advogara uma movimentação lateral direita da zona de cisalhamento, o que se confirmou aqui também, seja nas observações de afloramentos (Figura 4.2.8) ou em seções delgadas (Figuras 4.2.12 e 4.2.13).

Após os eventos cambro-ordovicianos de resfriamentos regionais, ocorreram várias reativações na ZC de Jundiuvira, sob regimes deformacionais eminentemente rúpteis, que foram responsáveis pela proliferação e superposição de variadas populações de fraturas. Estas, não alteraram substancialmente as relações estratigráficas entre os pacotes da Bacia do Pico de Itapeva, senão, que os expuseram à erosão. Consequentemente, tais feições não receberam tratamento especial neste trabalho, a não ser para se delinear os limites entre os depósitos e entre estes e o embasamento. 


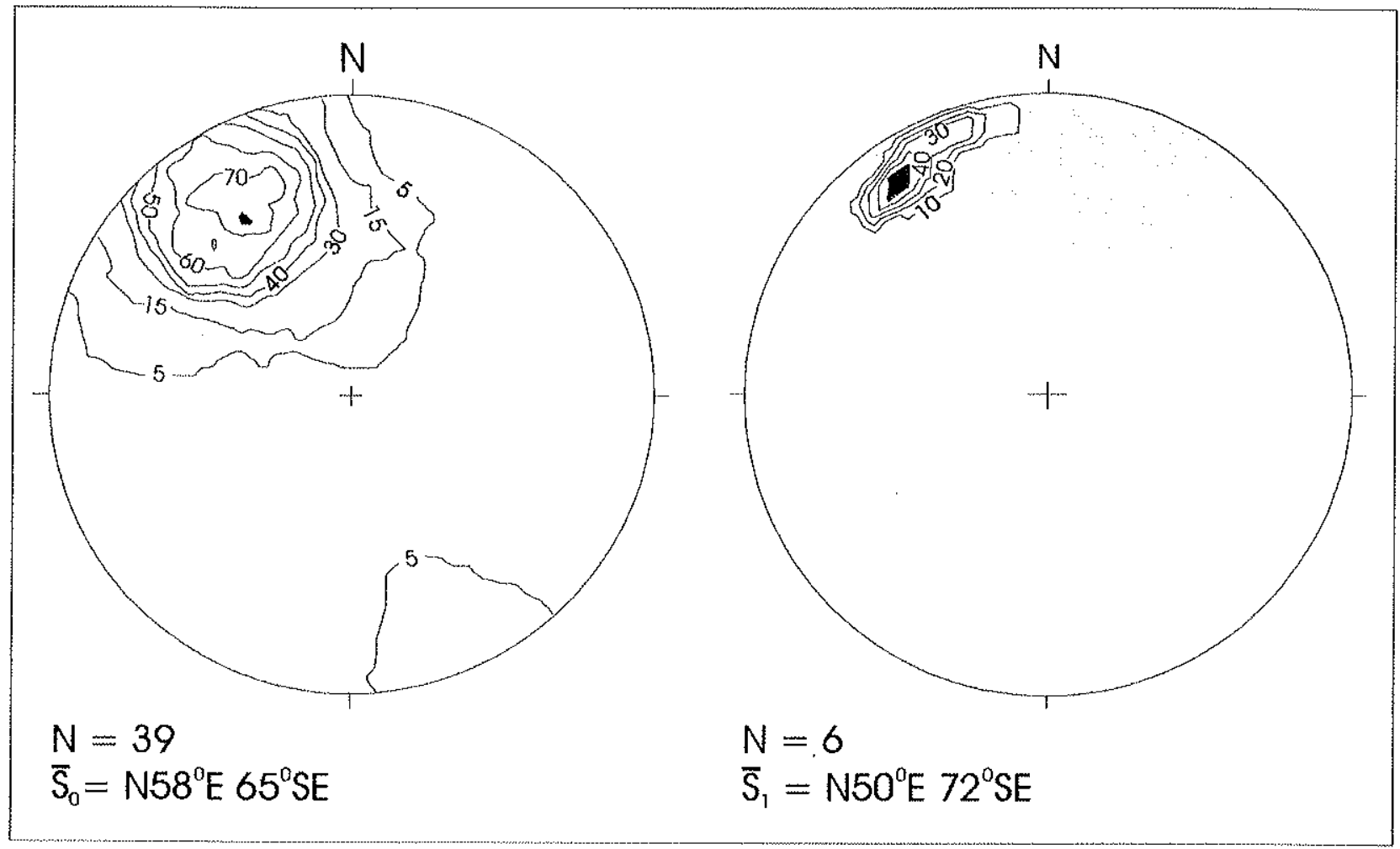

Figura 4.2.10 - Diagrama de igual área para medidas do acamamento reliquiar $\left(\mathrm{S}_{0}\right)$ e da foliaç̧̧ão metamórfica $\left(\mathrm{S}_{1}\right)$ da Bacia do Pico do Itapeva. $\overline{\mathrm{S}}_{0}$ e $\overline{\mathrm{S}}_{1}$ são, respectivamente, as atitudes médias do acamamento e da clivagem ardosiana. 


\subsection{Bacia de Pouso Alegre}

Os depósitos da Bacia de Pouso Alegre ocorrem a pouco mais de $3 \mathrm{~km}$ a noroeste da cidade de mesmo nome, sul de Minas Gerais, ocupando regiões de topo e encosta da Serra do Santo Antônio.

A bacia remanescente tem forma aproximadamente triangular isósceles (Figura 4.3.1) com a base, grosso modo, orientada segundo E-W. Os seus limites são dados por falhas que constituem ramificações da Zona de Cisalhamento de Monte Sião que corta, na região, embasamento atribuído ao Domínio da Faixa Alto Rio Grande (Campos Neto 1991 e Morais 1999).

Os depósitos apresentam estruturas sedimentares bem preservadas, com estratos sempre mergulhando para sudeste, com média de $30^{\circ}$, para onde também se dirige, invariavelmente, a polaridade estratigráfica. Foram distinguidas três unidades litoestratigráficas na bacia que, da base para o topo da seqüência (de NW para SE), são constituídas por: 1. Metaconglomerados polimíticos, 2. Metarenitos finos a siltitos calcíferos e 3. Metarenitos feldspáticos e arcoseanos com intercalações de metaconglomerados. Os depósitos perfazem, no total cerca de $1050 \mathrm{~m}$ de espessura. A seqüência conglomerática da base da bacia tem aproximadamente $280 \mathrm{~m}$ de espessura; os metarenitos finos e siltitos calcíferos que se sobrepõem a esta última atingem aproximadamente $120 \mathrm{~m}$ de espessura e, finalmente, os metarenitos com intercalações de metaconglomerados têm cerca de $480 \mathrm{~m}$ de espessura. $\mathrm{O}$ topo dessa seqüência é, em sua maior parte, encóberto por depósitos aluvionares recentes. Apenas no contato com o embasamento, nas porções finais do seu topo, no extremo sudeste da bacia, estão expostos cerca de $10 \mathrm{~m}$ de metaconglomerados polimíticos.

\subsubsection{Metaconglomerados polimíticos}

Ocupam a base da bacia, tendo seus limites dados por falhas que os separam do embasamento, direcionadas NE-SW e WNW-ESE, que se interceptam (Figura 4.3.1) formando o vértice superior do triângulo que limita a bacia.

No segmento NE-SW os contatos se dão, meridionalmente, com migmatitos e gnaisses do Complexo Amparo e, mais setentrionalmente, com gnaisses da Unidade Lambari, do Complexo 


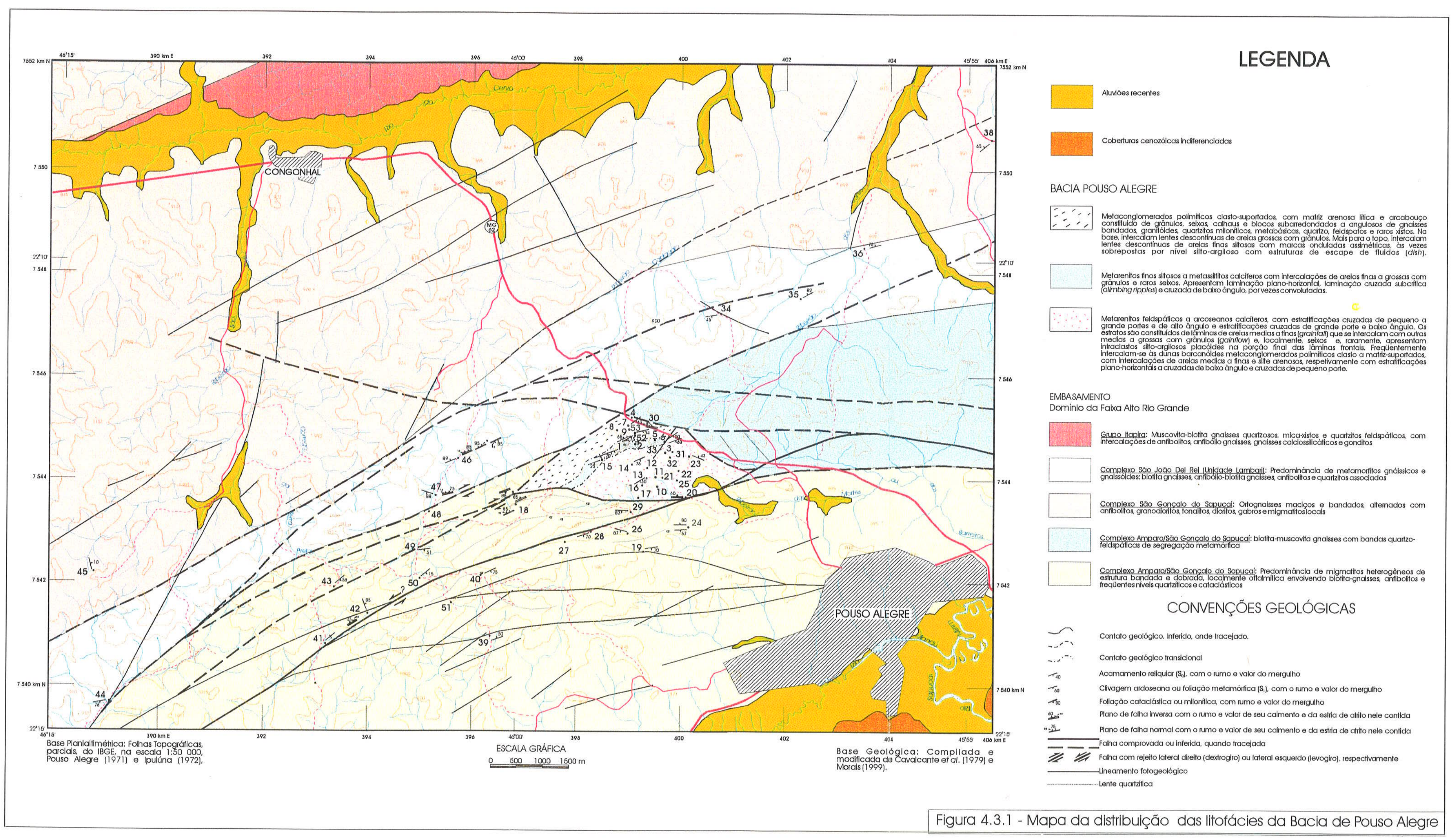


São João Del Rei (Cavalcante et al. 1979 e Morais 1999). No segmento WNW-ESE, os contatos ocorrem com rochas gnaissicas do Complexo Amparo/São Gonçalo do Sapucaí (Morais 1999).

Os metaconglomerados polimíticos são predominantemente clasto-sustentados. $\mathrm{O}$ arcabouço é constituído por clastos que variam de matacões a grânulos atingindo, os maiores, até $0,8 \mathrm{~m}$. Predominam calhaus e seixos sobre os demais clastos. Em geral, são arredondados a subarredondados, estando o grau de esfericidade inversamente dependente da anisotropia da rocha, ou seja, enquanto gnaisses bandados tendem a assumir formas mais retangulares, metabasitos e granitos porfiróides tendem a assumir formas mais esféricas (Figura 4.3.2). Os constituintes clásticos são de gnaisses bandados, ortognaisses e paragnaisses migmatizados e milonitizados, granitóides leuco e mesocráticos porfiríticos a porfiróides, muscovita xistos dobrados, quartzitos milonitizados, metabasitos (predominando quartzo anfibolitos), quartzo de veio, pegmatóides muscovíticos e turmaliníferos e feldspatos potássicos. A imbricação de clastos é comum na fração calhau, mas predomina a isorientação dos clastos maiores e oblatos ao longo do acamamento. A matriz arenosa lítica, feldspática a arcoseana, apenas ocupa os espaços interclásticos, tornando-se difícil, a olho nú, discriminá-la do arcabouço, graças à bimodalidade deste nas frações seixos finos e grânulos. A matriz é constituída de fragmentos líticos, feldspatos, biotita, turmalina, anfibólio, muscovita e opacos, além de minerais neoformados por dissolução por pressão intragranular, como illita, clorita e sericita, e em microfraturas o epídoto e, subordinadamente, a calcita. Como cimento pode ocorrer a calcita sintaxial.

Estes depósitos estão organizados em estratos tabulares (tapetes) com espessuras que variam de 1,0 a 0,4 m (Figura 4.3.3). Ocorre, da base para o topo, gradação normal quase sempre facilmente perceptível, marcada pela maior concentração de matacões na base, calhaus na porção média e seixos e grânulos na porção final. Podem suceder essa seqüência, transicional ou erosivamente, metarenitos mal selecionadas com estratificação/laminação plano-horizontal, cujas espessuras raramente ultrapassam os $0,2 \mathrm{~m}$, medindo quase sempre poucos centímetros de espessura e, geralmente, descontínuas. Tais descontinuidades devem-se às deformações de sobrecarga dos fluxos sucessivos ou mesmo à erosão provocada pelo corte e preenchimento. Essas características identificam-nos como fluxos densos subaéreos, associados a leques aluviais subaéreos.

A poucas dezenas de metros de seus limites noroeste, paulatinamente, iniciam-se intercalações de metarenitos e siltitos com argilitos que, a partir de espessuras de alguns centímetros na base chegam a superar 1 metro nas regiões de topo da seqüência, limites com os 
metassiltitos. Associam-se tais intercalações a ação de correntes marinhas litorâneas, provocadas por marés e ondas de tempestade.

Enquanto a imbricação dos clastos nos conglomerados polimíticos apontam transporte para WSW, nos metarenitos e metapelitos intercalados as estratificações cruzadas e ondulações assimétricas o indicam para NE, confirmando o encontro da cortina aluvial com corpo d'água marinho.

As intercalações arenosas, com espessuras de até $0,4 \mathrm{~m}$, são constituídas por arenitos mal selecionados na base e estão assentadas, predominantemente, sobre porções de metaconglomerados finos seixosos e, às vezes, assentam-se erosivamente sobre porções mais grossas. A transição, com gradação normal, para arenitos médios a finos ocorre de maneira brusca e estes gradacionam menos bruscamente para arenitos finos siltosos que, em geral, são recobertos por lâminas argilosas de alguns milímetros no topo, às vezes, interrompidas por deformações de sobrecarga e escape de fluidos (dish). Nova seqüência arenosa semelhante pode recorrer mas, em geral, sucede-lhes novo fluxo (tapete) de conglomerados. Os arenitos, às vezes, desenvolvem estratificações cruzadas de pequeno porte em sua base, mas predominam estratificações plano-horizontais suavemente onduladas $e$, às vezes, desarmonicamente onduladas pela sobrecarga.

As intercalações silto-argilo-arenosas podem variar suas espessuras de 0,3 a 1,0 m de espessura. Diferenciam-se em dois tipos: a) aquelas onde predominam ondulações pouco assimétricas a simétricas e com ondulações plano-paralelas e b) aquelas com ondulações planoparalelas ou cruzadas de baixo ângulo e com estratificação cruzada hummocky. No caso "a" os tipos de ondulações são dependentes do regime de fluxo. Observou-se, localmente, que da base para o topo as ondulações assimétricas, com transporte para ENE, passavam ao topo para aquelas simétricas, marcando aí uma maior calmaria no corpo d'água onde vigorava apenas ondas oscilatórias. Foram estas sucedidas, predominantemente, por ondulações plano-paralelas com poucas incidências de ondulações assimétricas ou cruzadas de baixo ângulo. Este nível parece corresponder a tempestitos distais, entretanto não foi possível caracterizar seguramente a tridimencionalidade da estrutura. As variações granulométricas são pouco perceptíveis em todos os níveis, a não ser na própria estrutura laminada dos estratos onde se alternam siltitos argilosos com siltitos arenosos.

No caso "b", a conjunção de ondulações côncavas e convexas com relação ao topo das camadas, gerando estratificações cruzadas de baixo ângulo, isolam leitos amendoados com 
Figura 4.3.2 - Detalhe dos metaconglomerados polimíticos clasto-sustentados, com destaque para as relações entre os clastos subarredondados a arredondados e com boa esfericidade de granitóides leucocráticos porfiríticos.

Figura 4.3.3 - Metaconglomerado polimítico clasto-sustentado organizado em tapetes de tração (traction carpets), com espessuras métrica a decimétrica, com definição de tapetes onde predomina granulometria de matacões e calhaus (na altura da escala) e tapetes com predomínio de granulometria calhaus e seixos, na porção central. Topo para a esquerda da foto (SE).

Figura 4.3.4 - Estrutura amendoada em metarenitos finos siltosos laminados, com 0,7 m de diâmetro, relacionada a ondas de tempestades (hummocky cross stratification), intercalados em metaconglomerados polimíticos das porções distais de leque aluvial, progradante sobre corpo aquoso marinho. 

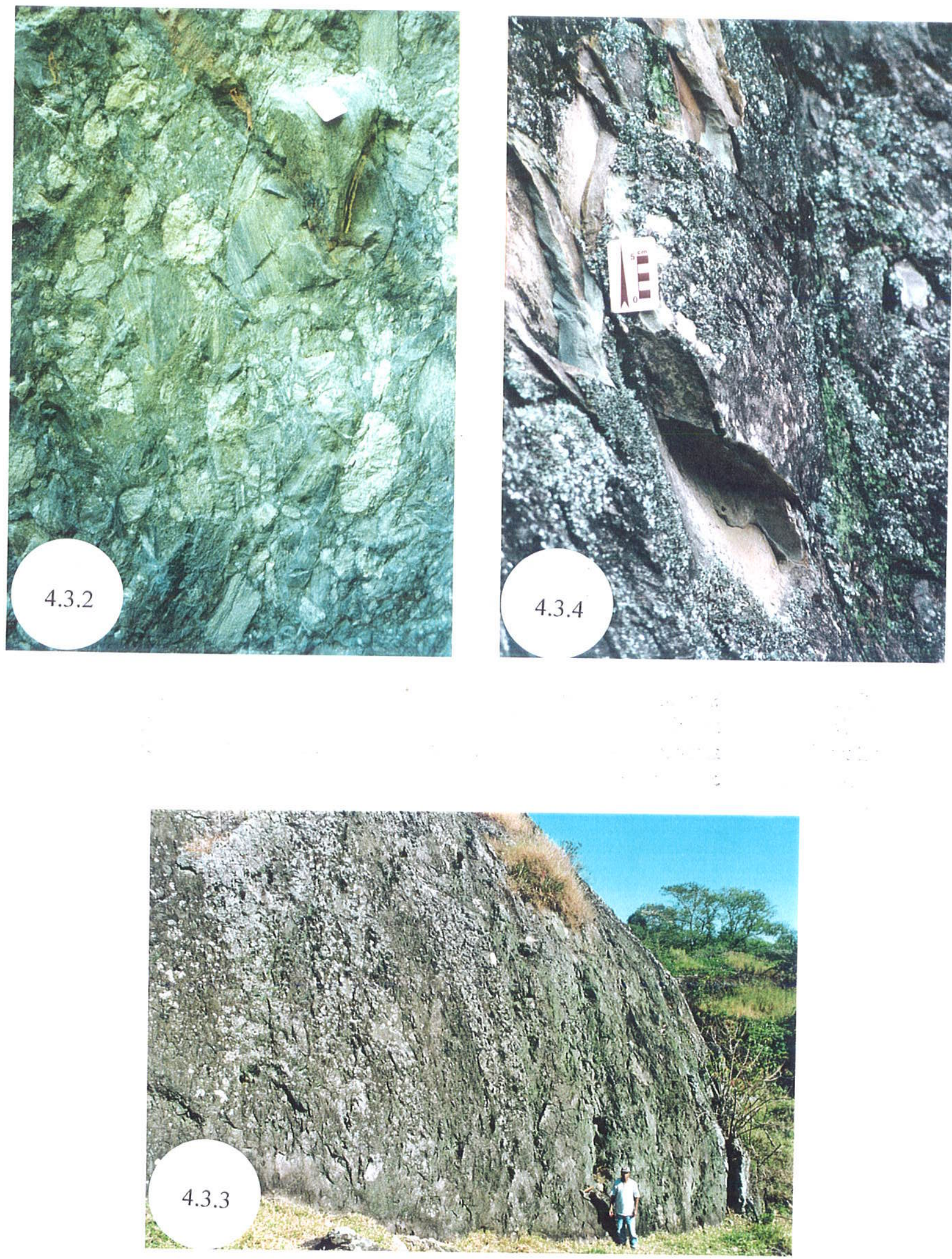
diâmetro de 0,7 m (Figura 4.3.4), caracterizando a participação de ondas de tempestades (HCS hummocky cross stratification), concomitante à progradação da franja aluvial no corpo aquoso.

Leonardos Júnior et al. (1971) descreveram que sobre os "paredões" do conglomerado (quase no topo desta unidade, próximo ao espigão da Serra de Santo Antônio) “(...) repousa uma sucessão de uma centena de leitos de conglomerados de grãos finos ou arenitos conglomeráticos passando gradualmente a siltitos e siltitos calcíferos" e que, “(...) lentes conglomeráticas repetem-se por cerca de $20 \mathrm{~m}$ e escasseiam da base para topo até passar definitivamente para a seqüência uniforme de siltitos e margas que ocorrem no topo da serra". Não foi possível verificar tais exposições contínuas, hoje cobertas por matas e pastagens, mas há neste trabalho a concordância com os autores citados de que a passagem da unidade dos conglomerados para os siltitos é gradacional, através de seqüência de fining e thickening-upward.

\subsubsection{Metarenitos finos e siltitos calcíferos}

Ocupam a porção do espigão da Serra do Santo Antônio, onde predomina vegetação densa de Mata Atlântica, ainda com remanescentes de floresta de araucárias. As exposições ocorrem neste espigão apenas ao longo da "picada do divisor," que separa as glebas do Sítio Monte Oreb, a noroeste, das glebas da antiga Fazenda Água Limpa, de propriedade do Sr. Creso Coutinho, a sudeste. Em perfis transversais ao divisor, ao longo da mata, somente pequenos blocos rolados foram encontrados, excetuando-se no ponto PA-15, onde afloram in situ. Apenas no extremo ENE desta unidade (pontos PA-05 e PA-06) é que são encontradas as melhores e maiores exposições dessas rochas, mas, ainda assim, descontínuas.

A base dessa seqüência inicia-se com siltitos cinza-claro finamente laminados planohorizontalmente, onde, em cada lâmina, gradação normal ocorre até argilitos cinza-escuro, conformando sucessão rítmica de lâminas claras e escuras intercaladas. As lâminas claras, siltosas, são mais espessas $(0,1 \mathrm{a} 1 \mathrm{~cm})$, enquanto as escuras são mais delgadas $(0,05 \mathrm{a} 0,4 \mathrm{~cm})$. É muito comum o desenvolvimento de ondulações de corrente de baixa energia ( $\lambda=2-5 \mathrm{~cm}$ e $\mathrm{A}=0,5-1,2 \mathrm{~cm})$ quando, ao longo das lâminas frontais pode ocorrer gradação normal de siltitos e argilitos, destacadas alternâncias rítmicas de cores claras e escuras. $\mathrm{O}$ transporte predominante é para NW. As espessuras dos estratos variam entre 1 a $4 \mathrm{~cm}$ em média. Estes são, freqüentemente, intercalados por arenitos mal selecionados e conglomeráticos (grânulos e seixos esparsos), também com nítida gradação normal, que podem variar a espessura de poucos milímetros até 5 cm. Localmente, a sucessão parace rítmica. Nos arenitos podem se desenvolver estratificações 
cruzadas de pequeno porte, geralmente secantes no topo e tangenciais na base, com transporte, onde observado (ponto 15) sempre dirigido para SW. A base é sempre erosiva sobre os estratos silto-argilosos e, seu topo, também, é sempre erodido por estes últimos, sugerindo não serem cogenéticos. Os estratos arenosos teriam aporte continental, enquanto os silto-argilosos teriam aporte marinho, mostrando que os fluxos mais distais dos leques aluviais atingiam as porções mais inferiores, próximas da base do nível de ondas, e neste sítio eram retrabalhados.

Localmente, nos níveis silto-argilosos, podem se desenvolver estratificações cruzadas de baixo ângulo $(\lambda=0,50 \mathrm{~m}$ e $A=0,04 \mathrm{~m})$ com laminação plano-paralela, sugestivas de tempestitos.

Para o topo da unidade, em suas porções médias, ocorre o predomínio de siltitos argilosos laminados, onde as incursões de areias mal selecionadas continentais são mais esparsas. É comum o desenvolvimento de ondulações cavalgantes (climbing ripple cross lamination) e de estratificação lenticular e flaser quando das incursões arenosas continentais. Localmente (ponto PA-05), ocorrem cristais idiomórficos de pirita que superam $1 \mathrm{~cm}$ de tamanho, sugerindo condições ambientais de baixa oxigenação.

À medida que se avança em direção ao topo da seqüência, desaparecem, praticamente, as incursões de detritos continentais passando a imperar a tríade: arenitos muito finos, siltitos e argilitos. Os arenitos são cinza-claro esbranquiçado que gradam ao topo para tonalidades cinzaclaro a médio (siltitos), quando são recobertos por fina lâmina de material cinza-escuro argiloso. Esta sequêencia atinge alguns centimétricos até poucos milímetros de espessura. Nos arenitos é freqüiente o desenvolvimento de ondulações assimétricas com lâminas frontais de alto ângulo $\left(>20^{\circ}\right.$ ) evidenciando baixas energias para os fluxos (Figura 4.3.5) com transporte para NW. Nas lâminas frontais a gradação normal até argilitos cinza-escuro é comum. Muito comum, também, são estratificações lenticulares (linsen) e, mais raras, do tipo flaser. Localmente, pequenas convoluções (stumps) podem ser observadas em níveis isolados. Também, localmente, desenvolvem-se níveis com espessuras decimétricas onde há o predomínio de arenitos muito finos laminados com estratificação cruzada de baixo ângulo, sugestivas de tempestitos. Deformações de sobrecarga são comuns no pacote, às vezes falseando ondulações. Neste caso, estruturas de escape de fluidos (dish) quase sempre se associam.

Nesse último nível (pontos PA-01, PA-02 e PA-06) foram identificados os microfósseis Soldadophycus major GAUCHER 2000 e Symplassosphaeridium sp. (Figuras 4.3.6 e 4.3.7), 
Figura 4.3.5 - Metarenitos muito finos, com estratificação cruzada de pequeno porte, gradacionais ao topo para metassiltitos cinza e metargilitos cinza-escuro. Até a altura da escala predominam metapelitos. Acima desta ocorrem metarenitos, cujas lâminas frontais dos estratos cruzados atingem mergulhos ao redor de $30^{\circ}$. Fluxo da esquerda para a direita da foto (NW).

Figura 4.3.6 - Soldadophycus major GAUCHER 2000. Colônia de esferulitos poligonizados pela compressão mútua, com desenvolvimento de indivíduos filamentosos cilíndricos, à esquerda da foto. Diâmetro médio dos esferóides $=9.5 \mu \mathrm{m}(7,5-12,5 \mu \mathrm{m}, \mathrm{N}=10)$. Amostra PA-06, metassiltito calcífero da Bacia de Pouso Alegre. Slide B $(54.2,105.2)$. Filme 25 (33). Fotografia cedida por Claudio Gaucher e Peter Sprechmann.

Figura 4.3.7 - Symplassosphaeridium $s p$. com colônia de esferóides poligonizados pela compressão mútua. Diâmetro médio dos esferóides de 9,8 $\mu \mathrm{m}(7,5-11,3 \mu \mathrm{m}, \mathrm{N}=8)$. Amostra PA-06, Metassiltito calcífero da Bacia de Pouso Alegre. Slide B (26.0, 94.8), filme 25 (32). Fotografia cedida por Claudio Gaucher e Peter Sprechmann. 

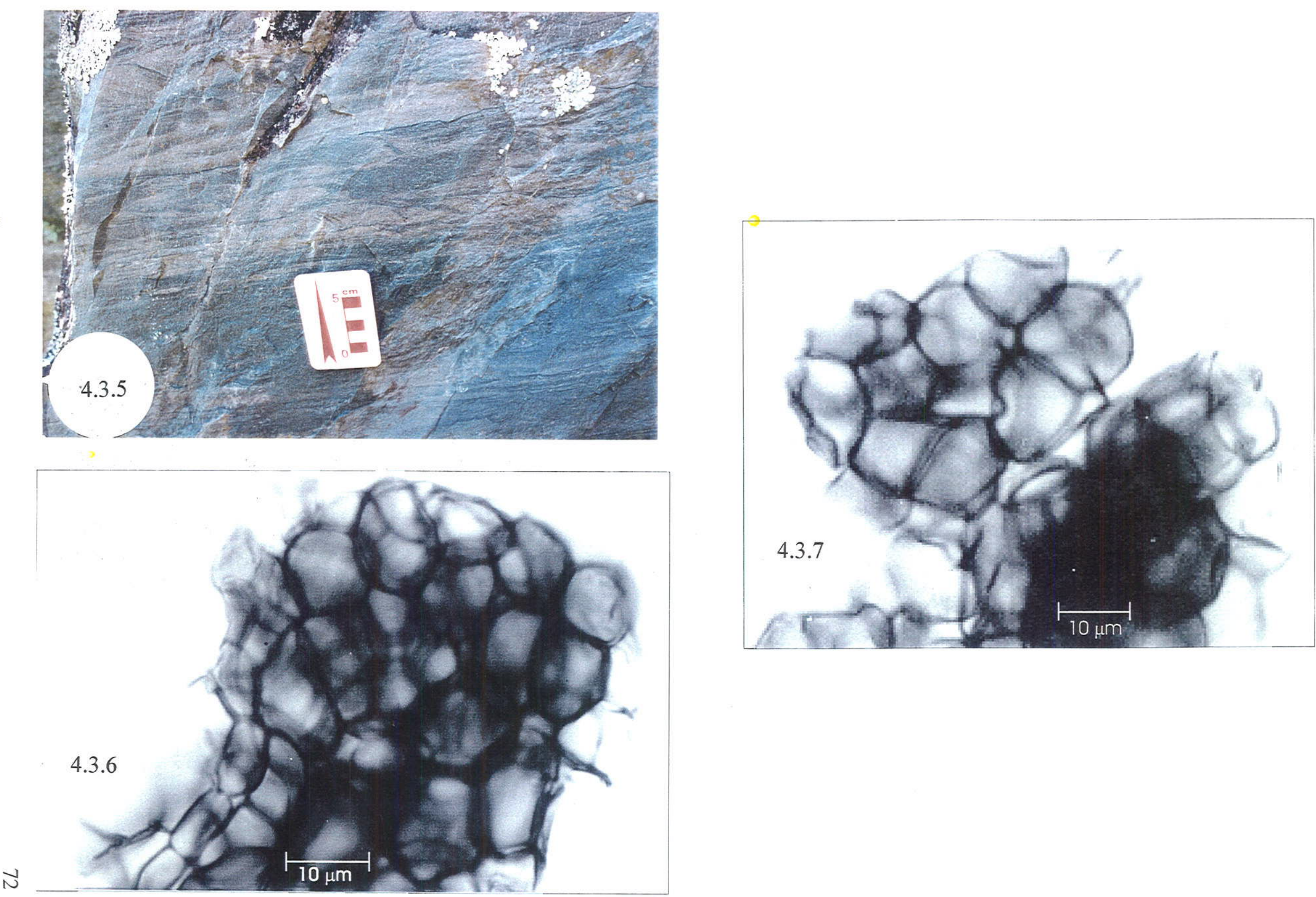
tratando-se de acritarcas já descritos, respectivamente, por Gaucher (2000) e Gaucher et al. (1999) no Grupo Arroyo del Soldado, no Uruguai, e pertencentes ao Vendiano Superior.

Novas amostras, que foram coletadas nesta unidade para análises paleontológicas sistemáticas, poderão, no futuro, enriquecer ainda mais o controle bio e cronoestratigráfico.

\subsubsection{Metarenitos feldspáticos e arcoseanos com intercalações de conglomerados}

As passagens dos metarenitos e siltitos calcíferos para os metarenitos com intercalações de conglomerados, apesar de transicional ocorre de forma brusca. Os ambientes foram se tornando paulatinamente mais rasos (regressão marinha) e os arenitos passaram a dominar sobre siltitos e argilitos, assim como os arenitos passaram a assumir granulometrias mais altas em estratos cruzados de grande porte. Concomitantemente a isso, recorreram níveis conglomeráticos que freqüentemente se intercalavam, até o final da sequiência.

A seqüência propriamente dita, inicia-se com arenitos feldspáticos a arcoseanos laminados, onde a seleção ocorre em lâminas alternadas $(1-0,3 \mathrm{~cm})$ de arenitos grossos a médios com arenitos médios a finos, em estratos cruzados de baixo ângulo e de grande porte (Figura 4.3.8), com lances que podem superar os $30 \mathrm{~m}$ (Figura 4.3.9). É muito comum o desenvolvimento de lentes ricas em opacos associando-se às lâminas de arenitos grossos a médios. Para o topo, refletindo o esmaecimento energético do fluxo, as estratificações assumem menor porte e passam a estratificações cruzadas planares e acanaladas, estas últimas de menor porte ainda. Neste nível predominam gradativamente arenitos finos, nos quais, em leitos tabulares, desenvolvem-se ondulações assimétricas $(\lambda=7 \mathrm{~cm}$ e $A=0,5 \mathrm{~cm})$ com cristas predominantemente retilíneas e, às vezes, com interferências de ondas que as tornam pseudosimétricas. Um novo fluxo com mesmas características e com espessuras ao redor dos $4 \mathrm{~m}$ pode sucedê-lo, erodindo em parte a seqüência de topo ou não, ao longo da superficie de reativação. Poderá, também, suceder um pacote arenoso ou um conjunto deles, fluxos conglomeráticos com base geralmente plana, localmente irregular, que literalmente os cinzela (Figura 4.3.10).

Os conglomerados são polimíticos e têm a mesma composição dos clastos daqueles conglomerados polimíticos da base da bacia, ressaltando, entretanto, o grande predomínio de clastos de milonitos (gnaisses e quartzitos milonitizados) sobre os demais, o que poderia sugerir reativação tectônica na área-fonte. Os clastos são subangulosos e de baixa esfericidade e apenas raramente apresentam-se subarredondados e com maior esfericidade, em se tratando de granitóides porfiróides isótropos. Matacões de até $1 \mathrm{~m}$ de tamanho podem ocorrer, mas o 
Figura 4.3.8 - Metarenitos médios a finos laminados com estratificação plano-horizontal a cruzada de baixo ângulo, associados a ambiente litorâneo de praia.

Figura 4.3.9 - Metarenitos médios a finos laminados com estratificação plano-horizontal e cruzadas de baixíssimo ângulo, com lances (comprimento de onda) superiores aos $30 \mathrm{~m}$.

Figura 4.3.10 - Metarenitos médios a finos, de dunas barcanóides, cinzelados por metaconglomerado polimítico clasto-sustentado, onde predominam clastos de milonitos.

Figura 4.3.11 - Metarenitos médios a finos laminados com estratificações cruzadas acanaladas de médio a grande portes, definindo dunas do tipo barcanóide. Fluxo da esquerda para a direita da foto. 

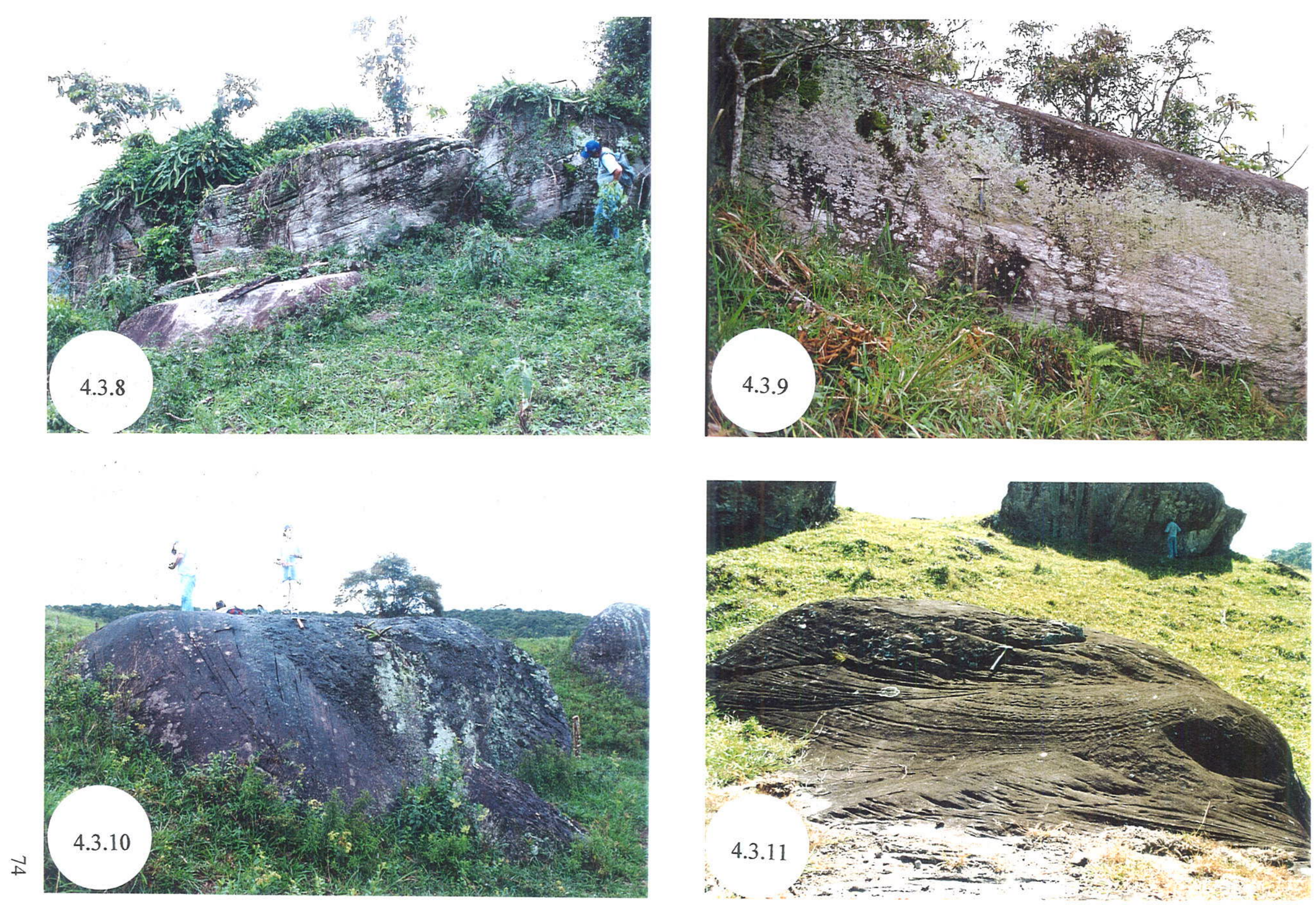
predomínio é de calhaus e seixos em arcabouço clasto-sustentado onde se destaca a bimodalidade com seixos finos e grânulos como pseudo- matriz. A matriz propriamente dita é lítica, arcoseana em geral, e apenas ocupa interstícios entre os clastos. Gradações normais, e não muito raro inversas, são constantes e ocorrem em intervalos de poucos decímetros a centímetros dando passagens a conglomerados seixosos, arenitos conglomeráticos e, finalmente, a arenitos mal selecionados e finos a médios com estratificações cruzadas de baixo ângulo e cruzadas de pequeno a médio porte, que se desenvolvem em estrato decimétrico. Às vezes, também, arenitos mal selecionados com estratificação plano-horizontal dispõem-se sobre o topo da seqüência descrita, ou até sobre a sua porção mediana, de modo erosivo como se prenunciassem a chegada de novo fluxo conglomerático, para os quais transicionam com gradação inversa. Outras vezes, ocorrem isoladas com base e topo erosivos entre 2 fluxos de conglomerados.

À medida que se avança para SE nas porções de meia encosta e final da encosta do flanco sul da Serra do Santo Antônio, mais para o topo da bacia, ganham predomínio os arenitos com estratificação cruzada acanalada de grande porte (dunas barcanóides, Figura 4.3.11) ao lado daquelas cruzadas planares e cruzadas acanaladas de pequeno porte. Da base para o topo, a seqüência de ocorrência de uma sobre as outras é a seguinte: estratificação cruzada planar, cruzada acanalada de grande porte e, finalmente, acanalada de pequeno porte. Em seqüências incompletas, sem estratificações cruzadas planares, na base podem ocorrer cruzadas acanaladas de pequeno porte sucedida por aquelas de grande porte. As estratificações cruzadas acanaladas podem ser, à primeira vista, confundidas com aquelas de deserto (dunas barcanas), mas diferem destas quanto à má seleção e arredondamento dos grãos de areia e à ocorrência de clastos (seixos) erráticos entre as lâminas e de grânulos (quartzo e feldspató) nas lâminas mal selecionadas. As características das lâminas são em muito semelhantes às descritas nas porções de base: alternância de lâminas de arenitos médios a finos com outras de arenitos mal selecionados com grânulos. A gradação normal ocorre nas primeiras e a gradação inversa ocorre nas lâminas mal selecionadas, provavelmente devido aos processos de fluxo de grãos (grain flow) nas lâminas frontais das dunas.

A presença de conglomerados polimíticos interceptando e se intercalando nessa seqüência é uma constante. Composicionalmente são semelhantes aos anteriores da seqüuência de base, onde predominam clastos miloníticos. Diferem daqueles, também, quanto à maior participação de arenitos intercalados e quanto ao predomínio da granulometria calhaus e seixos nos clastos. Ás vezes, também, os conglomerados podem ser apenas seixosos e cortados por arenitos mal selecionados com estratificação plano-horizontal a cruzada de baixo ângulo. 
Localmente, ocorre matacão com mais de $1 \mathrm{~m}$ de tamanho, como errático, no topo de conglomerado com calhaus que é sucedido por outros seixosos com gradação inversa até outros com calhaus (Figura 4.3.12).

As paleocorrentes indicam fluxos nas dunas barcanóides (com estratificação cruzada acanalada) no rumo NNE, quase que invariavelmente. Nos arenitos mal selecionados ou não, e associados com os fluxos conglomeráticos intercalados, o transporte é para SE.

Nas dunas barcanóides, é comum na região de sua base (bottom) das lâminas frontais (foresets) a ocorrência de intraclastos com $5-8 \mathrm{~cm}$ de tamanho lenticulares alongados, argilosos e esbranquiçados, que se alinham entre as lâminas. Muito comum também é a ocorrência de pseudo estruturas concrecionárias, que na verdade constituem-se em vazios deixados pela alteração e remoção de material (arenito fino siltoso) que compunham marcas onduladas assimétricas ao longo dos foresets, em planos de superficies de reativação (Figura 4.3.13). Em geral essas marcas onduladas têm cristas retilíneas e a assimetria aponta fluxos para norte. A Figura 4.3.14 ilustra molde (base da onda) assimétrica $(\lambda=10 \mathrm{~cm}$ e $A=0,5)$ indicando fluxo em cristas retilíneas para $\mathrm{N}$.

Localmente (ponto PA-17), intercalação de arenitos finos com clastos (seixos e calhaus) e tênue estratificação plano-horizontal, apresenta lâminas argilosas esbranquiçadas com estruturas de escape de fluidos. Deste ponto em direção à sudeste as exposições rochosas foram encobertas pelos depósitos aluviais recentes de várzea e só reaparecem no início de encosta, além da várzea, na margem direita do Ribeirão das Mortes ou dos Barreiros (ponto PA-20). Neste ponto tem-se o contato bacia/embasamento. Os depósitos da bacia, muitíssimo alterados, são conglomerados polimíticos marrom amarelados com seixos e calhaus de granitóides, quartzitos e milonitos, que se expõem por cerca de $8 \mathrm{~m}$ no leito de estrada vicinal não pavimentada.

Apresentam-se pouco deformados, quando são interceptados por falha com direção $\mathrm{N} 90^{\circ} \mathrm{E} 60^{\circ} \mathrm{N}$ que os coloca em contato com granitóides muito alterados, aparentemente leucocráticos, bastante brechados e milomitizados. Nesta altura de borda da bacia já não se verifica a presença dos metarenitos, mas apenas dos metaconglomerados.

A primeira seqüência, mais de base, é típica de depósitos de praia caracterizando a zona de estirâncio (swash e backswash). A seqüência com dunas barcanóides caracterizaria zona de ante-praia acima do nível de base das ondas, sujeita às correntes litorâneas que se dirigiam para o continente. 
Figura 4.3.12 - Metaconglomerado polimítico com bloco de até $1 \mathrm{~m}$ de gnaisse bandado milonítico e outros da mesma rocha na granulometria calhaus e seixos. Nota-se gradação inversa no pacote até o topo do matacão, quando sucede outro fluxo de conglomerado fino.

Figura 4.3.13 - Truncamento com ângulo aparente de $45^{\circ}$ entre estratos de duna barcanóide. No estrato superior aparecem, ao longo das lâminas frontais, sucessivos níveis com vazios deixados pela alteração intempérica de material areno-siltoso, constituinte de marcas onduladas assimétricas. O fluxo é da esquerda para a direita da foto. A escala tem $7 \mathrm{~cm}$ de diâmetro.

Figura 4.3.14 - Base de estrato de duna barcanóide, em bloco rolado e com topo invertido, com moldes de marcas onduladas assimétricas com cristas retilíneas e com pseudo fluxo da esquerda (alto) para direita (baixo). No canto inferior esquerdo da foto, podem ser vistas intercalações lenticulares de opacos entre arenitos médios a grossos laminados.

Figura 4.3.18 - Metaconglomerados polimíticos com intercalações de metarenitos e siltitos avermelhados cortados por planos escalonados de cisalhamento rúptil-dúctil com mergulhos para NW, onde se coloca o observador. As setas vermelhas indicam o sentido de movimento da capa e as pretas, da lapa. Nota-se pequenos drags nos termos siltosos, que indicam componente inversa para a movimentação. A ausência de estriamentos nos planos de falha não permitiu caracterizar a componente horizontal. (Ponto 52). 

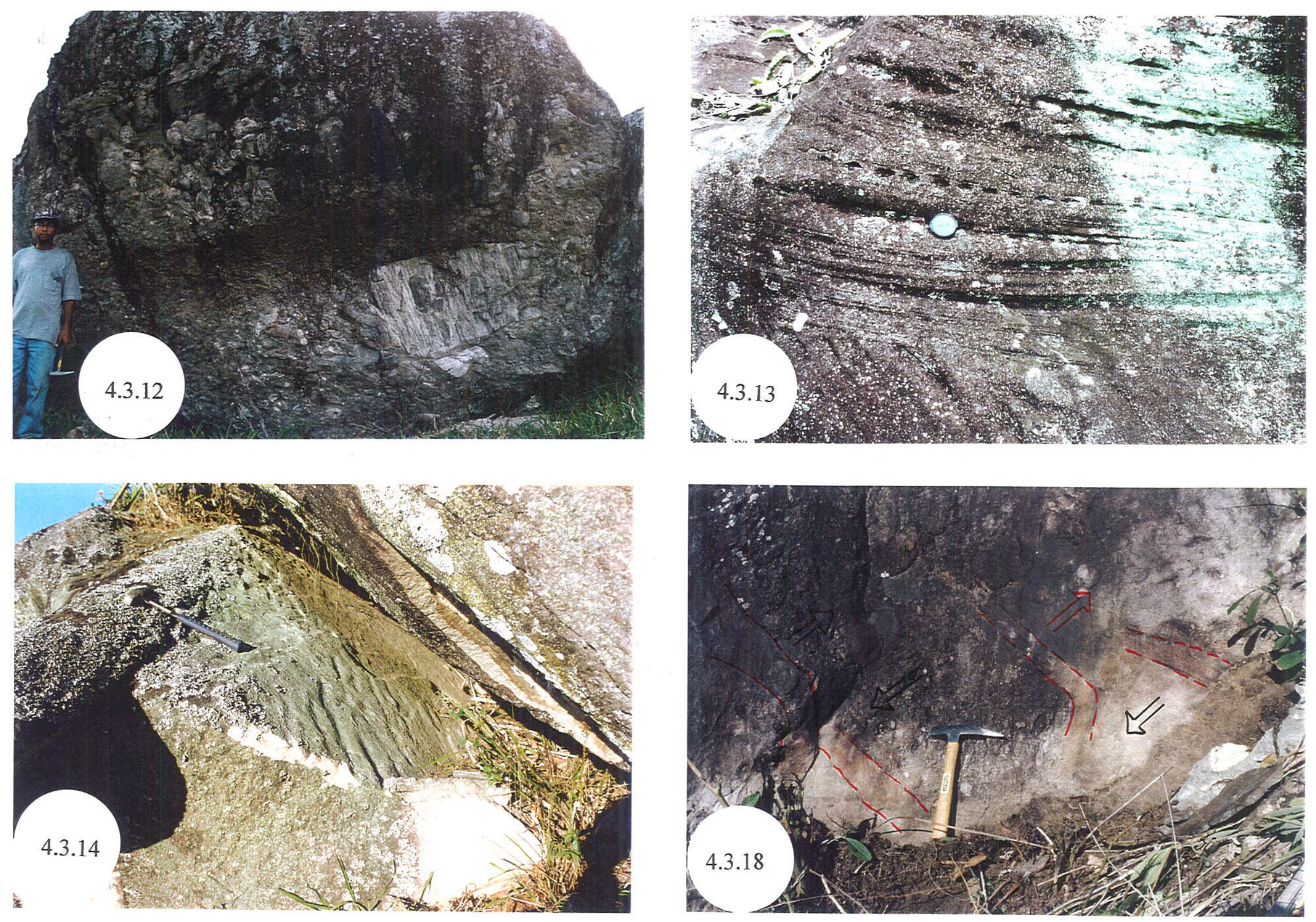
A Figura 4.3.15 sintetiza o pacote deposicional da Bacia de Pouso Alegre, as relações entre as sequiências sedimentares, os processos e ambientes deposicionais envolvidos durante o preenchimento da bacia. Como pode ser visto, a seqüência inicial da base, de metaconglomerados polimíticos, é representativa de regressão marinha, quando, paulatinamente, inicia-se fase transgressiva marinha com o afogamento das porções mais distais do leque aluvial (frente deltaica) em corpo d'água litorâneo raso. O máximo transgressivo é atingido com depósitos finos da região de antepraia (shoreface) ou até transicional para plataforma rasa (offshore), em condições de águas oxigenadas a pouco oxigenadas (cristais de pirita do ponto PA-05). Pequena regressão marinha instala-se com a deposição de extenso pacote de sedimentos praiais (metarenitos) intercalados por outros de proveniência continental, representados por metaconglomerados polimíticos ricos em clastos de rochas miloníticas. De modo gradual, talvez, a seqüência anterior dá lugar a outra representativa de águas pouco mais profundas, das regiões de antepraia, onde a ação de ondas normais e de correntes de marés construiu espetaculares megamarcas onduladas com fluxos voltados para o continente. Ainda assim, neste ambiente as intercalações conglomeráticas mostraram-se constantes. Ao final da seqüência, aparentemente retornariam condições transgressivas, entretanto a ausência de exposições rochosas não permitiu confirmá-lo. Após esse intervalo sem exposições, no topo da bacia (contato com o embasamento) expõem-se metaconglomerados polimíticos, que poderiam constituir-se em mais uma das intercalações ou representar estágio regressivo.

\subsubsection{Paleocorrentes}

$\mathrm{Na}$ Bacia de Pouso Alegre, os termos psefiticos e pelíticos apresentaram maiores dificuldades de caracterização do sentido das paleocorrentes. Na unidade dos metarenitos as estratificações cruzadas de dunas barcanóides ofereceram, por sua vez, ótimas referências, entretanto a maioria das exposições encontram-se em blocos rolados. Quando nesses blocos, o acamamento reliquiar $\left(S_{0}\right)$ e a clivagem ardosiana $\left(S_{1}\right)$ estiveram disponibilizados, foi possível recuperar, a partir da comparação com outras exposições in situ, a posição original do bloco e, consequentemente, obter o sentido das paleocorrentes.

Nos metaconglomerados polimíticos (Figura 4.3.16), apenas em dois locais (pontos $07 \mathrm{e}$ 53) obteve-se o sentido aparente (relativo ao plano de corte; no caso, em planta) a partir da imbricação de clastos, que forneceram sentido dos fluxos de NE para SW. Nesta unidade (ponto 53), intercalação metapelítica com ondulações cavalgantes associadas a correntes de marés (e talvez a ondas de tempestades) indicaram fluxos no sentido inverso, de SW para NE. 


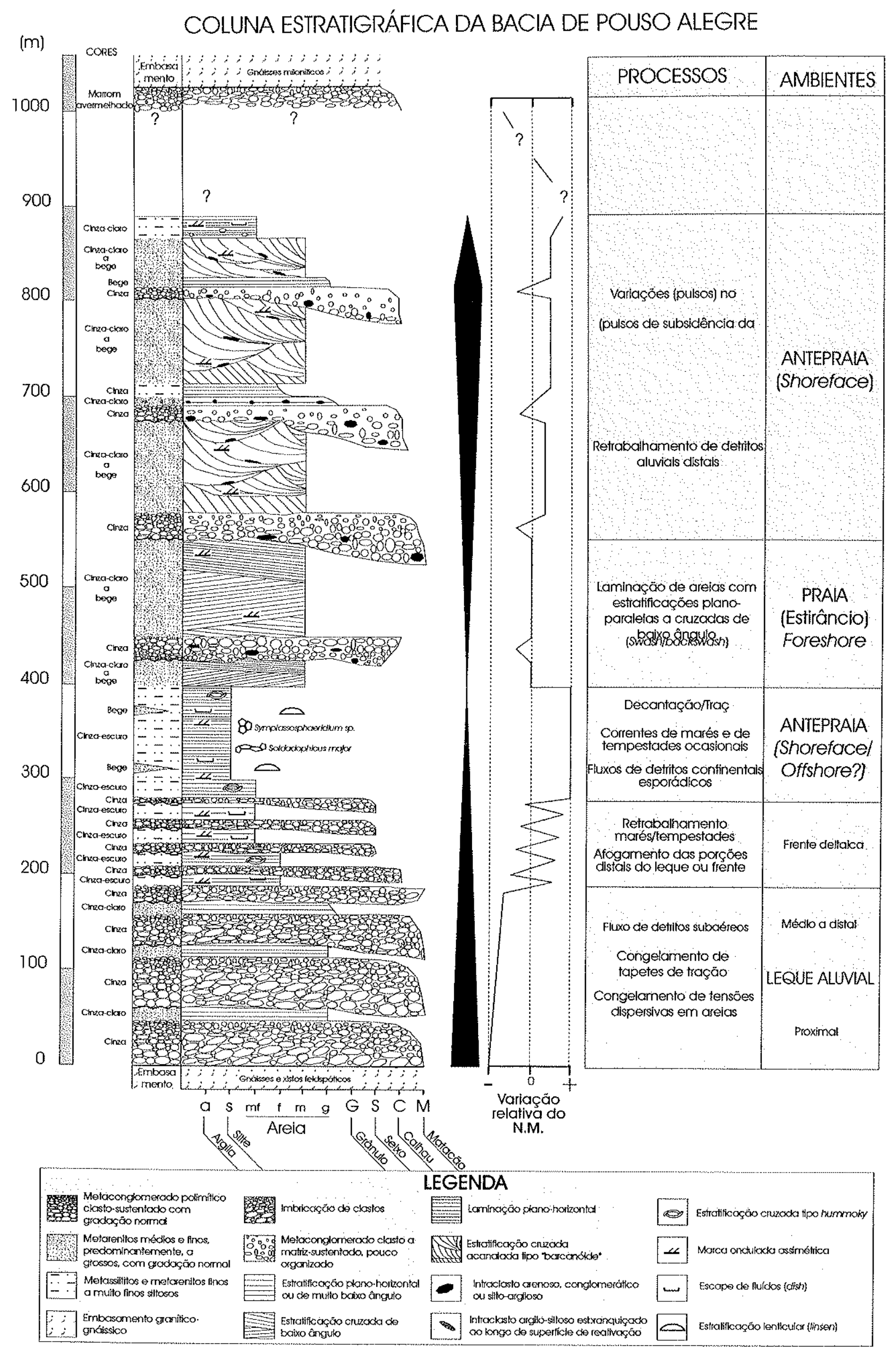

Figura 4.3.15 - Coluna estratigráfica esquemática da Bacia de Pouso Alegre 


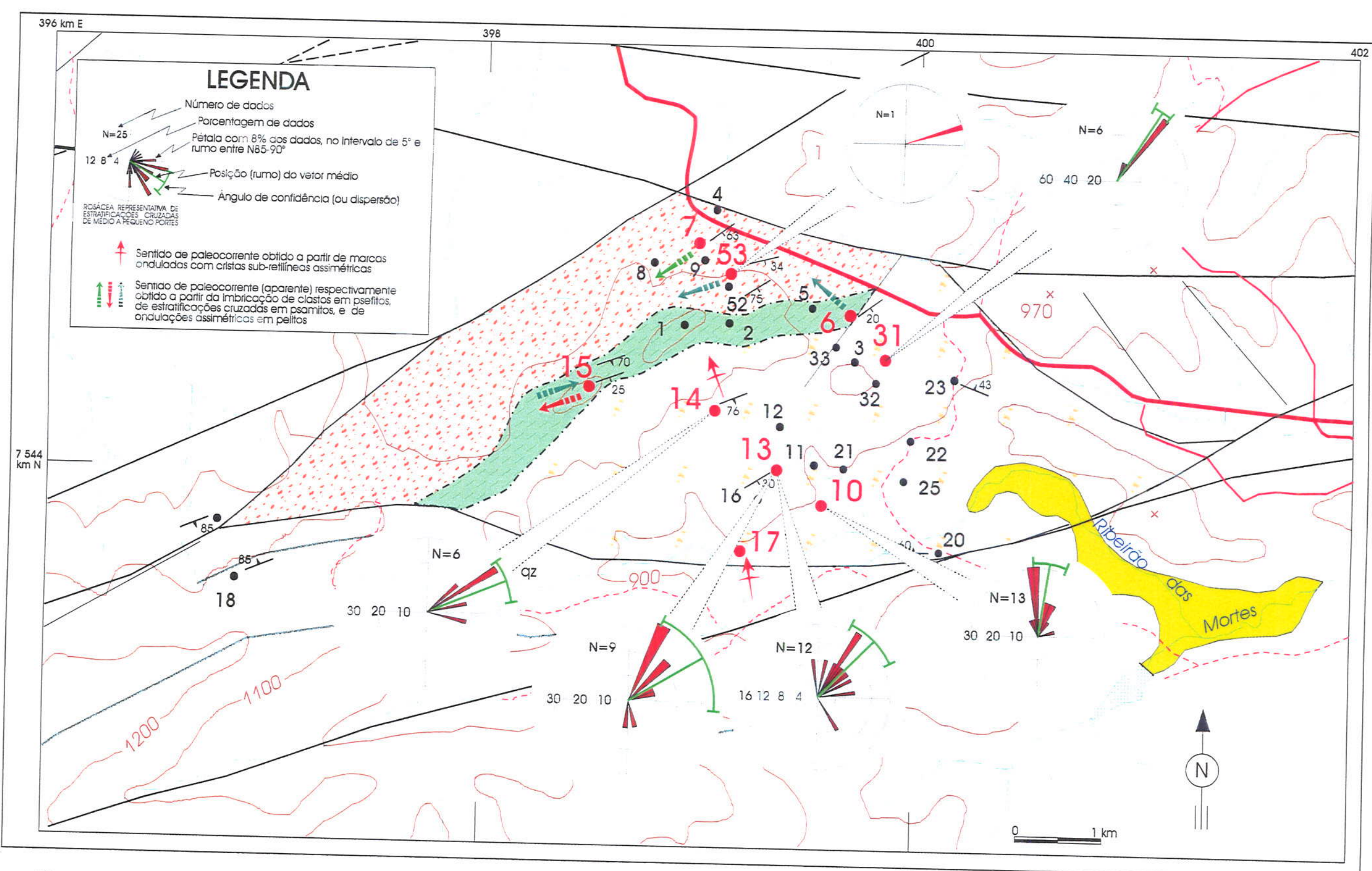

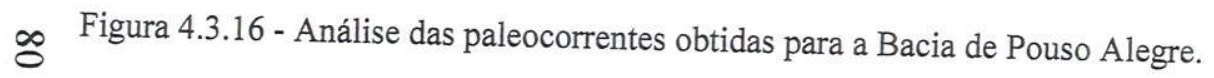


Nos metassiltitos calcíferos, apenas dois locais (pontos 06 e 15) forneceram medidas de paleocorrentes, também aparentes. No ponto 15, as ondulações cavalgantes e de ondas de tempestades (micro-hummockies) mostraram sentido de fluxos de SW para NE, enquanto intercalações de arenitos mal selecionados a conglomeráticos mostraram sentido de fluxos inversos (de NE para SW) em estratificações cruzadas de pequeno porte. No ponto 06 (Figura 4.3.5) ondulações cavalgantes sub-críticas em siltitos argilosos e arenosos mostraram fluxos dirigidos de SE para NW, em corte vertical orientado segundo NW-SE.

Já nos metarenitos com intercalações conglomeráticas, onde predominam dunas barcanóides, os fluxos predominantes têm sentido de SW para NE, quase que invariavelmente (Figura 4.3.16). Nos pontos 14 e 17 desta unidade, marcas onduladas assimétricas com cristas retilíneas a sub-retilíneas, as quais recobrem as porções de topo das dunas barcanóides, indicaram fluxos no sentido de SSE para NNW, mostrando pequeno desvio para NW se comparados com aqueles das estratificações cruzadas de médio a grande portes das dunas barcanóides sotopostas.

Desse modo, pode-se concluir que a linha de costa estendia-se aproximadamente segundo E-W a NW-SE, situando-se as áreas-fonte continentais a NNE, onde se instalaram leques aluviais, disponibilizando fluxos densos gravitacionais que atingiam as porções litorâneas situadas a SSW, quando e onde eram retrabalhados pelas correntes de marés e ondas de tempestades em águas rasas, acima do nível de ondas normais.

\subsubsection{Geologia Estrutural}

Como ocorre nas demais bacias aqui analisadas, na Bacia de Pouso Alegre o acamamento reliquiar $\left(\mathrm{S}_{0}\right)$ guarda boa concordância estrutural com o trend principal do embasamento, assumindo atitude média de $\mathrm{N} 55^{\circ} \mathrm{E} 39^{\circ} \mathrm{SE}$ (Figura 4.3.17). Ele é interceptado por uma clivagem ardosiana $\left(\mathrm{S}_{1}\right)$ com atitude média de $\mathrm{N} 65^{\circ} \mathrm{E} 64^{\circ} \mathrm{SE}$, podendo-se notar que as direções são subparalelas às de $\mathrm{S}_{0}$, mas que os mergulhos, para o mesmo quadrante, são de maior ângulo.

Na Bacia de Pouso Alegre o estabelecimento do padrão deformaciona,l associado à sua fase de inversão e encurtamento, foi extremamente dificultado devido à falta de afloramentos in situ e, quando da ocorrência destes as exposições predominantemente metapsefíticas e metapsamíticas não dispunham de bons planos de falhas com espelhos estriados que permitissem traçar a história das sucessões de esforços e suas direções. Por outro lado, também, 


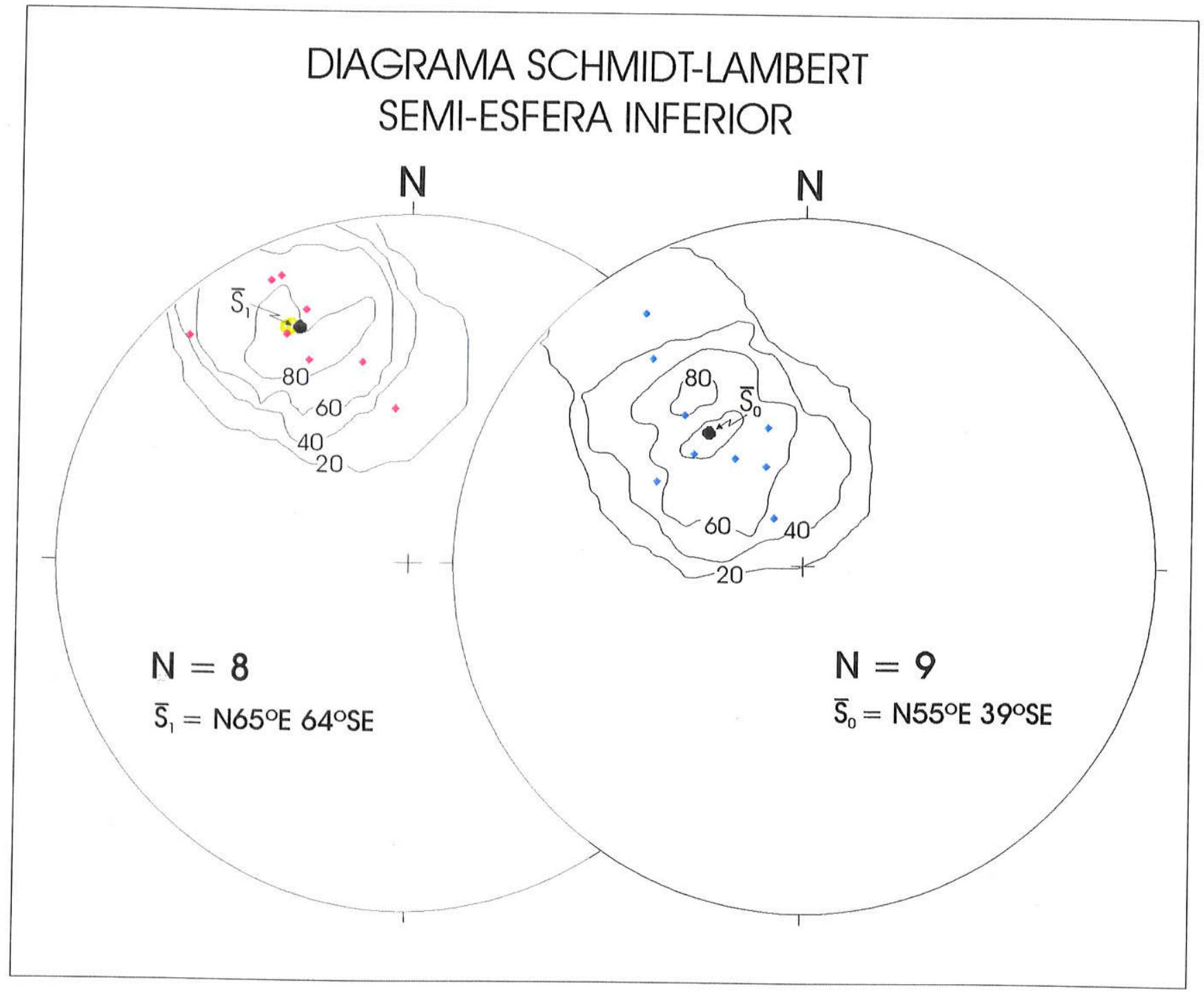

Figura 4.3.17 - Diagrama de igual área para as projeções polares do acamamento $\left(\mathrm{S}_{0}\right)$ e da clivagem ardosiana $\left(\mathrm{S}_{1}\right)$ medidos na Bacia de Pouso Alegre. $\overline{\mathrm{S}}_{0} \mathrm{e} \overline{\mathrm{S}}_{1}$ são, respectivamente, as atitudes médias do acamamento e da foliação metamórfica. 
nos metaconglomerados, quando in situ, as evidências deformacionais a partir de clastos foram poucas.

O formato aproximadamente triangular isósceles a trapezoidal da bacia, aliado à rede de falhas que a limita, é sugestivo de que as últimas deformações sofridas por esta foram impressas por binário de esforços sinistrogiro, entretanto, não foram diagnosticadas evidências contundentes que o comprovassem. Em alguns locais, nos metaconglomerados polimíticos da unidade basal a NW, rotações de clastos foram sugestivas de movimentação sinistrogira mas, nestes mesmos locais, ao lado de tais clastos, outros mostravam o predomínio de deformações associadas a binários destrogiros.

No ponto 52 (Figura 4.3.1), nos metaconglomerados com intercalações de metarenitos e metassiltitos (Figura 4.3.18), planos de falhas com mergulhos de $60^{\circ}$ para NW provocaram rejeitos inversos de até $40 \mathrm{~cm}$ nas intercalações metapelíticas/psamíticas, porém, devido à ausência de estriamentos nos planos de fraturas, não foi possível caracterizar a componente horizontal. No ponto 15 , em metassiltitos calcíferos, a clivagem ardosiana $\left(\mathrm{S}_{1}\right)$ intercepta com direção sub-paralela $\left(\mathrm{N} 70^{\circ} \mathrm{E} 70^{\circ} \mathrm{SE}\right)$ o acamamento reliquiar $\left(\mathrm{S}_{0}\right)$ de baixo ângulo de mergulho $\left(25^{\circ}\right.$ para sul), relação indicativa de vergência para NW. Exames meso e microscópicos mostraram que $\mathrm{S}_{1}$ comporta-se como uma clivagem de cisalhamento (microfraturas) que provoca rejeitos normais milimétricos (até $0,5 \mathrm{~cm}$ ) em $\mathrm{S}_{0}$, situando-se a lapa a sul e a capa norte (Figura 4.3.19). A componente horizontal não foi possível de ser estabelecida em campo. Com a análise de seção delgada orientada também não se obteve sucesso.

Nas rochas do embasamento situadas meridionalmente à bacia, com melhores exposições rochosas que as demais áreas de entorno, as observações tiveram mais sucesso. No ponto 18, no extremo WSW da bacia (Figura 4.3.1), onde afloram gnaisses facoidais a blastomiloníticos com intercalações de quartzitos, planos de falhas associados a cisalhamento rúptil-dúctil intercepta os gnaisses com atitude $\mathrm{N} 68^{\circ} \mathrm{E} 85^{\circ} \mathrm{SE}$. Os espelhos de falha contêm estrias de atrito suborizontais $\left(3-12^{\circ}\right.$ W). As demais feições cinemáticas dos espelhos (como degraus), associadas ao estriamento, forneceram indicações de movimentação lateral direita com pequena componente normal (plano de muito alto ângulo de caimento), que poderia ser extensiva para todo o falhamento que limita o embasamento com os metaconglomerados polimíticos da base da bacia. Em quartzitos, situados a poucas dezenas de metros a sudeste da exposição anterior, as mesmas relações foram observadas, entretanto o plano principal de cisalhamento assumia atitude $N 68^{\circ}$ $85^{\circ} \mathrm{NW}$ (alto ângulo de mergulho, mas para o quadrante NW). As estrias de atrito horizontais $\left(0^{\circ}\right)$ 


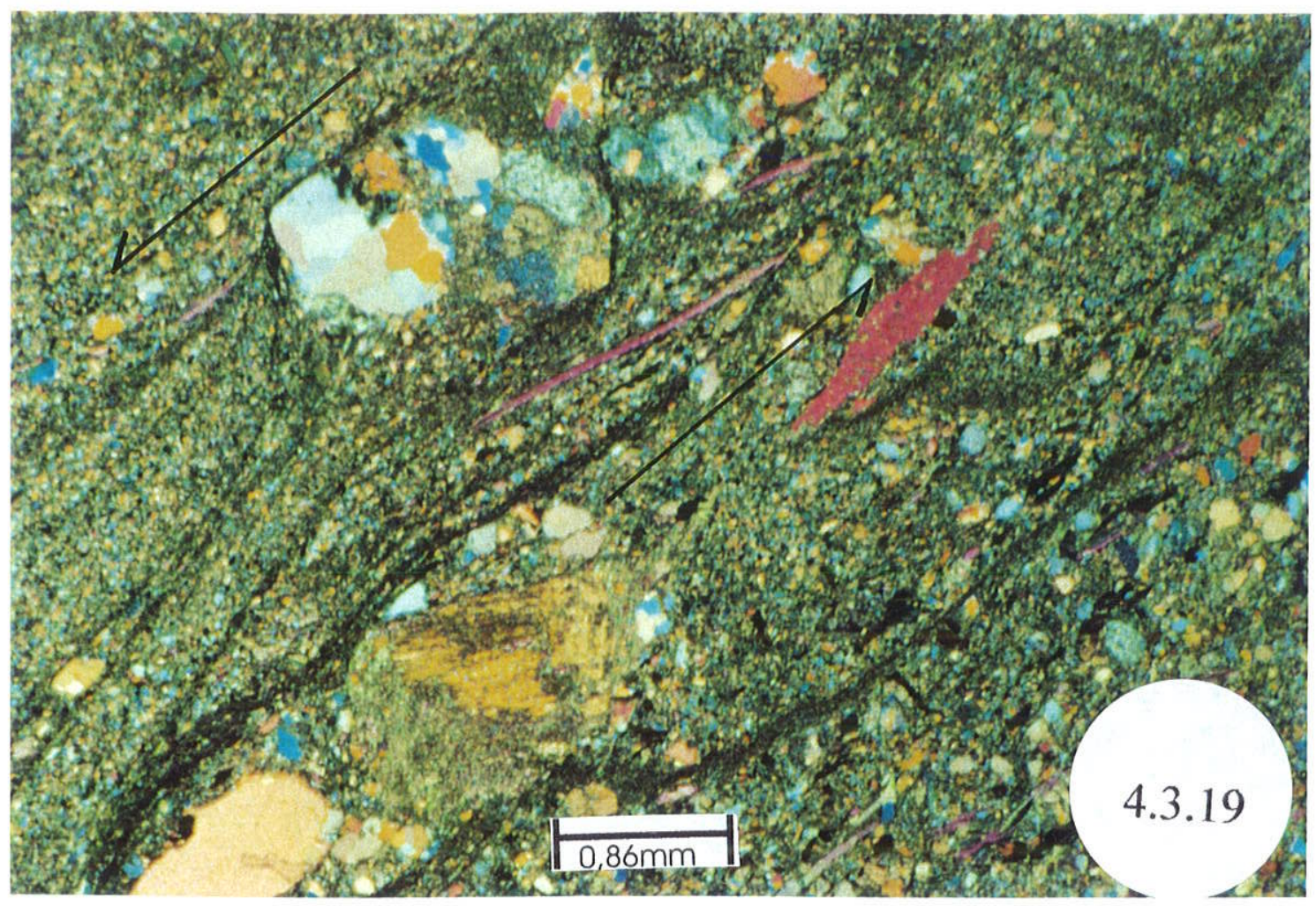

Figura 4.3.19 - Metassiltito arenoso calcífero apresentando feições deformacionais que caracterizam movimentação anti-horária ao longo de planos de microfraturas, dadas pela deformação em "z" das micas (mica fish), sombras de pressão em agregados quartzo-feldspáticos e pelas relações dos planos "Ss" e "Sc" de Berthé et al. (1979). O plano principal de deformação mergulha para sul $\left(70^{\circ}\right)$, conferindo à deformação principal da bacia (inversão e encurtamento com geração da foliação $S_{1}$ ) uma componente normal. Nicóis cruzados + placa gipso. Ponto 15 . 
foram superpostas por outras subverticais, indicativas de falhamento normal, situando-se o bloco alto a sul.

Mais a noroeste, no ponto 47, planos de falhas com alto ângulo de mergulho para NW $\left(75^{\circ}\right)$ e estrias de atrito suborizontais $\left(14^{\circ} \mathrm{W}\right)$ interceptam gnaisses facoidais, com feições indicativas de movimentação lateral direita com componente inversa. E, finalmente, no ponto 46, pouco mais a noroeste e ainda em rochas gnaissicas, planos de falhas (N66 $85^{\circ} \mathrm{NW}$ ) com estrias suborizontais $\left(10^{\circ} \mathrm{W}\right)$ e as demais feições do espelho indicaram movimentação lateral direita com componente inversa, com sobreposições no plano principal e em planos simétricos (com caimento para sul) de rejeitos normais.

Reconhecendo-se a escassez dos dados estruturais obtidos nos depósitos da Bacia de Pouso Alegre e no seu embasamento, mas, considerada a boa qualidade dos mesmos, é possível atribuir que a deformação principal imposta à bacia, durante a sua fase de inversão e encurtamento, obedeceu a um binário de esforços com vetores máximos compressivos orientados aproximadamente segundo E-W, provocando na rede de cisalhamentos preexistente e em novos sistemas gerados uma movimentação oblíqua, principalmente lateral direita com componente inversa. 


\subsection{Bacia de Cajamar}

Os depósitos da Bacia de Cajamar ocorrem sob a cidade de mesmo nome, na Região Metropolitana de São Paulo, distando cerca de $25 \mathrm{~km}$ da capital.

A análise de seus depósitos, a partir de testemunhos de sondagens de subsuperfície, foi motivada em outubro de 1986, quando, inesperadamente, processo cárstico com dolinamento foi deflagrado em plena área urbana de Cajamar, ocasionando o colapso do solo e de várias residências. O Instituto de Pesquisas Tecnológicas do Estado de São Paulo S. A. - IPT, solicitado pelo poder público realizou ali vários estudos (IPT 1987), sintetizados em Nakazawa et al. (1987), com o objetivo de prevenir futuros acidentes geológicos, recuperar a área acidentada e assegurar tranquilidade à população. Dentre os levantamentos geológico-geotécnicos, incluiu-se a perfuração de dezenas de poços profundos, distribuídos por quase toda a área urbana, incluindo entre eles várias sondagens rotativas com recuperação total ou parcial de testemunhos. A geologia da região, levando-se em conta esses dados adicionais obtidos por IPT (1987), foi revista com detalhamento de campo e se encontra sintetizada em Santoro et al. (1988), autores pertencentes, à época, aos quadros do IPT S.A.

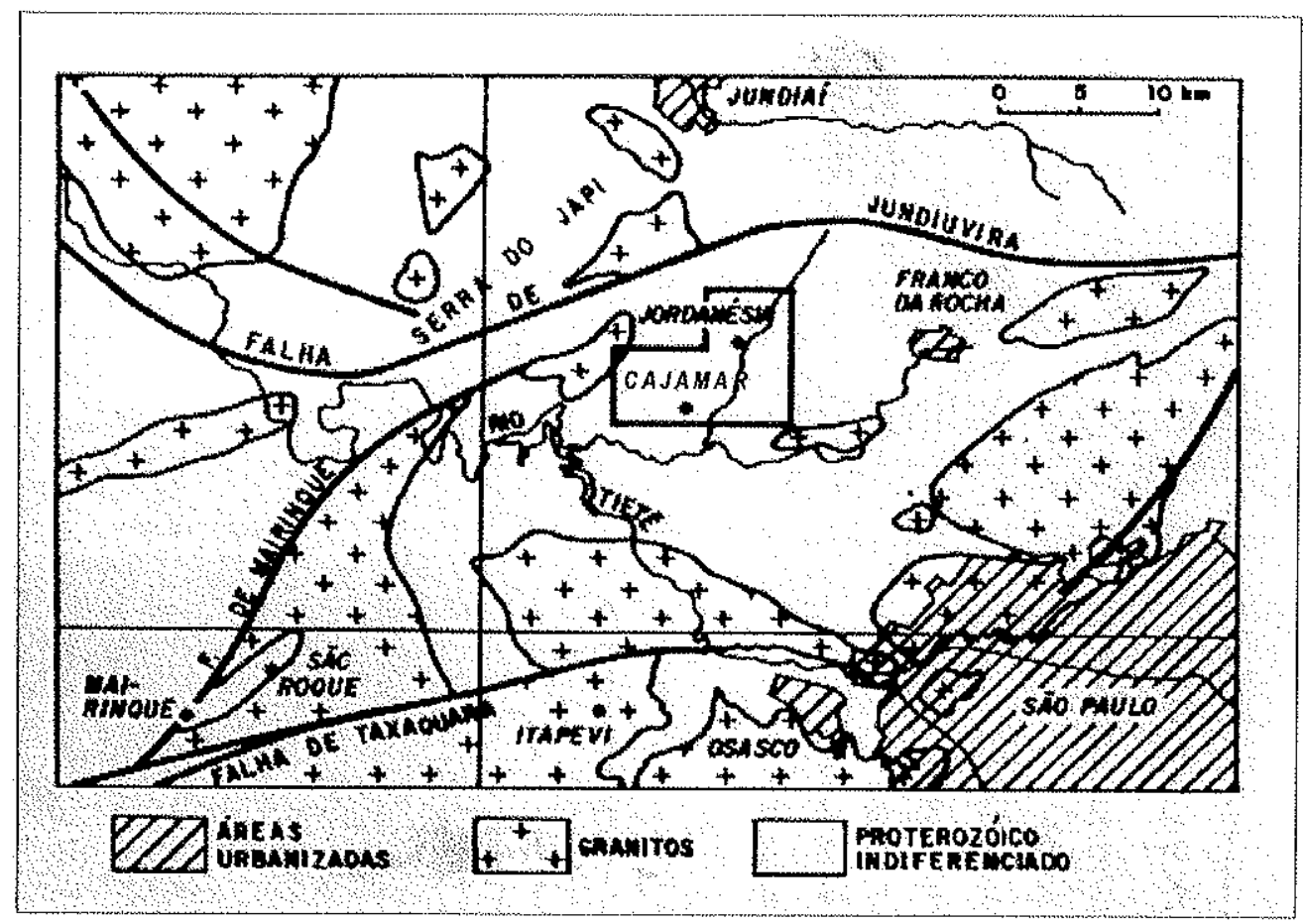

Figura 4.4.1 - Contexto geológico regional da Bacia de Cajamar (segundo Santoro et al. 1988).

A cidade de Cajamar está situada ao sul da Zona de Cisalhamento de Jundiuvira e, um pouco mais distante, a norte da Zona de Cisalhamento de Taxaquara (Figura 4.4.1). Entre essas ZCs afloram metassedimentos do Grupo São Roque e, possivelmente, metassedimentos e 
vulcânicas associadas do Grupo Serra do Itaberaba (Juliani et al. 1986), intrudidos por vários corpos granitóides sin a tardi-orogênicos.

No município de Cajamar e suas proximidades (Figura 4.4.2) predominam metapelitos e, subordinadamente, metapsamitos do Grupo São Roque ricos em intercalações de mármores calcíticos e dolomíticos, que há várias décadas são explotados pela indústria cimenteira e afins. Essas três unidades estruturam-se em sucessivas sinformas e antiformas que têm eixos orientados segundo NE-SW. A região urbana de Cajamar está assentada sobre alvéolo topográfico (Santoro et al. 1988) preenchido por depósitos coluvionares essencialmente argilosos, com cerca de $20 \mathrm{~m}$ de espessura, que no sentido das encostas dos morros são ricos em blocos e matacões (tálus). $\mathrm{Na}$ porção leste deste alvéolo, os depósitos coluvionares são colmatados e interdigitados com outros aluvionares, associados à calha do Ribeirão das Lavras que se dirige de NW para SE. Abaixo desses depósitos mais recentes ocorrem outros, siltosos e de cores variegadas e com fragmentos milimétricos a decimétricos de metarenitos, quartzo e filitos, interpretados como advindos principalmente da alteração de filitos (Santoro et al. 1988), cujas espessuras podem variar entre 30 e $80 \mathrm{~m}$, atingindo profundidades de até $100 \mathrm{~m}$. Nesta profundidade, atinge-se o solo de alteração de rochas carbonáticas marrom escuro, rico em cavidades de variadas dimensões preenchidas ou não por água, que transiciona para maiores profundidades à rocha sã, maciça, fraturada, de cor cinza e com cavidades preenchidas por água ou solo. Os autores atribuíram estruturação antiformal a esse pacote de rochas carbonáticas.

Hachiro \& Santoro (1996) interpretaram essa seqüência terrígeno-carbonática como singular, destacada do Grupo São Roque, de cujos metassedimentos distinguem-se quanto ao seu grau anquimetamórfico e à pouca deformação e quanto ao seu conteúdo litológico. Reinterpretaram os dados de subsuperficie obtidos por IPT (1987) e concluíram que os pacotes rochosos estruturam-se em blocos adernados ao redor de $25^{\circ}$ para $\mathrm{SE}$, por efeito de falhas normais escalonadas orientadas segundo NE-SW e responsáveis por grabens assimétricos, sítios de depósitos pelo menos cenozóicos, como pode ser visto na Figura 4.4.3.

Identificaram uma sucessão de estratos constituída, da base para o topo, de cerca de $200 \mathrm{~m}$ de calcarenitos cinza-claros, $50 \mathrm{~m}$ de calcarenito róseo claro e $20 \mathrm{~m}$ de dololutito róseo escuro (pink dolomites), conglomerados polimíticos com clastos fosfáticos e dolorruditos com clastos de dololutitos. Atribuíram sedimentação em plataforma rasa ou de planície de marés, com águas relativamente agitadas e pouco oxidantes até, pelo menos, a época de deposição dos carbonatos róseos. 


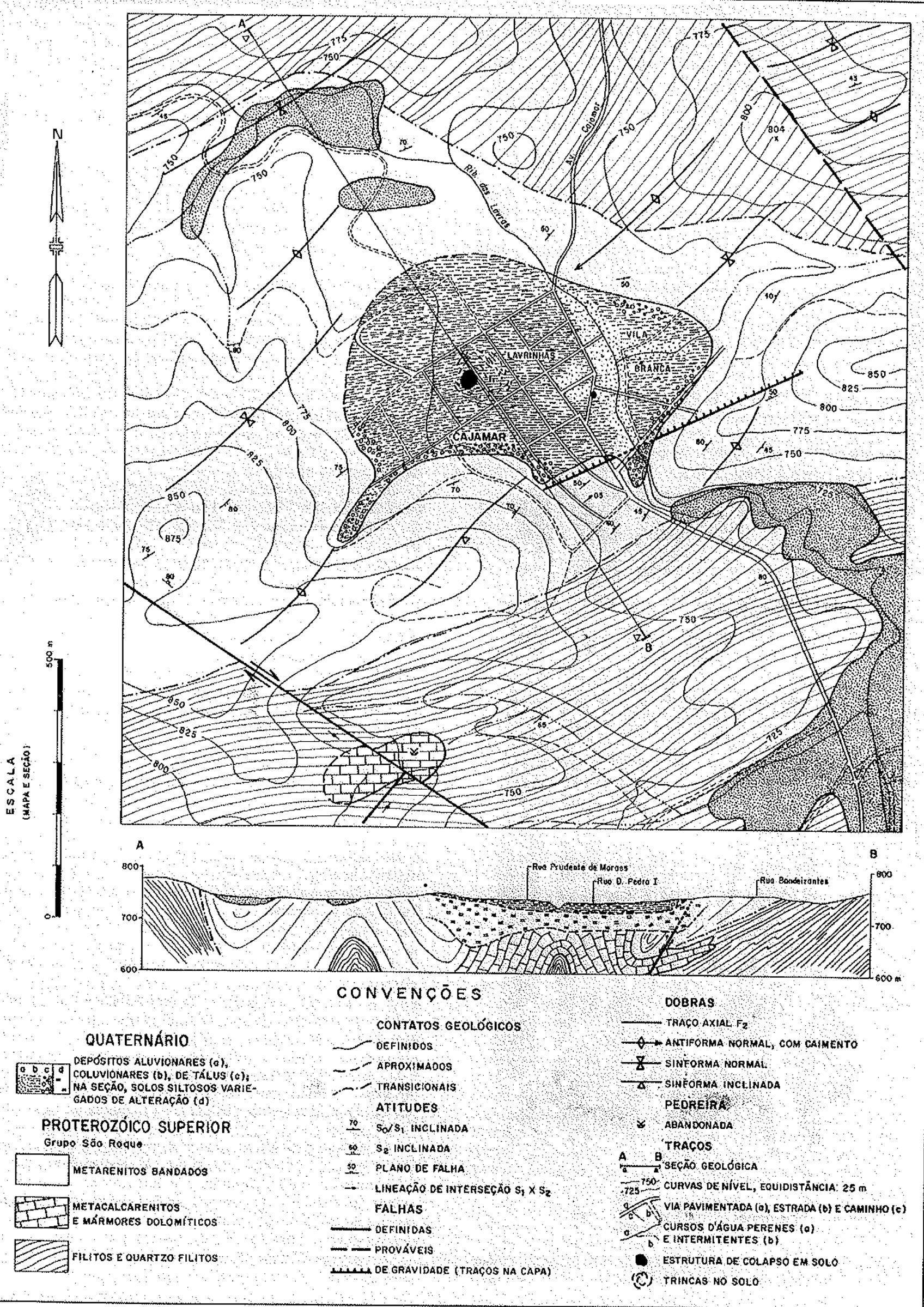

Figura 4.4.2 - Geologia do sítio urbano de Cajamar e áreas de entorno (segundo Santoro et al. 1988) 


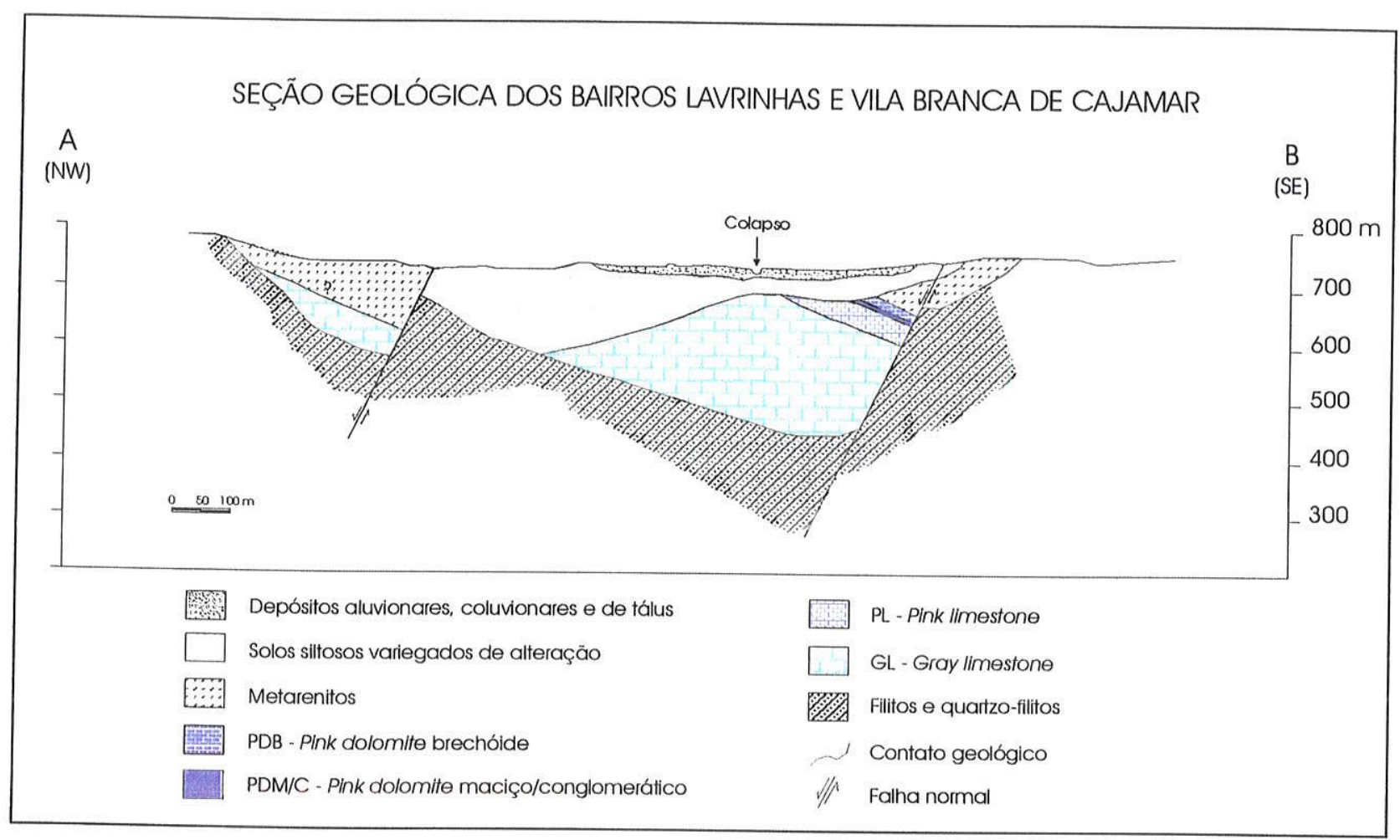

Figura 4.4.3 - Perfil geológico entre os bairros Lavrinhas e Vila Santa Branca de Cajamar, segundo Hachiro \& Santoro (inédito).

No presente projeto foram analisadas 7 amostras testemunhadas pelo IPT (1987), relacionadas na Tabela 4.4.1, na qual também constam 2 amostra de calcários do Grupo Açungui, Formação Água Clara, do Núleo Cablocos do PETAR (Parque Estadual Turístico do Alto Ribeira), utilizadas como referência para comparações analíticas.

Os metacalcarenitos intrabiomicroesparíticos (CJ-01 e CJ-02) são constituídos de cerca de 30-40\% de matriz/cimento com lama carbonática neomórfica, 55-70\% de componentes aloquímicos ( intraclastos, oncólitos e outros) e menos de $5 \%$ de clastos de quartzo, carbonato micro a macro cristalino e óxidos e hidróxidos de ferro. Os grãos aloquímicos variam de 0,2 a 0,6 $\mathrm{mm}$ de tamanho. A textura é granular micro a macro-cristalina. Difrações de raios-X revelaram predomínio de calcita sobre dolomita.

O metadolorrudito parcialmente silicificado (amostra CJ-03) tem matriz constituída por sílica microcristalina (50\%). Os componentes aloquímicos (50\%) são constituídos por grânulos 


\begin{tabular}{|c|c|c|c|}
\hline Amostra & Sigla IPT & Profundidade (m) & Classificação Petrogáfica \\
\hline CJ-O1 & SPR-01 & $50,61-51,14$ & Metacalcarenito (Intrabiomicroesparito) \\
\hline CJ-02 & SPR-06 & $56,47-58,50$ & Metacalcarenito (Intrabiomicroesparito) \\
\hline CJ-03 & SPR-30 & 62,50 & Metadolorrudito parcialmente silicificado \\
\hline CJ-04 & SPR-30 & 66,80 & Metaconglomerado \\
\hline CJ-05 & SPR-33 & 51,00 & Meta-quartzo arenito \\
\hline CJ-06 & SPR-37 & 66,00 & Metargilito \\
\hline CJ-07 & SPR-33 & 84,50 & Metacalcilutito \\
\hline \multicolumn{4}{|c|}{ Amostras da Formação Água Clara - Núcleo Cablocos do PETAR } \\
\hline NC-08B & Superfície & - & Metadolomicrito \\
\hline NC-23 & Superfície & - & Metacalcarenito esparítico \\
\hline
\end{tabular}

Tabela 4.4.1 - Relação das amostras analisadas neste projeto, com a sua localização e classificação petrográfica.

de intraclastos impregnados por óxidos e hidróxidos de ferro. Predomina dolomita sobre calcita, tratando-de a rocha de uma brecha intraformacional.

O metaconglomerado petromítico dolomítico brechado (amostra CJ-04) é constituído por $80 \%$ de clastos de quartzo, fragmentos líticos (quartzito, micrito, chert e siltito) e de feldspatos na fração areia grossa a muito grossa com grânulos, além de traços de muscovita, zircão e opacos, cimentados por carbonato micro a macrocristalino límpido (20\%). A análise de raios-X revelou grande predomíno de dolomita sobre a calcita.

A amostra de meta-quartzo arenito (CJ-05) é constituída por cerca de $85-90 \%$ de grãos de quartzo subangulosos e subarredondados de granulação areia fina e média, tendo em seus interstícios sílica microcristalina como cimento e minúsculas partículas de sericita, além de opacos, rutilo, biotita e hidróxidos e/ou óxidos de Fe.

Por último, a amostra de metargilito (CJ-06) é constituída essencialmente por sericita + argilominerais recristalizados (75-80\%) e por 15-20\% de quartzo, além de agregados de clorita + carbonato, opacos, zircão e muscovita. A difração de raios-X, em rocha-total apontou predomínio de quartzo sobre muscovita (sericita), traços de clinocloro e de dolomita.

O exame por catodoluminescência em algumas das amostras de Cajamar, mostrou que elas sofreram ampla impregnação/substituição por óxidos e hidróxidos de Fe e Mn, inexistindo praticamente porções não luminescentes. As cores CL (luminescência) transitaram do amarelo ao laranja para a calcita, quando impregnada por $\mathrm{Mn}^{2+}$, alcançando colorações marrom escuro a 
negro quando impregnada por $\mathrm{Mn}^{2+}+\mathrm{Fe}$. De acordo com Amieux (1982), as cores CL da calcita entre o amarelo e laranja indicam teores de $\mathrm{Mn} 2$ + entre 40-10.000 ppm na rocha e cores entre marrom a negro, teores superiores a $1 \%$ de $\mathrm{Fe}$, com predomínio de $\mathrm{Fe}^{3+}$ sobre $\mathrm{Fe}^{2+}$. Para os dolomitos, as cores CL variaram entre o amarelo, laranja e vermelho, mostrando presença de $\mathrm{Mn}^{2+}$ substituindo $\mathrm{Ca}$ ou $\mathrm{Mg}$. As análises geoquímicas (Anexo 1) mostraram nessas rochas teores de $\mathrm{Fe}_{2} \mathrm{O}_{3}$ entre 0,18 (CJ-01) a 2,18\%wt (CJ-03) e de $\mathrm{MnO}$ entre 0,06 a $0,18 \%$ wt, respectivamente. Enquanto isso, os teores de $\mathrm{CaO}$ e $\mathrm{MgO}$ variaram, respectivamente, entre 17,66 (CJ-03) a 50,13\%wt (CJ-01) e 2,17 (CJ-07) a 11,70\%wt (CJ-02).

Em função dessas características assumidas pelas rochas frente aos processos diagenéticos e/ou supérgenos (por águas meteóricas ricas em $\mathrm{Mn}$ e $\mathrm{Fe}$ ), optou-se por analisar os isótopos de $\mathrm{C}$ e $\mathrm{O}$ a partir da rocha total, considerando-se a grande probabilidade de serem tais contaminações/substituições adquiridas durante a deposição (no sítio original), tomando-se em conta os processos de ressurgência marinha que teriam coexistido durante a sedimentação, os quais também remobilizam o Fe e Mn de regiões anóxidas mais profundas. Os resultados obtidos (Tabela 4.4.2) mostram valores positivos, relativamente baixos, para $\delta \mathrm{C}^{13}$ PDB, que são indicativos de carbonatos de águas marinhas. Os valores de $\delta \mathrm{O}^{18}$ SMOw, muito altos (entre $+15 \mathrm{e}$ +19), também confirmam tal ambiente, se plotados no diagrama de Borscthevsky (1981, apud Zhang 1988), como visto na Figura 4.4.4. Neste diagrama encontram-se também plotados os resultados obtidos neste projeto das 2 amostras do Grupo Açungui (NC-08B e NC-23), além de outras analisadas por Frascá (1992) em mármores do grupos Açungui e São Roque e em rochas dos complexos Piracaia e Embu, de mais alto grau metamórfico e mais antigas. Nota-se que existe coerência entre os resultados, mesmo em se tratando de unidades diferenciadas no tempo e espaço e, considerando-se adicionalmente que o oxigênio seria mais susceptível que o $\mathrm{C}$ de sofrer variações frente aos processos diagenéticos e intempéricos de superfície.

\begin{tabular}{|c|c|c|c|c|c|}
\hline Amostra & $\delta \mathbf{O}^{\mathbf{1 8}}$ SMow & $\delta \mathbf{O}^{\mathbf{1 8}}$ PDB & $\delta \mathbf{C}^{\mathbf{1 3}} \mathbf{P D B}$ & \multicolumn{2}{|c|}{ Precisão } \\
\cline { 4 - 6 } & & & & Carbono & Oxigênio \\
\hline CJ-01 & +15.799 & -14.610 & +0.322 & 0.006 & 0.013 \\
\hline CJ-02 & +19.504 & -11.016 & +1.405 & 0.004 & 0.005 \\
\hline CJ-03 & +16.271 & -14.153 & +0.690 & 0.004 & 0.003 \\
\hline CJ-04 & +18.601 & -11.892 & +0.310 & 0.004 & 0.004 \\
\hline NC-08B & +20.811 & -9.748 & -1.788 & 0.005 & 0.008 \\
\hline NC-23 & +21.642 & -8.942 & +2.755 & 0.006 & 0.012 \\
\hline
\end{tabular}

Tabela 4.4.2 - Resultados analíticos de isótopos estáveis de C e O para as amostras analisadas da Bacia de Cajamar e do Subgrupo Lageado, região do PETAR. 


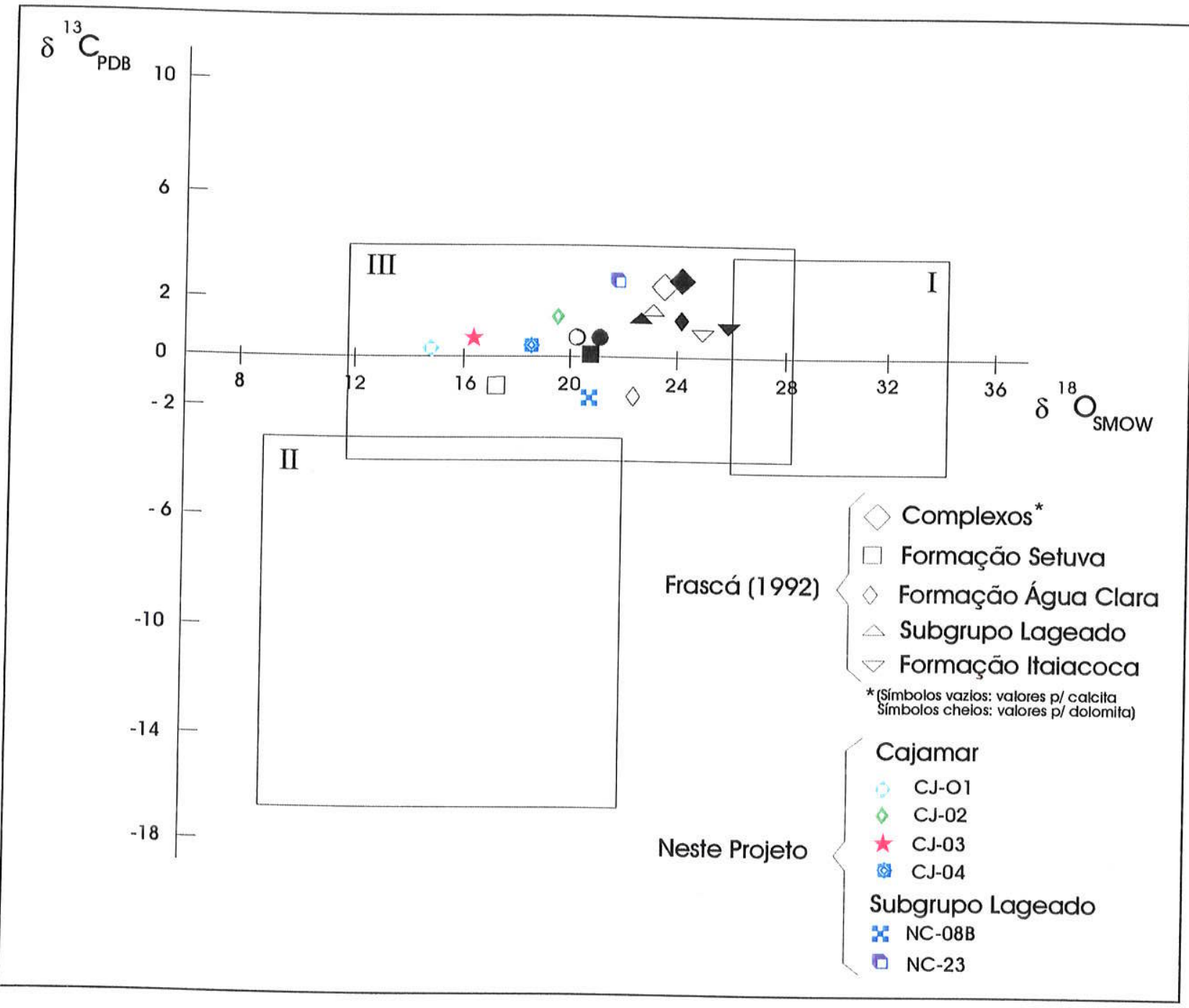

Figura 4.4.4- Diagrama de variações $\delta^{18} \mathrm{O}_{\text {Smow }} \times \delta^{13} \mathrm{C}_{\mathbf{P D B}}$ (segundo Borscthevsky et al. 1981, apud Zhang 1988) para os campos de: I - Carbonatos marinhos, II - Carbonatos de água doce, e III - Carbonatos marinhos pré-cambrianos metamorfizados. Nele foram plotados os dados de Frascá (1992) e deste projeto.

Comparando as amostras analisadas com os diagramas de comparações mundiais de rochas carbonáticas (Figura 4.4.5) de Keith \&Weber (1964) e com os histogramas de Veiser \& Hoefs (1976), na Figura 4.4.6, observa-se que os resultados obtidos são compatíveis com aqueles dos autores, considerando-se tanto o ambiente marinho para a deposição, quanto os intervalos prováveis de idades para a sedimentação.

Pode-se com isso, provavelmente, concluir que a introdução de Fe e Mn nas amostras, seja a partir de processos diagenéticos ou por águas meteóricas, não influenciaram substancialmente os valores de $\delta{ }^{13} \mathrm{C}$ e de $\delta{ }^{18} \mathrm{O}$ originais existentes no sítio da deposição, ou seja das águas oceânicas em circulação. Refletem esses valores as condições químicas aproximadas do meio original. 


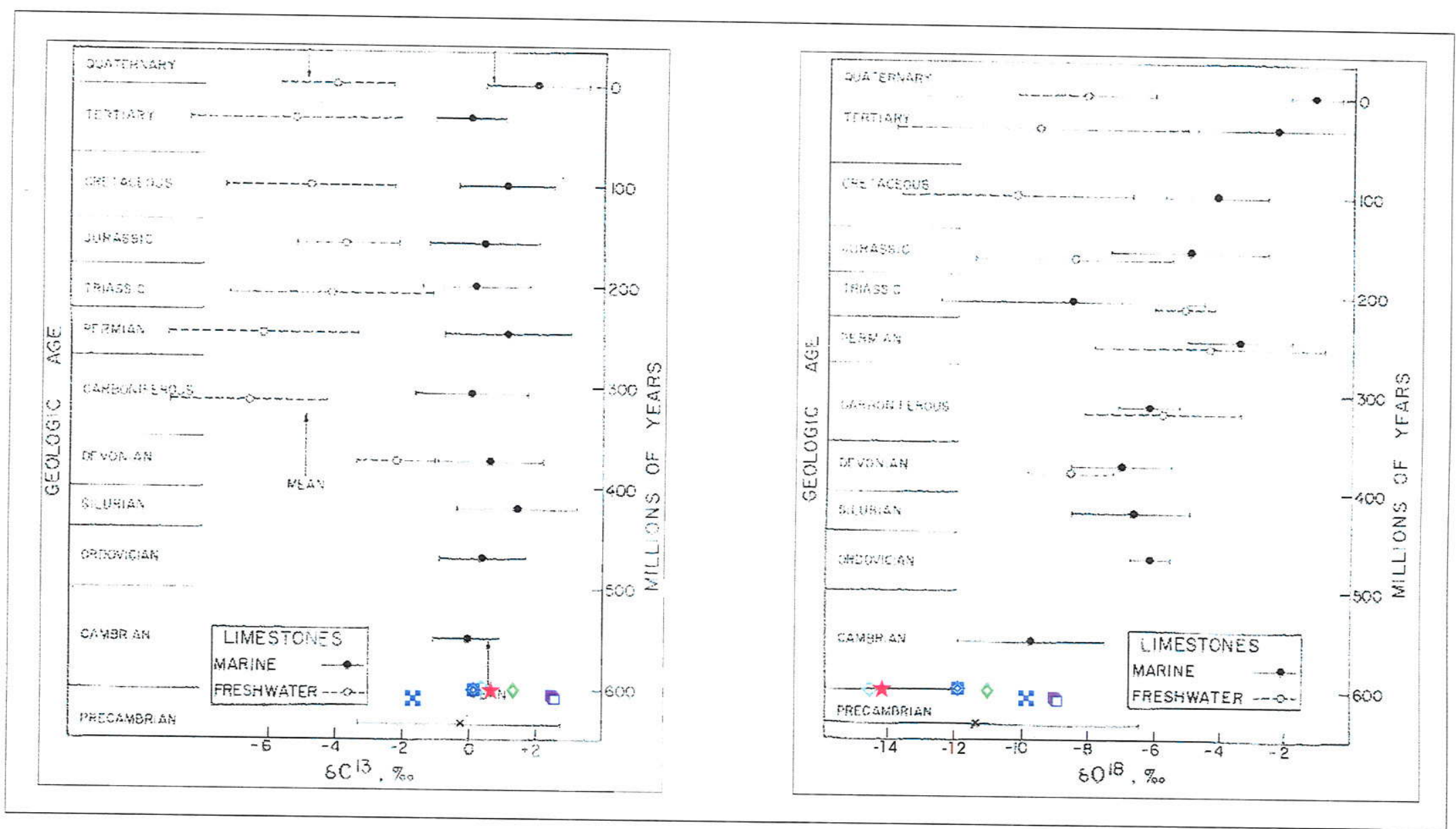

Figura 4.4.5 - Composição isotópica média de carbonatos marinhos e de água doce, tendo-se em conta as variaçães de $\delta^{13} \mathrm{C}_{\mathrm{PDB}}$ e $\delta^{18} \mathrm{O}_{\mathrm{PDB}}$ em função das idades geológicas (Keith \& Weber 1964). A legenda para os dados plotados da Bacia de Cajamaré a mesma da Figura 4.4.4. 


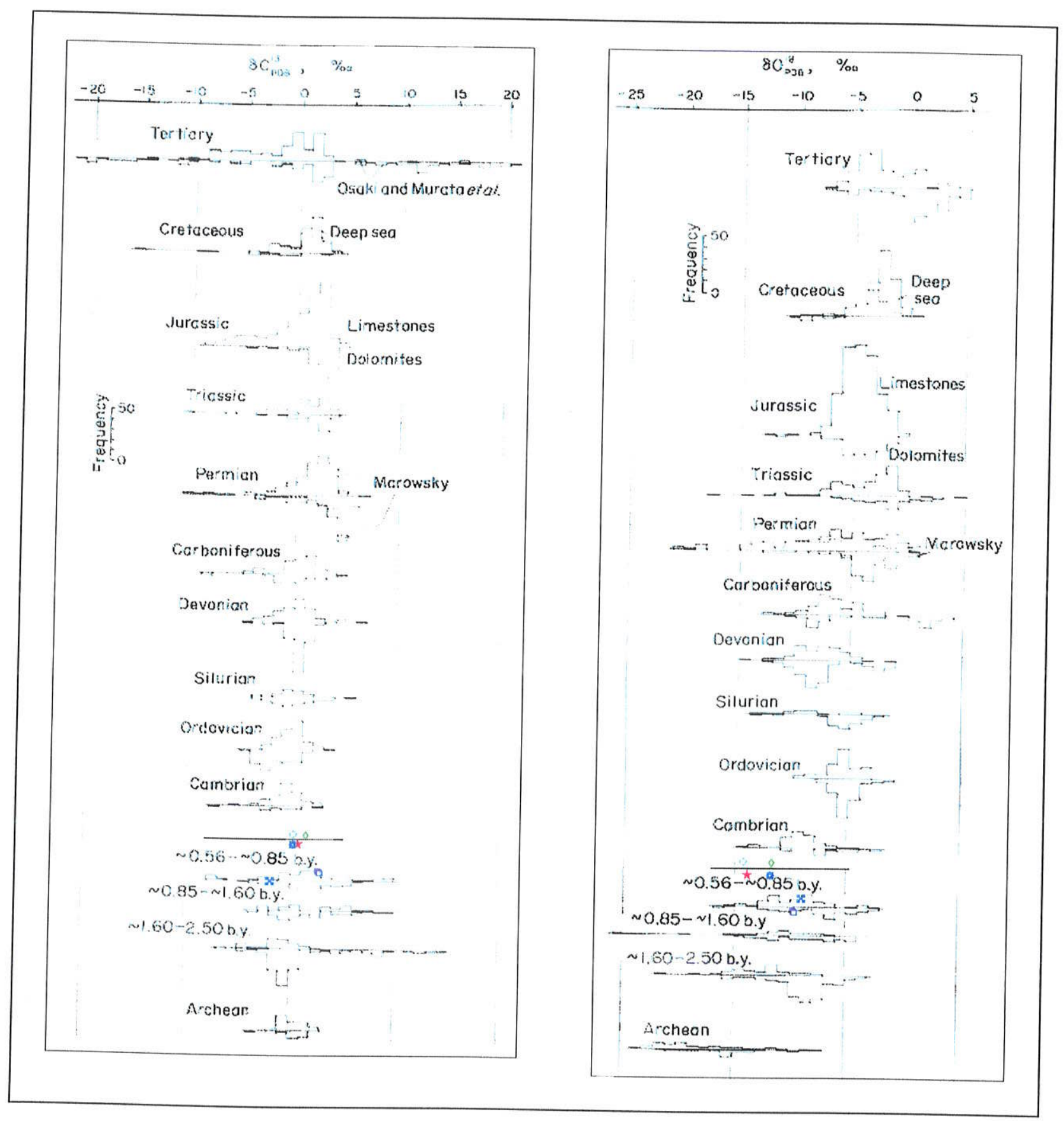

Figura 4.4.6 - Histogramas de variações $\delta^{13} \mathrm{C}_{\mathrm{PDB}}$ e $\delta^{18} \mathrm{O}_{\mathrm{PDB}}$ para rochas carbonáticas versus a idade geológica, resultante da compilação de dados mundiais de Veizer \& Hoefs (1976). Histogramas acima das linhas de referência representam rochas calcíticas e abaixo destas, dolomíticas. Os dados de Cajamar foram plotados segundo linha de referência especial, entre o Cambriano e o intervalo de idades $\sim 0.56-\sim 0.85$ b.y. As amostras do Subgrupo Lageado referenciamse a este último intervalo. A legenda é a mesma da Figura 4.4.4. 


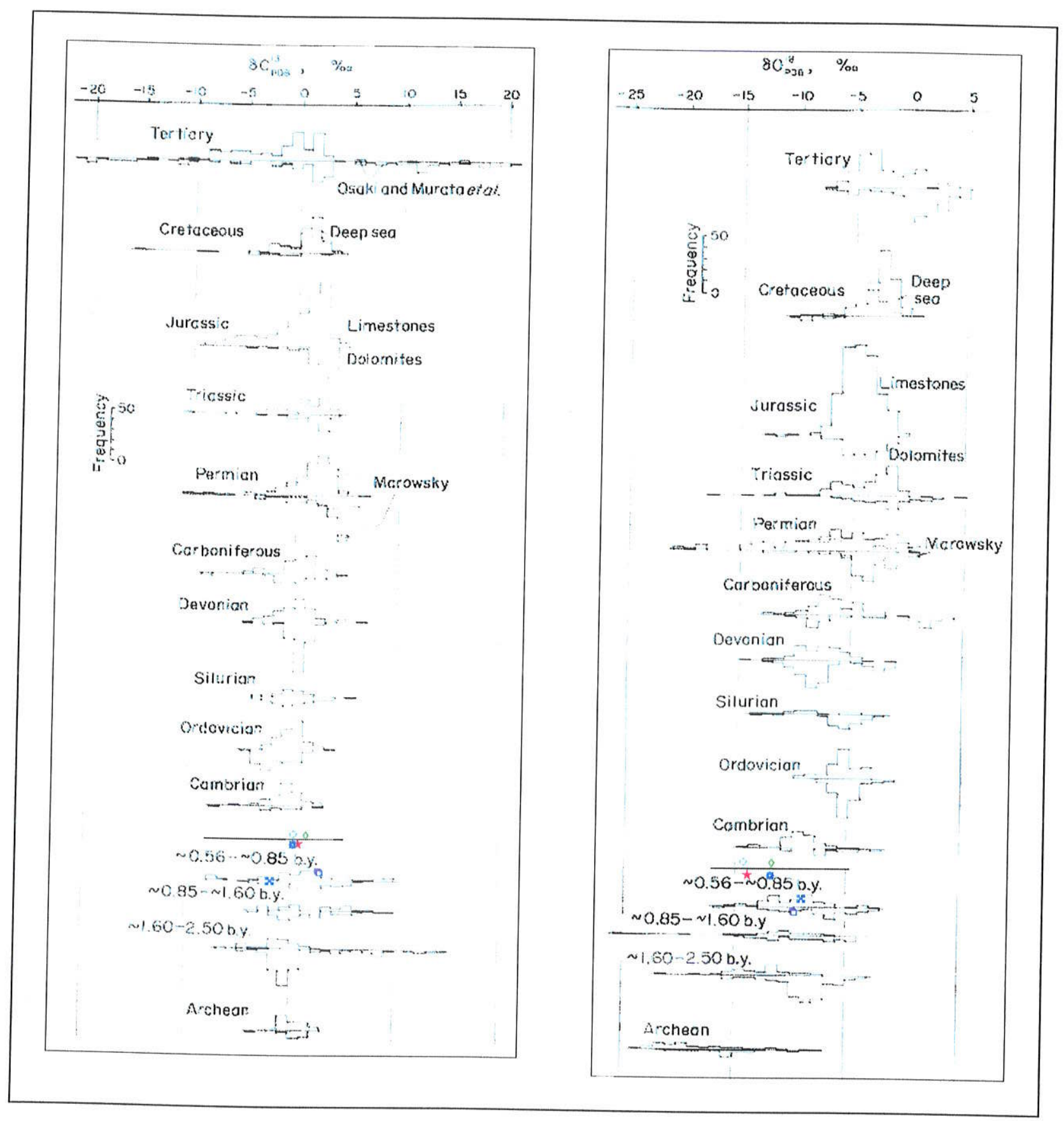

Figura 4.4.6 - Histogramas de variações $\delta^{13} \mathrm{C}_{\mathrm{PDB}}$ e $\delta^{18} \mathrm{O}_{\mathrm{PDB}}$ para rochas carbonáticas versus a idade geológica, resultante da compilação de dados mundiais de Veizer \& Hoefs (1976). Histogramas acima das linhas de referência representam rochas calcíticas e abaixo destas, dolomíticas. Os dados de Cajamar foram plotados segundo linha de referência especial, entre o Cambriano e o intervalo de idades $\sim 0.56-\sim 0.85$ b.y. As amostras do Subgrupo Lageado referenciamse a este último intervalo. A legenda é a mesma da Figura 4.4.4. 
Nas rochas carbonáticas da Bacia de Cajamar foram identificados, ainda expeditamente, pelos profs. Claudio Gaucher e Peter Sprechmann, da Faculdad de Ciencias da Universidad de la Republica de Montevideo, Uruguai, a partir do exame de seções delgadas, os microfósseis Cloudina riemkeae GERMS 1972 (amostras CJ-01 e CJ-02) e Titanotheca coimbrae GAUCHER \& SPRECHMANN 1999 (amostras CJ-06, de metassiltito - Figuras 4.4.7 e 4.4.8 - e CJ-03, de dolorrudito).

O microfóssil Cloudina ocorre também no Grupo Corumbá (Zaine 1991 e Boggiani 1998), em carbonatos (rudstones) da Formação Tamengo, unidade média-superior desse grupo, associada com transgressão marinha da fase $d r i f t$ da bacia, onde a disponibilidade de oxigênio em águas rasas favoreceram tal vida metazoária, inclusive de Corumbella werneri. Ocorre também Cloudina na base do Grupo Arroyo del Soldado, no Uruguai, em meta siltitos bandados da Formação Yerbal, associada ao máximo transgressivo da unidade (Gaucher \& Sprechmann 1999), concentrada sua ocorrência aos níveis de maior oxigenação.

O microfóssil Titanotheca coimbrae, assim denominado por Gaucher \& Sprechmann (1999) em homenagem póstuma a Armando Márcio Coimbra, com quem participaram de trabalhos de campo no Brasil e Uruguai, ocorre em dolorruditos (pink dolomites), conglomerados petromíticos dolomíticos brechados e em metargilitos da Bacia de Cajamar. No Grupo Arroyo del Soldado, ocorrem também na Formação Yerbal, em siltitos laminados, associados com águas relativamente rasas e oxigenadas. O microfóssil Cloudina, ainda não determinado com segurança, ocorreria em calcarenitos da Bacia de Cajamar.

Dentro desse quadro comparativo, e reconhecidamente ainda preliminar, os depósitos carbonático-terrígenos remanescentes da Bacia de Cajamar constituem fortes candidatos ("o elo perdido") de uma autêntica plataforma carbonática que coadjuvara com remanescentes continentais e marinhos rasos das bacias do Pico de Itapeva, de Eleutério e de Pouso Alegre, pelo menos.

Adicionalmente acrescenta-se como de grande importância o fato da concorrência de eventos de ressurgência marinha fosfogênicos (carbonatos róseos e conglomerados com clastos fosfáticos), e mesmo de $\mathrm{Fe}$ e $\mathrm{Mn}$, com a participação de fósseis de reconhecida distribuição mundial durante o Neoproterozóico, que implicará na busca de novas modelagens paleogeográficas e tectônicas, diversas daquelas até então assumidas. 
Figura 4.4.7 - Titanotheca coimbrae GAUCHER \& SPRECHMANN 1999 em metassiltito arenoso da Bacia de Cajamar. Indivíduo adulto com carapaça constituída por aglutinado de microcristais de rutilo e abertura substituída por sílica microcristalina (indicada pela seta). Nicóis descruzados. Amostra CJ-06.

Figura 4.4.8 - Indivíduo jovem com forma mais esférica, apresentando, também, abertura silicosa substituída por sílica microcristalina. Nicóis cruzados. Amostra CJ-06. 

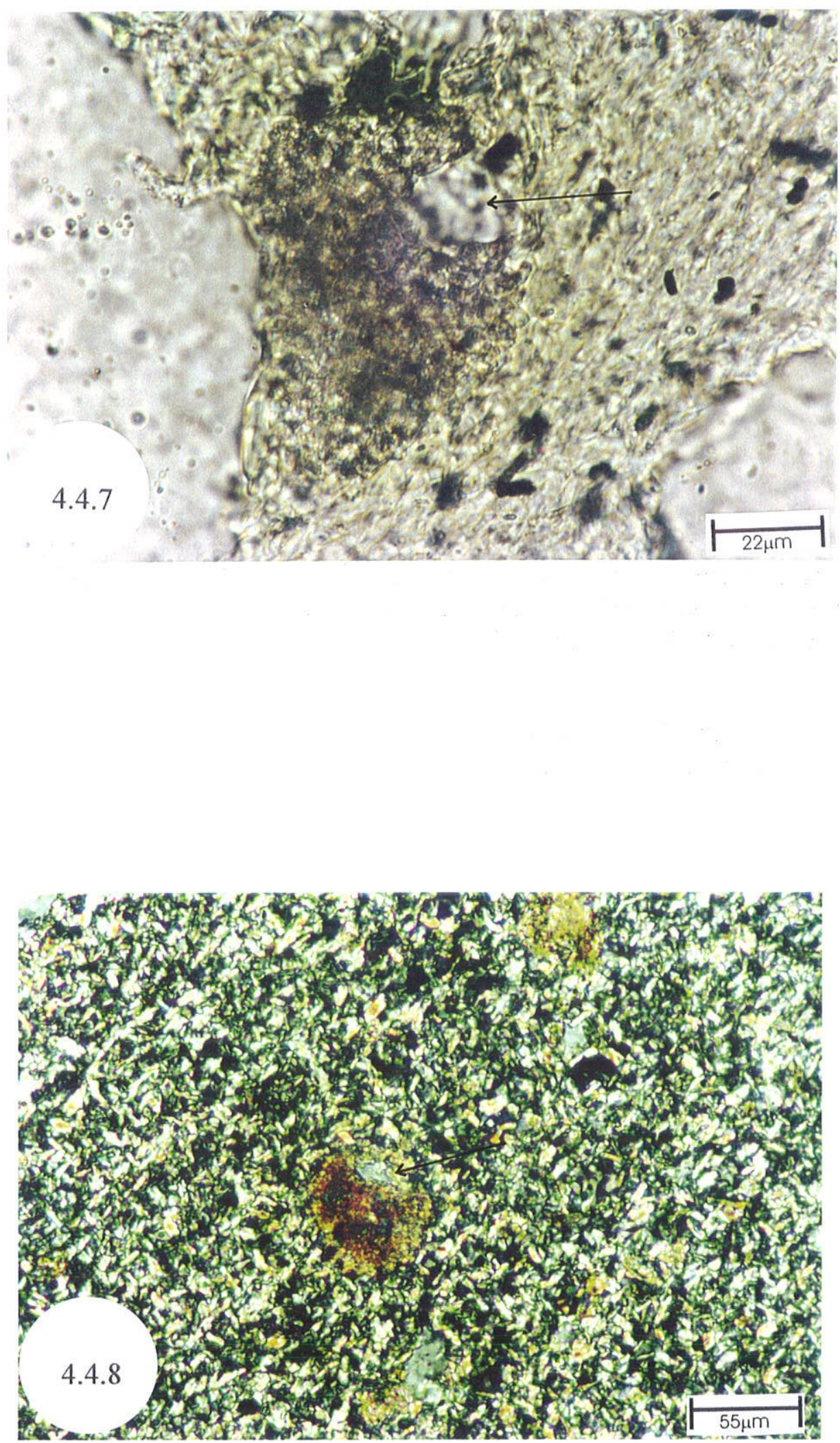


\subsection{BACIA DO QUATIS}

Os sedimentos da Bacia do Quatis situam-se nas cimeiras da Serra da Boa Vista, remanescentes do Planalto Guapiara (Ponçano et al. 1981, apud Campanha et al. 1985) avançados até oeste de Cajati, no sul do Estado. Situados em área de muito difícil acesso, os depósitos aflorantes perfazem área de cerca de $5,5 \mathrm{~km}^{2}$. Descrevem, grosso modo, um semicírculo, cujo diâmetro coincide com a Falha do Braço Grande que os limita a SE com os xistos da Seqüência Cajati. Nas porções mais setentrionais os limites são coincidentes com as bordas erodidas do planalto remanescente. Sobrepõem-se aí sobre xistos e migmatitos da Seqüência Turvo-Areado e Complexo Pré-Setuva, respectivamente, através de inconformidade. Campanha \& Sadowski (1999) reuniram os xistos e filitos da Seqüência Cajati e Turvo-Areado no Complexo Setuva; os migmatitos da Seqüência Turvo-Areado e do Complexo Pré-Setuva foram por eles enfeixados no Complexo Gnáissico Migmatítico (Figura 4.5.1).

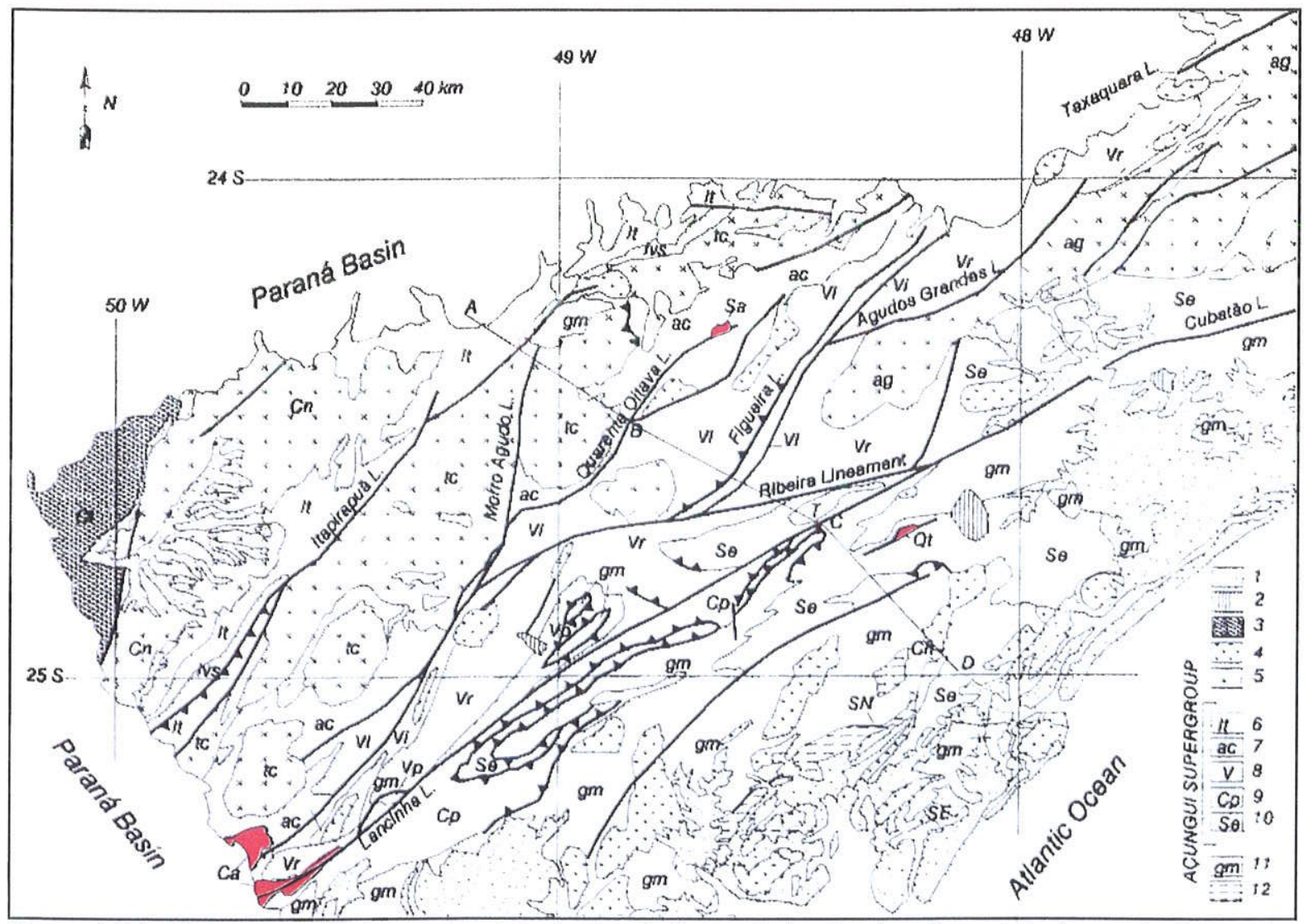

Figura 4.5.1 - Contexto geológico regional das bacias do Samambaia, Quatis e Camarinha (segundo Campanha \& Sadowski (1999).

Os poucos dados estruturais existentes obtidos por Campanha et al. (1985), indicam que o acamamento reliquiar orienta-se predominantemente segundo NE-SW, com variações subordinadas na direção WNW-ESE e NNW-SSE, na porção centro-oeste da bacia, e orientações 
segundo NNE-SSW, na porção norte desta (Figura 4.5.2). Os mergulhos das camadas variam entre 20 e $77^{\circ}$ no rumo sudeste predominantemente, com variações para WSW e NNE, na porção centro-oeste e atingem $65^{\circ}$ no rumo noroeste, na porção norte da bacia. Pouco metamorfizados, os depósitos são interceptados por tênue clivagem ardosiana oblíqua ao acamamento reliquiar $\left(\mathrm{S}_{0}\right)$, com direção e mergulho médios, respectivamente, de $\mathrm{N} 60^{\circ} \mathrm{E}$ e $60^{\circ}$ para $\mathrm{NW}$.

A clivagem ardosiana é melhor destacada nos termos pelíticos. Os seus planos são determinados pela orientação preferencial de cristais neoformados de sericita e clorita, além de epídoto e calcita, e por cristais de minerais micáceos detríticos, que às vezes se apresentam crenulados por efeito deste metamorfismo. Campanha et al. (1985) consideraram que o metamorfismo desenvolvido na Bacia do Quatis e nas rochas do Grupo Açungui são semelhantes (baixo grau na zona da clorita-biotita instável) e que possivelmente foram síncronos ou, que o mesmo evento metamórfico afetou a ambos. Deve ser considerado, no entanto, que apesar das possíveis similaridades metamórficas, os estilos e as fases deformacionais são incompatíveis, uma vez que as rochas do Grupo Açungui apresentam nítidos dobramentos e redobramentos, aos quais correspondem distintas foliações plano-axiais, o que de modo algum se verifica nos depósitos da Bacia do Quatis.

As relações entre as atitudes do acamamento e da foliação metamórfica, observadas ao nível do afloramento, indicam situações sinformais e antiformais tanto para sul quanto para norte. Apesar disso, Campanha et al (1985) não verificaram quaisquer dobramentos no campo. No caso da Bacia do Quatis, a exemplo do que ocorre na Bacia Eleutério, parece também que os processos geradores da foliação não se relacionaram a um achatamento e dobramentos associados. O elemento motriz responsável pela geração da clivagem ardosiana foi o cisalhamento simples, associado a binário de esforços com eixos máximos compressivos predominantemente suborizontais.

Campanha et al. (1985) e Campanha \& Teixeira (1986) identificaram metaconglomerados polimíticos, metarcóseos, metarenitos, metassiltitos e metargilitos nos depósitos da Bacia do Quatis. Os termos conglomeráticos distribuem-se, preferencialmente, pela porção SE, contígua à Falha do Braço Grande. Os demais ocorrem intercalados por toda a área, onde predominam termos arenosos, arcoseanos ou feldspáticos, sobre os demais. Devido às características do levantamento de semi-detalhe realizado e às condições muito ínvias para realizá-lo, os autores não conseguiram precisar o empilhamento estratigráfico dos litotipos presentes e, também, estabelecer análise sistemática das fácies ou sistemas deposicionais envolvidos. O levantamento realizado à época emprestou ênfase muito grande à análise estrutural 


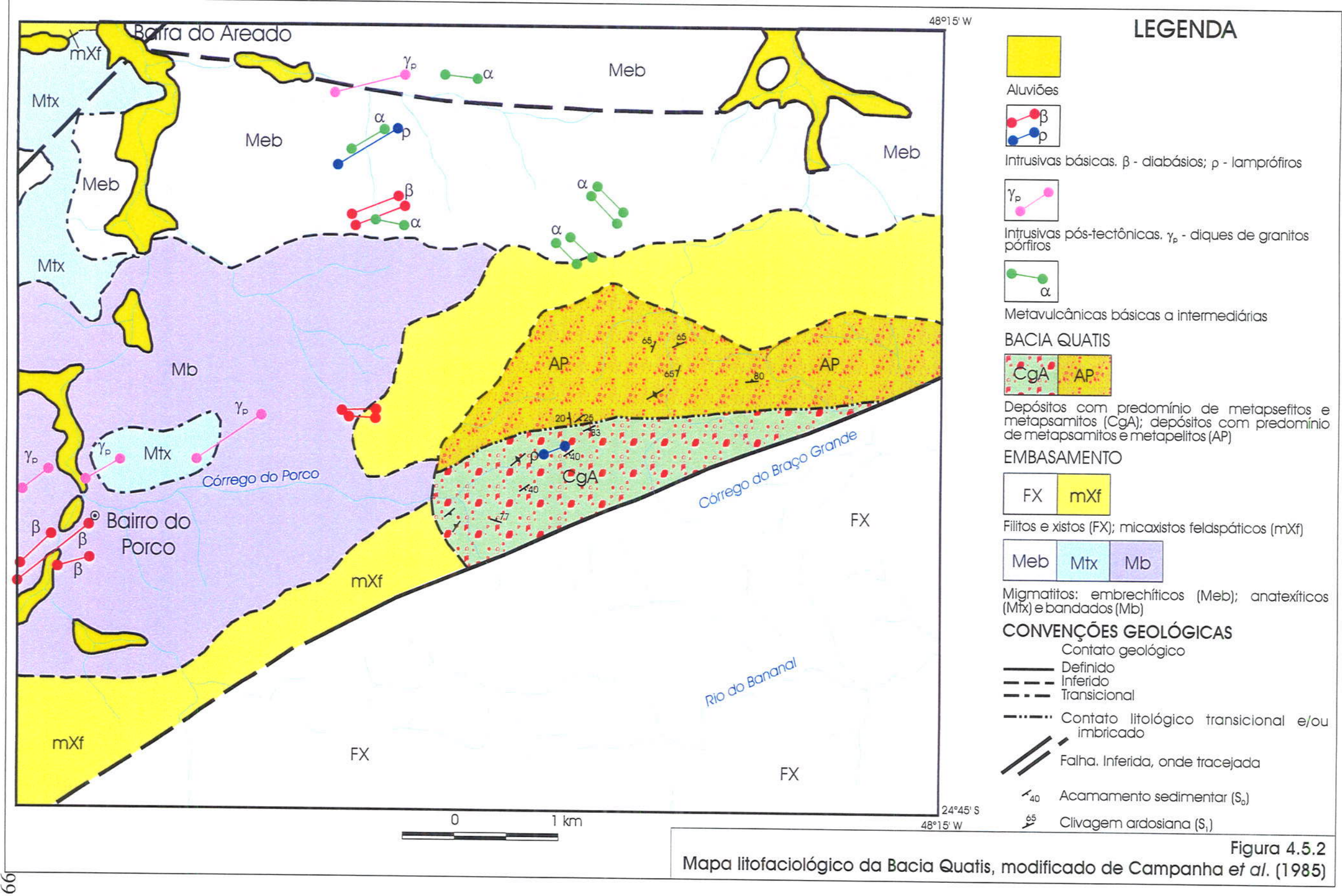


e tectônica, em detrimento de enfoques sedimentológicos e estratigráficos, também essenciais para a análise dessas bacias. As considerações doravante formuladas sobre a Bacia do Quatis estarão limitadas por esses condicionantes herdados, uma vez que não existiram novas investigações de campo, além daquelas realizadas por Campanha et al. (1985) e sintetizadas em Campanha \& Teixeira (1986).

Campanha et al. (1985) e Campanha \& Teixeira (1986) aventaram a hipótese de que as áreas-fonte responsáveis pelo fornecimento de detritos à bacia estiveram situadas a SSE, pelo menos, tendo em vista a ocorrência preferencial de metaconglomerados polimíticos acompanhando a borda sudeste atual desta, coincidente com o traçado da Falha do Braço Grande. Ao mesmo tempo, esta feição estrutural teria condicionado o preenchimento da bacia e a distribuição das fácies sedimentares. Mas, considerando as ponderações do parágrafo anterior, tal hipótese seria apenas especulativa.

Os metaconglomerados polimíticos ocorrem geralmente em camadas decimétricas a métricas. Seu arcabouço tem granulação variável de blocos decimétricos até seixos e grânulos, subangulosos a subarredondados, de rochas gnáissicas, granitóides, quartzíticas, quartzosas, rochas básicas, xistos e filitos, envoltos por matriz intersticial de um metarcóseo lítico, com granulação areia grossa, constituída de grãos de gnáisses, clorita-xistos, sericita-filitos, quartzitos, feldspatos (plagioclásio e feldspato alcalino) e quartzo, envoltos por massa fina recristalizada, provavelmente a partir de um cimento, constituída por epídoto, clorita e calcita, conforme observações efetuadas em duas seções delgadas por Campanha et al. (1985). O contato dos metaconglomerados com as rochas xistosas do Complexo Setuva é de natureza tectônica, através da Falha do Braço Grande. Ao longo desta desenvolveram-se brechas cataclásticas e milonitos sobre os epimetamortitos e sobre os xistos.

Os metaconglomerados e os demais litotipos da bacia, setentrionalmente à borda sudeste, dispõem-se em intercalações centimétricas a métricas, onde a estratificação plano-paralela, em geral, é bem definida. No mesmo sentido setentrional, parece haver uma tendência de decréscimo granulométrico dos litotipos. Essas características sugerem passagens gradacionais e interdigitadas entre os mesmos.

Os metarcóseos têm granulação que varia de areia fina a grossa com grânulos, com grãos clásticos angulosos a subarredondados de quartzo e feldspatos, fragmentos líticos de granitóides, xistos e metabasitos e intraclásticos angulosos de metassiltitos e metargilitos. A relação em volume de quartzo+feldspato com fragmentos líticos é variável, definindo metarcóseos e metarcóseos líticos. A matriz ocorre ocupando os espaços intergranulares, encontrando-se 
totalmente recristalizada a partir de argilo-minerais originalmente disponíveis e dos demais minerais do arcabouço. É constituída de cristais de epídoto, clorita e muscovita/sericita, suborientados preferencialmente, e calcita que, localmente, pode predominar em até 95\% do volume da matriz. Dispersos pela matriz ainda podem ocorrer grãos clásticos de turmalina, titanita (leucoxenizada) e zircão, além de pontuações de sulfetados (pirita e calcopirita). Os metarcóseos adquirem coloração cinza-esverdeado, quando sãos, e coloração marrom a bege, quando alterados.

Os metarenitos têm granulação fina e são constituídos essencialmente por quartzo, com frações variáveis de micas e feldspatos, e com coloração cinza-claro a esbranquiçada.

Os metargilitos e metassiltitos ocorrem, em geral, intercalados como camadas ou lâminas de espessuras centimétricas a sub-centimétricas, que exibem colorações arroxeadas a cinzaesverdeado para os metargilitos e cinza-claro a marrom avermelhadas para os metassiltitos. $\mathrm{Na}$ interface entre lâminas ou camadas pode ocorrer uma película constituída por hidróxidos de Fe e Mn. Os metassiltitos, microscopicamente, são constituídos de grãos clásticos de muscovita, biotita, quartzo e feldspatos imersos em matriz recristalizada, constituída de sericita e clorita. Em quantidade menor ou como traços ocorrem opacos, titanita, zircão, turmalina, rutilo, apatita e epídoto. Os cristais recristalizados de sericita e clorita apresentam-se suborientados, definindo uma foliação incipiente, geralmente oblíqua ao acamamento.

As informações disponíveis sobre a Bacia do Quatis não permitem muitas inferências sobre a sua evolução tectônica e sedimentar. Além de uma provável área-fonte situada a sul, como proposto por Campanha et al. (1985) e Campanha \& Teixeira (1986), tendo como suporte para tal hipótese o predomínio de fácies rudáceas situadas ao longo da borda tectônica sudeste, demais ensaios paleogeográficos e paleoambientais são mais dificultosos de serem realizados. No entanto, as características dos depósitos apontam para a conjugação de ambientes de leques aluviais, associados a áreas tectonicamente emersas, com outros subaquosos, provavelmente marinhos, a exemplo do que ocorre com as demais bacias, até agora melhor analisadas, como as de Camarinha, de Eleutério, do Pico de Itapeva e de Pouso Alegre, além da Bacia de Cajamar que, ao que tudo indica, representa resto de plataforma carbonática de um embaciamento marinho raso, que parece ser comum a todas elas. 


\subsection{BACIA DO SAMAMBAIA}

Os metassedimentos da Bacia do Samambaia situam-se a cerca de $8 \mathrm{~km}$ a sudeste de Guapiara, região sul do Estado, às margens do ribeirão de mesmo nome, contribuinte do Rio Apiaí-Guaçu (Petri \& Suguio 1969). Associam-se ao Lineamento Quarenta-Oitava (Figuras 4.5.1 e 4.6.1), conquanto suas relações com este não estejam elucidadas (Campanha 1991). São constituídos de metaconglomerados polimíticos e oligomíticos, metarenitos conglomeráticos e metarenitos arcoseanos a feldspáticos, sobrepostos às rochas metassedimentares do Grupo Açungui (Marini et al. 1967), apesar de que as relações com estes últimos não se encontram bem definidas (Petri \& Suguio 1969).

Petri \& Suguio (1969) descreveram em afloramento com 3,5 metros de espessura, situado à margem direita do Ribeirão Samambaia, na região de Guapiara, sete seqüências com estruturas gradacionais, da base para o topo, de metaconglomerados para metarenitos conglomeráticos ou não. Detiveram suas descrições com maiores detalhes às características dos termos conglomeráticos da base das seqüências. Identificaram nos metaconglomerados polimíticos seixos e grânulos pouco arredondados de feldspatos, quartzo, quartzito (com até $8 \mathrm{~cm}$ de tamanho), xisto, filito, metarritimitos arenosos com muita matriz argilo-sericítica, metarenito com abundante matriz sericítica, metarenito conglomerático, granito, calcáreo e calcarenito, dispostos caoticamente. Identificaram uma matriz arenosa, arcoseana, e, mais raramente, uma matriz siltosa (sericita+clorita) envolvendo os clastos. Em seções delgadas, analisadas microscopicamente, os autores verificaram a seguinte constituição modal dos metaconglomerados: $45 \%$ de feldspatos, $15 \%$ de quartzitos, $10 \%$ de quartzo, $8 \%$ de filitos, $6 \%$ de calcarenitos, $5 \%$ de metarenito conglomerático, $4 \%$ de metarenito, $3 \%$ de granito, $2 \%$ de metarritmito, $1 \%$ de calcáreo e $1 \%$ de xisto, denotando a grande imaturidade mineralógica da rocha.

Nos termos psamíticos, segundo os autores, a estruturação em camadas é mais conspícua. Nestes, o quartzo predomina em $55 \%$ da rocha, seguido de $25 \%$ em feldspatos, $15 \%$ em quartzitos, $4 \%$ em filitos e $1 \%$ em granito.

Chamou a atenção de Petri \& Suguio (1969) o baixo arredondamento dos clastos, tanto nos psefitos quanto nos psamitos, a grande porcentagem de clastos de feldspatos róseos sem indícios de alteração intempérica pretérita, a matriz arcoseana e cimento escasso. Segundo os autores, tais aspectos são sugestivos de pequeno transporte, desde a área-fonte predominantemente granítica até o sítio deposicional. Para as sete sequêencias gradacionais 


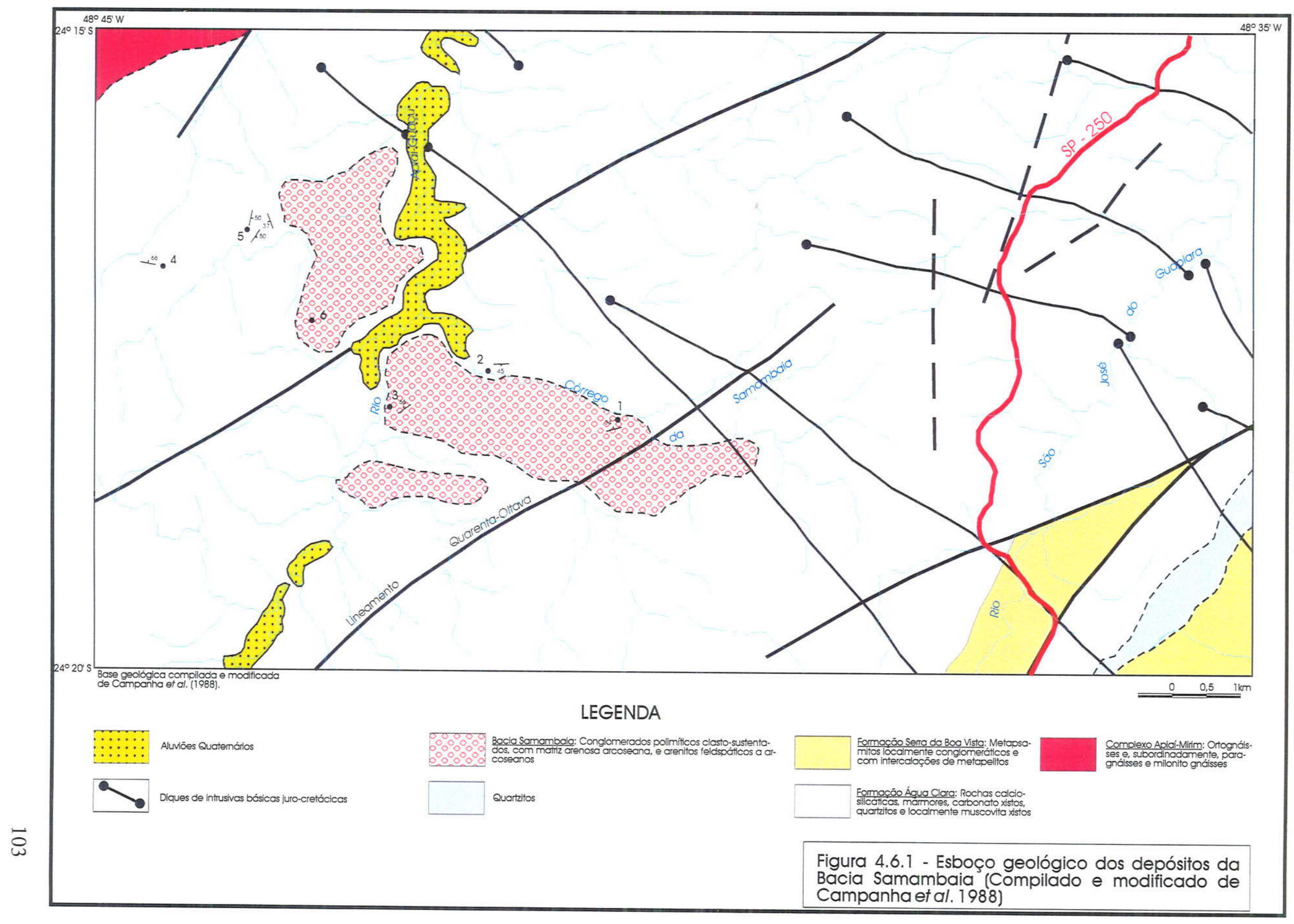


empilhadas sucessivamente, atribuíram uma origem relacionada com fluxos intermitentes encosta abaixo que inundavam depressões bem próximas da área-fonte.

Campanha et al. (1988) descreveram na bacia ciclos sedimentares granodecrescentes, com espessura de 0,5 a 1 metro, onde as menores frações granulométricas são de areia grossa, sempre situadas no topo da seqüência. Verificaram entre os grãos clásticos do arcabouço fragmentos líticos de quartzitos, sericita-quartzo xistos, calcáreos e filitos e a presença marcante de plagioclásios e de feldspatos alcalinos, todos subangulares, mas com boa seleção para o topo. A matriz perfaz até $20 \%$ do volume da rocha, constituída de grãos de carbonato recristalizado a partir de fragmentos líticos de mesma natureza, sericita recristalizada principalmente a partir das frações argilosas e quartzo microcristalino, envoltos por cimento constituído por óxidos de ferro. Os autores concluíram pelo pequeno transporte e baixo retrabalhamento dos sedimentos durante a deposição, em bacia que imputaram natureza "molássica".

Campanha et al. (1988) e Campanha (1991) contextualizaram as ocorrências dơs depósitos Samambaia associadas ao Lineamento Quarenta-Oitava. Este se constitui em uma das ramificações setentrionais do Lineamento Ribeira, que atravessa a porção sul do Estado de São Paulo e leste paranaense (Figura 4.5.1), ao longo da Faixa Apiaí-Ribeira. Campanha (1991) considerou que a gênese desses depósitos e de outros correlatos esteve provavelmente associada ao sistema de cisalhamento transcorrente, que se sobrepôs a dois outros eventos deformacionais anteriores. Nas cunhas formadas pela união de zonas transcorrentes desenvolveram-se tarditectônicamente, bacias de afastamento (pull-apart) em locais de transtração. No entanto, o autor não discorreu com maiores detalhes sobre as estruturas existentes ao nível mesoscópico. Campanha et al. (1988) observaram que os depósitos da Bacia do Samambaia não evidenciam compactação extrema nem deformação progressiva a ponto de desenvolverem estruturas penetrativas, apesar da marcante recristalização das frações argilosas da matriz para sericita envolvendo os clastos. Petri \& Suguio (1969) consideraram que estes metassedimentos se diferenciam daqueles do Grupo Açungui em suas características sedimentológicas, estratigráficas e tectônicas (pós-orogênicos), apesar de estarem perturbados tectonicamente.

As exposições rochosas são muito escassas na região. Apenas 3 pontos de afloramentos foram descritos durante os levantamentos de campo (pontos SA-01, SA-03 e SA-06). O acamamento reliquiar, onde medido, tem direção $\mathrm{N} 84^{\circ} \mathrm{E} 34^{\circ} \mathrm{NW}$ (ponto $\mathrm{SAm}-01$ ) e $\mathrm{N} 54^{\circ} \mathrm{E} 66^{\circ} \mathrm{NW}$ (SA-03). Não foram observadas as relações de contato desses depósitos com o embasamento. Entretanto, a partir dos poucos dados de $S_{0}$ para os depósitos Samambaia, pode ser visto na Figura 4.6.1, que estes são estruturalmente discordantes das atitudes de $\mathrm{S}_{0}$ do embasamento 
metassedimentar (constituído de rochas calciossilicáticas, mármores e metabásicas da Formação Água Clara), com direções WNW e NNW. Pôde-se então inferir discordância angular e erosiva entre os depósitos Samambaia e o embasamento.

Foram descritos metaconglomerados e metarenitos. Os metaconglomerados são polimíticos clasto-sustentados, com arcabouço constituído de grânulos, seixos e calhaus (raros matacões) de quartzitos, granitóides (gnaisses bandados e leucogranitos turmaliníferos), metarenitos, filitos, calciossilicáticas, pegmatóides, metabásicas, quartzitos marrom escuros manganesíferos/ferríferos(BIF?) e K-feldspatos, além de seixos intraclásticos argilo-siltosos angulosos, marrom escuros. Calhaus e matacões tendem à subangulosidade, enquanto os seixos apresentam-se subarredondados a arredondados. A matriz, apenas intersticial aos clastos, é arenosa grossa arcoseana. Intercalações arenosas com 5 a $15 \mathrm{~cm}$ de espessura podem ocorrer nos conglomerados (ponto SA-01). Variam tais intercalações de areias grossas a areias finas marrom escuras, ambas arcoseanas, que, localmente, exibem estratificação cruzada de baixo ângulo, com fluxo direcionado para NW. Aparentemente os arenitos assumiram espessuras maiores, a julgar pela exposição no leito da estrada (SA-06) onde predominam, em alguns metros, areias de granulação média a grossa, arcoseanas, com grânulos de K-feldspatos e com coloração marrom carmim claro.

Chama a atenção a grande semelhança entre os conglomerados da Bacia do Samambaia (Figura 4.6.2) e os conglomerados da Bacia Camarinha (Figura 4.7.4), em especial aqueles situados no corpo noroeste desta última, na região do Rio dos Motas. As similaridades dizem respeito ao conteúdo clástico, relações matriz/arcabouço e, com maior destaque a coloração marrom escuro com tonalidades arroxeadas ou amareladas de ambos, fornecida pela cimentação por óxidos de Fe. Distando de cerca de $160 \mathrm{~km}$ uma da outra, essas bacias têm em comum o embasamento constituído essencialmente pelas mesmas unidades rochosas do Grupo Açungui, intrudidas a noroeste pelas rochas do Complexo Granítico Três Córregos, no contexto geológico do Cinturão de Dobramentos Apiaí (vide Figura 3.1). Estruturalmente, ressaltando-se as poucas observações realizadas na Bacia do Samambaia, existe concordância estrutural entre o acamamento reliquiar $\left(\mathrm{S}_{0}\right)$ de ambas: com direção NE-SW e mergulhos para NW. Tais similaridades, poderiam sugerir que houve preteritamente uma continuidade entre ambas, considerando-se, adicionalmente, que o estilo estrutural e tectônico do embasamento é invariável desde a região de Camarinha, Grande Curitiba, até o sul do Estado de São Paulo, na faixa compreendida entre os lineamentos Lancinha-Cubatão, a sul (Figura 4.5.1), e Itapirapuã- 
Taxaquara, a norte (Campanha \& Sadowski 1999). Entretanto, apenas estudos complementares de maior abrangência regional e detalhe cartográfico poderiam esclarecer o problema.

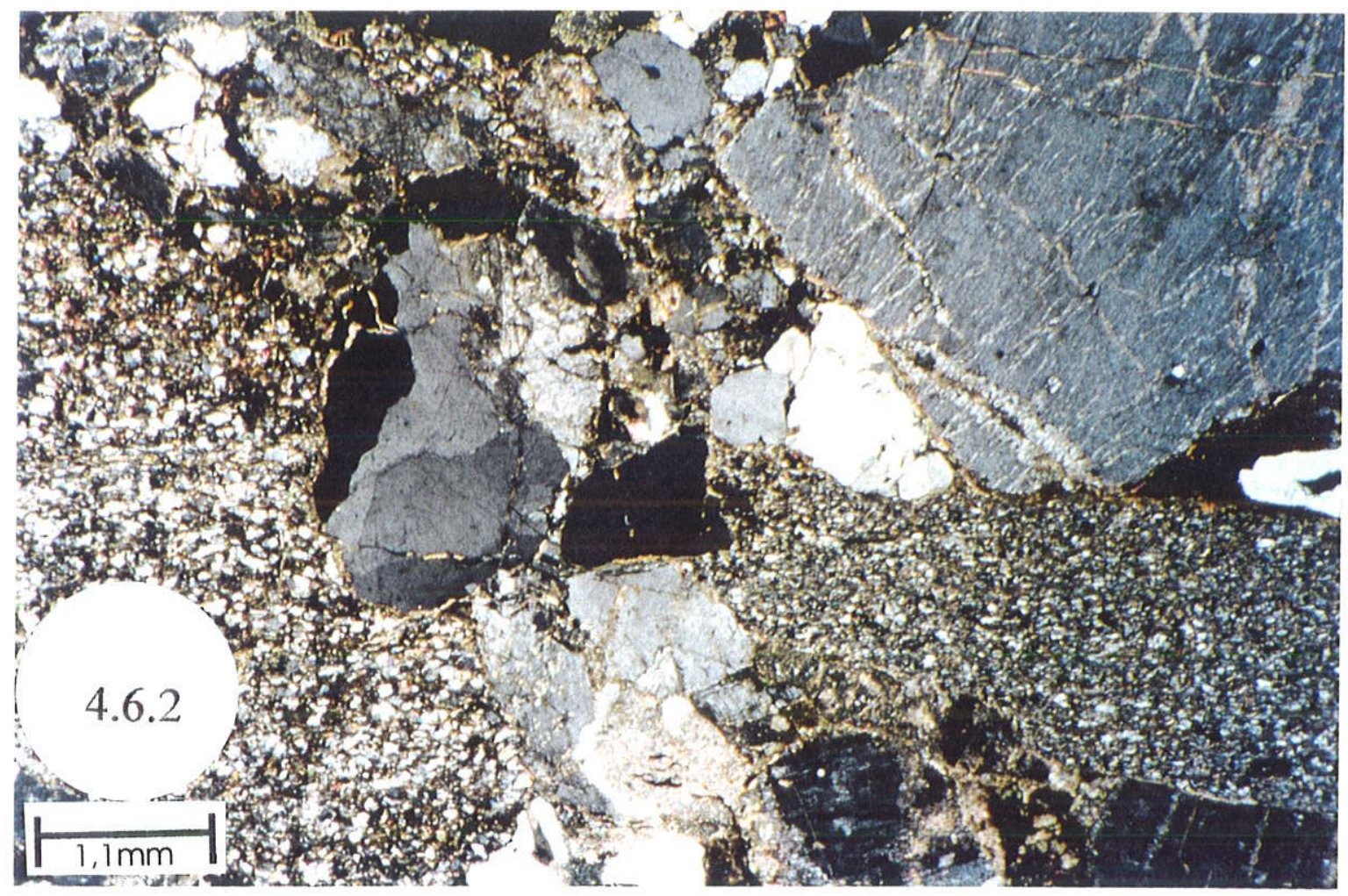

Figura 4.6.2 - Detalhe da matriz de metaconglomerado polimítico, da Bacia do Samambaia, ocupando apenas os interstícios entre grânulos de feldspatos, quartzo e intraclastos de metassiltitos. Notar a deformação por compactação nos intraclastos e rúptil sobre grãos de quartzo e de feldspatos, principalmente. Notar também a presença de óxidos/hidróxidos de Fe, como cimento nos intraclastos. Nicóis cruzados. 


\subsection{BACIA DE CAMARINHA}

Os depósitos da Bacia de Camarinha foram descritos sumariamente pela primeira vez por Muratori \& Fuck (1965, apud Fuck 1966, Muratori 1966 e Popp 1972), durante a realização do XIX Congresso Brasileiro de Geologia, no Rio de Janeiro. Denominaram de "Formação Camarinha" uma seqüuência de siltitos com intercalações de conglomerados brechóides e, mais raramente, argilitos e arcóseos, cuja seção tipo (Figura 4.7.1B) encontra-se na região de Camarinha, a WNW de Campo Largo, entre as localidades de Alto do Purunã e Taquaralzinho (Fuck 1966 e Muratori 1966). Estratigraficamente situaram-na, com discordâncias angulares, sobre as rochas do Grupo Açungui e sob os arenitos devonianos da Formação Furnas. Discriminaram-na, também, do embasamento, pelo metamorfismo ausente e pela presença freqüente de clastos do Açungui nos conglomerados, o que lhes permitiu situá-la como unidade do Pré-Devoniano, com dúvidas sobre a sua extensão até o Pré-Cambriano.

Muratori et al. (1967) propuseram que os depósitos Camarinha seriam remanescentes de sedimentação tardiorogênica relacionada a uma evolução geossinclinal, mais propriamente remanescentes molássicos. A sedimentação teria ocorrido em depressões originadas pelo soerguimento orogênico do Grupo Açungui, entre $600 \mathrm{Ma}$ (última fase de metamorfismo deste grupo) e 450-500 Ma (fase principal do vulcanismo riolítico do Paraná e estados do Sul). Pelo fato de os depósitos apresentarem-se dobrados em amplos anticlinais e sinformais, Muratori et al. (1967) correlacionaram a "Formação Camarinha" com a Formação Maricá (Bacia do Camaquã, Rio Grande do Sul), não descartando eventuais correlações com os grupos Castro e Guaratubinha, a norte e sudeste, respectivamente, da Bacia Camarinha, em que pese o vulcanismo ácido intercalado aos depósitos destas últimas estar ausente na Camarinha, sequer enquanto clastos. Esses autores identificaram ali uma deposição em ambientes subaquosos, com transporte pouco efetivo, evidenciado pela imaturidade textural e mineralógica dos depósitos, oriundos de áreas-fonte emersas tectonicamente ativas, que se deslocaram na forma de fluxos densos gravitacionais (mudflows) até um meio subaquático, onde adquiriram caráter de correntes de turbidez. Não descartaram também a hipótese de variações climáticas, em condições semiáridas, que afetariam o regime hidrológico, controlando as sucessões de conglomerados imaturos alternados a psamitos e pelitos (Muratori et al. 1967).

O embasamento aflorante na região de entorno da Bacia de Camarinha é constituído principalmente por metassedimentos do Grupo Açungui (Marini et al. 1967) intercalados por mármores dolomíticos e calcíticos e intrudidos por granitos do batólito de Três Córregos e, 


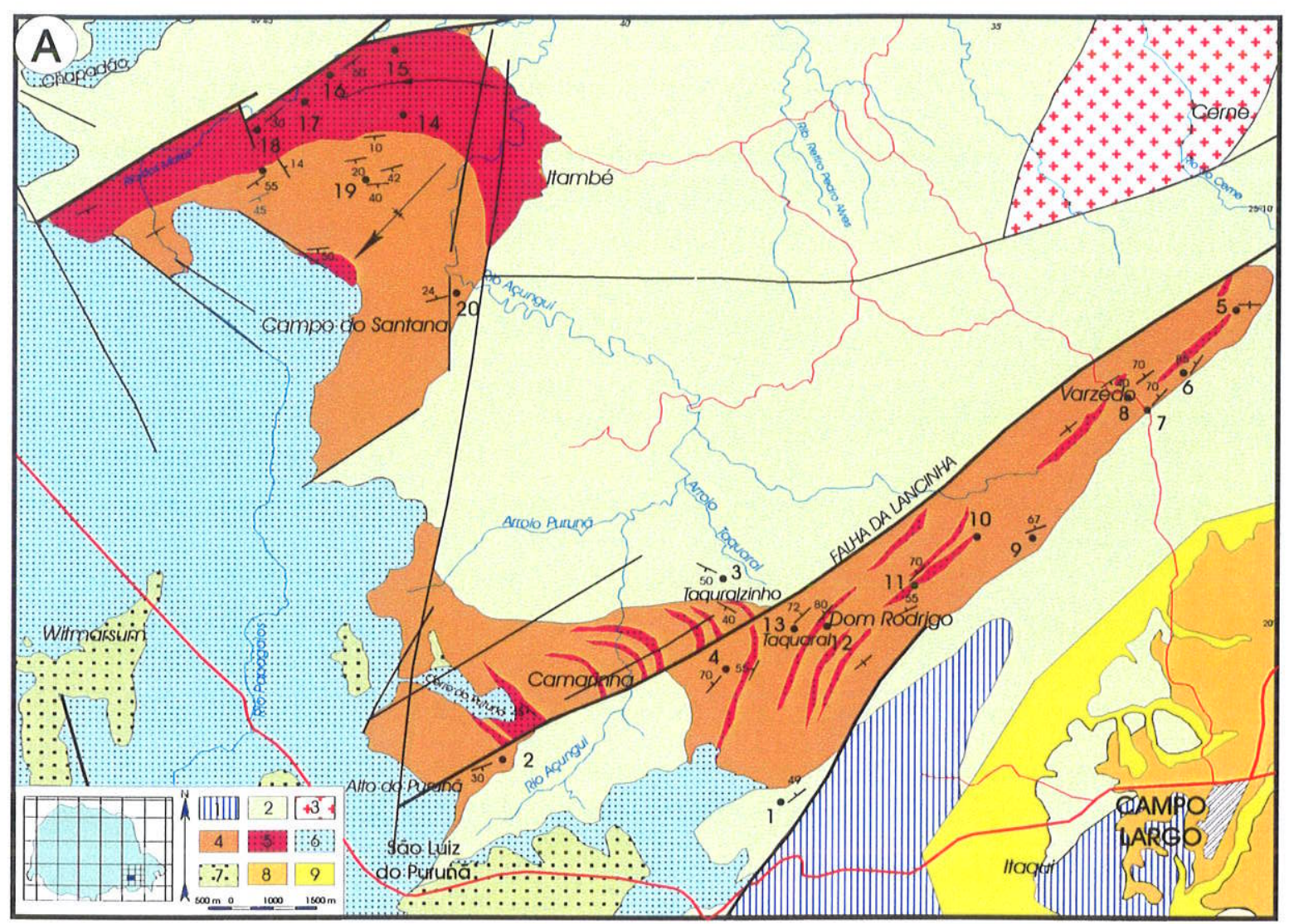

UNIDADES LITOLÓGICAS- Embasamento: 1. Gnaisses e migmatitos, 2. Metassedimentos do Grupo Açungui e 3. Granito do Cerne. Bacia Camarinha: 4. Siltitos e Arenitos e 5. Conglomerados. Bacia do Paraná e coberturas cenozóicas: 6. Formação Furnas, 7. Subgrupo Itararé, 8. Formação Gubirotuba e 9. Aluviōes.

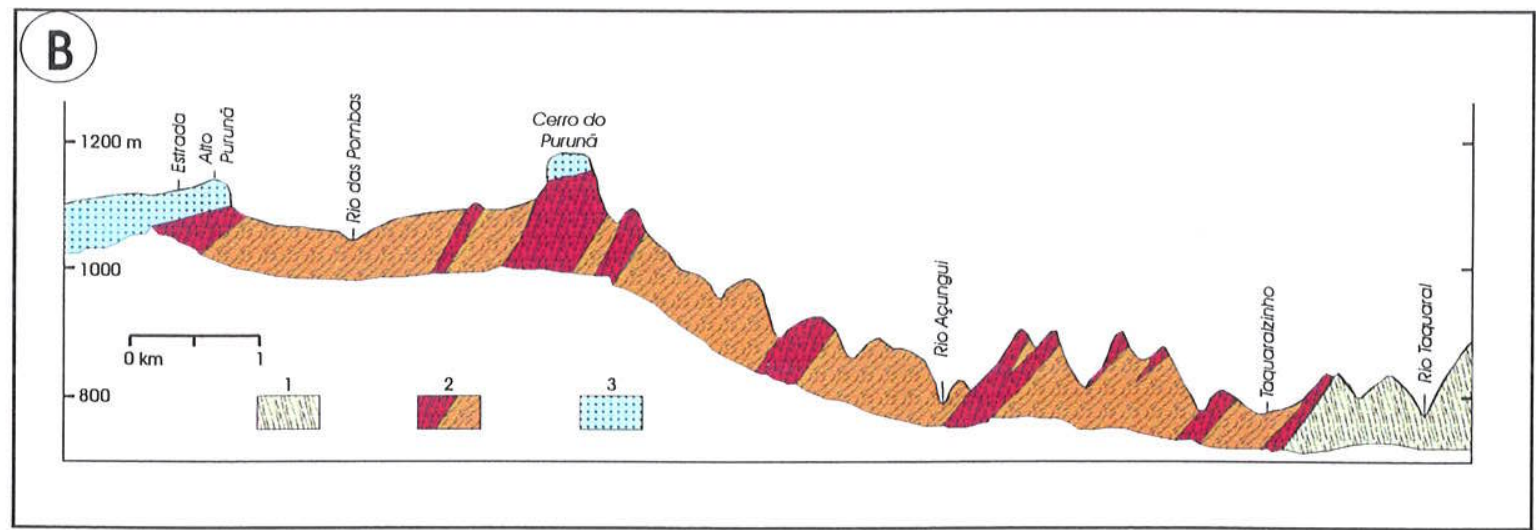

UNIDADES LITOLÓGICAS: 1. filitos do Grupo Açungui, 2. siltitos e conglomerados da Bacia Camarinha, e 3. Arenito Furnas.

Figura 4.7.1 - Esboço geológico da Bacia de Camarinha e seção geológica esquemática entre o Alto do Purunã e Taquaralzinho (compilado e modificado de Muratori et al. 1967). 
subsidiariamente, pelo Granito do Cerne. Ao sul, os metassedimentos do Grupo Açungui limitam-se com rochas migmatíticas paleo a mesoproterozóicas. E, ao norte, com rochas granitóides (granitos Três Córregos), migmatíticas paleo a mesoproterozóicas e efusivas ácidas com terrígenos intercalados do Grupo Castro. $\mathrm{O}$ embasamento mais antigo tem estruturação muito complexa, que reflete a ocorrência de sucessivos eventos tectônicos e metamórficos. Menor complexidade reservam os metassedimentos do Grupo Açungui, nos quais as estruturas reliquiares, em sua maioria, encontram-se intactas. Apesar do grau metamórfico baixo a muito baixo desses metassedimentos, a tectônica deformadora, adicionada do magmatismo poligenético e polifásico, tornou ainda mais complexo o empilhamento original.

Entretanto, característica marcante regionalmente, assim como de toda a Região Sudeste, é a estruturação geral dos terrenos em grandes dobramentos e falhas, com seus eixos e planos, respectivamente, condicionados ao trend $\mathrm{NE}-\mathrm{SW}$, que também exerceu aqui grande influência sobre a conformação e distribuição dos depósitos da Bacia de Camarinha e, posteriormente, sobre o próprio estilo de sua deformação.

Soares (1987) ao analisar a tectônica deformadora das seqüências tectono-sedimentares do centro-oeste do Escudo Paranaense, com enfoque sobre as seqüências do Grupo Açungui, Camarinha, Antinha e Castro, considerou que a raridade de topos invertidos nestas unidades induz supor que a tectônica controladora do empilhamento foi o "cavalgamento sem o desenvolvimento de grandes napes ou de dobramento isoclinal prévio". Para a Bacia Camarinha, Soares (1987) propôs origem relacionada com a sobrecarga litosférica provocada pelo empilhamento tectônico das seqüências do Grupo Açungui, com transporte tectônico para SE. Na região de retro-arco, a calha subsidente permitiu o preenchimento de bacia do tipo foreland, onde se instalaram leques aluviais e deltaicos, transicionais a ambientes marinhos, com transporte para oeste. A tectônica compressiva transcorrente, segundo o autor, foi deformadora (pós-preenchimento) e não geradora da bacia.

Popp (1972) inferiu como áreas-fonte da Bacia Camarinha as seqüências do Grupo Açungui provavelmente situadas a nordeste, baseando-se no conteúdo litoclástico e em paleocorrentes de marcas onduladas e estratificações cruzadas.

Moritz Junior \& Fiori (1987) realizaram estudos de deformação de seixos em metaconglomerados da Bacia de Camarinha contíguos à Falha da Lancinha. Os autores concluíram que o deslocamento lateral esquerdo (sinistrogiro) da falha foi responsável por rejeito da ordem de $950 \mathrm{~m}$, cumulativo desde o Cambro-Ordoviciano (suposta idade da sedimentação) 
até o Mesozóico, quando afetou também diques de diabásios associados ao vulcanismo Serra Geral.

No estudo aqui desenvolvido foi observado um total de 20 pontos de descrição de afloramentos, incluindo perfis contínuos em leitos e cortes de estradas que, localmente, alcançavam até os 300 metros de extensão. Os pontos visitados e analisados encontram-se discriminados na Figura 4.7.1A, compilada e modificada de Muratori et al. (1967). Nesta figura foram acrescentados, além da localização e número dos pontos visitados, apenas as atitudes do acamamento reliquiar $\left(\mathrm{S}_{0}\right)$. As demais estruturas, como falhas e eixos sinformais, e os contatos geológicos/litológicos foram mantidos tal como constam do desenho original dos autores, atendendo limitações do projeto, que objetivou o reconhecimento dos depósitos ali aflorantes, para efeito de comparações e correlações com aqueles situados em São Paulo e Minas Gerais.

No remanescente sul da Bacia Camarinha, região de Purunã, predominam atitudes de $\mathrm{S}_{0}$ com direção NE-SW e mergulho médio ao redor de $65^{\circ}$ para NW. Exceções foram verificadas no extremo sudoeste deste corpo (ponto CA-02) e na região de Taquaralzinho (CA-03). No ponto CA-02, o acamamento tem direção NE-SW e mergulho de $30^{\circ}$ para SE. No ponto CA-03, situado a noroeste da Falha da Lancinha, $\mathrm{S}_{0}$ tem direção NW-SE e mergulho de $50^{\circ}$ para $\mathrm{SW}$. Neste mesmo corpo, outra exceção ocorre em seu extremo nordeste (ponto CA-05), no qual $\mathrm{S}_{0}$ assume direção aproximada E-W com mergulho subvertical. E, também, no ponto CA-08, onde $\mathrm{S}_{0}$ mantém direção NE-SW, mas mergulha para SE com $70^{\circ}$.

No remanescente noroeste da bacia, região entre Campo do Santana e do Rio dos Motas, no flanco noroeste de suposta estrutura sinformal proposta por Muratori et al. (1967), predominam atitudes de $\mathrm{S}_{0}$ com direção NE-SW e com mergulhos variáveis entre $60^{\circ}$ e $40^{\circ}$ para sudeste e, em apenas um local observado (ponto CA-20), já no flanco sul dessa estrutura, $S_{0}$ tem direção NE-SW com mergulho de $24^{\circ}$ para NW. E, excepcionalmente, a sudeste do ponto CA$18, \mathrm{~S}_{0}$ assume direção NW-SE com mergulho de $14^{\circ}$ para NE.

No corpo remanescente sul da bacia, e a sul da Falha da Lancinha, as atitudes de $\mathrm{S}_{0}$ parecem se aproximar mais daquelas originais, em que apenas pequenas rotações ocorreram segundo o eixo horizontal, conformando sinformas e antiformas suaves com eixos direcionados segundo NE-SW. Neste mesmo corpo, mas a norte da Lancinha, as rotações ocorreram segundo eixo vertical também, colocando $\mathrm{S}_{0}$ com mergulhos para $\mathrm{SW}$ e, talvez, SE. No corpo ao norte, entre Campo de Santana e Rio dos Motas, as rotações ocorreram segundo eixo horizontal e vertical, como se depreende de dobramento proposto por Muratori et al. (1967), conferindo à 
estrutura sinformal caimento de seu eixo para SW, guardando tal estruturação concordância estrutural com o embasamento e proximidade com as posições originais da deposição.

A sul da Falha da Lancinha encontram-se depósitos predominantemente subaquosos areno-silto-argilosos sucedidos por outros conglomeráticos, provenientes de regiões emersas subaéreas, onde possivelmente desenvolveram-se leques aluviais. Os ambientes subaquosos estariam representados por águas rasas marinhas, acima do nível de base de ondas normais e sujeitos ao retrabalhamento por ondas de tempestades ocasionais, como pode ser visto no ponto CA-01, extremo norte do referido corpo, em corte da rodovia BR-277.

Nesse ponto (CA-01) ocorre o predomínio de fácies marinhas rasas, esporadicamente intercaladas por conglomerados polimíticos clasto-sustentados. As fácies marinhas são constituídas por uma sucessão de seqüências com espessuras de $30-50 \mathrm{~cm}$ que têm na base delgado nível conglomerático rico em intraclastos silto-argilosos, placóides e angulosos, com tamanho médio de $10 \mathrm{~cm}$, envoltos por matriz arenosa mal selecionada. Para o topo predominam arenitos mal selecionados conglomeráticos (seixos e grânulos) com estratificação cruzada planar a acanalada de pequeno porte, com distribuição de seixos de extraclastos (de granitóides e metassedimentos) e intraclastos (silto-argilosos) ao longo das lâminas frontais e na base destas (Figura 4.7.2). Este nível pode alcançar espessuras de até $30 \mathrm{~cm}$. Para o topo, gradacionam abruptamente ou são cortados por arenitos finos a muito finos, marrom a bege, com estratificações cruzadas acanaladas de pequeno porte, cuja espessura pode atingir até os $20 \mathrm{~cm}$. Estes gradacionam a siltitos argilosos com arenitos muito finos, marrom escuros, com marcas onduladas assimétricas de cristas retilíneas a lingüiformes (Figura 4.7.3), que mostram terem sido retrabalhadas por interferências de outras ondas. Os fluxos, tanto nas cristas assimétricas quanto nos arenitos com estratificações cruzadas de pequeno porte, dirigem-se para NW. Localmente, no topo da seqüência anterior, estruturações dômicas com diâmetro de $1,10 \mathrm{~m}$ e amplitude de $10 \mathrm{~cm}$ sugere a participação de ondas de tempestades. A estruturação ocorre sobre arenitos médios a finos laminados e com ondulações suaves, às quais se associam estruturação em domo. O topo da estruturação é recoberto por arenitos finos com marcas onduladas aparentemente ssimétricas $(\lambda=10 \mathrm{~cm}$ e $A=1,5 \mathrm{~cm})$ ou com fluxos para NW. Esporadicamente, leitos conglomeráticos com espessuras entre 10 a $40 \mathrm{~cm}$ podem se intercalar entre pacotes métricos $(5-10 \mathrm{~m})$ da seqüência anterior. Esses conglomerados são polimíticos finos a grossos com intraclastos de siltito argiloso marrom escuro na base e com gradações normais a arenitos médios a finos com ondulações assimétricas, no topo. 
Figura 4.7.2 - Metarenitos conglomeráticos com estratificação cruzada de pequeno porte (fluxo da esquerda para a direita - NW). Ao longo dos foresets orientam-se seixos de granitóides e de metassedimentos, além de intraclastos de siltitos argilosos marrom escuros. Ponto CA-01.

Figura 4.7.3 - Marcas onduladas assimétricas com cristas sub-retilíneas a sub-lingüiformes geradas por processos de interferência de ondas, desenvolvidos sobre arenitos muito finos silto-argilosos. Fluxo do alto (à esquerda) para baixo (à direita) da foto (NW). Ponto CA-01.

Figura 4.7.4 - Matriz de conglomerado polimítico da Bacia de Camarinha predominantemente arenosa e mal selecionada, com grânulos intraclásticos de siltitos cimentados por óxidos/hidróxidos de Fe e extaclastos de quartzitos finos (extremo superior central da foto), de metassiltitos (canto esquerdo inferior) e de calcarenitos (canto direito inferior). Os grãos de quartzo apresentam-se fraturados e com extinção ondulante. Em geral, os grãos da matriz e os grânulos do arcabouço apresentam bom arredondamento. Nicóis cruzados. Amostra do ponto CA07.

Figura 4.7.5 - Intercalação de arenitos mal selecionados e siltitos argilosos com estratificação cruzada planar de pequeno porte (fluxo para a esquerda da foto - NE) em conglomerados finos polimíticos clasto-sustentados. Na base dos arenitos (à direita da foto), ocorre nível conglomerático com intraclasto arredondado de siltito argiloso marrom escuro, que se destaca, e seixos e grânulos de granitóides, K-feldspatos e metassedimentos. Nos conglomerados finos, abaixo da intercalação arenosa ocorre gradação normal (topo para o alto). Ponto CA-06. 

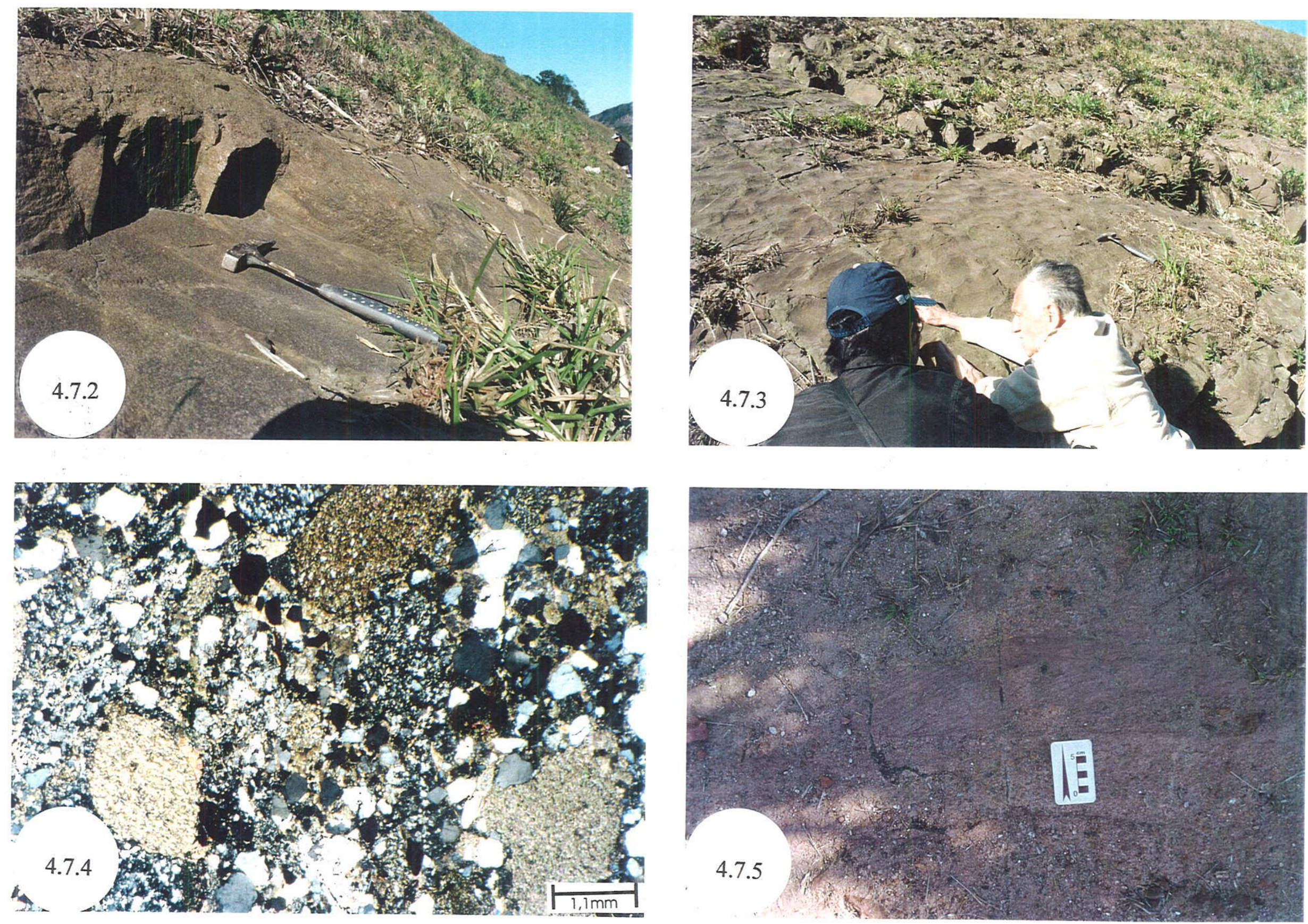
Avançando-se para noroeste, os fluxos conglomeráticos tornam-se mais freqüentes e espessos, mas ainda assim não predominam sobre os termos pelito-psamíticos marinhos, significando que houve uma progradação da cortina aluvial até as regiões mais distais da antepraia, graças à variação do aporte de detritos da área-fonte e/ou às pulsações do nível do mar.

Os conglomerados são polimíticos clasto-sustentados, com arcabouço bi-modal apresentando de um lado matacões, calhaus e seixos e, de outro, seixos e grânulos de rochas granitóides, metacalcarenitos, metassiltitos, calciossilicáticas, filitos e intraclastos silto-argilosos marrom avermelhados, além de intraclastos de conglomerados. Os clastos são subangulosos a subarredondados e os intraclastos pelíticos são, em geral, placóides angulosos. A matriz é arenosa lítica, feldspática a arcoseana, totalmente impregnada (cimento) por óxidos/hidróxidos de ferro, que confere à rocha coloração marrom arroxeada a avermelhada. Podem variar os teores de clastos de granitóides. Nas porções mais a noroeste predominam conglomerados ricos em clastos de granitóides, enquanto nas porções intermediárias do corpo predominam conglomerados pobres nestes clastos, mas ricos em intraclastos silto-argilosos a arenosos e extraclastos de metassedimentos do Grupo Açungui (Figura 4.7.4). Essa última modalidade marcaria evento regressivo acompanhado da expansão da planície aluvial, onde processos de ressedimentação ocorreriam ("planície/rampa de lavagem"), cujos produtos seriam incorporados aos fluxos densos gravitacionais das porções finais (distais) de leques aluviais e despejados finalmente em corpo d'água marinho. Os conglomerados organizam-se em estratos de 0,2 a 1,0 $m$ de espessura, podendo configurar pacotes com várias dezenas de metros de espessura, ou apenas de alguns decímetros, isolados e intercalados entre termos pelito-psamíticos. Predominam blocos e calhaus na base que gradacionam ao topo para conglomerados finos, com seixos e grânulos, não raro transicionais a arenitos mal selecionados ou sucedidos erosivamente por estes. Os arenitos mal selecionados, às vezes, exibem estratificações cruzadas de pequeno porte, ou são aparentemente maciços ou com estratificação plano-horizontal (Figura 4.7.5). Os clastos nos conglomerados podem exibir franca imbricação (Figura 4.7.6), mas na maioria dos casos apenas isorientação de clastos ao longo do leito foram verificadas.

As seqüências pelito-psamíticas destacam-se pela ritmicidade de camadas e lâminas constituídas de arenitos finos a muito finos siltosos com gradação normal para siltitos argilosos e argilitos. As estruturas presentes e abundantes são a laminação/estratificação plano-paralela, ondulações assimétricas, truncamentos entre lâminas, estruturas de sobrecarga com convoluções (slumps), estruturas de escape de fluídos (dish) e estruturas flaser e linsen. As marcas onduladas 
Figura 4.7.6 - Metaconglomerado polimítico clasto-sustentado com sucessivos "tapetes" com gradação normal, nos quais se destacam a imbricação de clastos, indicativa de fluxos da esquerda para a direita da foto (SW), e calhaus de rochas metabasíticas e de calciossilicatadas (esbranquiçadas), angulosos a subangulosos. Ponto CA-02.

Figura 4.7.7 - Ritmitos areno-silto-argilosos com intercalações delgadas de arenitos conglomeráticos, nas quais se destacam grânulos e seixos de K-feldspatos esbranquiçados. Nos ritmitos ocorrem marcas onduladas assimétricas (com fluxo da esquerda para a direita da foto), lentes de arenitos mal selecionados cinza-escuro, ricos em opacos, e estruturas relacionadas à sobrecarga, como convoluções (slumps) e escape de fluídos (dish), à esquerda da foto, acima da escala. Nas intercalações conglomeráticas observa-se, localmente, abaixo da ponta da escala (martelo) e à esquerda, estratificação cruzada de pequeno porte com clastos de K-feldspatos ao longo das lâminas frontais, indicando fluxo da direita para a esquerda. Ponto CA-11.

Figura 4.7.8 - Extremo noroeste da bacia, na região do Rio dos Motas. Ao fundo, escarpamento formado pelos arenitos e conglomerados da Formação Furnas que repousam, erosivamente, sobre os depósitos da Bacia de Camarinha. Tomada obtida próxima do ponto CA-14, com visada para NE.

Figura 4.7.9 - Conglomerado polimítico fino clasto-sustentado no qual predominam clastos (seixos e calhaus) angulosos a subangulosos de metassedimentos do Grupo Açungui e intraclastos marrom escuros, silto-argilosos, sobre clastos arredondados de granitóides, que se destacam à esquerda da foto, acima da escala graduada. Ponto CA- 17. 

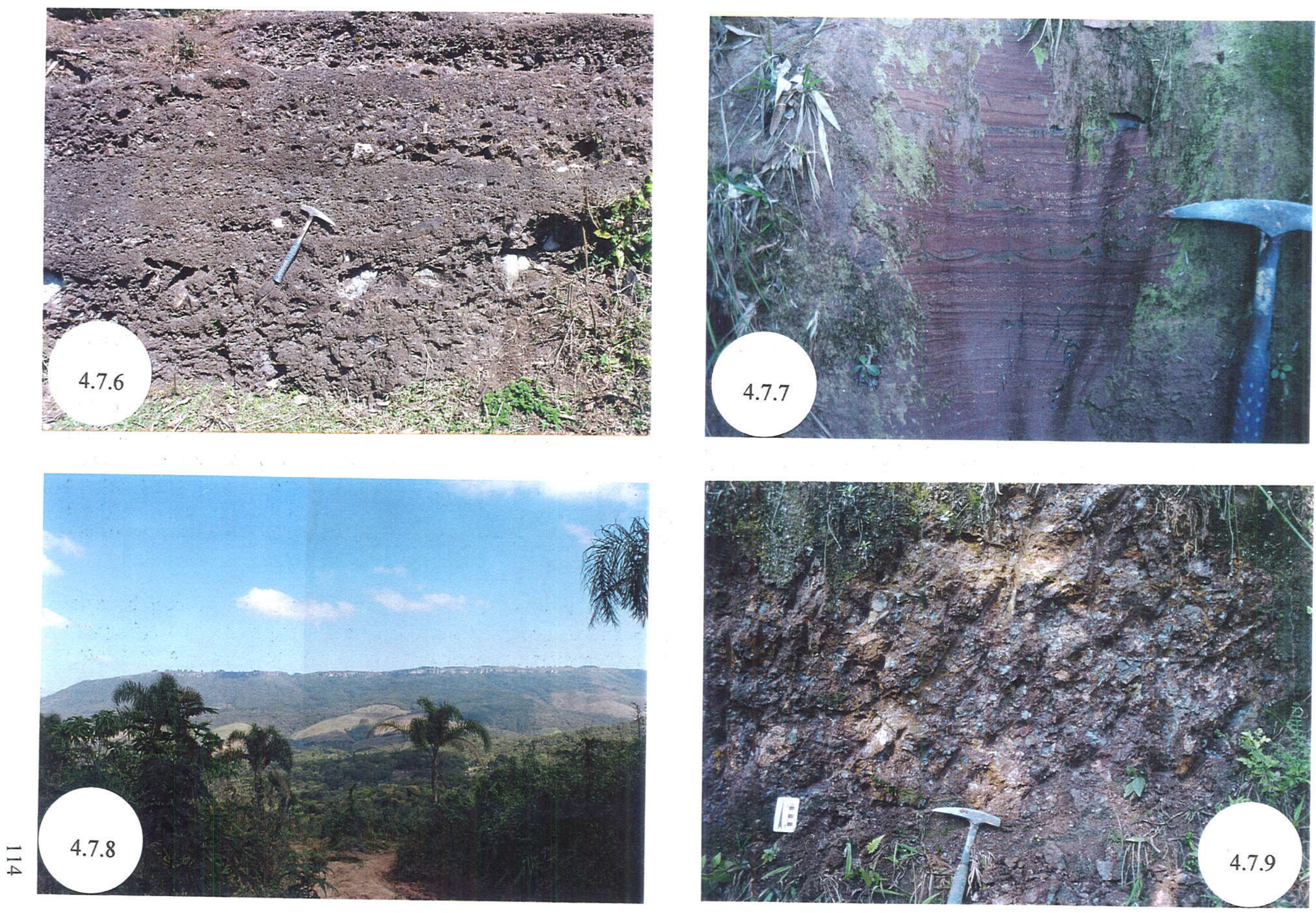
assimétricas indicam, em geral, fluxos predominantemente para NE, com sugestivas inversões de fluxos para SW. As intercalações psamo-psefíticas ocorrem sob a forma de leitos de conglomerados polimíticos finos clasto-sustentados que interceptam erosivamente, com base plana a pouco irregular, uma seqüência de ritmitos. Suas espessuras variam de alguns centímetros até poucos metros e as transições de uma espessura a outra ocorre de modo gradativo (thickening ou thinning -upward), tanto em direção ao topo (NW) quanto em direção à base (SE) das seqüências. De outro modo, os termos psamo-psefíticos podem ocorrer incorporados ou intercalados aos ritmitos como lentes delgadas constituídas de areias, grânulos e pequenos seixos de feldspatos (em destaque na Figura 4.7.7), com gradação normal e com estratificações cruzadas de pequeno porte e fluxo divergente das ondulações assimétricas dos ritmitos. Localmente, podem ocorrer concentrações arenosas, com grânulos, ricas em minerais opacos (pesados) de cor cinza-escuro. Nos ritmitos, as cores são em geral marrom arroxeadas, predominando nos níveis siltosos o marrom arroxeado claro e nos argilosos, o marrom arroxeado escuro. Nas areias finas a cor predominante é o marrom claro pouco arroxeado.

A noroeste da Falha da Lancinha, ainda no corpo sul da bacia, as observações restringiram-se a um único ponto (CA-03), onde ocorre intercalação rítmica de conglomerados clasto-sustentados e arenitos médios a finos com laminação plano-paralela, cujas espessuras variam de alguns centímetros a decímetros e os contatos são bruscos entre um termo e outro. Este ponto situa-se na base da seqüência, uma vez que $\mathrm{S}_{0}$ tem mergulhos para $\mathrm{SW}$, no mesmo sentido da polaridade estratigráfica. Esta seqüência constitui perfil típico (Figura 4.7.1B) descrito por Muratori et al. (1967), entre o Alto do Purunã e Taquaralzinho, onde está localizado o ponto CA-03. Como pode ser visto na figura, ocorre uma sucessão de ritmitos com conglomerados da base para o topo, muito semelhante ao descrito para a seqüência ao sul da Falha da Lancinha. Os depósitos do ponto CA-03 poderiam ser representativos de ambiente litorâneo, dada a tabularidade das camadas arenosas com laminação interna e ao caráter também tabular dos conglomerados clasto-sustentados; tal feição espelharia associação de fácies praiais (areias) com fácies distais de leques aluviais (conglomerados) em processos de afogamento em corpo d'água. Entretanto, a alteração imtempérica e as exposições restritas não permitiram maiores conclusões.

No corpo sinformal a noroeste da bacia, na região de Campo do Santana, predominam conglomerados polimíticos clasto-sustentados na sua porção noroeste, sobrepostos com discordância erosiva pela base da Formação Furnas, que na região desenvolve magnífico escarpamento (Figura 4.7.8). Os conglomerados clasto-sustentados têm arcabouço constituído por calhaus, e até matacões, seixos e grânulos de rochas granitóides, metassedimentos terrígenos 
e carbonáticos do Grupo Açungui, além de clastos de quartzitos, rochas calciossilicáticas e metabásicas e intraclastos de siltitos marrom escuro. A matriz é lítica, feldspática a arcoseana cimentada por óxidos/hidróxidos de Fe, conferindo cor marrom escura arroxeada predominante ao pacote. Os clastos, em geral, são subangulosos a subarredondados (Figura 4.7.9) mas, localmente (ponto CA-15), arredondamento e esfericidade são bem desenvolvidos, notadamente sobre clastos de quartzitos róseos (Figura 4.7.10). As camadas representativas dos fluxos densos (traction carpets) podem variar de poucos centímetros a 1 metro de espessura, predominando espessuras centimétricas. Nestas, a gradação normal é comum, onde conglomerado fino (grânulo e areias) ocupa o topo da seqüência. Às vezes, aparentam não ter qualquer estruturação, principalmente quando a camada é mais espessa. Localmente (ponto CA-16) pacotes de siltitos argilosos marrom avermelhados laminados e com intercalações arenosas podem ocorrer, mas suas relações com os conglomerados não ficaram claras, graças à descontinuidade da exposição.

Para sul, ponto CA-18, ocorrem arenitos finos a médios arcoseanos e micáceos (cristais sub a milimétricos de sericita/muscovita), laminados (lâminas com $0,5 \mathrm{~cm}$ em média), marrom arroxeados a bege, com grãos angulosos de quartzo e feldspatos, intercalados por níveis mais argilosos delgados (Figura 4.7.11). Predomina nesta seqüência a tabularidade dos estratos planoparalelos, localmente perturbada por estruturas de convolução (Figura 4.7.12). Mais a sul ainda (ponto CA-19), em cachoeira do Rio da Prata, ocorrem arenitos de granulação média a fina, com tênues níveis de arenitos mal selecionados na base de seqüência gradacional normal com 0,5 a 2 $\mathrm{cm}$ de espessura. Os arenitos apresentam-se em estratos tabulares onde ocorre bandamento/laminação plano-horizontal ao lado de marcas onduladas assimétricas $(\lambda=5-10 \mathrm{~cm}$ e $A=1-2 \mathrm{~cm}$ ) com fluxos direcionados para $\mathrm{SW}$. A algumas centenas de metros a $\mathrm{SW}$, ao longo da drenagem, Ciguel et al. (1992) identificaram as icnoespécies Gordia arcuata Ksiazkiewicz, Planolites montanus Richter e o icnogênero Skolithos Haldemann, preservados em epirrelevos, além de identificarem traços de repouso de organismos medusóides, provavelmente cnidários. Os autores, conseqüentemente, concluíram que a deposição processou-se em ambiente marinho, e não continental como advogado por alguns autores (e.g. Popp 1972), entre o Vendiano e o Tomotiano.

Ante o exposto, pode-se concluir que a Bacia de Camarinha tem preservadas fácies ou associações de fácies representativas de depósitos subaéreos, mais propriamente de leques aluviais, que transitavam diretamente sobre corpo aquoso marinho raso, região de antepraia, sempre acima do nível das ondas normais. Ocasionalmente, estes depósitos foram retrabalhados por ondas de tempestades, com fluxos dirigidos para NW, no mesmo sentido das correntes de 
Figura 4.7.10 - Conglomerado polimítico fino, com destaque para o arredondamento dos clastos, em especial para os de quartzitos róseos, à direita da foto. A escala assentase sobre estrato delgado com granulação mais fina e que separa estratos, superior e inferior, sem qualquer estruturação aparente. Ponto CA-15.

Figura 4.7.11 - Arenitos médios a finos com estratificação plano-horizontal, laminados, marrom arroxeados a bege com intercalações de estratos argilosos com estratificação plano-horizontal a cruzada de baixo ângulo e com estruturas de convolução. Ocorrem, também, estratos centimétricos ricos em opacos, marrom escuro acinzentados (porção centro-inferior da foto) e estruturas do tipo "chama" (sobrecarga), como pode ser visto na porção inferior da foto, onde pacote de arenitos dispõem-se sobre arenitos argilosos, aparentemente maciços. Ponto CA-18.

Figura 4.7.12 - Os mesmos arenitos da figura anterior, com destaque para as estruturas de convolução (slumps), na porção esquerda inferior da foto (acima da escala), e para os estratos delgados intercalados, ricos em opacos. Ponto CA-18. 

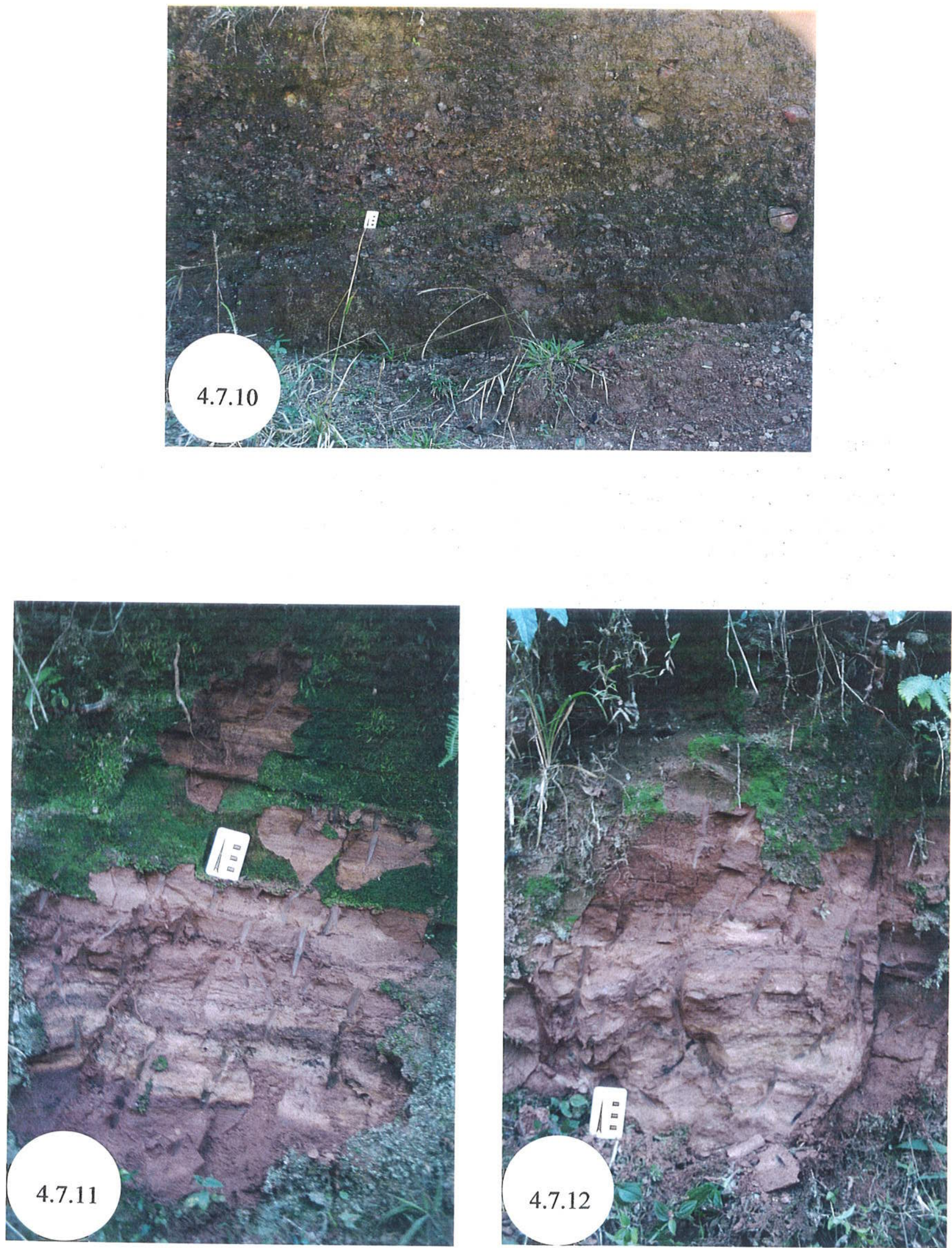
ondas normais. Pelo menos em um intervalo de tempo, como visto na porção intermediária do corpo situado a sul da Falha da Lancinha, processos de ressedimentação foram intensos, provavelmente associados a evento transgressivo marinho.

Considerando-se que os pacotes estejam próximos de suas posições originais (excetua-se a seqüência do corpo sul a norte da Falha da Lancinha) e apenas adernados/dobrados suavemente, mas em concordância estrutural com o embasamento, a linha de costa pretérita estaria direcionada segundo ao que hoje é NE-SW. O continente estender-se-ia para noroeste desta linha e as águas rasas marinhas, para sudeste. Desse modo, variações de fluxos em pelitos para SW e NE, poderiam ser explicadas pela ocorrência inerente de correntes litorâneas secundárias. 


\section{ASPECTOS GEOQUÍMICOS}

Foram realizadas nos depósitos de algumas das bacias em estudo um total de 30 análises litogeoquímicas, nas quais foram considerados os elementos maiores e traços. Para essas análises foram selecionadas: 7 amóstras de seixos de riólitos de metaconglomerado da ocorrência isolada I4 (ponto ET-54), 9 amostras de laminitos silto-argilo-arenosos com cinzas vulcânicas intercaladas (ponto ET-50) e 1 amostra de metassiltito-argilo-arenoso intercalado em metaconglomerado (ponto ET-64), da Bacia Eleutério; 5 amostras de mármores calcíticos e dolomíticos e 1 de metargilito arenoso da Bacia Cajamar; 2 amostras de mármore calcítico e dolomítico do Subgrupo Açungui; 3 amostras de metarenitos e metassiltitos arenosos da Bacia Camarinha; e 1 amostra de metassiltito calcífero da Bacia Pouso Alegre. Os resultados analíticos obtidos encontram-se disponíveis nas Tabelas 1 e 2, do Anexo 1.

Foi gerado o diagrama de Harker de maneira a permitir um diagnóstico fácil da variação em abundância dos elementos maiores das distintas rochas, utilizando-se $\mathrm{SiO}_{2}$ como índice de comparação (Figura 5.1) Uma primeira avaliação permitiu distinguir comportamentos díspares dos elementos com relação à natureza das rochas. Nesse sentido, os riólitos, os metassedimentos e as cinzas vulcânicas mostram um comportamento linear positivo para $\mathrm{Na}_{2} \mathrm{O}, \mathrm{K}_{2} \mathrm{O}, \mathrm{MnO}$ e, em menor proporção, para $\mathrm{Al}_{2} \mathrm{O}_{3}$; entretanto, a concentração desses elementos, exceção feita para o $\mathrm{MnO}$, é pouco expressiva para os carbonatos. Uma variação mais relevante, para esta última litologia, é verificada junto aos elementos de $\mathrm{CaO}$ e $\mathrm{MgO}$. A baixa concentração de $\mathrm{P}_{2} \mathrm{O}_{5}$ representa um comportamento generalizado para as diversas litologias.

Por outro lado, é importante assinalar que existe uma concentração maior de $\mathrm{Al}_{2} \mathrm{O}_{3}$ para as cinzas vulcânicas, $\mathrm{Na}_{2} \mathrm{O}$ para os metassedimentos, $\mathrm{K}_{2} \mathrm{O}$ para os riólitos e CaO, para os carbonatos, podendo isto significar fontes diferentes dos materiais ou, alternativamente, indicar também processos intempéricos e/ou diagenéticos que influíram na concentração desses elementos.

Para os elementos traços, optou-se também por representá-los no diagrama de Harker, utilizando-se o Zr como índice de variação (Figura 5.2). Esta comparação permite visualizar que os carbonatos, na sua maior parte, situam-se perto da origem, acusando extremo empobrecimento; por outro lado, os riólitos, os metassedimentos e as cinzas vulcânicas exibem comportamentos mais uniformes. Levando em consideração essa distribuição linear podemos notar que os riólitos e os metassedimentos guardam boas concordâncias para $\mathrm{Rb}, \mathrm{Cs}, \mathrm{Ba}, \mathrm{Sr}, \mathrm{Hf}$, $\mathrm{Nb}$, Th e Ta; enquanto que $\mathrm{Y}, \mathrm{Cr}, \mathrm{Ni}, \mathrm{V}, \mathrm{U}, \mathrm{Pb}$ e Ga mostram-se um tanto mais dispersos. No 

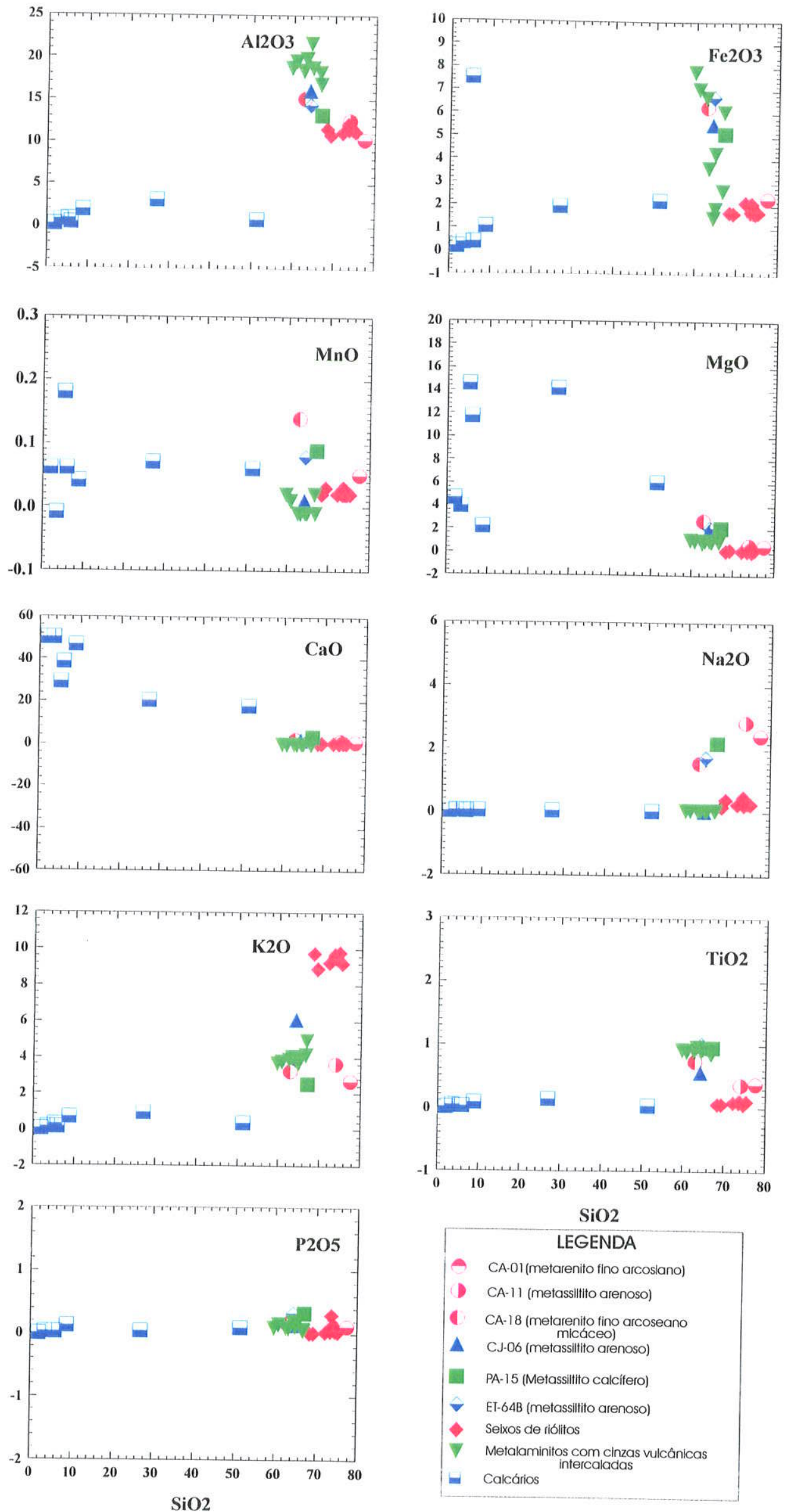

$\mathrm{SiO} 2$

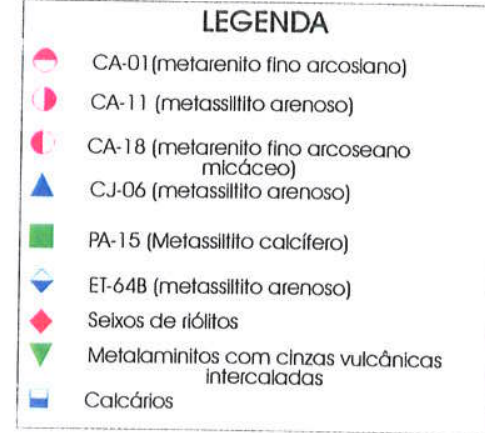

Figura 5.1 - Diagramas binários das relações $\mathrm{SiO}_{2}$ versus óxidos (em porcentagem em peso) em metassedimentos, seixos riolíticos e em cinzas vulcânicas. 

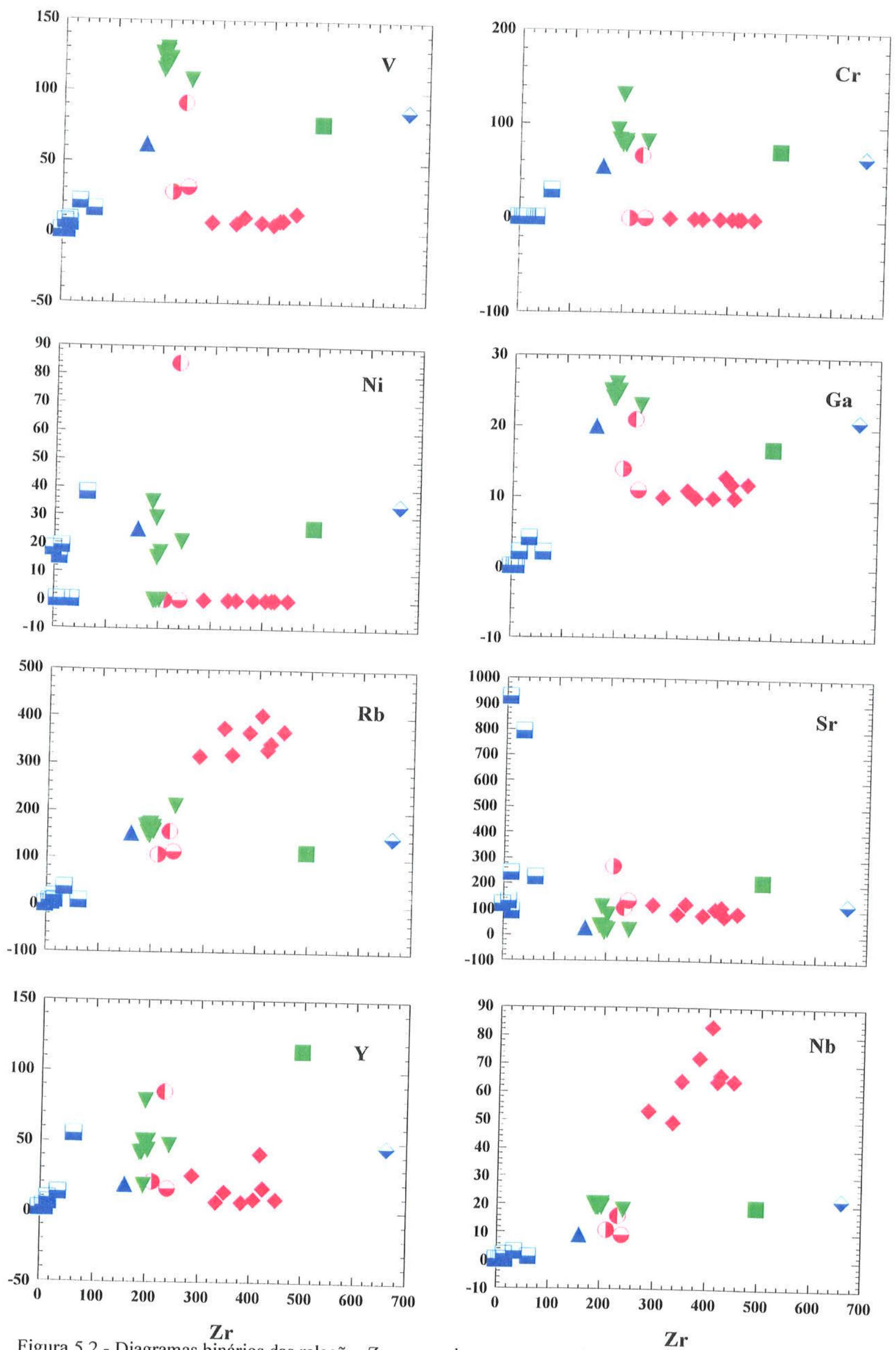

Figura 5.2 - Diagramas binários das relações Zr versus elementos traços (em ppm) de metassedimentos, seixos riolíticos
e de cinzas vulcânicas. Legenda igual a da figura anterior. 
Continuação da Figura 5.2
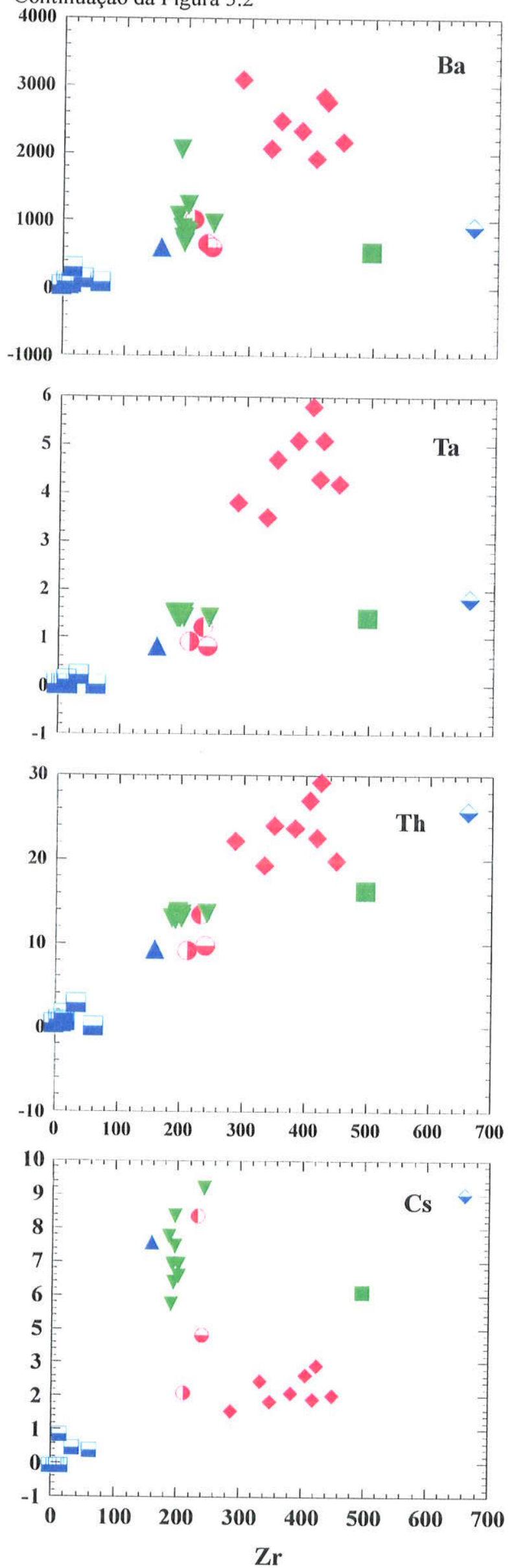
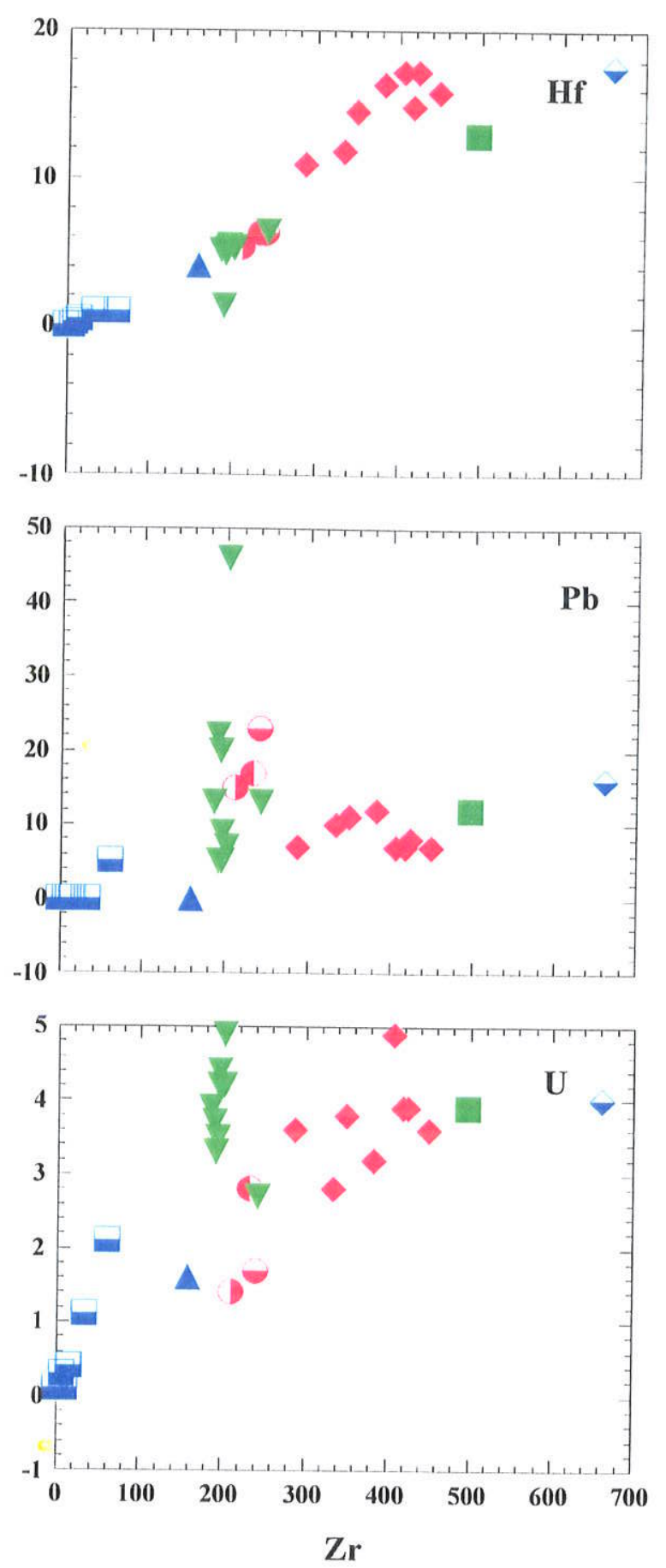
tocante às cinzas vulcânicas, é possível constatar a existência de uma maior dispersão no eixo vertical. Este comportamento muito provavelmente esteja refletindo grau de intemperismo avançado do material, permitindo apenas observar concordância para os elementos de $\mathrm{Rb}, \mathrm{Ba}, \mathrm{Sr}$ e Hf.

Quanto aos processos de alteração química desenvolvidos durante a sedimentação/diagênese e mesmo durante a exposição dessas rochas às condições intempéricas mais modernas, utilizou-se como parâmetro aquilatador do grau de alteração sofrido o índice CIA (Chemical Index of Alteration) de Nesbitt \& Young (1982), que considera as relações da alumina $\left(\mathrm{Al}_{2} \mathrm{O}_{3}\right)$ com os demais óxidos de $\mathrm{Ca}, \mathrm{Na}$ e $\mathrm{K}$, todos em proporções moleculares, na seguinte equação:

$$
\mathrm{CIA}=\left[\mathrm{Al}_{2} \mathrm{O}_{3} /\left(\mathrm{Al}_{2} \mathrm{O}_{3}+\mathrm{CaO}+\mathrm{Na}_{2} \mathrm{O}+\mathrm{K}_{2} \mathrm{O}\right)\right] \times 100 .
$$

As amostras de seixos de riólitos e de metassedimentos terrígenos apresentaram-se, respectivamente, sãs a pouco alteradas, com CIA para os riólitos ao redor de 50 e entre 50 e 62 , para os metassedimentos (Figura 5.3). Nas amostras de laminitos com cinzas vulcânicas, os valores de CIA ficaram entre 75 e 84, denotando sua maior alteração química, significando isto a somatória de processos de transformações mineralógicas ocorridas durante a sedimentação/diagênese/anquimetamorfismo com aqueles recorrentes, modernamente, na alteração intempérica. A Figura 5.3 mostra que há um enriquecimento contínuo de alumina nos metassedimentos e laminitos/cinzas vulcânicas, enquanto nos riólitos os valores desse óxido (em $\%$ wt) permanecem praticamente estacionários. Os metalaminitos/cinzas são superiormente enriquecidos em alumina quando comparados aos demais metassedimentos, entretanto, são relativamente mais empobrecidos em $\mathrm{CaO}$ e $\mathrm{Na}_{2} \mathrm{O}$, mas têm valores de $\mathrm{K}_{2} \mathrm{O}$ bastante similares aos destes últimos, evidenciando pouca mobilização deste óxido, apesar dos valores altos de CIA.

Harnois (1988), considerou que o $\mathrm{K}_{2} \mathrm{O}$ comporta-se como um componente imóvel à medida que $\mathrm{oK}^{+}$é reincorporado aos argilo-minerais neoformados na diagênese, enquanto $\mathrm{Na}^{+}$ $\mathrm{e} \mathrm{Ca}^{2++}$ não têm grande capacidade de serem retidos. Tais considerações levaram o autor a propor um novo índice de medida da alteração química de rochas, designado CIW (Chemical Index of Weathering), similar ao CIA de Nesbitt \& Young (1982), a não ser pela exclusão de $\mathrm{K}_{2} \mathrm{O}$ de sua fórmula. $\mathrm{E}$, conseqüentemente, com esse índice, devido à ausência da potassa, os riólitos assumem valores de CIW entre 89 e 97 (Figura 5.4), os metalaminitos valores superiores a 99 e os demais metassedimentos, predominantemente, entre 58 e 73. As referências de Harnois (1988) de CIW para granitos sãos ficam entre 57 e 63, enquanto que para os resíduos mais alterados 


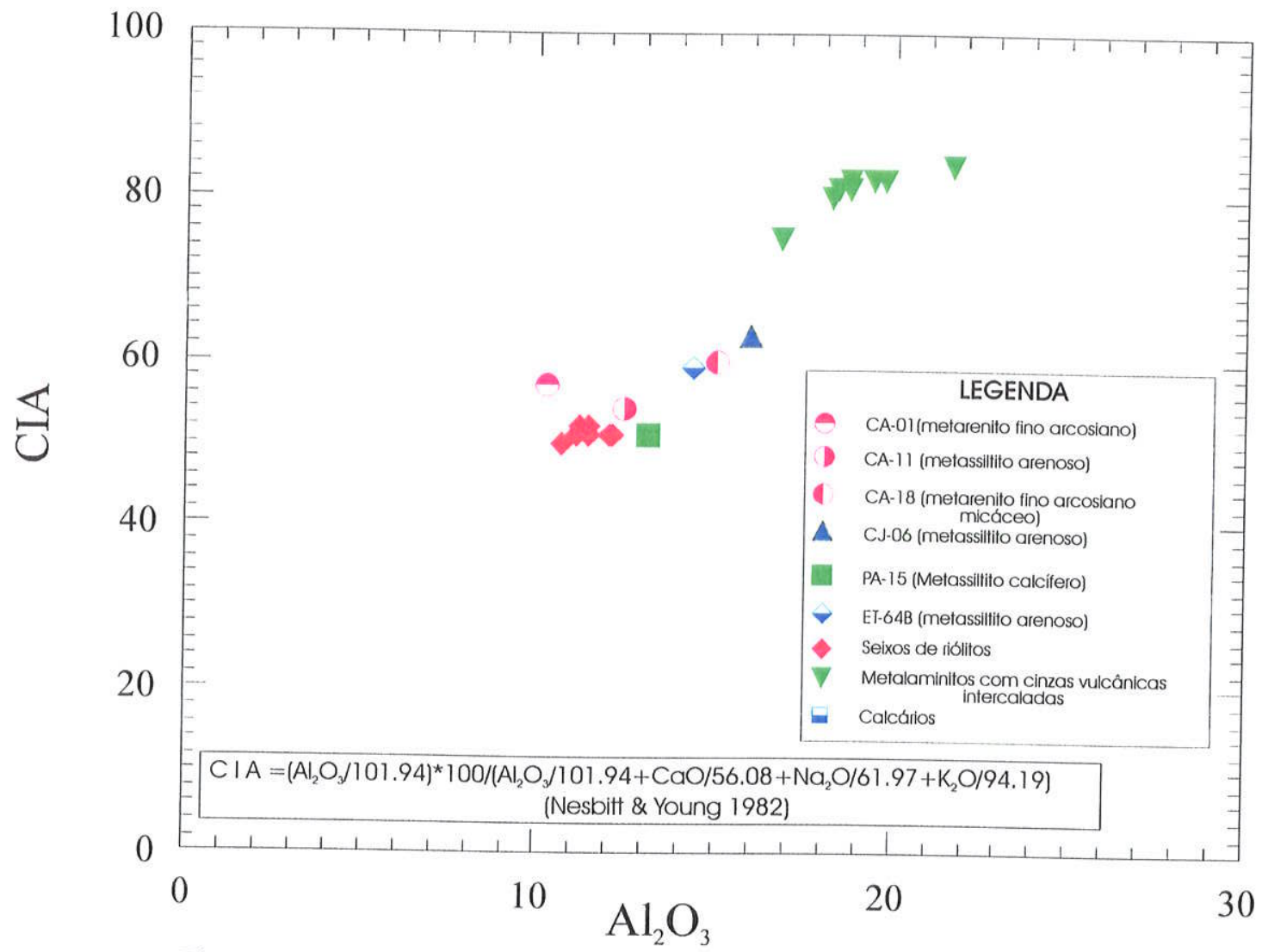

Figura 5.3 - Valores do índice de alteração química (CIA) das rochas analisadas versus $\mathrm{Al}_{2} \mathrm{O}_{3}(\% \mathrm{wt})$.

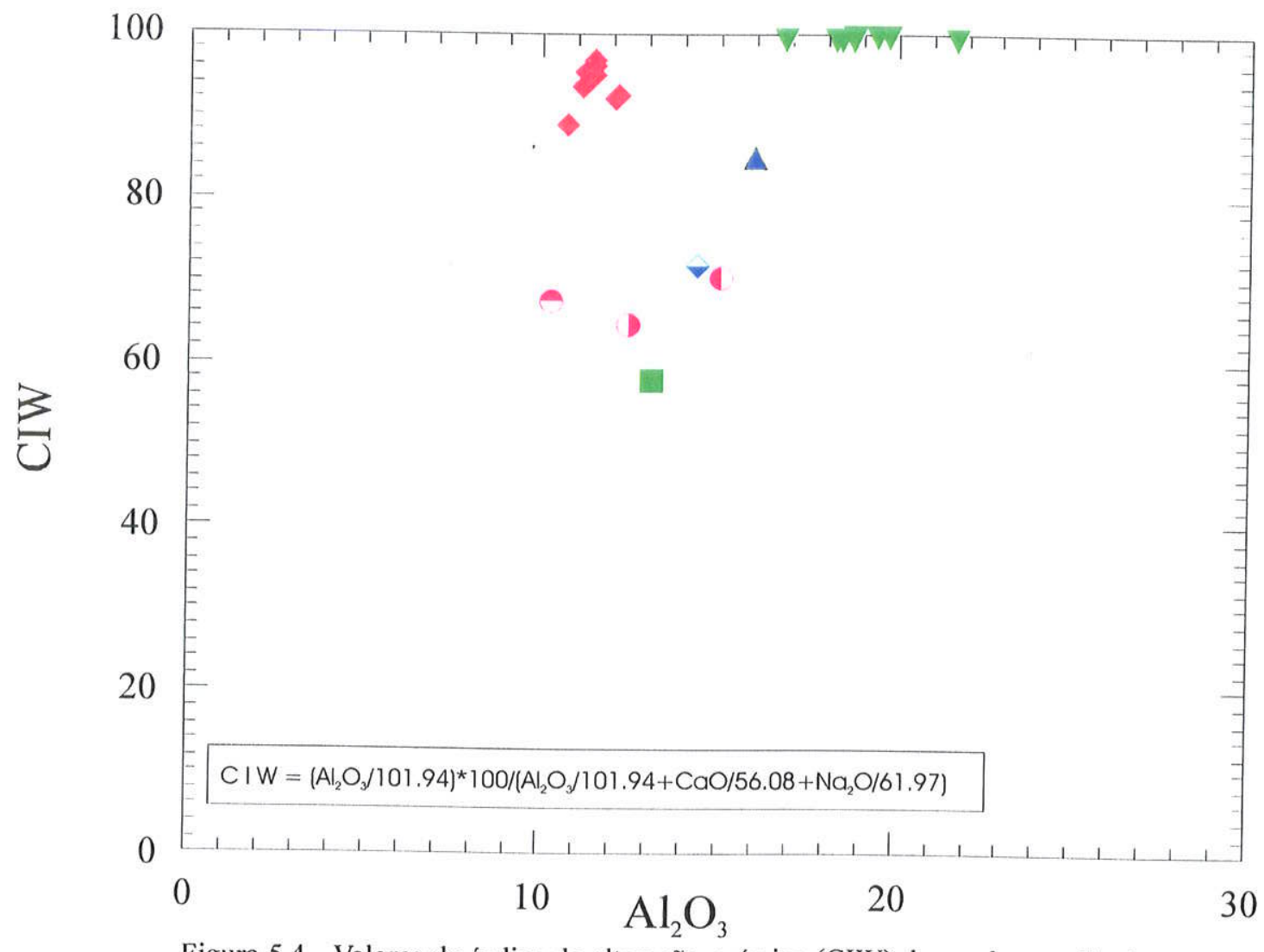

Figura 5.4 - Valores do índice de alteração química (CIW) das rochas analisadas versus $\mathrm{Al}_{2} \mathrm{O}_{3}(\mathrm{em} \% \mathrm{wt})$. Legenda na figura anterior. 
dessas rochas os valores ficam entre 82 e 98 , mostrando que para rochas sãs com alto $\mathrm{K}_{2} \mathrm{O}$, como é o caso dos riólitos, tal parâmetro não se aplica. Entretanto, ele pode explicar porque o índice CIA é relativamente baixo para os laminitos, enquanto o esperado, de acordo com Nesbitt \& Young (1982), deveria estar entre 90 e 100, se se considerar a possibilidade de uma retenção parcial e significativa de $\mathrm{K}_{2} \mathrm{O}$ da rocha original pelos argilo-minerais, gerados na diagênese, e o enriquecimento flagrante de $\mathrm{Al}_{2} \mathrm{O}_{3}$ devido ao mesmo processo e aos processos anquimetamórficos, com a neoformação de filossilicatos (sericita e illita, principalmente). De todo modo, as características fundamentais das rochas até a diagênese, em que pese a alteração intempérica, foram preservadas.

No caso dos laminitos, as cinzas vulcânicas intercaladas sofreram, ainda na diagênese, transformações mineralógicas que obliteraram grandemente suas características originais da fonte. Seus K-feldspatos foram transformados em argilo-minerais, provavelmente caolinita, e esta, posteriormente alterou-se na illita, como pode ser visto nos diagramas A-CN-K e A-CNKFM (Figura 5.5A e B). Na Figura 5.5B, de Nesbitt \& Young (1989), Toulkeridis et al. (1999) situam os trends das transformações diagenéticas ou metassomáticas da caolinita em illita e da caolinita em clorita, a partir de rochas ígneas graníticas ou basálticas, com fluídos, respectivamente, com altas razões de $\mathrm{K}^{+} / \mathrm{H}^{+}$e de $\mathrm{Mg}^{2+} / \mathrm{H}^{+}$. Como pode ser visto, os riólitos, em questão neste projeto, assumem posição quase extrema das rochas ígneas alcalinas, no ponto inicial do trend de alteração das rochas graníticas, os metassiltitos arenosos aparentam trends oriundos de rochas predominantes graníticas, ocorrendo o mesmo com os metalaminitos/cinzas vulcânicas com trend bem definido e deslocado para o segmento A-FM, entretanto sem continuidade até a rocha fonte, provavelmente também granítica, se projetado trend paralelo ao segmento A-CNK. Na Figura 5.5A, os metalaminitos/cinzas situam-se no campo da illita, principalmente, e muscovita, acima da média dos argilitos, o que significaria para McLennan $e t$ al. (1995) uma história de intensa alteração na área-fonte. Já os metassiltitos arenosos deslocamse dos feldspatos para os argilitos, sugerindo uma história de alteração branda.

McLennan et al. (1995) verificaram também que os processos de alteração influenciam as razões $\mathrm{Rb} / \mathrm{Sr}$ e $\mathrm{Th} / \mathrm{U}$ dos sedimentos. Razões $\mathrm{Rb} / \mathrm{Sr}$ inferiores a 1 denotariam alteração branda e superiores, alteração mais intensa. Razões $\mathrm{Th} / \mathrm{U}$ inferiores a 3 denotariam alteração branda e superiores a 4, alteração intensa. No caso dos metassiltitos arenosos, 3 amostras apresentam razões $\mathrm{Rb} / \mathrm{Sr}<1$ (CA-01, CA-18 e PA-15) e 3 outras (CA-11, CJ-06 e ET-64B) razões > 1; Para os metalaminitos/cinzas vulcânicas estas razões variam de 1,41 até 16,2 . As razões $\mathrm{Th} / \mathrm{U}$ nos metassiltitos arenosos é apenas inferior a 3 na amostra CJ-06 da Bacia Cajamar, nas demais 


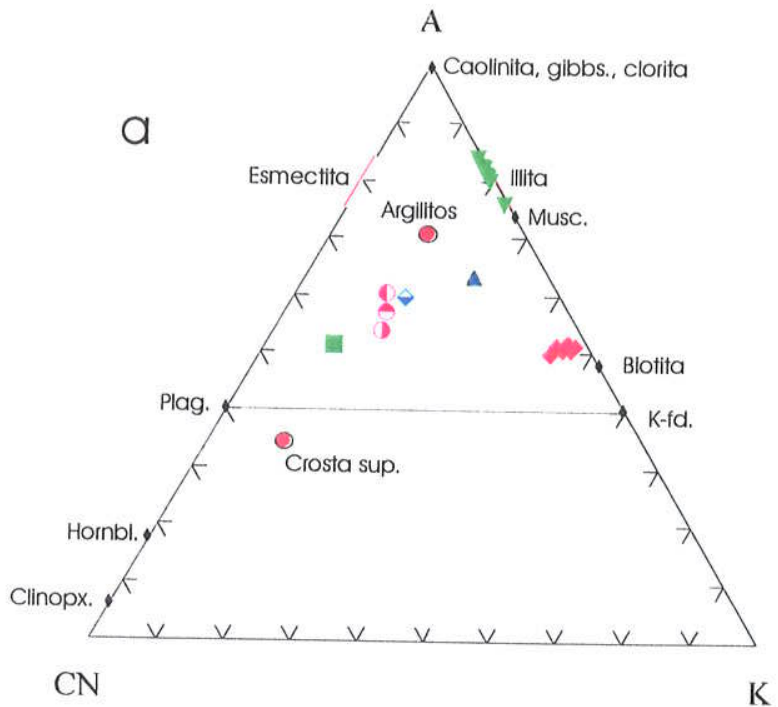

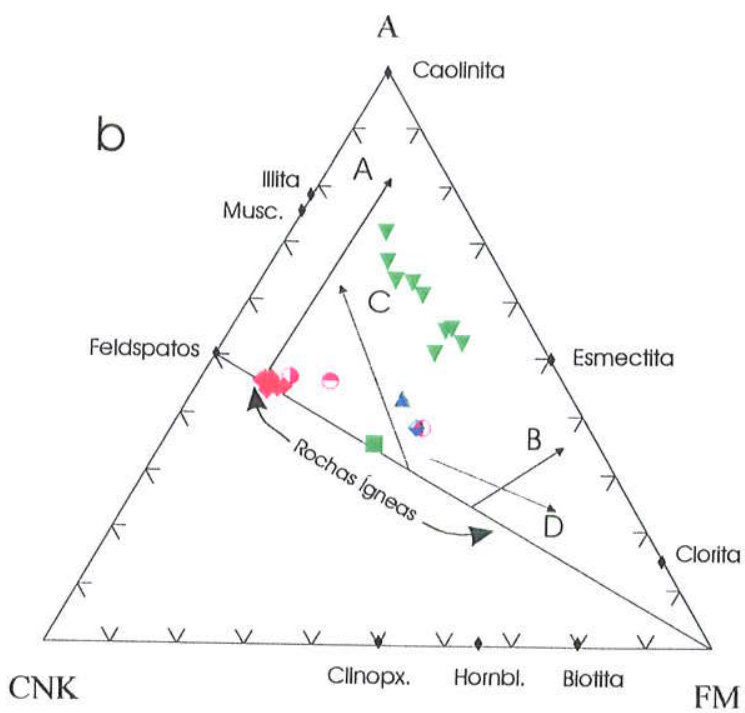

Figura 5.5 - Diagramas ternários A-CN-K e A-CNK-FM de Nesbitt \& Young (1989) modificados, respectivamente, por McLennan et al. (1995) e Toulkeridis et al. (1999). (a) Os metarenitos e metassiltitos desenvolvem tendência de alteração para os argilitos (composição média) e os metalaminitos com cinzas vulcânicas ocupam o campo da illita. (b) Os metarenitos e metassiltitos ocupam campos de alteração de rochas ígneas granitóides e os metalaminitos/cinzas seguem deslocados o trend das transformações diagenéticas e/ou metassomáticas da caolinita em illita. Os riólitos em ambos diagramas ocupam o campo de rochas ígneas. A- trend de alteração de fonte granítica, B- Irend de alteração de fonte basáltica, C- trend de transformação diagenética e/ou metassomática da caolinita em illita e D- trend de transformação diagenética e/ou metassomática da caolinita em clorita.

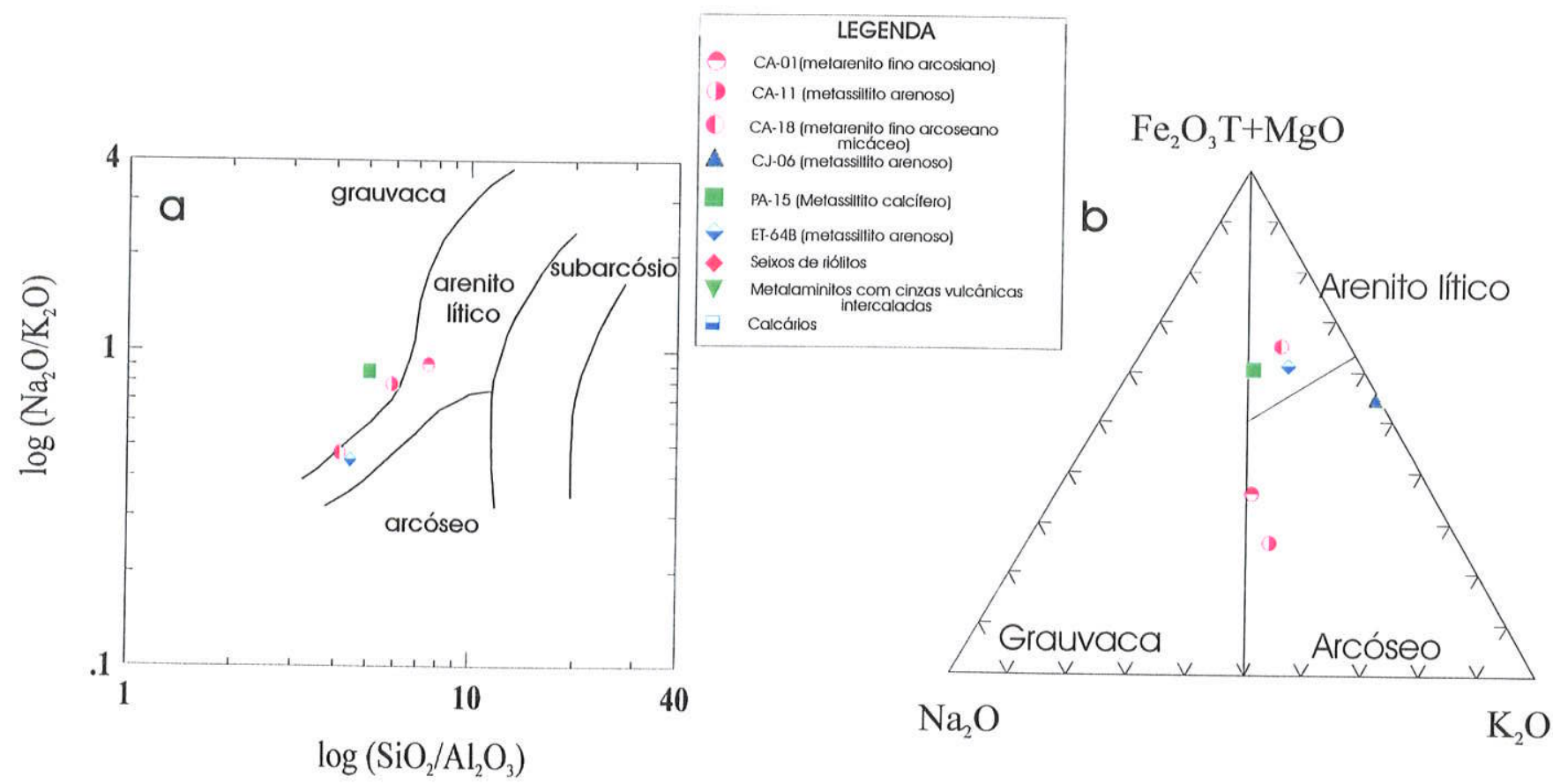

Figura 5.6 - Classificação dos metassedimentos: (a) segundo diagrama binário de Pettijohn et al. (1973), considerando o logarítmo das razões $\mathrm{SiO}_{2} / \mathrm{Al}_{2} \mathrm{O}_{3}$ versus $\mathrm{Na}_{2} \mathrm{O} / \mathrm{K}_{2} \mathrm{O}$ e (b) segundo diagrama ternário de Blatt et al. (1980), que considera as relações entre $\mathrm{Fe}_{2} \mathrm{O}_{3} \mathrm{~T}+\mathrm{MgO}, \mathrm{Na}_{2} \mathrm{O}$ e $\mathrm{K}_{2} \mathrm{O}$. 
superam 4,15 e atingem 6,5, valores superiores ao valor médio desta razão na crosta superior $(3,8)$. Nos metalaminitos/cinzas, as razões Th/U são inferiores a 4 (entre 3,1 e 3,88) e apenas a amostra VS-11 atinge valor 5. De acordo com McLennan et al. (1995), valores inferiores a 4 da razão $\mathrm{Th} / \mathrm{U}$ indicariam proveniência de mantos empobrecidos e, conseqüentemente, provável natureza vulcanogênica da fonte. Entretanto, no diagrama de comportamento de elementos traços (Figuras 5.12B e 5.12D ), normalizados pelo Condrito (Taylor \& McLennan 1985), pode ser visto o pequeno enriquecimento de $U$ com relação ao Th, o que pode ter ocorrido, também, durante processos metassomáticos (McLennan et al. 1995). Conclui-se, portanto, que os parâmetros $\mathrm{Rb} / \mathrm{Sr}$ e $\mathrm{Th} / \mathrm{U}$ assinalam trajetórias de alteração contraditórias para os metassedimentos, não fornecendo subsídios suficientes para conclusões seguras.

Nos diagramas clássicos de Pettijohn et al. (1973) e de Blatt et al. (1980) para classificação de rochas sedimentares arenosas, tendo-se como referências os elementos maiores $\left(\mathrm{SiO}_{2}, \mathrm{Al}_{2} \mathrm{O}_{3}, \mathrm{Na}_{2} \mathrm{O}, \mathrm{K}_{2} \mathrm{O}, \mathrm{Fe}_{2} \mathrm{O}_{3} \mathrm{~T}\right.$ e $\mathrm{MgO}$ ), os sedimentos terrígenos estariam classificados como arenitos líticos e arcóseos (Figura 5.6A) e arenitos líticos e grauvacas (Figura 5.6B).

Quanto à proveniência dos depósitos, utilizando-se, também, elementos maiores, Roser \& Korsch (1988) calcularam para uma população de várias centenas de amostras as funções discriminante $\mathrm{F} 1$ e F2 de áreas-fonte ígnea (P1), ígnea intermediária (P2), ígnea félsica (P3) e sedimentar quartzosa (P4). No diagrama F1xF2 (Figura 5.7) de Roser \& Korsch (1988), as amostras de laminitos com cinzas vulcânicas transitam pelos limites entre P2, P3 e P4, dando conta de contribuição de áreas-fonte ígneas intermediárias e félsicas, mas principalmente, também, de terrenos sedimentares ou metassedimentares já maturos. As amostras de metassiltitos e arenitos transitam pelos limites de P3 com P4, definindo-se predominantemente no campo P4, de rochas ígneas félsicas. Para esses grupos de amostras as razões $\mathrm{K}_{2} \mathrm{O} / \mathrm{Na}_{2} \mathrm{O}$ são próximas de 0 para os metassiltitos e metarenitos e, ao redor de 50, para os laminitos com cinzas vulcânicas, enquanto as razões $\mathrm{SiO}_{2} / \mathrm{Al}_{2} \mathrm{O}_{3}$ e $\mathrm{Fe}_{2} \mathrm{O}_{3} \mathrm{~T}+\mathrm{MgO}$ apresentam valores equilibrados para ambos os grupos, respectivamente, ao redor de 2-3 e 2-9. Considerando que os valores de $\mathrm{K}_{2} \mathrm{O}$ são próximos para ambos, as variações significativas ocorreram com o empobrecimento significativo de $\mathrm{Na}_{2} \mathrm{O}$ para os metalaminitos (com valores próximos de 0 ), enquanto os metassiltitos e metarenitos têm esses valores entre 1,5 e 3\%wt. Desse modo, nos metalaminitos com cinzas o crescimento da razão $\mathrm{K}_{2} \mathrm{O} / \mathrm{Na}_{2} \mathrm{O}$ durante os processos de sedimentação/maturação deveu-se ao elevado empobrecimento de $\mathrm{Na}_{2} \mathrm{O}$, provavelmente deslocando o trend desse grupos de posições P3 ('́gnea félsica) para P4 (sedimentar quartzosa). Poderia, também, ser explicado pela alteração 


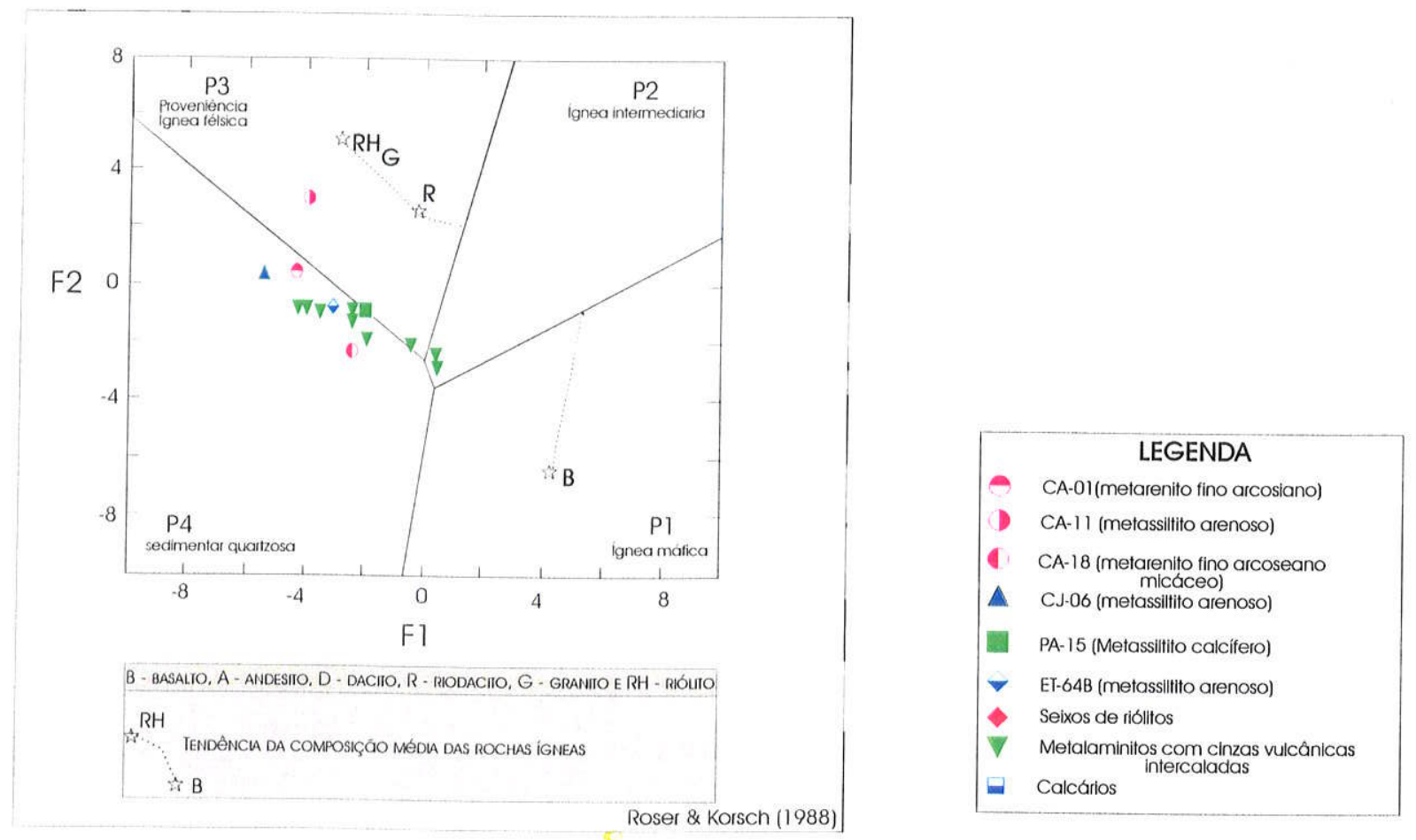

Figura 5.7 - Possível proveniência dos metassedimentos utilizando-se diagrama com as funções discriminantes F1 e F2, de Roser \& Korsch (1988). As amostras de metalaminitos com cinzas vulcânicas transitam pelos campos P2 (ígnea intermediária) e P3 (ígnea félsica), mas se definem, na maioria, no campo P4 (sedimentar quartzosa). A amostra CA-18 situa-se no campo P3. A amostra PA-15 situa-se no limite dos campos P3 e P4. As demais situam-se no campo P4, próximas do limite com P3.

$\mathrm{F} 1^{*}=-1.773 \mathrm{TiO}_{2}+0.607 \mathrm{Al}_{2} \mathrm{O}_{3}+0.76 \mathrm{Fe}_{2} \mathrm{O}_{3} \mathrm{~T}-1.5 \mathrm{MgO}+0.616 \mathrm{CaO}+0.509 \mathrm{Na}_{2} \mathrm{O}-1.224 \mathrm{~K}_{2} \mathrm{O}-9.09$

$\mathrm{F} 22^{*}=0.445 \mathrm{TiO}_{2}+0.07 \mathrm{Al}_{2} \mathrm{O}_{3}-0.25 \mathrm{Fe}_{2} \mathrm{O}_{3} \mathrm{~T}-1.142 \mathrm{MgO}+0.438 \mathrm{CaO}+1.475 \mathrm{Na}_{2} \mathrm{O}+1.426 \mathrm{~K}_{2} \mathrm{O}-6.861$.

(*Em proporções moleculares)

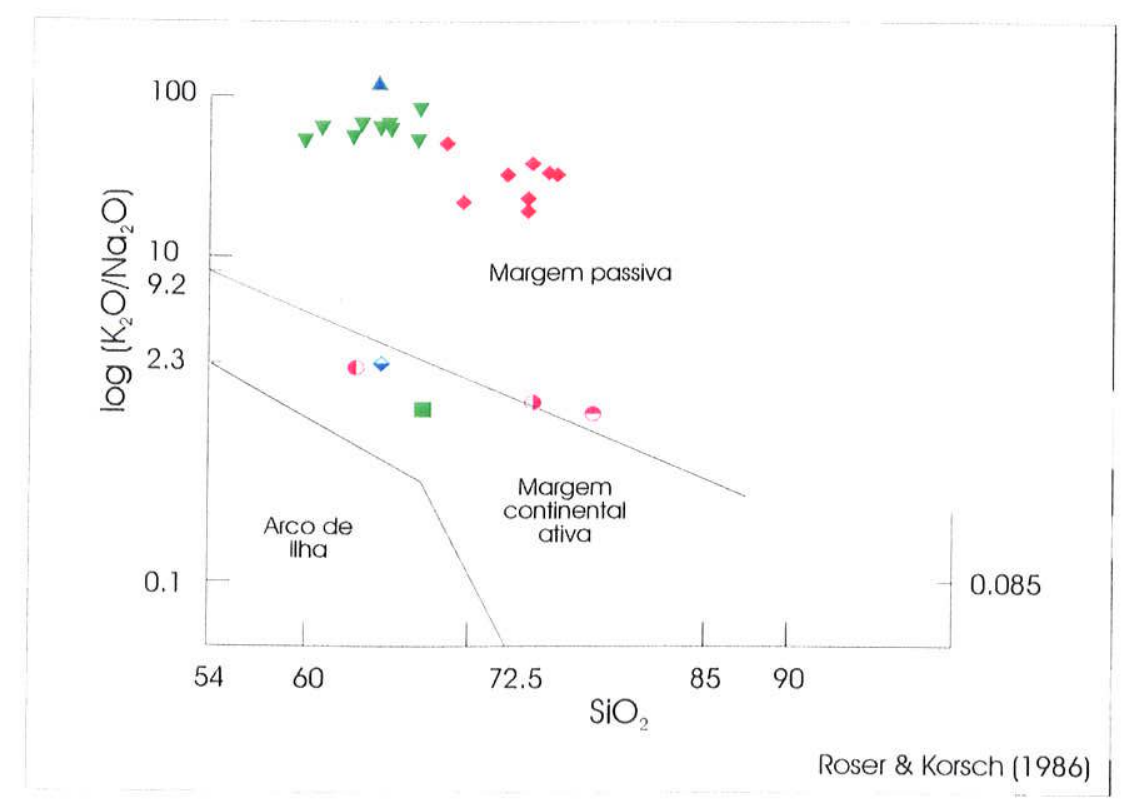

Figura 5.8 - Ambientes tectônicos para a sedimentação, considerando-se as relações entre $\mathrm{SiO}_{2}$ e o logarítmo da razão $\mathrm{K}_{2} \mathrm{O} / \mathrm{Na}_{2} \mathrm{O}$, segundo proposta de Roser \& Korsch (1986). Os metassedimentos situam-se nos campos de margem continental ativa/passiva e os metalaminitos com cinzas vulcânicas situam-se no campo de margem passiva, bem deslocados das demais, juntos com a amostra CJ-06. 
intempérica moderna desse grupo, que o coloca com valores de CIA próximos de 81, enquanto os metassiltitos e metarenitos situam-se entre 50 e 60 .

Quanto ao ambiente tectônico para a sedimentação, as relações $\mathrm{SiO}_{2} \times \log \left(\mathrm{K}_{2} \mathrm{O} / \mathrm{Na}_{2} \mathrm{O}\right)$ expressas no diagrama de Roser \& Korsch (1986), Figura 5.8, indicam ambiente predominantemente de margem continental ativa para os metassiltitos/arenitos e de margem continental passiva para os laminitos com cinzas vulcânicas, mas situados com altíssimos valores de $\mathrm{K}_{2} \mathrm{O} / \mathrm{Na}_{2} \mathrm{O}$ no diagrama, evidenciando novamente a interferência do baixo $\mathrm{Na}_{2} \mathrm{O}$ com valores mais altos ainda, destaca-se a amostra de metassiltito/arenito da Bacia de Cajamar, CJ-06.

Nos diagramas de Bhatia (1983), os metassiltitos/arenitos transitam entre ambientes de margem passiva a arco de ilha oceânico (Figura 5.9A), se tomadas as relações $\left(\mathrm{Fe}_{2} \mathrm{O}_{3} \mathrm{~T}+\mathrm{MgO}\right)$ $\mathrm{x} \mathrm{TiO}_{2}$, e entre margem continental ativa até arco oceânico (Figura 5.9B) para as relações entre $\left(\mathrm{Fe}_{2} \mathrm{O}_{3} \mathrm{~T}+\mathrm{MgO}\right) \times \mathrm{Al}_{2} \mathrm{O}_{3} / \mathrm{SiO}_{2}$. Com valores altos nesta última razão, os metalaminitos/cinzas vulcânicas não se definiram em nenhum dos campos.

Considerando-se as relações logarítmicas entre $\mathrm{Ba}$ e $\mathrm{Sr}$, propostas por Floyd et al. (1989) para a classificação de sedimentos metamorfizados (Figura 5.10), os metalaminitos/cinzas vulcânicas estariam no campo dos sedimentos maturos. Os metassiltitos/arenitos ocupariam predominantemente o campo dos pelitos (mudstones) com incursões da amostra CA-18, da Bacia Camarinha, no campo das grauvacas e da amostra CJ-06, metassiltito arenoso da Bacia de Cajamar, no campo dos sedimentos maturos. As rochas carbonáticas de Cajamar e do Subgrupo Lageado ocupam os limites entre os campos de "sedimentos carbonáticos" (CJ-01, CJ-02 e NC23) e de "grauvacas" (CJ-04, CJ-07 e NC-08B), com uma incursão (amostra CJ-03) no campo dos "pelitos".

Os riólitos variam a composição de $\mathrm{SiO}_{2}$ entre 68,40 a 75,44 \%wt, de $\mathrm{K}_{2} \mathrm{O}$ entre 9,78 a $8,75 \%$ wt e de $\mathrm{Na}_{2} \mathrm{O}$ entre 0,19 e $0,50 \% \mathrm{wt}$, situando-os no diagrama discriminante de rochas vulcânicas (TAS) de Le Maitre (1989), no campo dos riólitos alcalinos (Figura 5.11). A análise dos elementos traços normalizados segundo Taylor \& McLennan (1985) para Condrito (Figura 5.12B), mostram empobrecimento para ao elementos $\mathrm{Rb}$, $\mathrm{Sr}$ e $\mathrm{Ti}$, sendo mais acentuadas para $\mathrm{Rb}$ e Ti. Seguindo a mesma normalização, o diagrama para elementos terras raras (Figura 5.12A), mostra um empobrecimento geral de Eu e pequenos empobrecimentos de 2 amostras e enriquecimentos, também pequenos, em 2 outras. Verifica-se, também, enriquecimentos em Ce em 4 amostras, enquanto as demais amostras seguem tendência normal. 

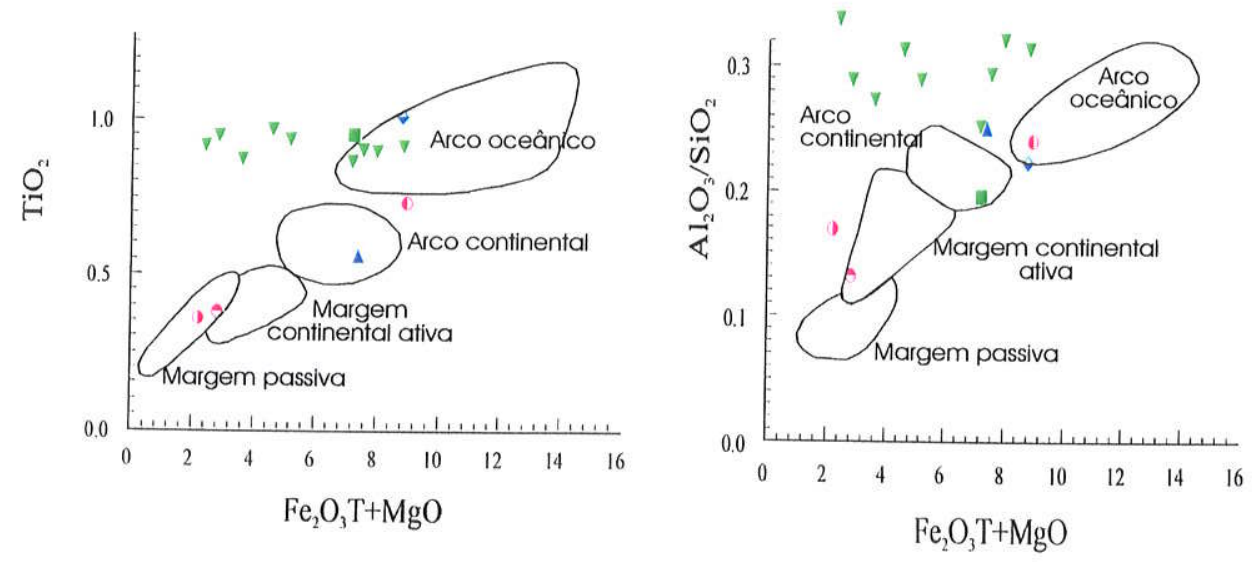

Figura 5.9 - Ambientes tectônicos para a sedimentação propostos por Bhatia (1983), tomando-se (a) as relações de $\left(\mathrm{Fe}_{2} \mathrm{O}_{3} \mathrm{~T}+\mathrm{MgO}\right)$ versus $\mathrm{TiO}_{2} \mathrm{e}(\mathrm{b})$ as relações de $\left(\mathrm{Fe}_{2} \mathrm{O}_{3} \mathrm{~T}+\mathrm{MgO}\right)$ versus $\left(\mathrm{Al}_{2} \mathrm{O}_{3} / \mathrm{SiO}_{2}\right)$.
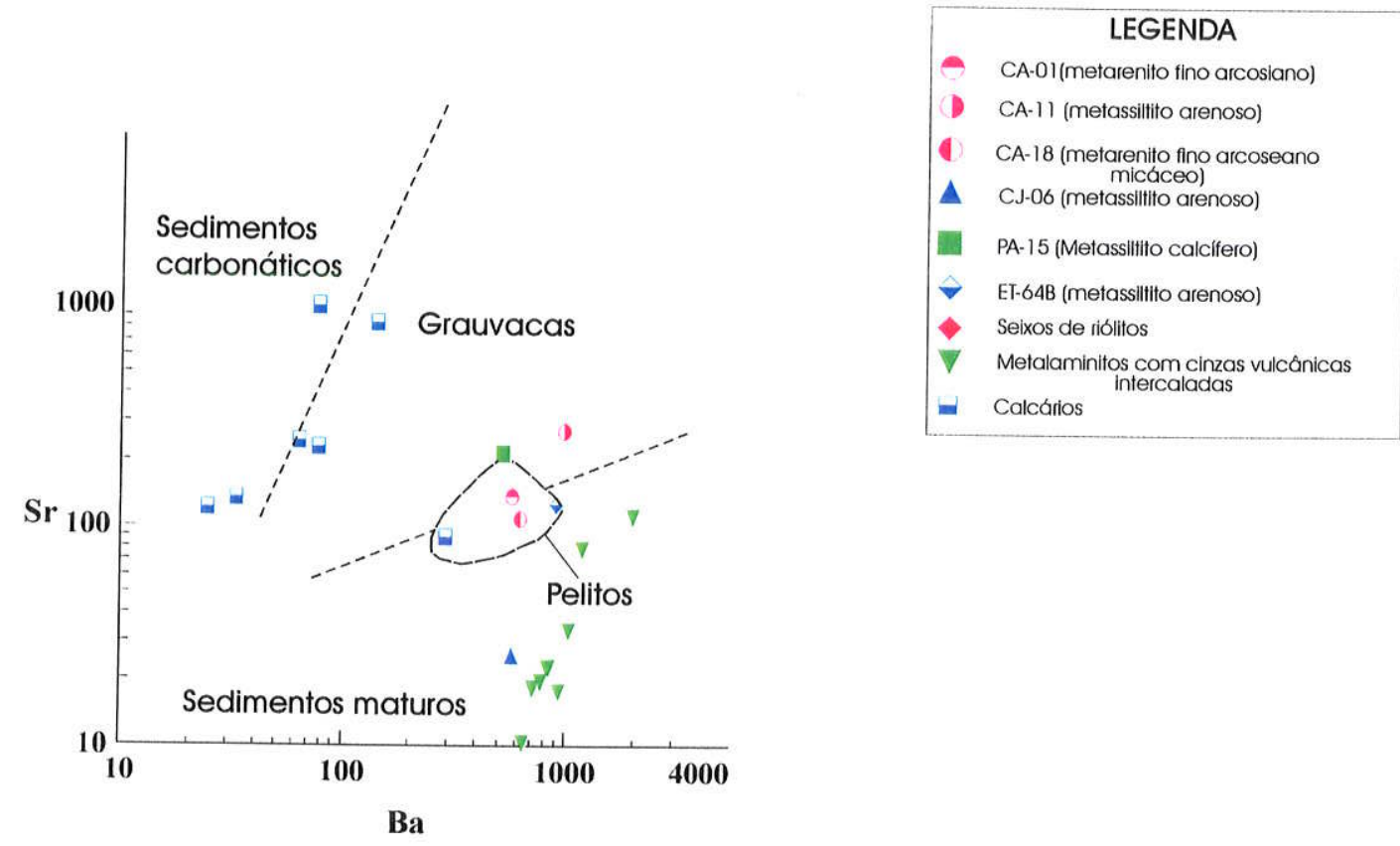

Figura 5.10 - Diagrama bi-logarítmo de Floyd et al. (1989) para a classificação de sedimentos, tomando as relações Ba versus $\mathrm{Sr}(\mathrm{em} \mathrm{ppm})$. 
Quanto ao ambiente tectônico, definem-se no diagrama R1xR2 de Batchelor \& Bowden (1985), no campo dos granitóides posorogênicos (campo 7, Figura 5.13) com leve tendência ao campo anorogênico (campo 5). Considerando-se as características de alta $\mathrm{SiO}_{2}$ e altíssimo $\mathrm{K}_{2} \mathrm{O}$ dos riólitos, o ambiente proposto no diagrama é compatível com a composição química das rochas que, por sua vez, é típica dos estágios finais da diferenciação magmática. O líquido residual estaria rico em álcalis, empobrecido em $\mathrm{Rb}, \mathrm{Sr}$ e $\mathrm{Ti}$, pela remoção do plagioclásio e minerais máficos durante a diferenciação magmática e empobrecidos em Eu (razões Eu/Eu* $<1$, entre 0,10 e 0,36), assinalando, também, a cristalização fracionada com remoção de plagioclásio.

Os padrões de comportamento para os elementos traços, normalizados segundo normalização adotada por Vlach (1993), mostram grande similaridades entre o comportamento destes riólitos e os granitóides de Morungaba, em especial com amostra de microgranito do Plúton Meridional, amostra 304c. Diferenciam-se apenas no comportamento do $\mathrm{Yb}$, o qual, nos clastos riolítos aqui analisados, mostra grande enriquecimento, enquanto nos granitóides de Morungaba apresenta pequeno empobrecimento, o que pode ser explicado pela normalização adotada pelo autor, preferencialmente para rochas de composição diorítica. Entretanto, deve ser ressalvado o pequeno enriquecimento deste elemento com a normalização segundo Taylor \& McLennan (1985).

Comportamento similar também apresentam os diagramas para terras raras dos riólitos em questão e os granitóides Morungaba, nos quais ocorre pequeno enriquecimento dos elementos leves, no sentido do La, pequenas anomalias positivas e negativas de Ce e anomalia negativa geral de Eu, evidenciando o fracionamento mineral durante a diferenciação magmática, com remoção de plagioclásio. O patamar dos elementos pesados é suave, plano-horizontal. A amostra $304 \mathrm{c}$ de Morungaba, neste caso, destoa quanto ao comportamento dos elementos leves, apresentando patamar horizontalizado.

Comparativamente aos diagramas R1xR2, de Batchelor \& Bowden (1985), contidos em Vlach (1993), enquanto os plútos granitóides de Morungaba definem-se no campo 6 (sincolisionais) com tendência ao 4 (tardi-orogênicos), os riólitos dos metaconglomerados da Bacia Eleutério definem-se no campo 7 (posorogênicos), colocando-os, hipoteticamente, como o extremo da diferenciação magmática.

Considerando as similaridades acima apontadas, as datações obtidas em cristais de zircão dos seixos de riólitos (U/Pb, SHRIMP), que apontaram idade máxima para a sedimentação ao redor de $606 \mathrm{Ma}$, e as idades obtidas em Morungaba por Vlach (1993), situadas entre 590-620 

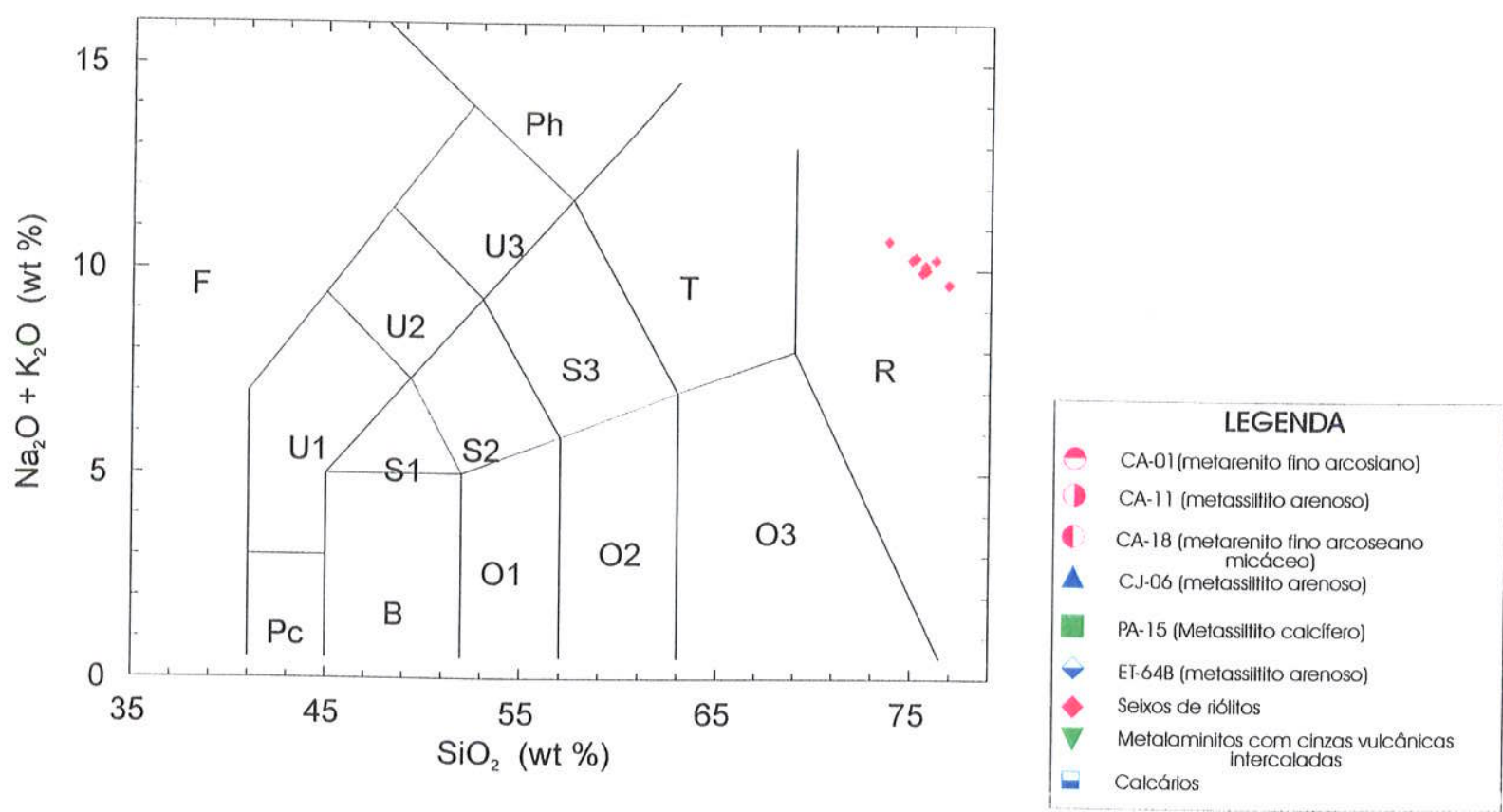

Figura 5.11 - Diagrama de classificação de rochas vulcânicas de Le Maitre (1989), no qual os seixos de riólitos situamse no campo dos riólitos alcalinos.
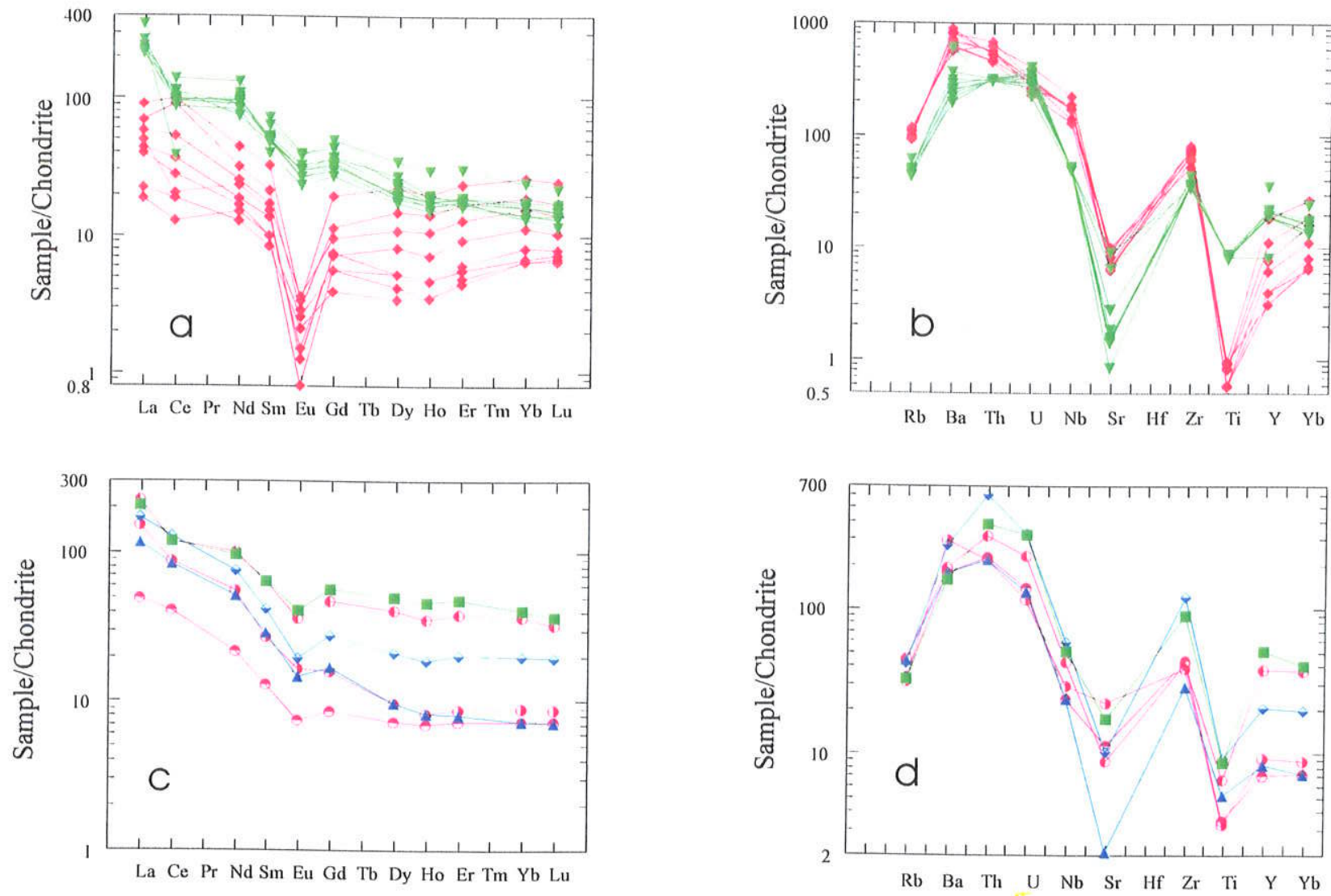

Figura 5.12 - Padrões comportamentais para os riólitos e metalaminitos com cinzas vulcânicas quanto aos elementos terras raras (a) e elementos traços (b) e para os metassiltitos e metarenitos, quanto aos elementos terras raras (c) e elementos traços (d). Valores normalizados segundo Condrito de Taylor \& McLennan (1985). 


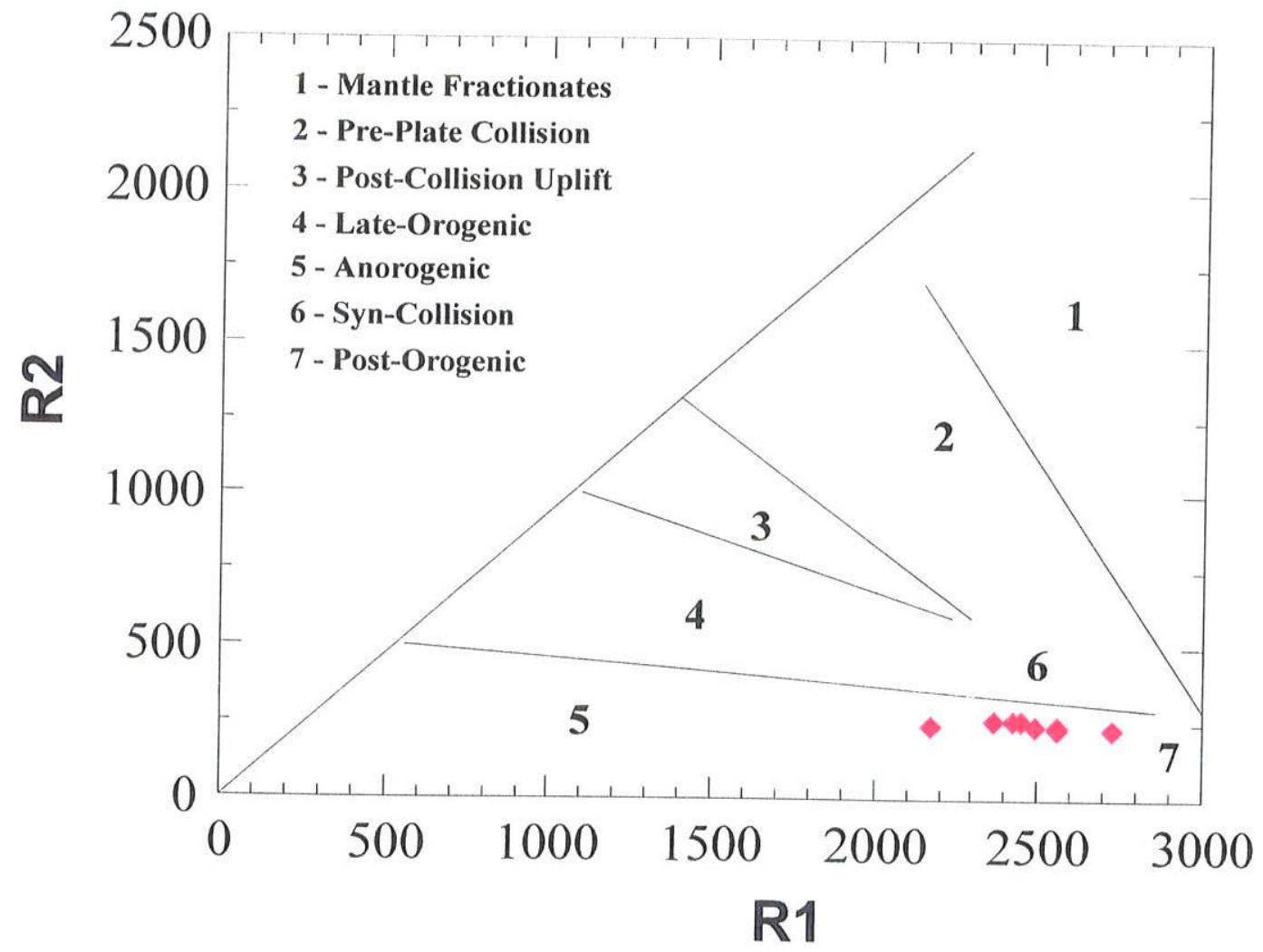

Figura 5.13 - Diagrama R1 x R2 de Batchelor \& Bowden (1985), no qual os seixos de riólitos situam-se no campo dos granitóides pós-orogênicos (7), com leve tendência para o campo anorogênico (5).

Ma, torna-se plausível identificar edifícios vulcânicos já exumados daquele maciço, além de outros a este correlacionáveis na região, como potencial área-fonte dos seixos riolíticos.

O padrão de comportamento entre os metassiltitos e metarenitos no diagrama de elementos traços (Figura 5.12D) é bastante similar para as amostras das diferentes bacias. Pequenas variações ocorrem apenas nos valores de $\mathrm{Sr}$, com enriquecimento relativo na amostra CA-18 (metarenito fino arcosiano do corpo sul da Bacia Camarinha) e empobrecimento mais acentuado para metassiltito arenoso da Bacia de Cajamar (CJ-06). Grosso modo, tal padrão se aproxima daquele dos seixos de riólitos, sendo estes mais empobrecidos em Ti e enriquecidos em Yb. Aproximam-se também do padrão de comportamento dos laminitos com cinzas vulcânicas (Figura 5.12B), sendo estes um pouco mais empobrecidos em $\mathrm{Sr}$.

Quanto aos elementos terras raras (Figura 5.12C), o padrão de comportamento é também bastante similar para todos as amostras, apresentando-se enriquecidas na série de elementos leves, com anomalia negativa pouco acentuada de Eu e tendência suborizontal para os elementos pesados, apenas com pequenas rotações horárias nas amostras CJ-06 e CA-18. As similaridades 
com os metalaminitos/ cinzas vulcânicas seriam boas, não fosse pela tendência de empobrecimento geral dos elementos pesados que estes últimos apresentam (Figura 5.12A).

E, finalmente, consideradas as características acima descritas, é possível afirmar proveniência de rochas ígneas para todos os metassedimentos analisados (anomalia negativa de $\mathrm{Eu}$ ), com posteriores retrabalhamentos (ressedimentação com fracionamento granulométrico) e processos anquimetamórficos que alteraram mais significativamente as razões $\mathrm{Rb} / \mathrm{Sr}$. 


\section{CORRELAÇÕES ENTRE AS BACIAS DA TRANSIÇÃO}

As bacias da transição Proterozóico-Fanerozóico, do Estado de São Paulo e adjacências, possuem similaridades estratigráficas e sedimentológicas entre si que permitem correlacioná-las. As dificuldades encontradas para fazê-lo ativeram-se, principalmente, quanto à caracterização das feições sedimentológicas e fácies sedimentares, dos paleo-ambientes deposicionais e, de modo mais crucial, em estabelecer idades para a deposição, uma vez que o conteúdo fossilífero e a presença de vulcanismo sin-sedimentar foram considerados, até então, ausentes.

Neste estudo, acredita-se que foram gerados subsídios que contribuem para elucidar a história geológica das bacias da transição, que serão considerados a seguir:

\subsection{Idades absolutas para a deposição}

A idade da sedimentação, tendo-se como parâmetros datações radiométricas, estaria situada no intervalo aproximado de 606-530 Ma. A idade máxima para o início da sedimentação foi obtida em seixos de riólitos contidos em metaconglomerado polimítico da Bacia de Eleutério, pelo método U/Pb (SHRIMP), por Teixeira et al. (1999), e a idade mínima foi obtida nos mesmos seixos, pelo método K-Ar em rocha-total, por Teixeira (1996). Tal intervalo poderia ser estendido para as demais bacias, considerando-se o significado tectônico de cada um dos limites. O limite inferior de $606 \mathrm{Ma}$ marcaria os eventos finais da intensa granitogênese brasiliana, associada à amalgamação de blocos crustais, que afetou todo o Gondwana Ocidental, perdurando até por volta de $580 \mathrm{Ma}$ (Vlach 1993 e Brito-Neves et al. 1999). Cordani et al. (1999) relataram idades médias, obtidas pelo método U/Pb (SHRIMP) em monocristais de zircão de rochas vulcânicas ácidas intercaladas nos metassedimentos, ao redor de $595 \mathrm{Ma}$, para a Bacia de Campo Alegre, de 563Ma, para a Bacia de Itajaí, e de $543 \mathrm{Ma}$, para a Bacia de Castro. Basei et al. (1999), baseando-se em análises U/Pb (SHRIMP), sugeriram um limite inferior de $570 \mathrm{Ma}$ para o início da sedimentação na Bacia de Itajaí e a correlacionaram, quanto ao ambiente tectônico, com as bacias de foreland, como a de Camarinha.

O limite superior (530 Ma) marcaria a fase de encurtamento e inversão dessas bacias, quando a tectônica predominante era de ajustamento entre os blocos crustais amalgamados, ainda sob efeito do resfriamento pós-orogênico, que adquiriram movimento relativo destrogiro sob a égide predominante de binários de esforços ao longo de zonas de cisalhamentos empinadas, outrora de baixo ângulo. A idade K-Ar obtida em seixo riolítico da Bacia de Eleutério é 
compatível com aquela dos metassiltitos calcíferos da Bacia de Pouso Alegre, obtida pelo mesmo método por Hama \& Cunha (1977). Schmitt et al. (1999) reportaram à orogenia cambroordoviciana (530-490 Ma) ocorrida no Bloco Cabo Frio (Orogenia Búzios), a qual consideraram extensiva a toda Faixa Ribeira, concordando com Basei et al. (1987), Macedo et al. (1984), entre outros, e que marcaria os episódios finais de amalgamação do Gondwana. Santoro (1998) e Santoro \& Silva (1999) também relataram resfriamento das rochas do embasamento da região do Pico de Itapeva entre 530 470 Ma, concordando com idades K-Ar em biotita da Faixa Ribeira. É bem possível, portanto, que as idades K-Ar obtidas por Hama \& Cunha (1977) e Teixeira (1996) estejam relacionadas a esses eventos cambro-ordovicianos (e.g. Orogenia Búzios), que imprimiram às bacias da transição uma tênue clivagem ardosiana associada a metamorfismo de grau muito baixo, o que ocorreu concomitantemente à sua inversão e encurtamento.

\subsection{Idades relativas para a deposição}

Considerando-se as datações paleontológicas, ainda em estágio inicial das sistematizações, é possível propor que a sedimentação tenha ocorrido entre 570-540 Ma, baseando-se em correlações com a Formação Yerbal, unidade basal do Grupo Arroyo del Soldado (Uruguai), a qual tem conteúdo fossilífero bastante similar ao encontrado nas bacias aqui analisadas. Destaca-se a ocorrência do microfóssil Cloudina riemkeae GERMS 1972, com intervalo de existência bem estabelecido mundialmente no intervalo de 565-543 Ma, Neoproterozóico III (Knoll 1996, apud Gaucher 2000), encontrado em rochas do Grupo Nama, Namíbia, e também em rochas do Grupo Corumbá (Zaine 1991 e Zaine \& Fairchild 1985). Nas bacias da transição, em estudo, confirmou-se a ocorrência do microfóssil Cloudina nos laminitos da Bacia de Eleutério e do Pico de Itapeva e a possibilidade de que também ocorra nas bacias de Cajamar e de Pouso Alegre. O microfóssil Titanotheca coimbrae GAUCHER \& SPRECHMANN 1999, também identificado por Gaucher \& Sprechmann (1999) na Formação Yerbal, do Grupo Arroyo del Soldado, ocorre nas bacias do Pico de Itapeva e de Cajamar. O seu significado cronoestratigráfico, segundo os autores, ainda não é claro. Gaucher \& Sprechmann (1999) aventaram a hipótese de haverem se desenvolvido a partir do final do Vendiano. Tratando-se de forma esqueletal (da Ordem Foraminiferida), desenvolveu carapaça a partir da aglutinação, provavelmente, de micro-cristais de rutilo, que os autores supracitados interpretaram como uma medida de defesa frente a predadores mais desenvolvidos, que, no final do Vendiano, iniciavam grande proliferação. O microfóssil Cloudina, mais desprotegido, viria a se extinguir no 
início do Cambriano, enquanto o Titanotheca coimbrae, provavelmente, tenha perdurado para além dos limites do Cambriano Inferior.

A "preferência" do microfóssil Titanotheca em aglutinar um mineral tão exótico como o rutilo chama a atenção. Entretanto, Loeblich Jr. \& Tappan (1964) e Lowenstam \& Weiner (1989) destacaram que a diversidade de minerais escolhidos pelos foraminíferos para a constituição de suas carapaças é muito grande e já bastante conhecida dos pesquisadores, tanto nas espécies recentes quanto naquelas mais antigas. Além dos aglutinados mais comuns, como minerais carbonáticos inorgânicos (calcita e aragonita) e bioclásticos e os minerais de quartzo (incluindo micro-partículas de vidro vulcânico), eles podem aglutinar uma infinidade de outros minerais, incluindo uma vasta gama de minerais pesados e leves, como piroxênio, hornblenda, mica, feldspato, etc, além da glauconita e até o rutilo. Dick (1928, apud Loeblich Jr. \& Tappan 1964 e Lowenstam \& Weiner 1989) descreveram no estuário de Clyde, costa oeste escocesa, e em regiões norueguesas do Mar do Norte, em foraminífero recente (Bathysiphon argenteus), carapaças de aglutinados de cristais de rutilo e minerais micáceos. Nestas regiões, segundo os autores, o assoalho oceânico é constituído também de xistos rutilíferos que, certamente disponibilizaram o rutilo para que a espécie constituísse sua carapaça. Loeblich Jr. \& Tappan (1964) e Lowenstam \& Weiner (1989) consideraram que ainda constitui um mistério a ser desvendado, o porquê de tamanha diversidade de aglutinados à qual recorrem os foraminíferos. Apontam, entretanto, que para o melhor entendimento dessa questão seriam necessários estudos mais aprofundados, que levassem em conta as características ecológicas do ambiente e a performance metabólica dessas espécies.

A ocorrência de Titanotheca coimbrae é também possível de ser confirmada em intraclastos de metassiltitos de conglomerados polimíticos da Bacia de Camarinha, baseado no exame ainda expedito de amostras coletadas. Na Bacia de Pouso Alegre, foram confirmadas a presença dos acritarcas Soldadophycus major GAUCHER 2000 e Symplassosphaeridium sp. O microfóssil Soldadophycus major ocorre em metassiltitos da Formação Yerbal, em calcários da Formação Polanco, e em formações ferríferas e folhelhos da Formação Cerro Espuelitas, no Uruguai. Symplassosphaeridium ocorre em ambas e na unidade de topo do Grupo Arroyo del Soldado, Formação Cerro Victória, de idade cambriana inferior (Gaucher \& Sprechmann 1999). Entretanto, ainda não há definição do significado cronoestratigráfico desses microfósseis.

Espera-se que as novas ocorrências desses microfósseis na Bacia de Pouso Alegre possam contribuir para a elucidação tanto do seu significado cronoestratigráfico, quanto bioestratigráfico, à medida que evoluam as análises paleontológicas sistemáticas em curso. 
Em resumo, o intervalo proposto de 570-540 Ma firma-se, fundamentalmente, na ocorrência de Cloudina riemkeae em algumas das bacias, podendo, talvez, ser estendido para as demais.

\subsection{Estratigrafia e sedimentação}

A sedimentação nas bacias da transição processou-se em ambientes continentais subaéreos, transicionais a marinhos rasos. No continente, o estilo deposicional sempre foi controlado por leques aluviais associados a regiões soerguidas, às vezes com desenvolvimento de planície aluvial mais ampla, mas, em geral, suas porções medianas e distais atingiam diretamente corpo d'água marinho, dando conta de uma boa proximidade entre as áreas-fonte e a linha de costa.

Na Bacia de Eleutério, entre a zona escarpada com leques aluviais coalescentes e a linha de costa, desenvolveu-se extensa planície aluvial com rios entrelaçados (braided) onde puderam ser preservadas, também, feições de retrabalhamento eólico. Apenas à frente desta (à jusante) é que os canais entrelaçados encontravam o corpo d'água com o desenvolvimento de planície deltaica com predomínio de granulações grossas (sentido McPherson et al. 1987), evidenciada nos sucessivos e cíclicos afogamentos de corpos com areias conglomeráticas, que ora constituíam seqüências granocrescentes, ora granodecrescentes, junto a termos pelíticos. Tais seqüências na Bacia de Eleutério evidenciam, pelo menos, 3 ciclos transgressivo-regressivos (intercalações sucessivas e alternadas das fácies $A_{3} \operatorname{com} B_{1}$ e $B_{2}$ ), que da base (SE) para o topo (NW) sugerem granocrescência geral até o predomínio de condições francamente regressivas, com a progradação de metarenitos conglomeráticos arcosianos de rios entrelaçados (fácies $\mathrm{A}_{2}$ ), sucedidos por conglomerados arenosos das porções medianas e distais de leques aluviais (fácies $A_{1}$, de depósitos de fluxos densos canalizados e de enxurradas). Com o início da inversão da bacia, as áreas-fonte estabeleceram-se em regiões soerguidas a sudeste, onde se instalou sistema de leques aluviais. Os depósitos proximais destes leques (conglomerados polimíticos)

progradavam diretamente sobre os depósitos distais subaquosos (ritmitos silto-argilosos), oriundos de noroeste.

Nas demais bacias, as regiões escarpadas onde se desenvolveram sistemas de leques aluviais, estiveram relativamente mais próximas da linha de costa do que na Bacia de Eleutério, o que pode ser evidenciado na constante associação dos termos conglomerados-pelitos e/ou conglomerados-arenitos, constituindo intercalações aparentemete cíclicas, desenvolvidas sob 
lâmina d'água em ambientes litorâneos. Na Bacia do Pico de Itapeva encontram-se preservados pacotes de areias praiais, nas quais destacam-se a tabularidade e laminação de estratos planohorizontais e cruzados de baixo ângulo com prováveis estruturas de tempestades (swaleys e hummockies), que se sobrepõem à seqüência de estuário/planície de marés com estruturas heterolíticas e com intercalações de conglomerados na base (NW). As areias de praia, por sua vez, são sobrepostas por seqüência granocrescente de conglomerados finos polimíticos com intercalações arenosas finas a grossas que, para o topo (SE), passam a conglomerados grossos polimíticos depositados subaereamente. As exposições restritas e descontínuas dificultaram observações seguras a respeito da proveniência dos detritos. Indicadores de paleocorrentes nos termos conglomeráticos (imbricação de clastos e estratificações cruzadas de pequeno porte) sugerem áreas-fonte a nordeste. Nos termos pelíticos predominam fluxos para nordeste/noroeste, sugerindo desenvolvimento de plataforma marinha a SW/SE.

Na Bacia de Pouso Alegre a base da seqüência (a NW) é constituída de conglomerados polimíticos subaéreos que, gradualmente, são intercalados por arenitos finos e pelitos retrabalhados por correntes de marés e ondas de tempestades. De modo gradacional, são sucedidos por pacote de metassiltitos calcíferos com intercalações arenosas a conglomeráticas finas, em lentes delgadas, que, paulatinamente, predominam para SE. Nos metassiltitos, os fluxos dirigem-se para NW, enquanto que nos metaconglomerados polimíticos, para S-SW. A passagem destes últimos para os metassiltitos calcíferos configura seqüência regressivotransgressiva. A sobreposição dos metassiltitos calcíferos por metarenitos finos a médios com intercalações conglomeráticas caracteriza, por sua vez, regressão com pulsos transgressivos (dunas barcanóides de costa-a-fora). Nos limites da borda sudeste atual com o embasamento predominam metaconglomerados, encerrando o pacote com seqüência provavelmente regressiva.

Na Bacia de Camarinha ciclicidade similar foi observada. Os termos conglomeráticos polimíticos de deposição subaérea ocupam a porção noroeste, base da bacia, onde predominam sobre os termos psamíticos e pelíticos. São sucedidos, para sudeste, por ritmitos silto-argilosos a arenosos depositados em ambiente marinho raso, acima do nível de ondas normais, não raro no limite inferior deste, o que pode ser evidenciado pela constante participação de marcas onduladas assimétricas nos termos pelíticos e, localmente, por ondas de tempestades. Intercalações cíclicas e rítmicas de termos arenosos a conglomeráticos e de conglomerados polimíticos seixosos marcam pulsos regressivo-transgressivos e/ou variações do aporte de detritos continentais, evidenciados em seqüências granocrescentes e granodecrescentes. O topo da seqüência, a SE, é coroado pelo predomínio de metarenitos com base conglomerática, sucedidos por metassiltitos 
com marcas onduladas assimétricas com cristas sub-retilíneas e, localmente, com estratificações cruzadas do tipo hummocky. Intercalações de conglomerados polimíticos são menos freqüentes, configurando fase transgressiva predominante.

Nas bacias do Samambaia e do Quatis, respectivamente, devido às escassas exposições rochosas e às dificuldades de acesso, as observações foram prejudicadas e, consequentemente, também, as interpretações paleoambientais.

$\mathrm{Na}$ Bacia de Cajamar, possível sedimentação carbonática plataformal de águas rasas caracteriza um máximo transgressivo. A presença de clastos fosfáticos em conglomerados de topo da bacia (Hachiro \& Santoro 1996) aponta para condições globais de mar alto, o que, eventualmente, pode ter ocorrido após um evento glacial seguido de fenômenos de ressurgência oceânica, situação que se assemelha ao ocorrido na Bacia de Corumbá, com níveis fosfogênicos nas formações Bocaina e Tamengo (Boggiani 1998). Entretanto, os clastos fosfáticos da Bacia de Cajamar encontram-se em depósitos retrabalhados (conglomerados), representativos de fase regressiva que se sobrepõe à fase transgressiva, representada pelos carbonatos, o que não ocorre no Grupo Corumbá. De todo modo, é plausível supor que a sedimentação da Bacia de Cajamar ocorreu após a glaciação Varanger (625-580 Ma), como proposto para o Grupo Corumbá (Boggiani 1998).

Coerente com as características acima descritas para o preenchimento das bacias da transição, é possível advogar que a sedimentação marinha tenha ocorrido sob condições de um mar epicontinental que, provavelmente, avançou sobre regiões mais baixas (subsidentes?) de um continente em fase de consolidação. Os caminhos preferenciais para a penetração das águas oceânicas, ao que parece, foram as regiões de faixas móveis. Estas, encontravam-se em estágio de relativa reativação, em conseqüência do resfriamento crustal pós-orogênico que impunha ao grande emaranhado de blocos crustais e a essas faixas novos rearranjos, requeridos pela constante necessidade do reequilíbrio geodinâmico. Entretanto, as condições gerais da crosta continental eram de crosta espessada, graças às sucessivas colagens de blocos e terrenos que anteriormente aportaram ao Gondwana Ocidental. Por outro lado, considerando-se o conteúdo litoclástico dos depósitos (principalmente clastos de granitos e granitóides de arcos magmáticos brasilianos), supõem-se que as calhas deposicionais assentavam-se sobre terrenos previamente soerguidos, ou ainda em fase de soerguimento, mas que foram decapados pela erosão até profundidades consideráveis, que poderiam variar entre 5 a $10 \mathrm{~km}$, onde se situariam os processos de granitogênese. Desse modo, justifica-se a inexistência de quaisquer vestígios de crostas oceânicas envolvidas na evolução dessas bacias. Por outro lado, também, há que ser 
considerado que as condições globais do planeta eram de mar alto, pós glaciação Varanger (625$580 \mathrm{Ma}$ ), e com temperaturas em elevação. Consequentemente, é possível supor que as entradas de águas oceânicas continente adentro podem ter sido propiciadas pela conjunção de subsidências relativas no interior continental, principalmente ao longo das faixas móveis, e pela subida global do nível de mar.

\subsection{Evolução das bacias da transição no contexto do Gondwana Ocidental}

As similaridades estratigráficas e, em parte, bioestratigráficas apontam uma provável cogeneticidade das bacias da transição do Estado de São Paulo e adjacências. Os dados isotópicos $\mathrm{K}-\mathrm{Ar}$ e U/Pb delimitam intervalo para a sedimentação compreendido entre 606 e 530 Ma, aproximadamente. A presença de Cloudina riemkeae nas bacias de Eleutério, do Pico de Itapeva e, provavelmente, na de Cajamar refina, provisoriamente, tal intervalo para 570-545 Ma, reforçando hipótese da contemporaneidade de sedimentação nas mesmas.

Ambientes de sedimentação continentais subaéreos, situados a noroeste/nordeste, transicionais a ambientes marinhos rasos, estuarinos e/ou de planícies de marés e de praias, e controlados por đeposição de deltas de granulação grossa (sentido McPherson et al. 1987), são comuns a todas elas, excetuando-se a Bacia de Cajamar. Nesta última, provavelmente a sedimentação carbonática plataformal de águas rasas predominou, e a ocorrência de clastos fosfáticos na unidade conglomerática superior aponta para uma conexão oceânica ampla, em escala global, com as bacias marginais dos crátons do Amazonas (Corumbá/Cuiabá), do Congo/Kalahari (Nama) e do Rio de la Plata (Arroyo del Soldado). A participação de eventos de tempestades e de planícies de marés nas bacias terrígenas, indicam, também, a existência de um oceano mais amplo e aberto em conexão direta com os embaciamentos em questão, o que poderia remodelar as hipóteses de simples embaiamentos e/ou engolfamentos locais, como sugeridas por Teixeira (1996) e Riccomini \& Coimbra (1996), respectivamente, para as bacias de Eleutério e do Pico de Itapeva. Reforça, também, tal argumento a presença de microfósseis com reconhecida expressão global, como Cloudina riemkeae, descritos nos grupos Corumbá (MS), Nama (Namíbia) e Arroyo del Soldado (Uruguai).

Considerando-se os aspectos acima relatados, torna-se plausível supor uma antiga conexão entre os oceanos Adamastor e Brazilides, que acolheram as bacias da transição em estudo e aquelas da Namíbia, Uruguai e Mato Grosso do Sul. 
A hipótese de uma evolução com deposição em bacia do tipo pull-apart para as bacias em estudo, como aventada por Riccomini (1993), para a Bacia do Pico de Itapeva, e por Teixeira (1995), para a Bacia de Eleutério, não foi confirmada. Do mesmo modo, a hipótese de bacia do tipo foreland de retro-arco sugerida por Soares (1987), entre outros, para a Bacia de Camarinha aparentemente não se sustenta, tendo em vista posição conflitante das áreas-fonte desta (situadas a NW) com o suposto arco (orógeno) situado a SE, conforme o referido autor. Ademais, o estilo estrutural e deposicional, além do seu conteúdo sedimentar pobre em clastos das regiões supostamente soerguidas, não se coadunam com aquele característico de uma bacia do tipo foreland. No caso das supostas bacias pull-apart, faltar-lhes-ia as feições estruturais típicas, como dobramentos en echéllon, variações sensíveis de áreas-fonte, migração de depocentros, constantes justaposições de fácies díspares, etc. O contorno romboédrico de seus limites atuais é, provavelmente, apenas uma feição adquirida durante a fase de inversão e encurtamento dessas bacias. O retalhamento da Bacia de Eleutério por falhamentos tardios, posteriores à sua inversão, induz supor a existência de disparidades estratigráficas e diversificação de fácies sedimentares, que seriam características das bacias de afastamento. $\mathrm{O}$ mesmo já não ocorre nas demais bacias analisadas, onde a justaposição de unidades sedimentares díspares praticamente inexiste e, portanto, as passagens entre as seqüências deposicionais são predominantemente gradacionais, inexistindo evidências estruturais e sedimentares de deformações sindeposicionais. Por outro lado, a participação de águas marinhas durante preenchimento de uma bacia pull-apart, em ambiente de espessamento crustal, ocorreria nos seus estágios de máxima evolução, o que implicaria necessariamente em episódios de vulcanismo em seu assoalho (Mann et al. 1983), o que não ocorre em quaisquer das bacias da transição analisadas.

Mas, não pode ser desprezado, entretanto, que para a origem e evolução das bacias em questão, houve a participação importante das zonas de cisalhamentos empinadas e associadas a movimentos predominantemente laterais (strike slip faults), o que poderia caracterizá-las como bacias extensionais associadas às zonas transcorrentes (strike slip basins), provavelmente associadas às resultantes extensionais, uma vez que no pacote deposicional ausentam-se as feições que caracterizariam dinâmicas convergentes, como cavalgamentos e empurrões sindeposicionais. A cronologia e a quantificação dos eventos nessas bacias não foram possíveis de serem obtidos. O que houve, provavelmente, foi a conjugação de movimentos laterais, provocados pelo rearranjo dos blocos crustais recém-amalgamados e em resfriamento com o final dos eventos de granitogênese, com outros eminentemente divergentes (extensionais) associados com a dinâmica intraplacas do Gondwana Ocidental. 
O contexto evolutivo do Gondwana Ocidental remonta os primórdios do Neoproterozóico, quando ocorreu a fragmentação do suposto Supercontinente Rodínia (designação dada por McMenamin \& McMenamin 1990, apud Rogers 1996), que por volta de 1,0 Ga reunia em posições equatoriais e ao redor da Laurentia (núcleo ancestral do continente norte-americano) a maioria dos blocos e fragmentos continentais do planeta. A sua fragmentação iniciou-se entre 750-700 Ma possibilitando a abertura de vários oceanos, entre os quais os oceanos Adamastor (Hartnady et al. 1985) que separava os terrenos que se aglutinavam ao redor dos crátons do Congo e Kalahari, a leste, daqueles que se aglutinavam ao redor dos crátons do São Francisco, Rio de la Plata/Paraná, a oeste, estendendo sua águas desde posições próximas do pólo sul até aquelas próximas do equador (latitudes de $20^{\circ} \mathrm{S}$ ). Ocidentalmente ao Oceano Adamastor e para além dos crátons do São Francisco, do Rio de la Plata/Paraná, estendia-se o Oceano Brazilides (Dalziel 1997), cuja abertura ocorreu graças à separação dos crátons acima referidos com o Cráton do Amazonas. Nas regiões mais próximas do pólo sul associou-se a glaciação Varanger (entre 625-580 Ma), cujos registros são encontrados na Formação Puga, unidade sotoposta ao Grupo Corumbá. Com o continuar da fragmentação desse supercontinente, inicia-se a fase rift-to-drif do continente Amazônico, com relação ao continente São Francisco, desenvolvendo-se em suas margens orientais sedimentação plataformal em bacia de margem passiva do tipo Atlântico (Boggiani 1998). Enquanto isso, o lado oriental do Cráton do São Francisco é palco de intensas granitogêneses acompanhadas da docagem de vários terrenos com consumo da crosta oceânica da Bacia Adamastor, ao lado da convergência do Cráton do Congo/Kalahari. Dalziel (1997) advogou que após essa fragmentação do Rodínia os continentes se reencontraram novamente, de modo efềmero, nos finais do Neoproterozóico (545-515 Ma), quando vieram constituir o Supercontinente Pannotia ("todos os terrenos ao sul", conceito original de Stump 1987, apud Brito Neves 1999). É possível que o início da inversão e encurtamento dessas bacias esteja associado com essa fase de convergencia global de blocos e terrenos crustais.

Num cenário desenvolvido, grosso modo, entre 570-540 Ma, que pode ser vislumbrado esquematicamente na Figura 6.4.1, compilada e modificada de Campos Neto (2000), desenvolveram-se as bacias da transição, terrígenas. Situadas em regiões de topografia relativamente baixas, entre as terras altas formadas pelos arcos magmáticos e demais blocos que se adicionaram às bordas orientais do Cráton do São Francisco e o Bloco Paraná, a oeste. As regiões baixas sobre as faixas móveis eram atingidas pelas águas do Oceano Brazilides. O Bloco Paraná justapôs suas porções setentrionais àquelas meridionais do Cráton do São Francisco durante a Orogênese Tocantins (630 Ma), quando ocorreu o fechamento do Oceano Goianides 


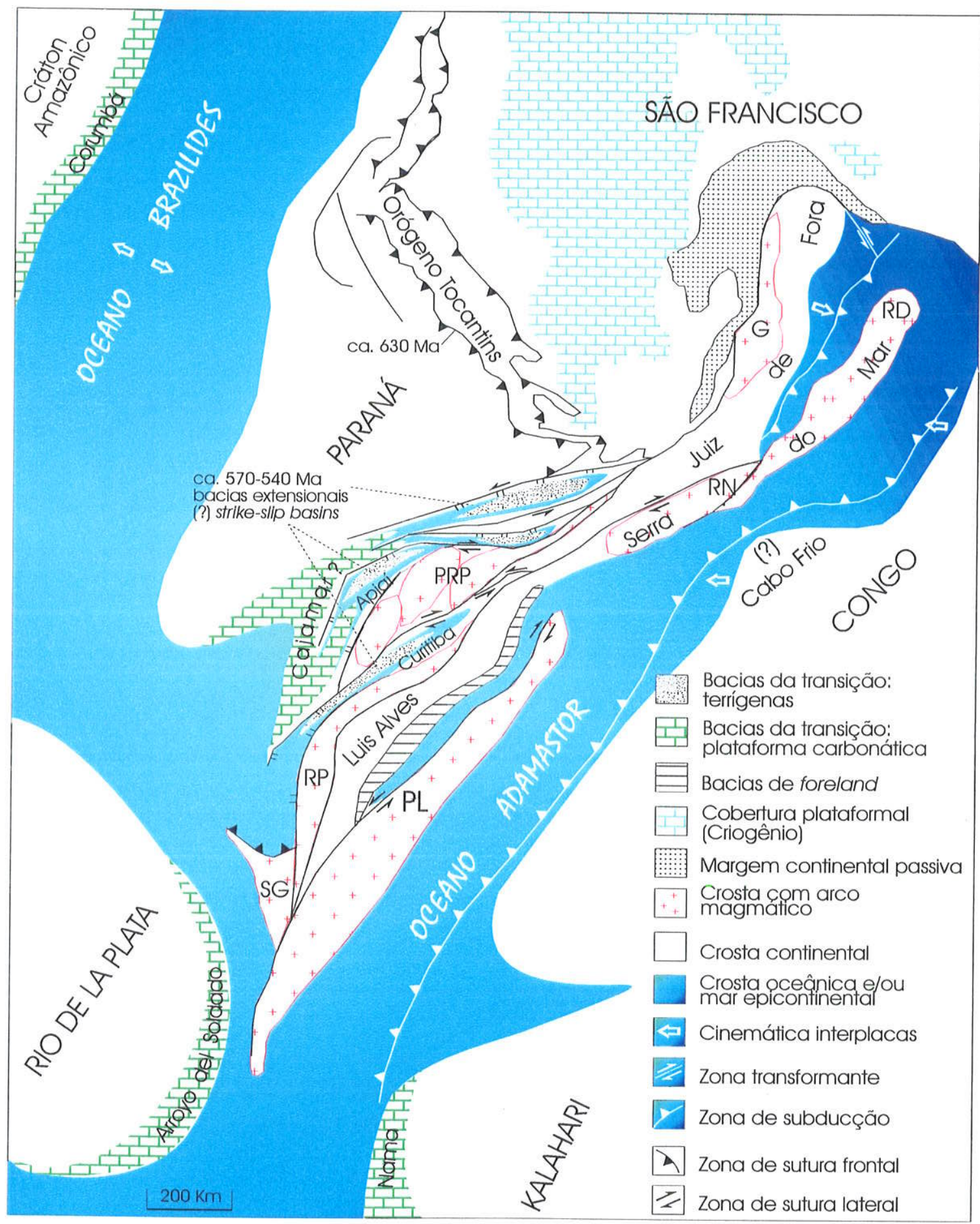

Figura 6.4.1 - Contexto geotectônico e paleogeográfico de parte do Gondwana Ocidental (ca. 570-540 Ma) para a evolução das bacias da transição Proterozóico-Fanerozóico. Arco de Ilha: SG - São Gabriel (700 Ma), Arcos Magmáticos: RN - Rio Negro (630 Ma), PL - Pelotas (630-610 Ma), RP - Rio Pien (615 Ma), PRP Paranapiacaba (610-570 Ma), RD - Rio Doce (590-570 Ma), Arco Plutônico: G - Galiléia (600-580 Ma). Compilado e modificado de Campos Neto (2000). 
(Brito Neves et al. 1999). Ao sul do Bloco Paraná, para além das águas provavelmente rasas do Oceano Brazilides, estendia-se o Cráton do Rio de la Plata, separado dos terrenos acrescidos ao Bloco São Gabriel pelas águas do Oceano Adamastor, em região onde este oceano se conectava com o Oceano Brazilides. A hipótese de tal conexão encontra respaldo, principalmente, na ocorrência do microfóssil Cloudina riemkeae nas bacias do Nama, na Namíbia, desenvolvida às margens ocidentais do Cráton do Kalahari; na Bacia do Arroyo del Soldado, desenvolvida na margem oriental do Cráton do Rio de la Plata; na Bacia de Corumbá, desenvolvida na margem oriental do Cráton Amazônico; e, finalmente, nas bacias da transição em questão (como de Eleutério, de Cajamar e do Pico de Itapeva?). É também respaldada pelas assembléias de acritarcas, como Symplassosphaeridium sp. e Soldadophycus major, e o foraminífero Titanotheca coimbrae, comuns, pelo menos, às bacias do Arroyo del Soldado, de Pouso Alegre, de Cajamar e do Pico de Itapeva.

A sedimentação nessas bacias ocorreu provavelmente entre $570-540 \mathrm{Ma}$, baseando-se principalmente na ocorrência e no espectro de existência do microfóssil Cloudina riemkeae (565$543 \mathrm{Ma})$ de importância crono e bioestratigráfica internacionalmente reconhecida. De todo modo, o intervalo para a sedimentação não avançaria em muito os limites inferiores a $600 \mathrm{Ma} \mathrm{e}$ aqueles superiores aos $530 \mathrm{Ma}$, baseando-se nos dados geocronológicos locais e regionais disponíveis, como já argumentados. Este último limite superior marcaria, quase que irrefutavelmente, o início da inversão e encurtamento dessas bacias, cujos processos puderam ter se estendido até por volta de $500 \mathrm{Ma}$, no Cambro-Ordoviciano, quando do fechamento final do Oceano Adamastor com a orogenia Búzios (Schmitt 1999) ou Cabo Frio (Brito Neves et al. 1999 e Campos Neto 2000), em que os crátons do Congo e do São Francisco convergiram entre si. Mais ao sul, concomitantemente à orogenia Cabo Frio, ocorria a convergência entre os crátons do Rio de la Plata e do Kalahari, justapondo os terrenos do Cinturão Dom Feliciano aos terrenos Nico Pérez, onde se desenvolvia a deposição do Grupo Arroyo del Soldado (Gaucher \& Sprechmann 1999 e Gaucher 2000). Ao mesmo tempo, o Cráton Amazônico convergia para o Cráton do São Francisco, cerrando o Oceano Brazilides, o que ocorreu acompanhado de significativos dobramentos nas porções distais dos depósitos das bacias de Corumbá/Cuiabá (Boggiani 1998 e Alvarenga et al. 2000), seguidos pelas intrusões pós-tectônicas do Granito São Vicente, ao redor de $500 \mathrm{Ma}$ (Almeida \& Mantovani 1975). 


\section{CONSIDERAÇÕES FINAIS}

A análise das bacias da transição Proterozóico-Fanerozóico do Estado de São Paulo e adjacências aqui realizada, permitiu apontar que existem grandes similaridades estratigráficas, sedimentológicas e estruturais entre elas, tornando-se possível o estabelecimento de correlações e ainda, de forma inicial, correlacioná-las com outras distribuídas no continente sul-americano e no oeste africano.

A conjugação de dados geocronológicos e paleontológicos disponíveis, ainda que preliminares, apontaram para um provável intervalo para a sedimentação situado entre 570-540 Ma, baseando-se na ocorrência do microfóssil Cloudina riemkeae em algumas dessas bacias, intervalo esse que estaria compreendido em outro mais amplo, obtido a partir de análises geocronológicas neste trabalho e por comparações com outros constantes da literatura, a saber: 606-600 Ma - idade U/Pb pelo método SHRIMP de seixo de riólito da Bacia de Eleutério e idade aproximada da principal granitogênese brasiliana; e $530 \mathrm{Ma}$ - idade obtida pelo método $\mathrm{K}$ Ar em seixo de riólito, também, da Bacia Eleutério e em metassiltitos da Bacia de Pouso Alegre, e que marca evento metamórfico de expressão continental associado com os últimos estágios orogenéticos de consolidação do Gondwana Ocidental e fechamento dos oceanos Adamastor e Brazilides.

As feições estratigráficas e sedimentológicas das bacias, por sua vez, permitiram reconhecer que os pacotes deposicionais abrangem, invariavelmente, sedimentação continental em leques aluviais que transicionam para ambientes marinhos rasos, provavelmente com a participação de construções deltaicas de granulometrias grossas (sentido McPherson et al. 1987) e sujeitas ao retrabalhamento por correntes litorâneas, ondas normais e, episodicamente, por ondas de tempestades. Excetua-se a Bacia de Cajamar, onde a sedimentação carbonática ocorreu em ambiente plataformal raso, sem evidências contundentes da participação de processos continentais subaéreos. A sedimentação carbonática nesta bacia marcaria um máximo transgressivo que, talvez, possa ser correlacionado com os máximos transgressivos das bacias de Eleutério, Pouso Alegre, Pico de Itapeva e Camarinha. Entretanto, acredita-se, que apenas com o avanço dos estudos micropaleontológicos em curso poder-se-á obter subsídios bioestratigráficos e cronoestratigráficos que o comprovem. A análise de fácies sedimentares e de paleocorrentes apontaram para áreas-fonte situadas principalmente em regiões setentrionais às bacias, o que situaria em posições meridionais o corpo d'água marinho. A composição dos litoclastos indica contribuições de áreas-fonte predominantemente ígneas (graníticas) ou metamórficas de médio a 
alto grau (orto e paragnaisses) constituintes do embasamento próximo. Excepcionalmente, nas bacias de Camarinha e do Samambaia predominam clastos de metassedimentos de baixo grau metamórfico sobre os de granitóides, refletindo particularidades do embasamento que as acolheram. Mas, em todos os casos os processos de ressedimentação ou reciclagem estão bem evidenciados. Os dados geoquímicos obtidos apontam também para uma importante contribuição de clastos de áreas-fonte ígneas, refletida nas constantes anomalias negativas de Eu. Esses clastos foram retrabalhados sofrendo o fracionamento granulométrico e, posteriormente, metamorfizados em grau muito baixo, durante a inversão e encurtamento das bacias, alterando significativamente as razões $\mathrm{Rb} / \mathrm{Sr}$.

As feições estruturais, aliadas às características estratigráficas, mostraram-se insuficientes para se traçar um modelo genético das bacias. Apenas para a fase de inversão e encurtamento é possível advogar que houve a participação predominante de binários de esforços máximos compressivos dirigidos de posições próximas de E-W, que imprimiram movimentações predominantemente destrogiras às zonas de cisalhamentos, provocando o adernamento, ora para NW e ora para SE, dos pacotes deposicionais das bacias, o que foi acompanhado pela geração de uma foliação metamórfica de grau muito baixo. Acredita-se que as feições aproximadamente romboédricas que poderiam caracterizar embaciamentos do tipo pull-apart sejam apenas secundárias e adquiridas durante a fase metamórfica, pós-sedimentar. Entretanto, deve ser considerado que as bacias da transição se instalaram após os estágios de orogênese, quando predominava movimentos de reajustes entre blocos crustais em fase de resfriamento e que esses movimentos eram predominantemente laterais e ao longo de zonas de cisalhamentos com planos empinados que, provavelmente, tiveram grande importância para a geração dessas bacias. Desse modo, elas poderiam ser consideradas como bacias extensionais associadas às zonas transcorrentes (strike slip basins), cuja tafrogênese estará ainda para ser delineada com detalhes em trabalhos futuros.

Os ensaios de correlações realizados com os dados obtidos neste estudo e com aqueles disponíveis na literatura abordando bacias similares, acrescidos das informações, também advindas da literatura, sobre a evolução do embasamento, permitiram contextualizá-las no tempo e espaço do Gondwana Ocidental. As informações paleontológicas e geocronológicas, além das características estratigráficas e estruturais, são sugestivas de que as bacias da transição em questão evoluíram às margens de um mar epicontinental suprido pelas águas do Oceano Brazilides que avançavam sobre o Bloco do Paraná até atingir regiões de baixos topográficos do continente que, grosso modo, coincidiam com as regiões de faixas móveis. A deposição teve 
início, provavelmente, após o evento glacial Varanger (680-625 Ma), quando o nível global dos oceanos e as temperaturas encontravam-se em ascenção. O Oceano Brazilides iniciou sua expansão após essa fase glacial consubstanciando a separação dos continentes Amazônico/Laurentia/Pampea dos continentes São Francisco/Paraná/Rio de la Plata. Do lado oeste do Oceano Brazilides, na margem oriental do Cráton Amazônico desenvolveu-se sedimentação plataformal dos grupos Corumbá/Cuiabá. No Grupo Corumbá, a ocorrência de Cloudina riemkeae indica contemporaneidade, pelo menos em parte, da sedimentação com as bacias da transição em questão, além de apontar a conexão entre as águas oceânicas. As mesmas correlações puderam ser apontadas com relação aos depósitos do Grupo Arroyo del Soldado, no Uruguai, cuja sedimentação ocorreu nas margens orientais do Cráton do Rio de la Plata, banhadas pelas águas do Oceano Adamastor que, contrariamente ao que ocorria com o Oceano Brazilides, encontrava-se em fase de constante fechamento, à medida que os crátons do Congo/Kalahari convergiam em direção aos crátons do São Francisco/Paraná/Rio de la Plata. Nesta bacia foram identificados além da Cloudina, acritarcas também encontradiços nas bacias da transição em questão, o que apontaria uma relativa contemporaneidade na sedimentação e provável conexão entre as águas oceânicas do Adamastor com o Brazilides, que ocorreria nas porções do extremo sul do Bloco do Paraná. Do mesmo modo, do lado ocidental do Cráton do Kalahari, a presença de Cloudina riemkeae nos depósitos do Grupo Nama (Namíbia), além de toda a fauna ediacariana, reforçariam as hipóteses de uma conexão marinha ampla e contemporaneidade na sedimentação.

$\mathrm{E}$, finalmente, deve ser ressaltado que, methor compreensão sobre a evolução das bacias da transição Proterozóico-Fanerozóico do Estado de São Paulo e adjacências advirá à medida que evoluam os conhecimentos sobre o seu potencial fossilifero e sobre as técnicas e os métodos de datações radiométricas de metassedimentos, aliados à geoquímica de rocha. Mas, fundamentalmente, essa melhor compreensão advirá à medida que os aspectos estratigráficos e tectônicos das bacias sejam mais conhecidos e ampliados, o que dependerá de melhores exposições rochosas para as observações e de detalhamentos geológicos do embasamento que, inclusive, contemplem a discriminação de possíveis remanescentes, ainda desconhecidos, destas bacias. 


\section{REFERÊNCIAS BIBLIOGRÁFICAS}

Almeida, F.F.M. de 1964. Fundamentos geológicos do relevo paulista. São Paulo, Inst. Geogr. Geol., 169-263 (Boletim 41)

Almeida, F.F.M. de 1967. Origem e evolução da plataforma brasileira, Rio de Janeiro, Div. Geol. Min - DNPM, 1-36 (Boletim 241)

Almeida, F.F.M. de 1969. Diferenciação tectônica da plataforma brasileira. In: SBG, Congr. Bras. Geol., 23, Salvador, Anais, 29-46

Almeida, F.F.M. de \& Mantovani, M.S.M. 1975. Geologia e geocronologia do granito de São Vicente, Mato Grosso. An. Acad. Bras. Ci. 47: 451-458

Almeida, F.F.M. de; Hasuy, Y.; Ponçano, W.L.; Dantas, A.S.L.; Carneiro, C.D.R.; Melo, M.S. de; Bistrichi, C.A. 1981. Mapa Geológico do Estado de São Paulo, escala 1:500.000. Nota Explicativa. Inst. Pesq. Tecn. Est. São Paulo, Div. Min. Geol. Aplic., Publicação n ${ }^{\circ}$ 1184, São Paulo

Alvarenga, C.J.S.; Moura, C.A.V.; Gorayeb, P.S.S.; Abreu, F.A.M. 2000. Paraguay and Araguaia belts. . In: Cordani et al. (eds.) Tectonic evolution of South America. Rio de Janeiro, $31^{\text {st }}$ International Geological Gongress, 183-193

Amieux, P. 1982. La Cathodoluminescence: méthode d'étude sédimentologique des carbonates. Bull. Centres Rech. Explor.-Prod. Elf-Aquitaine, 6 (2):437-483

Artur, A.C. 1980. Rochas metamórficas dos arredores de Itapira-SP. Inst. de Geociências, Universidade de São Paulo, São Paulo, Dissertação de Mestrado, 193p.

Artur, A.C. 1988. Evolução policíclica da infra-estrutura da porção sul do Estado de Minas Gerais e regiões adjacentes do Estado de São Paulo. Inst. de Geociências, Universidade de São Paulo, São Paulo, Tese de Doutoramento, 231p.

Artur, A.C.; Wernick, E.; Fiori, A.P. 1981. Estruturas redobradas nos arredores de Itapira (SP). In: SBG, Simp. Reg. Geol., 3, Curitiba, Atas, 1: 252-261

Artur, A.C.; Wernick, E.; Kawashita, K. 1979. Dobramentos superimpostos na região de Itapira (SP): Caracterização e cronologia. In: SBG, Simp. Reg. Geol., 2, Rio Claro, Atas, 1: 59-70

Baldis, B.A. 1992. Marco estructural de las cuencas del Paleozoico Inferior sudamericano en su contexto gondwánico. In: MARCO et al. (eds.) Paleozoico Inferior de Ibero-América, Extremadura, Univ. Extremadura, 1-19

Basei, M.A.S. \& Brito Neves, B.B. de 1992. Características geológicas da transição Proterozóico-Fanerozóico no Brasil. In: Marco et al. (eds.) Paleozoico Inferior de IberoAmérica, Extremadura, Univ. Extremadura, 331-342

Basei, M.A.S.; Siga Jr., O.; Machiavelli, A.; Mancini, F. 1992. Evolução tectônica dos terrenos entre os cinturões Ribeira e Dom Feliciano (PR-SC). Rev. Bras. Geoc., 22 (2): 216-221 
Basei, M.A.S.; Kawashita, K.; Siga Júnior, O. 1987. Idade, características litoestratigráficas e estruturais do Grupo Itajaí, SC. In: South Brazilian Congress of Geology, 3, Curitiba, PR. 11: $93-106$

Basei, M.A.S.; Siga Jr., O.; Cordani, U.G.; Sato, K.; Lima, P.S. 1999. The magmatism of the Itajaí Basin, SC - Southern Brazil and its importance to define the ProterozoicPhanerozoic limit. In: South American Symposium on Isotope Geology, II, Argentina, Actas, 287-290

Batchelor, R.A. \& Bowden, P. 1985. Petrogenetic interpretation of granitoid rock series using multicationic parameters. Chem. Geol., 48: 43-55

Berthé, D.; Choukroune, P.; Jegouzo, P. 1979. Orthogneiss, mylonite and non coaxial deformation of granites: the example of the South Armorican Shear Zone. J. Struc. Geol., 1 (1): $31-42$

Bhatia, M. R. 1983. Plate tectonics and geochemical composition of sandstones. J. Geol., 91: $611-627$

Bistrichi, C.A.; Carneiro, C.D.R.; Dantas, A.S.L.; Ponçano, W.L.; Campanha, G.A. da C.; Nagata, N.; Almeida, M.A. de; Stein, D.P.; Melo, M.S. de; Cremonini, O.A.; Hasui, Y.; Almeida, F.F.M. de. 1981. Mapa geológico do Estado de São Paulo, escala 1:500.000. São Paulo, IPT, v.2, Monografias, 6, 126p.

Blatt, H.; Middleton, G.; Murray, R. 1980. Origin of Sedimentary Rocks. 2 ed., New Jersey, Prentice-Hall, 782p.

Boggiani, P.C. 1998. Análise estratigráfica da Bacia Corumbá (Neoproterozóico) - Mato Grosso do Sul. Inst. de Geociências, Universidade de São Paulo, São Paulo, Tese de Doutoramento, $181 \mathrm{p}$.

Bohor, B.F. \& Triplehorn, D.M. 1993. Tonsteins: altered volcanic-ash layers in coal-bearing sequences. Geol. Soc. Am., 44p. (Special Paper 285)

Braun, O.P.G. 1968. Contribuição à estratigrafia do Grupo Bambuí. In: SBG, Congr. Bras. Geol., 22. Belo Horizonte, Anais, 155-166

Brito Neves, B.B. 1999. América do Sul: quatro fusões, quatro fissões e o processo acrescionário andino. Rev. Bras. Geociências. 29 (3): 379-392

Brito Neves, B.B.; Campos Neto, M. da C. \& Fuck, R.A. 1999. From Rodinia to Western Gondwana: An approach to the Brasiliano-Pan African Cycle and orogenic collage. Episodes, 22 (3): 155-166

Bull, W. B. 1963. Alluvial fan deposits in Western Fresno County, California. J. Geol., 71: 243251

Campanha, G.A. da C. 1991. Tectônica proterozóica no Alto e Médio Vale do Ribeira, estados de São Paulo e Paraná. Inst. de Geociências, Universidade de São Paulo, São Paulo, Tese de Doutoramento, 296p.

Campanha, G.A. da C. \& Sadowski, G.R. 1999. Tectonics of the southern portion of the Ribeira Belt (Apiaí Domain). Precambrian Research, 98: 31-51 
Campanha, G.A. da C. \& Teixeira, A.L. 1986. Nota sobre a ocorrência de um novo depósito molássico de possível idade eopaleozóica no Estado de São Paulo: Formação Quatis. An. Acad. Bras. Ci., 58 (4): 595

Campanha, G.A. da C.; Gimenez Filho, A.; Caetano, S.L.V.; Pires, F.A.; Dantas. A.S.L.; Teixeira, A.L.; Dehira, L.K. 1985. Geologia das folhas Iporanga (SG-22-X-B-V-2) e Gruta do Diabo (SG-22-X-B-VI-1), Estado de São Paulo. SICCT/PRÓ-MINÉRIO. Relatório IPT $\mathrm{n}^{\mathrm{o}}$. 22.352, v.1, 206p.

Campanha, G.A. da; Machado Jr., D. de L.; Nagata, N.; Dantas, A.S.L.; Ens, H.H.; Gimenez Filho, A.; Bistrichi, C.A.; Ferreira, F.J.F.; Monma, R.; Echebehere, M.L. de C.; Rondinelli, D.; Stein, D.P.; Maeyama, O.; Dehira, L.K.; Bordignon, J.L. 1988. Avaliação preliminar da geologia das folhas (em 1:50.000) Taquaral, Mina do Espírito Santo, Ribeirão Itacolomi, Serra do Aboboral, Jacupiranga (Eldorado Paulista), Rio Guaraú (Barra do Azeite), Rio Turvo (Serra do Aleixo) - Vale do Ribeira, SP. SCT/PRÓMINÉRIO. Relatório IPT n ${ }^{\circ} .26863,4 v s ., 334$ p.

Campanha, G.A. da C.; Fernandes, L.A.; Gimenez Filho, A. 1982. Mapeamento geológico na escala 1:50.000 das folhas Mogi-Guaçu (parte correspondente ao embasamento cristalino) e Águas de Lindóia (parte correspondente ao Estado de São Paulo). Rel. IPT $\mathrm{n}^{\circ} .17 .446$

Campos Neto, M. da C. 1991. A porção ocidental da Faixa Alto Rio Grande m ensaio de evolução tectônica. Inst. de Geociências, Universidade de São Paulo, São Paulo, Tese Doutoramento, $210 \mathrm{p}$.

Campos Neto, M. da C. 2000. Orogenic systems from southwestern Gondwana. An approach to Brasiliano-Pan African Cycle and orogenic collage in southeastern Brazil. In: Cordani et al. (eds.) Tectonic evolution of South America. Rio de Janeiro, $31^{\text {st }}$ International Geological Gongress, 335-365

Campos Neto, M. da C,; Figueiredo, M.H. 1995. The Rio Doce Orogeny, Southeastern Brazil. Journal of South American Earth Sciences, 8 (2): 143-162

Caputo, M.V. \& Crowell, J.C. 1985. Migration of glacial centers across Gondwana during Paleozoic Era. Geol. Soc. Amer. Bull., 96 (8): 1020-1036

Cavalcante, J.C.; Cunha, H.C. da S.; Chieregati, L.A.; Kaefer, L.Q.; Rocha, J.M. da; Daitx, E. C.; Coutinho, M.G. da N.; Yamamoto, K.; Drumond, J.B.V.; Rosa, D.B.; Ramalho, R. 1979. Projeto Sapucaí (Relatório Final de Geologia). Brasília, DNPM/CPRM. 299p. (Série Geologia, 5; Seção Geologia Básica, 2)

Choudhuri, A.; Ebert, H.; Winters, A.A.M. 1978. Os metassedimentos e paragnaisses da região norte de Pouso Alegre, sul de Minas Gerais. In: SBG, Congr. Bras. Geol., 30, Recife, Anais, 1: 69-82

Ciguel, J.H.G.; Góis, J.R. de; Aceñolaza, F.G. 1992. Ocorrência de icnofósseis em depósitos molássicos da Formação Camarinha (Neoproterozóico III-Cambriano Inferior), no Estado do Paraná, Brasil. In: Aceñolaza \& Esteban (eds.) El Paleozoico Inferior en Latinoamerica y la genesis del Gondwana. Univ. Tucumán, Serie Correlacion Geologica $\mathrm{N}^{\circ} 9,157-158$ 
Coimbra, A.M.; Góes, A.M.; Hachiro, J.; Sant'anna, L.G.; Herlmeister Junior, Z.; Cabral Junior, M.; Moraes, M.C. de; Stefani, F.L.; Vieira, P.C. 1992. Proposta de classificação integrada de rochas sedimentares clásticas. In: CONGR. BRAS. GEOL., 37. São Paulo, 1992. Bol. Res. Exp...São Paulo, SBG, v. 2., p. 419-421

Collinson, J.D. \& Thompson, D.B. 1989. Sedimentary Structures. London Unwin Hyman, 207 p.

Cordani, U.G.; Brito Neves, B.B. de; Fuck, R.A.; Porto, R.; Thomaz Filho, A.; Cunha, F.M.B. da 1984. Estudo preliminar de integração do Pré-Cambriano com os eventos tectônicos das bacias sedimentares brasileiras. Rio de Janeiro, PETROBRÁS (CENPES/SINTEP), 70 p. (Série Ciência-Técnica-Petróleo. Seção: Exploração de Petróleo. Publ. no 15)

Cordani, U.G.; Basei, M.A.S.; Siga Júnior, O.; Nutman, A. 1999. Idades U-Pb (SHRIMP) de rochas vulcânicas das bacias de Campo Alegre, Itajaí e Castro (SC e PR). An. Acad. Bras. Ci., 71 (4): 835

Dalziel, I.W.D. 1997. Neoproterozoic-Proterozoic geography and tectonics: review, hypothesis, environmental speculation. GSA Bulletin, 109(1): 16-42

Ebert, H. 1968. Ocorrência de fácies granulítica no sul de Minas e em áreas adjacentes, em dependência da estrutura orogênica: hipótese sobre sua origem. An. Acad. Bras. Ci., Rio de Janeiro, 40 (supl.): 215-229

Ebert, H. 1971. Os Paraibides entre São João del Rei, Minas Gerais e Itapira, São Paulo e a bifurcação entre Paraibides e Araxaídes. In: SBG, Congr. Bras. Geol., 25, São Paulo, Resumo das Comunicações, 177-178 (Boletim Especial, 1)

Ebert, H. 1974. O Grupo Eleutério e a Falha de Jacutinga, nordeste do Estado de São Paulo. In: SBG, Congr. Bras. Geol., 28, Porto Alegre, Resumo das Comunicaçóes, 726-730 (Boletim Especial, 1)

Ebert, H. 1984 (in memoriam). Os Paraibides entre São João del Rei (MG) e Itapira (SP) e a bifurcação entre Paraibides e Araxaídes. São Paulo, SBG/Núcleo São Paulo, 72-103 (Publicação $\mathrm{n}^{\circ} 12$ )

Fiori, A.P.; Landim, P.M.B.; Bettencourt, J.S. 1981. Geologia da região de Pouso AlegreMachado: análise geométrica de dobramentos superpostos. Rev. Bras. Geoc., 11 (1): 2235

Fiori, A.P.; Wernick, E.; Bettencourt, J.S. 1978. Evolução policíclica na região nordeste do Estado de São Paulo e áreas vizinhas do Estado de Minas Gerais. In: SBG, Congr. Bras. Geol., 30, Recife, Anais; 1: 303-320

Floyd, P.A.; Winchester, J.A.; Park, R.G. 1989. Geochemistry and tectonic setting of Lewisian clastic metasediments from the Early Proterozoic Loch Maree Group of Gairloch, NW Scotland. Precambrian Research, 45: 203-214

Frascá, M.H.B. de O. 1992. Petrografia e geoquímica de rochas carbonáticas pré-cambrianas do Estado de São Paulo. Inst. de Geocências, Universidade de São Paulo, São Paulo, Dissertação de Mestrado, $168 \mathrm{p}$.

Fuck, R.A. 1966. Nota Explicativa da Folha geológica de Quero-Quero. Univ. Fed. do Paraná, 21p. (Boletim 19) 
Fuck, R.A.; Marini, O.J.; Trein, E. 1967. A Formação Guaratubinha. In: BIGARELLA et al. (eds.) Geologia do Pré-Devoniano e intrusivas subseqüentes da porção oriental do Estado do Paraná. Boletim Paranaense de Geociências, $\mathrm{n}^{\mathrm{os}} 23$ a 25, p. 237-255

Fúlfaro, V.J.; Saad, A.R.; Santos, M.V. dos; Vianna, R.B. 1982. Compartimentação e evolução tectônica da Bacia do Paraná. Rev. Bras. Geoc., 12 (4): 590-610

Fúlfaro, V.J.; Saad, A.R.; Etchebehere, M.L. de C.; Ciguel, J.H.G.,(in memoriam) 1992. Paleozóico Inferior do Brasil. In: Marco et al. (eds.) Paleozoico Inferior de IberoAmérica. Extremadura, Univ. de Extremadura, 317-330

Gaucher, C. 2000. Sedimentology, palaeontology and stratigraphy of the Arroyo del Soldado Group (Vendian to Cambrian, Uruguay). Beringeria, 24: 1-150

Gaucher, C. \& Sprechmann, P. 1999. Upper Vendian skeletal fauna of the Arroyo del Soldado Group, Uruguay. Beringeria, 23: 55-91

Gaucher, C.; Sprechmann, P.; Schiplov, A. 1996. Upper and Middle Proterozoic fossiliferous sedimentary sequences of the Nico Pérez Terrane of Uruguay: Lithoestratigraphic units, paleontology, depositional environments and correlations. N. Jb. Geol. Paläont. Abh., 199 (3): 339-367

Gaucher, C.; Sprechmann, P.; Montaña, J. 1998. New advances in the geology and paleontology of the Vendian to Cambriam Arroyo del Soldado Group of the Nico Pérez Terrane of Uruguay. N. Jb. Geol. Paläont. Mh. 1998 (2): 106-118

Gaucher, C.; Kawashita, K.; Boggiani, P.C.; Sprechmann, P; Teixeira, W.; Victória, R. 1999. Radiocronologia y quimioestratigrafia del Grupo Arroyo del Soldado (Vendiano Superior-Cambrico Inferior, Uruguay). In: UNIV. DE LA REPÚBLICA, Jornada Académica del Inst. Geol. Paleont., Montevidéo, Resumos, 8-9

Graham, J. 1988. Collection and analysis of field data. In: TUCKER, M. (ed.) Techniques in sedimentology. Blackwell Scientific Publications. p. 5-62

Hachiro, J. \& Santoro, E. 1996. Uma provável bacia terrígeno-carbonática de idade neoproterozóico-eopaleozóica, em Cajamar (SP). An. Acad. Bras. Ci., 68 (4): 601

Hama, M.; Cunha, H.C.S. 1977. Consideração sobre a idade da Formação Pouso Alegre e dos granitos pós-cambrianos na região sul de Minas Gerais e nordeste do Estado de São Paulo. In: SBG, Simp. Reg. Geol., 1, São Paulo, Atas, 48-58

Hama, M.; Algarte, J.P.; Kaefer, L.Q.; Artur, A.C. 1979. Idades Rb/Sr e K/Ar na região sul de

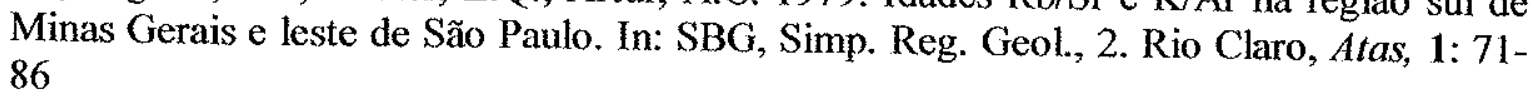

Harnois, L 1988. The CIW Index: A new chemical index of weathering. Sediment. Geol., 55: 319-322

Hartnady, C.J.H.; Joubert, P.; Stowe, C. 1985. Proterozoic crustal evolution of Southwestern Africa. Episodes, 8: 236-244 
Hasui, Y. \& Oliveira, M.A.F. de. 1984. Província Mantiqueira. Setor Central. In: Almeida, F.F.M. de \& Hasui, Y. (eds.) O Pré-Cambriano do Brasil. São Paulo, Edgard Blucher Ltda., 308-344

Hasui, Y.; Almeida, F.F.M. de; Martini, S.L.; Martins, F.A.G. 1982. Modelos metalogenéticos e possibilidades de mineralização no Pré-Cambriano do Estado de São Paulo (Relatório Final). SICCT/PRÓ-MINÉRIO. Relatório IPT nº 17.818, 164p.

Hasui, Y.; Carneiro, C.D.R.; Coimbra, A.M. 1975. The Ribeira folded belt. Rev. Bras. Geoc., 5 (4): $257-266$

Hasui, Y.; Ponçano, W.L.; Bistrichi, C.A.; Stein, D.P.; Galvão, C.A.C.F.; Gimenez Filho, A.; Almeida, M.A. de; Pires Neto, A.G.; Melo, M.S. de; Santos, M. do C.S.R. dos 1978. Geologia da Região Administrativa 3 (Vale do Paraíba) e parte da Região Administrativa 2 (Litoral) do Estado de São Paulo. São Paulo. IPT, Monografias, 1.78 p.

Hasui, Y.; Fonseca, M.J.G.; Ramalho, R. 1984. A parte central da Região de Dobramentos Sudeste e o Maciço Mediano de Guaxupé. In: SCHOBBENHAUS et al. (eds.) Geologia do Brasil. Brasília, MME/DNPM, 307-328

Higgins, M.W. 1971. Cataclastic rocks. USGS Professional Paper 687. 97p.

Hiruma, S. T. 1999. Neotectônica no Planalto de Campos do Jordão, SP. Inst. de Geocências, Universidade de São Paulo, São Paulo, Dissertação de Mestrado, 102 p.

Instituto de Pesquisas tecnológicas do Estado de São Paulo S. A. - IPT 1987. Diagnóstico do abatimento do terreno em Cajamar - SP e definição de modelos e diretrizes para a resolução do problema. São Paulo, IPT. 7 vs. (Relatório 25.053)

Juliani, C.; Beljavskis, P.; Schorscher, H.D. 1986. Petrogênese do vulcanismo e aspectos metalogenéticos associados: Grupo Serra de Itaberaba na região de São Roque-SP. In: CONGR. BRAS. GEOL., 34. Goiânia, 1986. Anais...Goiânia, SBG, v. 2, p. 730-745

Juliani, C.; Riccomini, C.; Barros, E.J. de; Batistucci, L.N. 1990. Proterozoic storm-dominated sedimentation in the Pico de Itapeva Formation (São Paulo State, Brazil). An. Acad. Bras. Ci., 62 (1):105

Keith, M.L. \& Weber, J.N. 1964. Carbon and oxygen isotopic composition of selected limestones and fossils. Geoch. Cosmoch. Acta, 28: 1787-1816.

Leckie, D. A. \& Walker, R. G. 1982. Storm- and tide-dominated shorelines in Cretaceous Moosebar-Lower Gates Interval - outcrop equivalents of deep basin gas trap in Western Canada. The American Association of Petroleum Geologists Bulletin, 66 (2): 138-157.

Le Maitre, R.W.-1989- A Classification of Rocks and Glossary of Terms. London, Blackwell Scientific Publication, 193p.

Leonardos Jr., O.H.; Dunham, A.C.; Pires, F.R.M.; Forman, J.M.A. 1971. Nota sobre a Formação Pouso Alegre. An. Acad. Bras. Ci., 43: 131-143

Loeblich Jr., A.R. \& Tappan, H. 1964. Sarcodina. Chiefly "Thecamoebians" and Foraminiferida. In: Moore, R. C. (ed.) Treatise on invertebrate paleontology; Boulder, Co./Lawrence, Ks., Geol. Soc. Am./Univ. Kansas Press, Part C, Protista 2: C1-C510 
Lowenstam, H.A. \& Weiner, S. 1989. On Biomineralization. New York, Oxford Univ. Press, $324 \mathrm{p}$.

Macedo, M.H.F., Basei, M.A.S.; Bonhomme, M.G.; Kawashita, K. 1984. Dados geocronológicos referentes às rochas metassedimentares do Grupo Itajaí (SC). Rev. Bras. Geoc., 14 (1): $30-34$

Mann, P.; Hempton, M. R.; Bradley, D. C.; Burke, K. 1983. Development of pull-apart basins. The Journ. Geol., 91(5): 529-554

Marini, O.J.; Trein, E.; Fuck, R.A. 1967. O Grupo Açungui no Estado do Paraná. Bol. Paran. Geoc., (23/25): 43-103

McLennan, S.M.; Hemming, S.R.; Taylor, S.R.; Eriksson, K.A. 1995. Early Proterozoic crustal evolution: Geochemical and $\mathrm{Nd}-\mathrm{Pb}$ isotopic evidence from metasedimentary rocks, southwestern North America. Geoch. Cosmochim. Acta, 59 (6): 1153-1177

McPherson, J.G.; Shanmugham, G.; Moiola, R.J. 1987. Fan deltas and braid deltas: varieties of coarse-grained deltas. Geol. Soc. Am. Bull., 99: 331-340

Morais, S. M. 1999. Programa Levantamentos Geológicos Básicos do Brasil: Integração geológica da Folha Guaratinguetá. Escala 1:250.000 SF.23-Y-B. Estados de São Paulo e Minas Gerais. São Paulo, CPRM. 25p.

Moritz Jr., A.R. \& Fiori, A.P. 1987. Análise de seixos deformados da Formação Camarinha. In: SBG, Simp. Sul-Bras. Geol., 3, Curitiba, Anais, 1: 107-121

Muratori, A. 1966 Nota explicativa da Fôlha Geológica de Campo Largo. Univ. Fed. do Paraná, 32p. (Boletim 19)

Muratori, A.; Fuck, R.A.; Bigarella, J.J. 1967. Contribuição ao estudo da Formação Camarinha. In: Bigarella et al. eds. Geologia do Pré-Devoniano e intrusivas subseqüentes da porção oriental do Estado do Paraná. Bol. Par. Geoc., (23-25): 221-235.

Nakazawa, V.A.; Prandini, F.L.; Ávila, I.G.; Ponçano, W.L.; Braga, A.C. de O.; Botura, J.A.; Santoro, E. 1987. Cajamar - Carst e Urbanização: investigação e monitoramento. In: ABGE, Congr. Bras. Geol. Eng., 5, São Paulo, Anais, 2: 443-460

Netto, R.G.; Paim, P.S.G.; Rosa, C.L.M. da. 1992. Informe preliminar sobre a ocorrência de traços fósseis nos sedimentitos das bacias do Camaquã e Santa Bárbara. In: UNISINOS, Workshop sobre as Bacias Molássicas Brasilianas, 1, São Leopoldo, Bol. Esp. Res. Exp., 90m96

Nesbitt, H.W. \& Young, G.M. 1989. Formation and diagenesis of weathering profiles. J. Geol., 97: $129-147$

Nesbitt, H.W. \& Young, G.M. 1982. Early Proterozoic climates and plate motions inferred from major elements chemistry of lutites. Nature, 299: 715-717

Petri, S. \& Suguio, K. 1969. Sobre os metassedimentos do Grupo Açungui no extrêmo sul do Estado de São Paulo. 98 p. (Publicação Especial - Convênio DAEE/USP) 
Pettijohn, F.J.; Potter, P.E.; Siever, R. 1973. Sand and Sandstone. New York, Wiley.

Popp, J.H. 1972. Contribuição à estratigrafia e sedimentologia da Formação Camarinha (PréDevoniano do Estado do Paraná. Bol. Paran. Geociências, 30: 5-71

Ramsay, J.G. 1961. The effects of folding upon the orientation of sedimentation structures. Journal of Geology, 69: 84-100

Riccomini, C. 1989. O Rift Continental do Sudeste do Brasil. Instituto de Geociências, Univ. de São Paulo, São Paulo.Tese de Doutoramento, 256 p.

Riccomini, C. 1993. Origem, evolução e inversão da Bacia do Pico de Itapeva, Neoproterozóicom Cambriano, São Paulo, Brasil. In: DINAMIGE-Fac. Agron., Simp. Intern. del Neoproterozoico-Cambrico de la Cuenca del Plata, 1, La Paloma-Minas, Resumenes Extensos, Tomo I, res. 16

Riccomini, C. \& Coimbra, A.M. 1996. Stratigraphy of the Pico de Itapeva Basin (Neoproterozoic-Cambrian, Southeastern Brazil). An. Acad. Bras. Ciênc., 68 (4): 602

Rodrigues, J.E. 1976. O falhamento transcorrente da Jacutinga. Inst. de Geociências, Universidade de São Paulo, São Paulo. Dissertação de Mestrado, 44p.

Rogers, J.J.W. 1996. A History of Continents in the Past Three Billion Years. J. Geol., 104: 91107

Roser, B.P. \& Korsch, R.J. 1988. Provenance signatures of sandstone-mudstone suites determined using discriminant function analysis of major-element data. Chem. Geol., 67: 119-139

Roser, B.P. \& Korsch, R.J. 1986. Determination of tectonic setting of sandstone-mudstone suites using $\mathrm{SiO}_{2}$ content and $\mathrm{K}_{2} \mathrm{O} / \mathrm{Na}_{2} \mathrm{O}$ ratio. J. Geol., 94: 635-650

Santoro, E. 1998. Evolução geológica do Pré-Cambriano da região de Santo Antonio do Pinhal, SP: importância tectônica das zonas de cisalhamento. Inst. de Geociências, Universidade de São Paulo, São Paulo, Tese de Doutoramento, 153 p.

Santoro, E.; Carneiro, C.D.R.; Oliveira, M.C.B. de; Hachiro, J. 1988. Estrutura geológica da região de Cajamar-Jordanésia, SP. Rev. Bras. Geoc., 18 (3): 353-361

Santoro, E. \& Silva M.E. 1999. Processos deformacionais brasilianos na região de Santo Antonio do Pinhal, SP. An. Acad. Bras. Ciênc., 71 (4): 839-840

Schmitt, R.S; Trouw, R.A.J.; Van Schmus, W.R. 1999. The characterization of a Cambrian $(\sim 520 \mathrm{Ma})$ tectonometamorphic event in the coastal domain of the Ribeira Belt (SE Brazil) - using $\mathrm{U} / \mathrm{Pb}$ in syntectonic veins. In: South American Symposium on Isotope Geology, II, Argentina, Actas, 363-366

Schobbenhaus, C. \& Campos, D. de A. 1984. A evolução da Plataforma Sul-Americana no Brasil e suas principais concentrações minerais. In: Schobbenhaus et al. (eds.) Geologia do Brasil. Brasília, MME/DNPM, 9-53

Soares, P.C. 1976. Projeto Caldas II: Geologia das quadrículas de Santa Rita de Caldas e Ipuína (Relatório Final). Rio Claro, Convênio Depto. Geoc.-FFCL/UNESP - DNPM, 48p. 
Soares, P.C. 1987. Seqüências tecto-sedimentares e tectônica deformadora no centro-oeste do Escudo Paranaense. In: SBG, Simp. Sul-Bras. Geol, 3, Curitiba, Atas, 2: 743-771

Soares, P.C. 1988. Tectônica colisional em torno do Bloco Paraná, Brasil. In: SBG, Congr. Latino-Amer. Geol., 7, Belém, Anais, 1: 63-79

Taylor, S.R. \& McLennan, S.M. 1985. The continental crust: its composition and evolution. Oxford, Blackweel, $312 \mathrm{p}$.

Tchalenko, J. S. \& Ambraseys, N. N. 1970. Structural analysis of the Dasht-e-Bayaz (Iran) earthquake fractures. Geol. Soc. Am. Bull., 81:41-60.

Teixeira, A.L. 1995. Evolução sedimentar e tectônica da Bacia Eleutério. In.: SBG, Simp. Geol. Sud., 5, Águas de São Pedro, Bol. Res., 59

Teixeira, A.L. 1996. Ambientes geradores dos sedimentos da Bacia Eleutério. Inst. de Geociências, Universidade de São Paulo, São Paulo, Dissertação de Mestrado, 132p.

Teixeira, A.L. 1996 Ambientes deposicionais da bacia eopaleozóica de Eleutério (SP-MG). An. Acad. Bras. Ciênc., 68 (4): 601

Teixeira, A.L. \& Petri, S. 1993. Tectônica e sedimentação da Bacia Eleutério (Eopaleozóico?), Sudeste do Brasil. In: DINAMIGE-Fac. Agron., Simp. Intern. del NeoproterozoicoCambrico de la Cuenca del Plata, 1, La Paloma-Minas, Resumenes Extensos, Tomo I, res. 17

Teixeira, A.L. \& Petri, S. 1995. Evolução sedimentar e tectônica da Bacia Eleutério. In: SIMP. GEOL. SUDESTE, 4. Águas de São Pedro, 1995. Bol. Resumos...Águas de São Pedro, SBG/NSP-NRJ/ES. p. 59

Teixeira, A.L.; Cordani, U.G. \& Nutman, A. 1999. Idades U/Pb (SHRIMP) de seixo riolítico em metaconglomerado da Bacia Eleutério, Estado de São Paulo. An Acad. Bras. Ci., 71 (4): $837-838$

Todd, S.P. 1989. Stream-driven, high-density gravelly traction carpets: possible deposits in the Tratberg Conglomerate Formation, SW Ireland and some theoretical considerations of their origin. Sedimentology, 36: 513-530

Toulkeridis, T.; Clauer, N.; Kröner, A.; Reimer, T.; Todt, W. 1999. Characterization, provenance, and tectonic setting of Fig Tree greywackes from the Archaean Barberton Greenstone Belt, South Africa. Sediment. Geol., 124: 113-129

Trein, E. \& Fuck, R.A. 1967. O Grupo Castro. In: Bigarella et al. (eds.) Geologia do préDevoniano e intrusivas subseqüentes da porção oriental do Estado do Paraná. Boletim Paranaense de Geociências, $\mathrm{n}^{\mathrm{s}} 23$ a 25, 257-303

Vasconcellos, A.C.B.C. 1988. O Grupo Andrelândia na região a norte de Ouro Fino, $M G$. Inst. de Geociências, Universidade de São Paulo, São Paulo, Dissertação de Mestrado, 199p.

Vlach, S.R.F. 1993. Geologia e Petrologia dos granitóides de Morungaba, SP. Inst. de Geociências, Universiade de São Paulo, São Paulo. Tese de Doutoramento, 414p. 
Veizer, J. \& Hoefs, J. 1976. The nature of O18/O16 and C13/C12 secular trends in sedimentary carbonate rocks. Geoch. Cosmoch. Acta, 40: 1387-1395

Wernick, E. \& Penalva, F. 1974. Depósitos molassóides da Formação Eleutério, São Paulo, Minas Gerais. In: SBG, Congr. Bras. Geol., 28, Porto Alegre, Res. Comunicações, 723726 (Boletim Especial, 1)

Wernick, E. \& Penalva, F. 1980. Contribuição à geologia do Grupo Pinhal (SP e MG). Rev. Bras. Geoc., 10 (1): 43-62

Wernick, E.; Oliveira, M.A.F. de; Kawashita, K.; Cordani, U.G.; Delhal, J. 1976. Estudo geocronológico pelo método $\mathrm{Rb} / \mathrm{Sr}$ em rochas do Bloco Jundiaí e regiões adjacentes. Rev. Bras. Geoc., 6 (2): 125-135

Zaine, M.F. \& Fairchild, T.R. 1985. Comparision of Aulophycus lucianoi Beurlen \& Sommer from Ladátio (MS) and the genus Cloudina Germs, Ediacaran of Namibia. An. Acad. Bras. Cien., 57: 130

Zaine, M.F. 1991. Análise dos fósseis de parte da Faixa Paraguai (MS, MT) e seu contexto temporal e paleoambiental. Inst. de Geociências, Universidade de São Paulo, São Paulo, Tese de Doutoramento, 218p.

Zanardo, A. 1987. Análise Petrográfica e microestrutural das rochas da Folha de Águas de Lindóia. Inst. de Geociências, Universidade de São Paulo, São Paulo, Dissertação de Mestrado, $270 \mathrm{p}$.

Zanardo, A. \& Oliveira, M.A.F. de 1990. Aspectos microestruturais e texturais dos metassedimentos da Formação Eleutério. Geociências, São Paulo (número especial): $317-330$

Zanardo, A.; Oliveira, M.A.F. de.; Morales, N. 1988. Contribuição ao conhecimento da Formação Eleutério. In: SBG, Congr. Bras. Geol., 35, Belém, Anais, 5: 2308-2317

Zhang, Q. 1988. Early Proterozoic tectonic styles and associated mineral deposits of the north China platform. Precambriam Research, 39: 1-29 
ANEXO 1 
Tabela 1 - Resultados analíticos de elementos maiores das amostras de seixos de riólitos, de metalaminitos com cinzas vulcânicas e de metassiltitos e metarenitos.

\begin{tabular}{|c|c|c|c|c|c|c|c|c|}
\hline AMOSTRA & $\mathrm{SiO} 2$ & Al203 & $\mathrm{Fe} 2 \mathrm{O3}$ & Mno & MgO & $\mathrm{CaO}$ & $\mathrm{Na2O}$ & $\mathrm{K} 2 \mathrm{O}$ \\
\hline & $\%$ wt & $\% w t$ & $\% w t$ & $\% w t$ & $\% w t$ & $\% w t$ & $\% w t$ & $\% w t$ \\
\hline CA-01 & 77.78 & 10.27 & 2.33 & 0.05 & 0.56 & 0.53 & 2.42 & 2.67 \\
\hline$C A-11$ & 63.12 & 15.12 & 6.29 & 0.14 & 2.74 & 2.11 & 1.55 & 3.24 \\
\hline CA-18 & 74.10 & 12.52 & 1.71 & 0.02 & 0.58 & 1.22 & 2.85 & 3.62 \\
\hline CJ -01 & 2.27 & 0.16 & 0.18 & 0.06 & 4.62 & 50.13 & 0.02 & 0.04 \\
\hline CJ-02 & 6.15 & 0.42 & 0.38 & 0.04 & 11.70 & 38.27 & 0.02 & 0.13 \\
\hline CJ -03 & 51.69 & 0.86 & 2.18 & 0.06 & 6.04 & 17.66 & 0.03 & 0.35 \\
\hline $\mathrm{CJ}^{-04}$ & 5.51 & 0.84 & 7.51 & 0.18 & 14.56 & 28.94 & 0.04 & 0.29 \\
\hline CJ-06 & 64.35 & 16.04 & 5.56 & 0.01 & 1.91 & 1.54 & 0.05 & 6.06 \\
\hline C.J-07 & 9.22 & 1.91 & 1.07 & 0.04 & 2.17 & 46.74 & 0.03 & 0.65 \\
\hline ET-54-2 & 75.44 & 11.21 & 1.71 & 0.02 & 0.19 & 0.06 & 0.28 & 9.18 \\
\hline ET-54-3 & 72.32 & 11.15 & 2.15 & 0.02 & 0.16 & 0.17 & 0.28 & 9.26 \\
\hline ET-54-3 & 71.16 & 10.93 & 2.16 & 0.02 & 0.14 & 0.16 & 0.28 & 9.37 \\
\hline ET-54-4 & 69.61 & 10.76 & 1.67 & 0.03 & 0.26 & 0.38 & 0.40 & 8.89 \\
\hline ET-54-4 & 68.48 & 10.69 & 1.67 & 0.03 & 0.24 & 0.36 & 0.40 & 8.75 \\
\hline ET-54-6 & 73.66 & 12.06 & 2.10 & 0.03 & 0.18 & 0.11 & 0.50 & 9.59 \\
\hline ET-54-7 & 74.95 & 11.47 & 1.68 & 0.02 & 0.06 & 0.08 & 0.29 & 9.78 \\
\hline ET-54-8 & 73.67 & 12.15 & 1.75 & 0.02 & 0.12 & 0.17 & 0.41 & 9.68 \\
\hline ET-54-10 & 68.59 & 11.51 & 1.71 & 0.02 & 0.17 & 0.05 & 0.19 & 9.75 \\
\hline ET-54-10 & 68.40 & 11.19 & 1.71 & 0.02 & 0.15 & 0.04 & 0.19 & 9.53 \\
\hline ET-54-11 & 73.92 & 11.50 & 2.10 & 0.03 & 0.29 & 0.04 & 0.25 & 9.47 \\
\hline$E T-64 B$ & 64.63 & 14.39 & 6.73 & 0.08 & 2,11 & 1.54 & 1.74 & 3.83 \\
\hline NC-088 & 27.15 & 3.05 & 1.94 & 0.07 & 14.14 & 20.26 & 0.03 & 0.93 \\
\hline $\mathrm{NC}-23$ & 3.66 & 0.75 & 0.35 & -0.01 & 3.90 & 49.94 & 0.04 & 0.13 \\
\hline PA-15 & 67.18 & 13.15 & 5.15 & 0.09 & 2.12 & 3.36 & 2.18 & 2.52 \\
\hline VS.01 & 64,98 & 18.76 & 1.89 & -0.01 & 0.99 & 0.02 & 0.06 & 4.01 \\
\hline VS-02 & 66.86 & 18.26 & 2.68 & 0.02 & 0.96 & 0.02 & 0.08 & 4.15 \\
\hline VS-03 & 63.38 & 19.78 & 3.64 & 0.01 & 1.00 & -0.01 & 0.06 & 4.00 \\
\hline VS-04 & 65.10 & 18.77 & 4.28 & -0.01 & 0.93 & -0.01 & 0.06 & 3.65 \\
\hline VS-06 & 64.50 & 21.69 & 1.49 & -0.01 & 0.97 & 0.02 & 0.06 & 3.76 \\
\hline VS-09 & 60.96 & 19.48 & 7.07 & 0.01 & 0.98 & -0.01 & 0.06 & 3.77 \\
\hline VS-11 & 66.98 & 16.80 & 6.09 & -0.01 & 1.15 & 0.01 & 0.06 & 4.94 \\
\hline VS-12 & 59.87 & 18.73 & 7.82 & 0.02 & 1.08 & -0.01 & 0.07 & 3.68 \\
\hline VS-13 & 62.84 & 18.40 & 6.73 & -0.01 & 0.85 & -0.01 & 0.07 & 3.87 \\
\hline
\end{tabular}


Continuação Tabela 1

\begin{tabular}{|c|c|c|c|c|c|c|c|c|}
\hline AMOSTRA & TiO2 & P205 & $\mathrm{LOI}$ & TOTAL & $\mathrm{Ba}$ & $\mathrm{Sr}$ & $\bar{Y}$ & Sc \\
\hline & $\% w t$ & $\%$ wt & $\%$ wt & $\% \mathrm{wt}$ & $\mathrm{ppm}$ & $\mathrm{ppm}$ & $\mathrm{ppm}$ & $\mathrm{ppm}$ \\
\hline CA-01 & 0.376 & 0.11 & 1.48 & 98.57 & 665 & 144 & 17 & 5 \\
\hline $\mathrm{CA}-11$ & 0.731 & 0.17 & 4.57 & 99.77 & 678 & 106 & 84 & 15 \\
\hline CA-18 & 0.357 & 0.12 & 2.16 & 99.26 & 1033 & 297 & 23 & 3 \\
\hline CJ-01 & -0.001 & -0.01 & 42.81 & 100.30 & 28 & 121 & 2 & -1 \\
\hline $\mathrm{CJ}-02$ & 0.013 & 0.02 & 42.05 & 99.18 & 38 & 137 & 3 & -1 \\
\hline $\mathrm{CJ}-03$ & 0.027 & 0.10 & 20.75 & 99.74 & 322 & 91 & 7 & 1 \\
\hline CJ-04 & 0.024 & 2.45 & 38.14 & 98.50 & 86 & 228 & 56 & 4 \\
\hline $\mathrm{CJ}-06$ & 0.560 & 0.14 & 4.76 & 100.98 & 660 & 26 & 20 & 13 \\
\hline C.J.07 & 0.080 & 0.12 & 38.29 & 100.32 & 70 & 251 & 10 & 2 \\
\hline ET-54-2 & 0.102 & 0.02 & 0.51 & 98.73 & 2134 & 86 & 8 & 2 \\
\hline ET-54-3 & 0.090 & 0.02 & 0.58 & 96.20 & 2848 & 82 & 17 & -1 \\
\hline ET-54-3 & 0.091 & 0.02 & 0.58 & 94.92 & 2845 & 83 & 18 & -1 \\
\hline ET-54-4 & 0.064 & 0.01 & 0.69 & 92.76 & 2578 & 130 & 14 & -1 \\
\hline ET-54-4 & 0.065 & 0.02 & 0.69 & 91.38 & 2585 & 130 & 16 & 1 \\
\hline ET-54-6 & 0.106 & 0.03 & 0.63 & 98.98 & 3001 & 123 & 44 & 2 \\
\hline ET-54-7 & 0.065 & 0.03 & 0.32 & 98.75 & 2002 & 110 & 10 & 1 \\
\hline ET-54-8 & 0.092 & 0.02 & 0.47 & 98.54 & 3275 & 134 & 28 & 1 \\
\hline ET-54-10 & 0.062 & 0.01 & 0.58 & 92.64 & 2490 & 89 & 8 & -1 \\
\hline ET-54-10 & 0.065 & 0.01 & 0.58 & 91.89 & 2429 & 87 & 8 & -1 \\
\hline ET-54-11 & 0.101 & 0.30 & 0.67 & 98.67 & 2192 & 89 & 10 & -1 \\
\hline$E T-64 B$ & 1.010 & 0.33 & 2.71 & 99.08 & 887 & 125 & 46 & 14 \\
\hline NC-088 & 0.129 & 0.03 & 31.79 & 99.53 & 153 & 842 & 13 & 4 \\
\hline NC-23 & 0.028 & 0.02 & 42.10 & 100.91 & 82 & 983 & 4 & 1 \\
\hline PA-15 & 0.950 & 0.33 & 3.81 & 100.84 & 587 & 218 & 116 & 13 \\
\hline$V S-01$ & 0.947 & 0.12 & 7.05 & 98.83 & 1237 & 82 & 52 & 19 \\
\hline VS-02 & 0.869 & 0.06 & 4.88 & 98.81 & 957 & 24 & 49 & 16 \\
\hline VS-03 & 0.966 & 0.10 & 5.96 & 98.90 & 944 & 24 & 48 & 18 \\
\hline VS-04 & 0.933 & 0.11 & 5.90 & 99.74 & 869 & 19 & 44 & 18 \\
\hline VS-06 & 0.914 & 0.19 & 7.10 & 100.70 & 2114 & 116 & 45 & 19 \\
\hline$\overline{V S}-09$ & 0.898 & 0.15 & 6.59 & 99.95 & 1054 & 35 & 43 & 19 \\
\hline$V S-11$ & 0.865 & 0.05 & 3.94 & 100.90 & 957 & 19 & 49 & 17 \\
\hline VS-12 & 0.916 & 0.09 & 6.64 & 98.92 & 743 & 11 & 83 & 20 \\
\hline VS-13 & 0.906 & 0.10 & 5.83 & 99.60 & 813 & 20 & 43 & 19 \\
\hline
\end{tabular}


Continuação Tabela 1

\begin{tabular}{|l|c|c|c|}
\hline AMOSTRA & Zr & Be & $V$ \\
\hline & $p p m$ & $p p m$ & $p p m$ \\
\hline CA-01 & 241 & 3 & 35 \\
\hline CA-11 & 219 & 6 & 93 \\
\hline CA-18 & 210 & 2 & 29 \\
\hline CJ-01 & 6 & -1 & -5 \\
\hline CJ-02 & 14 & -1 & 6 \\
\hline CJ-03 & 12 & -1 & 6 \\
\hline CJ-04 & 41 & -1 & 19 \\
\hline CJ-06 & 155 & 2 & 68 \\
\hline CJ-07 & 22 & -1 & 10 \\
\hline ET-54-2 & 345 & 2 & 10 \\
\hline ET-54-3 & 421 & 3 & 10 \\
\hline ET-54-3 & 427 & 3 & 9 \\
\hline ET-54-4 & 363 & 2 & 13 \\
\hline ET-54-4 & 352 & 2 & 12 \\
\hline ET-54-6 & 430 & 7 & 11 \\
\hline ET-54-7 & 413 & 2 & 8 \\
\hline ET-54-8 & 299 & 3 & 9 \\
\hline ET-54-10 & 389 & 1 & 11 \\
\hline ET-54-10 & 388 & 1 & 9 \\
\hline ET-54-11 & 440 & 2 & 13 \\
\hline ET-64B & 672 & 2 & 96 \\
\hline NC-088 & 39 & -1 & 24 \\
\hline NC-23 & 12 & -1 & 10 \\
\hline PA-15 & 483 & 2 & 81 \\
\hline VS-01 & 202 & 3 & 132 \\
\hline VS-02 & 181 & 3 & 120 \\
\hline VS-03 & 196 & 4 & 136 \\
\hline VS-04 & 196 & 4 & 127 \\
\hline VS-06 & 195 & 7 & 127 \\
\hline VS-09 & 187 & 5 & 134 \\
\hline VS-11 & 236 & 3 & 111 \\
\hline VS-12 & 193 & 3 & 135 \\
\hline VS-13 & 193 & 3 & 124 \\
\hline & & & \\
\hline
\end{tabular}


Tabela 2 - Resultados analíticos para elementos traços, de amostras de seixos de riólitos, de metalaminitos com cinzas vulcânicas e de metassiltitos e metarenitos.

\begin{tabular}{|c|c|c|c|c|c|c|c|c|}
\hline AMOSTRA & v & $\mathrm{Cr}$ & $\mathrm{Co}$ & $\mathrm{Ni}$ & $\mathrm{Cu}$ & $\mathrm{Zn}$ & $\mathrm{Ga}$ & $\mathrm{Ge}$ \\
\hline & $\mathrm{ppm}$ & $\mathrm{ppm}$ & $\mathrm{ppm}$ & ppm & $\mathrm{ppm}$ & $\mathrm{ppm}$ & $\mathrm{ppm}$ & $\mathrm{ppm}$ \\
\hline CA-01 & 32 & -20 & 4 & -15 & -10 & 40 & 11 & 1 \\
\hline CA-11 & 91 & 67 & 16 & 84 & 40 & 378 & 21 & 2 \\
\hline$C A-18$ & 28 & -20 & 2 & -15 & -10 & -30 & 14 & 1 \\
\hline $\mathrm{CJ}-01$ & -5 & -20 & -1 & 18 & 21 & -30 & -1 & -1 \\
\hline $\mathrm{CJ}=02$ & -5 & -20 & -1 & 15 & 16 & -30 & -1 & -1 \\
\hline $\mathrm{CJ}-03$ & 5 & -20 & -1 & -15 & .10 & -30 & 2 & -1 \\
\hline CJ-04 & 16 & 29 & 21 & 38 & 22 & -30 & 2 & -1 \\
\hline $\mathrm{CJ}-06$ & 62 & 55 & 14 & 25 & 14 & 46 & 20 & 2 \\
\hline CJ -07 & 8 & -20 & -1 & 19 & 17 & .30 & 2 & -1 \\
\hline ET-54-2 & 6 & -20 & -1 & -15 & 11 & 58 & 11 & -1 \\
\hline ET-54-2 REP & 6 & -20 & -1 & -15 & -10 & 51 & 12 & -1 \\
\hline ET-54-3 & 8 & -20 & 1 & -15 & -10 & -30 & 10 & -1 \\
\hline ET-54-4 & 10 & -20 & -1 & -15 & -10 & 50 & 10 & -1 \\
\hline ET-54-6 & 8 & -20 & 1 & -15 & 21 & 41 & 12 & -1 \\
\hline ET-54-7 & 5 & -20 & -1 & -15 & 21 & 44 & 13 & -1 \\
\hline ET-54.8 & 7 & -20 & -1 & -15 & -10 & -30 & 10 & -1 \\
\hline ET-54-10 & 7 & -20 & -1 & -15 & -10 & 60 & 10 & -1 \\
\hline ET-54-11 & 13 & -20 & -1 & -15 & -10 & 65 & 12 & -1 \\
\hline ET-64B & 86 & 67 & 17 & 34 & 11 & 63 & 21 & 1 \\
\hline NC-088 & 21 & -20 & -1 & -15 & -10 & -30 & 4 & -1 \\
\hline $\mathrm{NC}-23$ & 7 & -20 & -1 & -15 & 16 & -30 & -1 & -1 \\
\hline PA-15 & 77 & 73 & 12 & 26 & -10 & 63 & 17 & 1 \\
\hline VS-01 & 122 & 79 & 1 & -15 & -10 & -30 & 25 & 2 \\
\hline VS-02. & 121 & 82 & 3 & -15 & 12 & -30 & 24 & 2 \\
\hline VS-03 & 128 & 79 & 4 & -15 & 12 & -30 & 26 & 2 \\
\hline VS-04 & 123 & 82 & 2 & 17 & 17 & -30 & 25 & 1 \\
\hline VS-06 & 115 & 83 & 2 & -15 & -10 & -30 & 24 & 1 \\
\hline VS-09 & 126 & 94 & 3 & 35 & 34 & 56 & 25 & 2 \\
\hline VS-09REP & 123 & 92 & 3 & 33 & 33 & 66 & 24 & 2 \\
\hline VS-11 & 108 & 82 & 9 & 21 & 17 & 65 & 23 & 2 \\
\hline VS-12 & 130 & 131 & 3 & 15 & 23 & 34 & 26 & 2 \\
\hline VS-13 & 117 & 81 & 5 & 29 & 50 & 63 & 24 & 1 \\
\hline
\end{tabular}


Continuação Tabela 2

\begin{tabular}{|c|c|c|c|c|c|c|c|c|}
\hline AMOSTRA & As & $\mathbf{R b}$ & $\mathrm{Sr}$ & $\mathrm{Y}$ & $\mathrm{zr}$ & $\mathrm{Nb}$ & Mo & $\mathrm{Ag}$ \\
\hline & $\mathrm{ppm}$ & $\mathrm{ppm}$ & $\mathrm{ppm}$ & $\mathrm{ppm}$ & $\mathrm{ppm}$ & ppm & ppm & $\mathrm{ppm}$ \\
\hline CA-01 & 7 & 114 & 135 & 16 & 243 & 9 & -2 & 0.6 \\
\hline$C A-11$ & 12 & 156 & 106 & 85 & 235 & 16 & -2 & -0.5 \\
\hline CA-18 & -5 & 107 & 268 & 21 & 212 & 11 & -2 & -0.5 \\
\hline C. -01 & -5 & -2 & 118 & 2 & -5 & -1 & -2 & -0.5 \\
\hline Cu-02 & -5 & 3 & 131 & 2 & 12 & -1 & -2 & -0.5 \\
\hline $\mathrm{CJ}-03$ & -5 & 8 & 88 & 6 & 17 & -1 & -2 & -0.5 \\
\hline CJ-04 & -5 & 7 & 224 & 55 & 62 & 1 & -2 & -0.5 \\
\hline CJJ-06 & -5 & 151 & 25 & 19 & 161 & 9 & -2 & -0.5 \\
\hline CJ-07 & -5 & 16 & 239 & 9 & 16 & 2 & -2 & -0.5 \\
\hline ET-54-2 & .5 & 375 & 80 & 7 & 337 & 49 & -2 & -0.5 \\
\hline ET-54-2 REP & .5 & 368 & 78 & 7 & 339 & 51 & -2 & -0.5 \\
\hline ET $-54-3$ & -5 & 342 & 76 & 17 & 427 & 66 & 2 & -0.5 \\
\hline ET-54 & -5 & 320 & 120 & 14 & 352 & 64 & -2 & -0.5 \\
\hline ET-54-6 & -5 & 330 & 111 & 41 & 420 & 64 & -2 & -0.5 \\
\hline ET-54-7 & -5 & 404 & 100 & 9 & 408 & 83 & -2 & -0.5 \\
\hline ET-54n8 & .5 & 316 & 119 & 25 & 290 & 53 & -2 & -0.5 \\
\hline ET-54-10 & -5 & 366 & 79 & 7 & 386 & 72 & -2 & -0.5 \\
\hline ET-54-11 & -5 & 368 & 84 & 9 & 451 & 64 & -2 & -0.5 \\
\hline ET-64B & .5 & 145 & 123 & 46 & 663 & 22 & -2 & -0.5 \\
\hline NC-088 & -5 & 35 & 791 & 13 & 35 & 3 & -2 & -0.5 \\
\hline $\mathrm{NC}-23$ & -5 & 5 & 923 & 3 & 8 & -1 & -2 & 0.6 \\
\hline PA-15 & -5 & 113 & 209 & 114 & 499 & 19 & -2 & -0.5 \\
\hline VS-01 & -5 & 165 & 77 & 50 & 203 & 19 & -2 & -0.5 \\
\hline VS-02 & 13 & 168 & 22 & 50 & 194 & 19 & -2 & -0.5 \\
\hline VS-03 & 8 & 171 & 22 & 47 & 197 & 20 & -2 & -0.5 \\
\hline VS-04 & -5 & 157 & 19 & 43 & 204 & 20 & -2 & -0.5 \\
\hline VS-06 & 6 & 152 & 108 & 42 & 191 & 19 & -2 & -0.5 \\
\hline VS-09 & 6 & 167 & 33 & 42 & 187 & 20 & -2 & -0.5 \\
\hline VSm09 REP & 9 & 167 & 33 & 41 & 184 & 19 & -2 & -0.5 \\
\hline VS-11 & -5 & 210 & 17 & 47 & 244 & 18 & -2 & -0.5 \\
\hline VS-12 & 6 & 162 & 10 & 78 & 198 & 19 & -2 & -0.5 \\
\hline VS-13 & 16 & 148 & 18 & 39 & 196 & 19 & -2 & -0.5 \\
\hline
\end{tabular}


Continuação Tabela 2

\begin{tabular}{|c|c|c|c|c|c|c|c|c|}
\hline AMOSTRA & In & Sn & $\mathrm{sb}$ & Cs & $\mathrm{Ba}$ & La & $\mathrm{Ce}$ & $\mathrm{Pr}$ \\
\hline & $\mathrm{ppm}$ & $\mathrm{ppm}$ & $\mathrm{ppm}$ & $\mathrm{ppm}$ & $\mathrm{ppm}$ & $\mathrm{ppm}$ & ppm & $\mathrm{ppm}$ \\
\hline $\mathrm{CA}-01$ & -0.2 & 2 & 1.6 & 4.3 & 592 & 17.9 & 39.1 & 4.18 \\
\hline $\mathrm{CA}-11$ & -0.2 & 3 & 1.3 & 8.2 & 650 & 80.1 & 112 & 17.9 \\
\hline CA-18 & -0.2 & 1 & 0.6 & 2.4 & 1,010 & 54.9 & 82.1 & 11.0 \\
\hline CJ.01 & -0.2 & -1 & -0.5 & -0.5 & 25 & 1.6 & 2.8 & 0.32 \\
\hline CJ -02 & -0.2 & -1 & 0.8 & -0.5 & 34 & 2.3 & 4.8 & 0.52 \\
\hline $\mathrm{CJ}-03$ & -0.2 & -1 & -0.5 & -0.5 & 299 & 5.9 & 8.9 & 1.18 \\
\hline CJ 04 & -0.2 & -1 & 1.1 & 0.5 & 79 & 31.5 & 67.4 & 6.29 \\
\hline CJ-06 & -0.2 & 2 & 1.0 & 7.3 & 597 & 41.7 & 79.6 & 9.65 \\
\hline $\mathrm{CJ}-07$ & -0.2 & -1 & 0.6 & 1.0 & 65 & 7.9 & 12.5 & 1.77 \\
\hline$E T-54-2$ & -0.2 & 6 & -0.5 & 2.8 & 2,070 & 17.9 & 19.5 & 4.73 \\
\hline ET-54-2 REP & -0.2 & 6 & -0.5 & 2.8 & 2,030 & 17.9 & 19.5 & 4.76 \\
\hline ET-54-3 & -0.2 & 10 & -0.5 & 3.3 & 2,770 & 21.3 & 50.0 & 5.00 \\
\hline ET-54-4 & -0.2 & 8 & -0.5 & 2.1 & 2,480 & 16.0 & 34.9 & 3.73 \\
\hline ET-54-6 & -0.2 & 7 & 1.8 & 2.2 & 2,840 & 32.8 & 93.2 & 8.82 \\
\hline ET-54-7 & -0.2 & 53 & -0.5 & 3.0 & 1,930 & 14.6 & 26.4 & 3.37 \\
\hline ET-54-8 & -0.2 & 4 & -0.5 & 1.8 & 3,080 & 25.4 & 85.9 & 6.18 \\
\hline ET.54-10 & -0.2 & 8 & -0.5 & 2.4 & 2,330 & 8.1 & 17.7 & 2.06 \\
\hline ET-54-11 & -0.2 & 7 & -0.5 & 2.3 & 2,170 & 6.8 & 12.2 & 2.25 \\
\hline ET-64B & -0.2 & 4 & 0.8 & 8.9 & 928 & 61.8 & 121 & 14.2 \\
\hline NC-088 & -0.2 & -1 & -0.5 & 0.6 & 140 & 9.6 & 18.6 & 2.37 \\
\hline $\mathrm{NC}-23$ & -0.2 & -1 & -0.5 & -0.5 & 73 & 3.2 & 5.9 & 0.72 \\
\hline$P A-15$ & -0.2 & 3 & 0.8 & 5.7 & 535 & 74.8 & 112 & 16.8 \\
\hline VS-01 & -0.2 & 4 & 1.8 & 6.6 & 1,230 & 125 & 132 & 26.2 \\
\hline VS-02 & -0.2 & 4 & 1.1 & 6.6 & 878 & 86.3 & 92.7 & 18.8 \\
\hline VS-03 & -0.2 & 4 & 1.5 & 7.2 & 851 & 96.0 & 90.1 & 20.0 \\
\hline VS-04 & -0.2 & 4 & 0.6 & 6.2 & 805 & 79.5 & 81.4 & 16.2 \\
\hline VS.06 & -0.2 & 4 & 1.0 & 5.3 & 2,050 & 85.7 & 107 & 14.6 \\
\hline VS.09 & -0.2 & 4 & 0.9 & 7.5 & 1,060 & 96.3 & 93.8 & 18.8 \\
\hline VSU09 REP & -0.2 & 4 & 1.4 & 7.9 & 1,030 & 93.6 & 90.7 & 18.4 \\
\hline VS-11 & -0.2 & 3 & 1.5 & 9.1 & 962 & 77.3 & 104 & 17.2 \\
\hline VS-12 & -0.2 & 4 & 0.8 & 8.2 & 668 & 95.5 & 35.8 & 20.9 \\
\hline VS-13 & -0.2 & 3 & 1.1 & 6.0 & 733 & 76.9 & 89.9 & 17.5 \\
\hline
\end{tabular}


Continuação Tabela 2

\begin{tabular}{|l|c|c|c|c|c|c|c|c|}
\hline AMOSTRA & Nd & Sm & Eu & Gd & Tb & Dy & Ho & Er \\
\hline & ppm & ppm & ppm & ppm & ppm & ppm & ppm & ppm \\
\hline CA-01 & 15.2 & 3.0 & 0.65 & 2.6 & 0.5 & 2.8 & 0.6 & 1.8 \\
\hline CA-11 & 71.1 & 14.5 & 3.11 & 14.3 & 2.6 & 15.3 & 3.0 & 9.4 \\
\hline CA-18 & 39.3 & 6.2 & 1.42 & 4.8 & 0.7 & 3.7 & 0.7 & 2.2 \\
\hline CJ-01 & 1.2 & 0.3 & 0.06 & 0.2 & -0.1 & 0.3 & -0.1 & 0.1 \\
\hline CJ-02 & 2.0 & 0.4 & 0.11 & 0.4 & -0.1 & 0.4 & -0.1 & 0.2 \\
\hline CJ-03 & 4.6 & 0.9 & 0.20 & 0.9 & 0.1 & 0.9 & 0.2 & 0.6 \\
\hline CJ-04 & 25.1 & 4.2 & 1.76 & 5.8 & 1.0 & 5.8 & 1.2 & 3.3 \\
\hline CJ-06 & 35.7 & 6.6 & 1.28 & 5.1 & 0.7 & 3.7 & 0.7 & 2.0 \\
\hline CJ-07 & 7.0 & 1.3 & 0.32 & 1.3 & 0.2 & 1.4 & 0.3 & 0.8 \\
\hline ET-54-2 & 16.5 & 3.5 & 0.11 & 2.3 & 0.4 & 2.0 & 0.4 & 1.4 \\
\hline ET-54-2REP & 16.3 & 3.5 & 0.12 & 2.4 & 0.4 & 2.0 & 0.4 & 1.3 \\
\hline ET-54-3 & 17.8 & 3.9 & 0.31 & 2.9 & 0.6 & 4.1 & 0.9 & 3.2 \\
\hline ET-54-4 & 13.3 & 3.1 & 0.13 & 2.2 & 0.5 & 3.1 & 0.6 & 2.3 \\
\hline ET-54-6 & 31.1 & 7.4 & 0.29 & 5.9 & 1.4 & 8.4 & 1.7 & 5.9 \\
\hline ET-54-7 & 11.7 & 2.3 & 0.07 & 1.7 & 0.4 & 2.0 & 0.4 & 1.5 \\
\hline ET-54-8 & 22.3 & 4.9 & 0.25 & 3.5 & 0.9 & 5.7 & 1.2 & 4.2 \\
\hline ET-54-10 & 9.1 & 1.9 & 0.18 & 1.2 & 0.2 & 1.3 & 0.3 & 1.1 \\
\hline ET-54-11 & 10.6 & 2.3 & 0.22 & 1.7 & 0.3 & 1.6 & 0.3 & 1.2 \\
\hline ET-64B & 52.6 & 9.6 & 1.68 & 8.4 & 1.4 & 8.0 & 1.6 & 5.0 \\
\hline NC-088 & 9.6 & 2.1 & 0.55 & 2.0 & 0.4 & 2.0 & 0.4 & 1.2 \\
\hline NC-23 & 2.7 & 0.5 & 0.13 & 0.5 & -0.1 & 0.4 & -0.1 & 0.3 \\
\hline PA-15 & 67.4 & 14.7 & 3.51 & 17.3 & 3.2 & 18.8 & 3.9 & 11.9 \\
\hline VS-01 & 93.6 & 16.6 & 3.44 & 13.3 & 1.8 & 9.2 & 1.6 & 4.7 \\
\hline VS-02 & 68.1 & 11.3 & 2.55 & 9.8 & 1.4 & 7.7 & 1.5 & 4.7 \\
\hline VS-03 & 71.9 & 11.7 & 2.59 & 10.3 & 1.4 & 7.4 & 1.4 & 4.4 \\
\hline VS-04 & 57.9 & 9.2 & 2.02 & 8.2 & 1.2 & 6.6 & 1.3 & 4.0 \\
\hline VS-06 & 51.9 & 10.9 & 2.61 & 11.4 & 2.0 & 10.2 & 1.7 & 4.4 \\
\hline VS-09 & 66.6 & 12.1 & 2.79 & 11.0 & 1.7 & 8.6 & 1.5 & 4.2 \\
\hline VS-09 REP & 64.2 & 11.9 & 2.73 & 11.0 & 1.7 & 8.5 & 1.4 & 4.2 \\
\hline VS-11 & 63.3 & 11.3 & 2.28 & 9.6 & 1.4 & 7.6 & 1.5 & 4.6 \\
\hline VS-12 & 76.4 & 14.6 & 3.31 & 15.0 & 2.4 & 13.1 & 2.5 & 7.5 \\
\hline VS-13 & 64.1 & 11.2 & 2.29 & 9.0 & 1.3 & 7.1 & 1.4 & 4.2 \\
\hline
\end{tabular}


Continuação Tabela 2

\begin{tabular}{|c|c|c|c|c|c|c|c|c|}
\hline AMOSTRA & $\mathrm{Tm}$ & $\overline{Y b}$ & Lu & $\mathrm{Hf}$ & Ta & $\mathbf{w}$ & $\mathrm{TI}$ & $\mathbf{P b}$ \\
\hline & $\mathrm{ppm}$ & $\mathrm{ppm}$ & ppm & $\mathrm{ppm}$ & $\mathrm{ppm}$ & $\mathrm{ppm}$ & $\mathrm{ppm}$ & $\mathrm{ppm}$ \\
\hline $\mathrm{CA}-01$ & 0.27 & 1.8 & 0.28 & 6.3 & 0.8 & 0.9 & 0.7 & 23 \\
\hline CA-11 & 1.40 & 9.1 & 1.24 & 6.4 & 1.2 & 2.1 & 0.8 & 17 \\
\hline$\overline{C A-18}$ & 0.33 & 2.2 & 0.33 & 5.4 & 0.9 & 0.7 & 0.5 & 15 \\
\hline CJ -01 & -0.05 & 0.1 & -0.04 & -0.2 & -0.1 & -0.5 & -0.1 & -5 \\
\hline$\overline{C J}-02$ & -0.05 & 0.2 & -0.04 & 0.2 & -0.1 & -0.5 & -0.1 & -5 \\
\hline CJ-03 & 0.07 & 0.5 & 0.07 & 0.4 & -0.1 & -0.5 & -0.1 & -5 \\
\hline CJ-04 & 0.40 & 2.3 & 0.33 & 1.0 & -0.1 & -0.5 & -0.1 & 5 \\
\hline CJ-06 & 0.27 & 1.8 & 0.27 & 4.1 & 0.8 & -0.5 & 0.4 & -5 \\
\hline CJ-07 & 0.12 & 0.8 & 0.12 & 0.4 & 0.1 & -0.5 & -0.1 & -5 \\
\hline ET-54\%2 & 0.22 & 1.7 & 0.28 & 11.8 & 3.5 & -0.5 & 2.0 & 10 \\
\hline ET-54-2REP & 0.23 & 1.7 & 0.28 & 12.0 & 3.6 & -0.5 & 1.7 & 7 \\
\hline ET-54-3 & 0.54 & 3.9 & 0.54 & 17.2 & 5.1 & 0.7 & 1.7 & 8 \\
\hline ET $-54-4$ & 0.39 & 2.8 & 0.40 & 14.5 & 4.7 & 1.1 & 1.9 & 11 \\
\hline ET-54-6 & 0.95 & 6.6 & 0.95 & 14.8 & 4.3 & -0.5 & 1.8 & 7 \\
\hline ET-54-7 & 0.27 & 2.0 & 0.30 & 17.2 & 5.8 & 1.1 & 1.7 & 7 \\
\hline ET-54-8 & 0.67 & 4.7 & 0.66 & 11.0 & 3.8 & -0.5 & 1.8 & 7 \\
\hline ET-54-10 & 0.21 & 1.6 & 0.26 & 16.3 & 5.1 & -0.5 & 2.2 & 12 \\
\hline ET-54-11 & 0.21 & 1.6 & 0.25 & 15.8 & 4.2 & -0.5 & 2.0 & 7 \\
\hline ET-64B & 0.75 & 4.9 & 0.74 & 17.5 & 1.8 & 2.0 & 0.8 & 16 \\
\hline NC-088 & 0.17 & 1.1 & 0.15 & 1.0 & 0.2 & 0.8 & 0.2 & -5 \\
\hline NC-23 & -0.05 & 0.2 & -0.04 & -0.2 & -0.1 & -0.5 & -0.1 & -5 \\
\hline PA-15 & 1.58 & 10.0 & 1.39 & 12.9 & 1.4 & 1.9 & 0.5 & 12 \\
\hline VS-01 & 0.64 & 4.0 & 0.58 & 5.4 & 1.4 & 2.4 & 0.8 & 46 \\
\hline VS-02 & 0.66 & 4.4 & 0.64 & 5.0 & 1.4 & 2.5 & 0.7 & 5 \\
\hline VS-03 & 0.62 & 4.0 & 0.60 & 5.4 & 1.5 & 2.5 & 0.8 & 9 \\
\hline VS-04 & 0.56 & 3.5 & 0.53 & 5.3 & 1.5 & 2.3 & 0.6 & 7 \\
\hline VS-06 & 0.55 & 3.3 & 0.44 & 5.3 & 1.4 & 2.1 & 0.6 & 22 \\
\hline VS-09 & 0.57 & 3.5 & 0.51 & 5.2 & 1.5 & 2.1 & 0.7 & $\overline{13}$ \\
\hline VS-09 REP & 0.56 & 3.5 & 0.51 & 5.0 & 1.5 & 2.1 & 0.9 & 19 \\
\hline VS-11 & 0.66 & 4.2 & 0.62 & 6.5 & 1.4 & 2.0 & 1.1 & 13 \\
\hline VS-12 & 1.00 & 6.0 & 0.83 & 5.5 & 1.4 & 2.2 & 0.9 & 5 \\
\hline VS-13 & 0.61 & 4.0 & 0.57 & 5.3 & 1.4 & 2.4 & 0.8 & 20 \\
\hline
\end{tabular}


Continuação Tabela 2

\begin{tabular}{|l|c|c|c|}
\hline AMOSTRA & Bi & Th & U \\
\hline & $p p m$ & $p p m$ & $p p m$ \\
\hline CA-01 & 0.3 & 9.6 & 1.7 \\
\hline CA-11 & 0.4 & 13.4 & 2.8 \\
\hline CA-18 & -0.2 & 9.1 & 1.4 \\
\hline CJ-01 & -0.2 & 0.4 & 0.1 \\
\hline CJ-02 & -0.2 & 0.5 & 0.1 \\
\hline CJ-03 & -0.2 & 0.6 & 0.4 \\
\hline CJ-04 & -0.2 & 0.8 & 2.1 \\
\hline CJ-06 & -0.2 & 9.2 & 1.6 \\
\hline CJ-07 & -0.2 & 1.5 & 0.4 \\
\hline ET-54-2 & -0.2 & 19.2 & 2.8 \\
\hline ET-54-2 REP & -0.2 & 19.9 & 2.8 \\
\hline ET-54-3 & -0.2 & 29.1 & 3.9 \\
\hline ET-54-4 & 0.3 & 24.0 & 3.8 \\
\hline ET-54-6 & -0.2 & 22.6 & 3.9 \\
\hline ET-54-7 & -0.2 & 27.0 & 4.9 \\
\hline ET-54-8 & -0.2 & 22.1 & 3.6 \\
\hline ET-54-10 & -0.2 & 23.7 & 3.2 \\
\hline ET-54-11 & -0.2 & 19.8 & 3.6 \\
\hline ET-64B & 0.3 & 25.7 & 4.0 \\
\hline NC-088 & -0.2 & 2.8 & 1.1 \\
\hline NC-23 & -0.2 & 0.7 & 0.3 \\
\hline PA-15 & -0.2 & 16.2 & 3.9 \\
\hline VS-01 & 0.3 & 13.4 & 4.9 \\
\hline VS-02 & 0.3 & 12.8 & 3.3 \\
\hline VS-03 & 0.3 & 13.4 & 4.2 \\
\hline VS-04 & -0.2 & 13.0 & 4.2 \\
\hline VS-06 & 0.2 & 12.9 & 3.7 \\
\hline VS-09 & 0.2 & 13.0 & 3.9 \\
\hline VS-09 REP & 0.3 & 12.7 & 3.8 \\
\hline VS-11 & 0.4 & 13.5 & 2.7 \\
\hline VS-12 & 0.3 & 13.6 & 4.4 \\
\hline VS-13 & 0.3 & 13.2 & 3.5 \\
\hline
\end{tabular}

